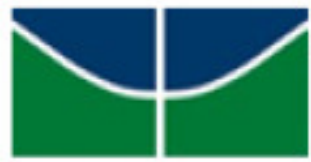

UNIVERSIDADE DE BRASÍLIA

FACULDADE DE ECONOMIA, ADMINISTRAÇÃO E CONTABILIDADE - FACE PROGRAMA DE PÓS-GRADUAÇÃO EM ADMINISTRAÇÃO - PPGA

FERNANDA BUENO CARDOSO SCUSSEL

DIGA-ME QUEM ÉS E TE DIREI SE ME RELACIONAREI COM VOCÊ: A INFLUÊNCIA DA PERSONALIDADE DE MARCA COM CLIENTES NO MERCADO DE MODA FEMININA DE LUXO

BRASÍLIA/DF 
Fernanda Bueno Cardoso Scussel

DIGA-ME QUEM ÉS E TE DIREI SE ME RELACIONAREI COM VOCÊ: A INFLUÊNCIA DA PERSONALIDADE DE MARCA COM CLIENTES NO MERCADO DE MODA FEMININA DE LUXO

Dissertação submetida ao Programa de Pós-Graduação em Administração da Universidade de Brasília como requisito parcial para a obtenção do grau de Mestre em Administração.

Orientadora: Prof. Dra. Gisela Demo 


\title{
DIGA-ME QUEM ÉS E TE DIREI SE ME RELACIONAREI COM VOCÊ: A INFLUÊNCIA DA PERSONALIDADE DE MARCA COM CLIENTES NO MERCADO DE MODA FEMININA DE LUXO
}

\author{
Dissertação submetida ao Programa de Pós-Graduação em \\ Administração da Universidade de Brasília como requisito \\ parcial para a obtenção do grau de Mestre em Administração. \\ Área de Concentração: Inovação e Estratégia
}

Aprovado em

Profa. Dra. Gisela Demo

Orientadora (Universidade de Brasília - PPGA/UnB)

\begin{abstract}
Profa. Dra. Aurea de Fátima Oliveira
Examinador Externo (Universidade Federal de Uberlândia - UFU/MG)
\end{abstract}

Prof. Dr. Tomás de Aquino Guimarães

Examinador Interno (Universidade de Brasília - PPGA/UnB)

Profa. Dra. Solange Alfinito

Examinador Interno (Universidade de Brasília - PPGA/UnB) - Suplente 
Dedico este trabalho ao Diogo, meu amado esposo... Razão para as minhas emoções, a calma das minhas tempestades, a fé para as minhas dúvidas, a paz das minhas confusões. Este trabalho também é seu! 


\section{AGRADECIMENTOS}

Em primeiro lugar, agradeço a Deus por ter escutado minhas orações. Só Ele sabe o quanto eu pedi por este mestrado, o quanto eu desejei estar aqui hoje e o que ele significa para mim. Agradeço por Ele ter me colocado onde eu precisava estar e por todos os ensinamentos deste período intenso em tantos sentidos que foi o mestrado.

À minha mãe, Iracema, meu maior modelo de fé e coragem, de luta, de não se abalar frente às adversidades da vida. Obrigada por ter me feito uma mulher forte, por ter me ensinado a sempre me questionar, mas nunca duvidar de mim mesma. Sei que, onde você estiver, estará orgulhosa de mim, meu anjo. Ao meu pai, João Roque, o coração mais generoso que eu já conheci, obrigada pelo exemplo de trabalho duro, de perseverança, de doação e de humildade. Meu pai, não há nada que me encha mais de alegria do que te ver orgulhoso de mim. Obrigada por serem essa mistura perfeita de austeridade e simplicidade, por me ensinarem desde sempre o valor da educação e por terem me criado para o mundo, mas especialmente por terem me dado raízes que me fazem sempre querer voltar.

Agradeço aos meus irmãos, Alexandre, Carla e Maurício, pela torcida fiel e por sempre acreditarem em mim, por sempre me encherem de mimos e de coragem. Em especial, minha irmã Carla, minha melhor amiga, não há palavras que expliquem o quanto eu sou grata por ter você! Este trabalho é um pouco seu, pois é a sua crença de que eu sou a pessoa mais inteligente do mundo (rs!) que me faz ter vontade de ser melhor.

Um obrigada do tamanho do mundo ao meu marido Diogo, pelo apoio incondicional em todos os meus projetos, especialmente no mestrado. Obrigada por me acalmar, me questionar, me encorajar, me fazer enfrentar meus medos e por sempre ter acreditado em mim naqueles momentos em que até eu tinha perdido a fé. Sou grata à vida simples, deliciosa e amorosa que tenho ao seu lado. Obrigada por sonhar e realizar junto comigo!

Agradeço à minha sogra Bernadete pelas incansáveis orações, minha prima Nisandra pelo colo sempre disponível (mesmo que via whatsapp) e à minha grande amiga Nicole Spohr, por compartilhar comigo a paixão pela pesquisa e ser tão inspiradora, questionadora e solícita.

Agradeço às minhas amigas Robertha Figueiredo e Fernanda Domareski e suas famílias iluminadas, por sempre abrirem as portas de suas casas quando precisei, por terem abraçado a minha pequena família como se fosse a de vocês. Só quem está longe dos seus sabe o valor de encontrar família nos amigos. Eu nunca vou esquecer. Vocês fizeram a minha Brasília muito mais feliz. 
Agradeço à minha dedicada e competente orientadora Gisela Demo, por todos os ensinamentos, que foram muito além desta dissertação. Obrigada por compartilhar a paixão pelo ensino e pela pesquisa. Obrigada por cuidar deste trabalho como se fosse seu e por acreditar no meu potencial de fazer um trabalho muito mais complexo do que eu imaginava ser capaz. Objetiva, perspicaz, incansável, presente e acessível - e tudo isso em cor-de-rosa! Obrigada por ser este exemplo de profissional tão consistente, que me inspira muito mais do que podes imaginar. É uma honra ser a sua primeira orientação de mestrado. Gisela, ter você como orientadora é um luxo!!!

Agradeço às gentis palavras do Prof. Tomás de Aquino e da Prof. Áurea Oliveira em meu exame de qualificação, cujas colaborações vão muito além das provocações que ajudaram aquele projeto a se tornar esta dissertação. Ser avaliada por dois grandes mestres é uma honra, e esta oportunidade certamente me instigou a construir um trabalho melhor. Agradeço, ainda, a todos os professores do PPGA, por fazerem da UnB esta instituição forte da qual eu tenho muito orgulho de fazer parte. Vocês mudaram o meu mundo!

A todas as entrevistadas desta pesquisa, agradeço o tempo e a confiança depositada em mim. Além de permitirem a minha coleta de dados, me permitiram refletir, rever muitos preconceitos e, por que não, sonhar? (rs!). A todos os avaliadores da análise de juízes, pessoas pelas quais tenho imenso respeito e admiração, obrigada por dedicarem tempo ao meu trabalho e pelas valiosas contribuições. A todos aqueles responderam e que me ajudaram a compartilhar o questionário, que mandaram pra Deus e o mundo, que permitiram meu acesso a seus locais de trabalho... obrigada, obrigada, obrigada! Quando eu achava que não conseguiria atingir, sempre surgia uma amiga para renovar meu fôlego. Ainda, um obrigada muito especial à Prof. Jaqueline Keller e toda sua ajuda em todas as etapas do meu mestrado, desde o projeto de pesquisa. Todos estes acontecimentos me fazem acreditar que os relacionamentos e o cultivo deles são as coisas mais valiosas que vemos na vida!

Aos amigos do PPGA, obrigada por terem tornado essa caminhada mais tranquila. Obrigada pela ajuda sempre disponível, pelos almoços, por compartilharem o conhecimento enorme de vocês e até mesmo pelo divertido grupo de Whatsapp, que certamente tornou este período mais leve e divertido. Sinto muito orgulho de ter estudado com vocês!

Obrigada, ainda, a todos os funcionários do PPGA, especialmente à querida Edvânia, que chegou aos 45 do segundo tempo e mudou a nossa secretaria! Obrigada pela boa vontade, pela dedicação e por sempre estar disponível. Você não tem ideia do quanto me ajudou e eu serei sempre muito grata! 
A lista de agradecimentos é grande e eu a encerro tendo a certeza do quanto sou iluminada a abençoada. Um filme passou na minha mente. Obrigada meu Deus, novamente, por estes dois anos angustiantes, produtivos e incríveis de mestrado. Obrigada pelo sentimento de estar exatamente onde eu queria estar. Definitivamente, isto não tem preço. 


\section{RESUMO}

Com o imperativo da competitividade no cenário organizacional e com a exigência cada vez maior de atendimento e produtos customizados por parte dos clientes, especialmente no segmento de marcas de luxo, as organizações procuram cada vez mais excelência em suas estratégias empresariais. Entre elas, o desenvolvimento do relacionamento entre marcas e clientes, por meio do marketing de relacionamento ou CRM (Customer Relationship Management) recebe conotação especial, por se traduzir em profícua fonte de diferenciação competitiva. Neste contexto, a personalidade atribuída à marca orienta a preferência e o consumo por parte das clientes, constituindo-se no ponto de partida para os consumidores articularem o seu relacionamento com ela. Assim, o estudo do relacionamento entre clientes e marcas de moda feminina de luxo é pertinente, uma vez que estão inseridas em um cenário de alta competitividade e com forte potencial de desenvolvimento no contexto brasileiro. Destarte, como objetivo geral, buscou-se avaliar a relação entre a personalidade de marcas de moda feminina de luxo atribuídas pelas clientes e a percepção de seu relacionamento com tais marcas. Trata-se de um estudo de natureza multimétodo, utilizando entrevistas e aplicação de questionário. Os resultados foram analisados por meio de análise de conteúdo categorial temática, análise fatorial exploratória e confirmatória, e análise de caminhos, por meio da modelagem por equações estruturais. Como contribuições, pode-se destacar o desenvolvimento e validação de uma escala de CRM em um setor pouco explorado pela literatura de marketing de relacionamento. A versão final da escala ficou composta por três fatores, quais sejam, fidelização, experiência com a marca e imagem da marca, apresentando validade interna, de conteúdo e confiabilidade. Por fim, o modelo estrutural apresentou um bom ajuste confirmando a influência da personalidade de marca, especialmente da credibilidade e da sofisticação, sobre a percepção de relacionamento, o que faz todo sentido no mercado de luxo. Como contribuição gerencial, os resultados podem ser usados como diagnóstico para os gestores do setor trabalharem a identidade de suas marcas a fim de otimizar o relacionamento com suas clientes e obter melhores resultados organizacionais. Limitações e sugestões para estudos futuros são discutidas.

Palavras-chave: marketing de relacionamento (CRM); personalidade de marca; mercado de moda feminina de luxo; validação exploratória e confirmatória de escala; modelagem por equações estruturais. 


\section{ABSTRACT}

With the imperative of competitiveness in the organizational setting and with the increasing demand for customized services and products by customers, especially in the luxury segment brands, organizations increasingly seek excellence in their business strategies. Among them, the development of the relationship between brands and customers through the customer relationship management or CRM (Customer Relationship Management) plays a special role as an effective source of competitive differentiation. In this context, the personality assigned to a brand guides its consumption by the clientes, constituting the starting point for consumers articulate their relationship with it. Therefore, the study of the relationship between clients and luxury women's fashion brand is relevant, since they operate in a highly competitive scenario, with strong development potential in the Brazilian context. Thus, the main objective of this study was to evaluate the relationship between the personality of luxury women's fashion brands assigned by customers and the perception of their relationship with such brands. The study is multi-method, using interviews and questionnaire. The results were analyzed using thematic content analysis, exploratory and confirmatory factor analysis, and path analysis, through structural equation modeling. As contributions, we may highlight the development and validation of a CRM scale in a sector little explored in the relationship marketing literature. The final version of the scale was made up of three factors, namely loyalty, brand experience and brand image, presenting internal validity, contente validity and reliability. Finally, the structural model presented a satisfactory adjustment, confirming the influence of brand personality, especially credibility and sophistication, on the perception of relationship, which makes sense in the luxury market. As managerial implications, the results can be used as a diagnostic for managers in the luxury sector to work the identity of its brands in order to optimize the relationship with their clients and achieve better business results. Limitations and suggestions for further studies are discussed.

Keywords: customer relationship management (CRM); brand personality; luxury fashion brands; exploratory and confirmatory factor analysis; structural equation modeling. 


\section{LISTA DE ILUSTRAÇÕES}

\section{LISTA DE FIGURAS}

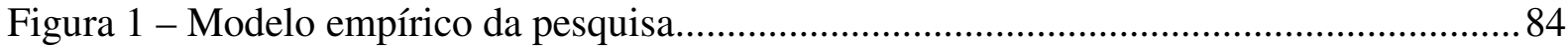

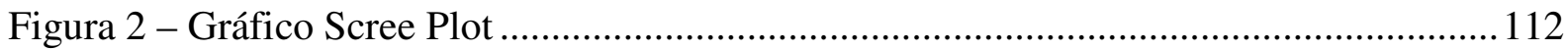

Figura 3 - Representação da estrutura fatorial obtida ...................................................... 115

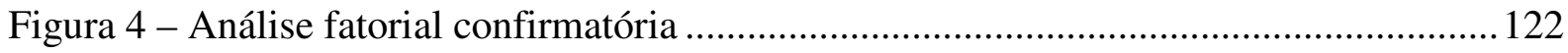

Figura 5 - Resultado da path analysis para o modelo proposto ............................................. 136

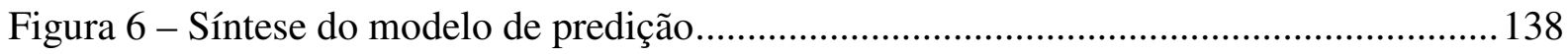

\section{LISTA DE GRÁFICOS}

Gráfico 1 - Artigos sobre CRM publicados nos periódicos selecionados ….......................... 70

Gráfico 2 - Artigos sobre CRM publicados entre 2010 e 2015 ........................................... 71

Gráfico 3 - Enquadramento dos artigos sobre CRM............................................................. 71

Gráfico 4 - Instituição de origem dos autores que publicaram sobre CRM.............................72

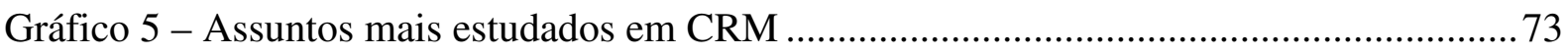

Gráfico 6 - Natureza dos artigos teórico-empíricos sobre CRM ............................................ 73

Gráfico 7 - Ramo de atuação das empresas pesquisadas ..................................................... 74

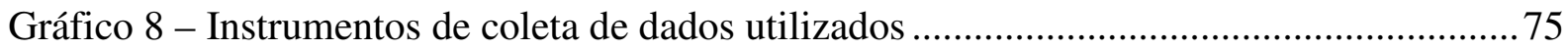

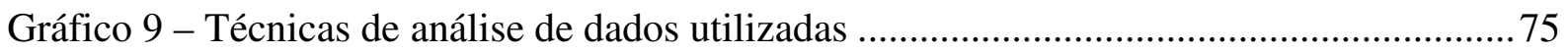

Gráfico 10 - Áreas de concentração dos grupos de pesquisa....................................................78

Gráfico 11 - Grupos de pesquisa sobre Marketing de Relacionamento, Gestão do

Relacionamento com Clientes ou CRM por ano de criação.................................................. 81

Gráfico 12 - Evolução da produção C, T \& A dos grupos de pesquisa sobre Marketing de

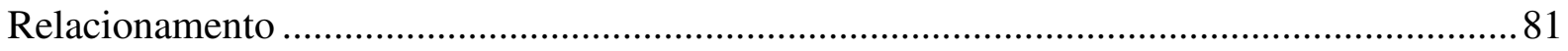

Gráfico 13 - Evolução da produção C, T \& A dos grupos de pesquisa sobre CRM................82

Gráfico 14 - Crescimento do mercado de luxo entre 1995 e 2012 ( $€$ bilhões) ......................... 87

Gráfico 15 - Crescimento do mercado de luxo no Brasil entre 2006 e 2012 (R \$ bilhões) ...... 88

Gráfico 16 - Grau de escolaridade das participantes do Estudo 1 ......................................95

Gráfico 17 - Tempo de relacionamento das participantes do Estudo $1 \mathrm{com}$ as marcas

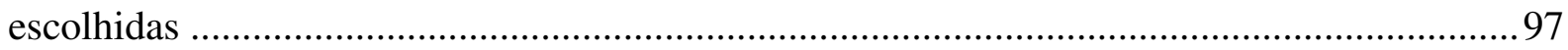

Gráfico 18 - Frequência de compra das participantes do Estudo 1........................................97

Gráfico 19 - Grau de escolaridade das participantes do Estudo 2 ........................................98

Gráfico 20 - Tempo de relacionamento das participantes do Estudo 2 com as marcas

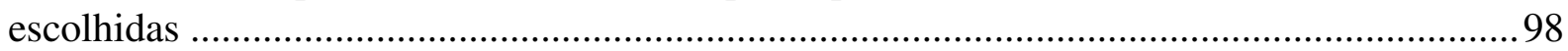

Gráfico 21 - Frequência de compra das participantes do Estudo 2 ......................................99

Gráfico 22 - Grau de escolaridade da amostra total......................................................... 100

Gráfico 23 - Tempo de relacionamento das participantes com as marcas escolhidas ........... 100

Gráfico 24 - Frequência de compras das participantes do estudo.......................................... 102

Gráfico 25 - Média das dimensões de Personalidade de Marca para as marcas de moda feminina de luxo mais citadas pelas participantes................................................................. 126 
Gráfico 26 - Frequência relativa dos itens do fator Experiência com a Marca...................... 131

Gráfico 27 - Frequência relativa dos itens do fator Fidelização de Clientes ......................... 132

Gráfico 28 - Frequência relativa dos itens do fator Imagem da Marca ............................... 134

\section{LISTA DE QUADROS}

Quadro 1 - Escala de Dimensões de Personalidade de Marca...................................................37

Quadro 2 - Escala de Dimensões de Personalidade de Marca no Contexto Brasileiro ............45

Quadro 3 - Comparação entre as dimensões de personalidade de marca no Brasil e em outros

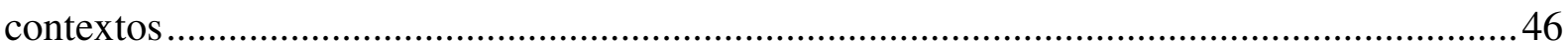

Quadro 4 - Categorização dos artigos de Personalidade de Marca ........................................ 51

Quadro 5 - Distribuição dos grupos de pesquisa sobre Marketing de Relacionamento, Gestão

por Relacionamento ou CRM por unidade da federação e instituição ....................................79

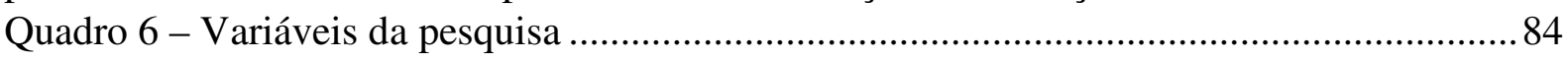

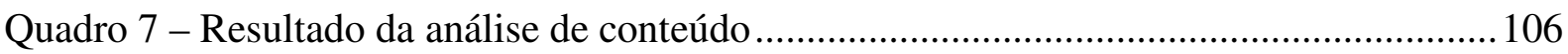

Quadro 8 - Validade de Conteúdo da ERC Luxo .................................................................. 119

\section{LISTA DE TABELAS}

Tabela 1 - Lista de periódicos selecionados em Administração ..............................................48

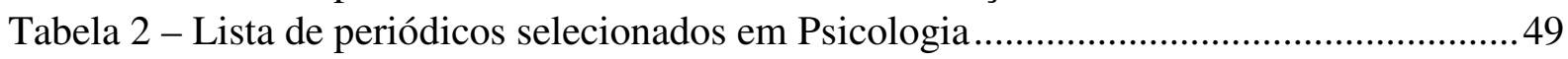

Tabela 3 - Comparação entre as ERC brasileira e ERC americana ...........................................69

Tabela 4 - Autores que mais publicaram entre 2010 e 2015 ................................................... 72

Tabela 5 - Número de pesquisadores, formação e nacionalidade ............................................. 82

Tabela 6 - Resultados da Análise Paralela ........................................................................... 113

Tabela 7 - Matriz de Correlação entre os 3 fatores ............................................................. 113

Tabela 8 - Conteúdo avaliado pelos fatores de primeira ordem em suas cargas fatoriais ..... 114

Tabela 9 - Coeficientes alfa $(\alpha)$ e o número de itens para os fatores extraídos ..................... 116

Tabela 10 - Índices psicométricos da versão completa da ERC Luxo...................................117

Tabela 11 - Índices de ajuste da análise confirmatória ...................................................... 121

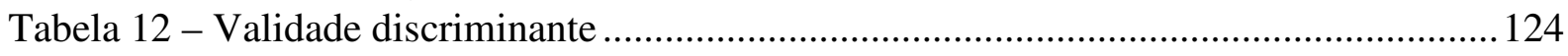

Tabela 13 - Média, desvio padrão e moda das variáveis de personalidade atribuídas às marcas de moda feminina de luxo mais citadas .......................................................................... 125

Tabela 14 - Média e desvio padrão das variáveis de personalidade atribuídas às marcas de

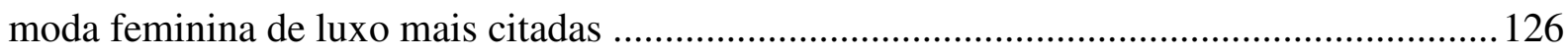

Tabela 15 - Visão geral da percepção de relacionamento................................................ 129

Tabela 16 - Visão geral da percepção dos clientes a respeito da Experiência com a Marca.130

Tabela 17 - Visão geral da percepção dos clientes a respeito da Fidelização de Clientes..... 132

Tabela 18 - Visão geral da percepção das clientes a respeito da Imagem da Marca .............. 133

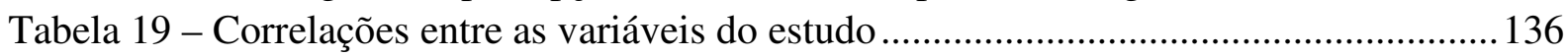

Tabela 20 - Índices de adequação do modelo testado....................................................... 137 


\section{SUMÁRIO}

1 INTRODUÇÃO ........................................................................................................................14

2 REFERENCIAL TEÓRICO ........................................................................................24

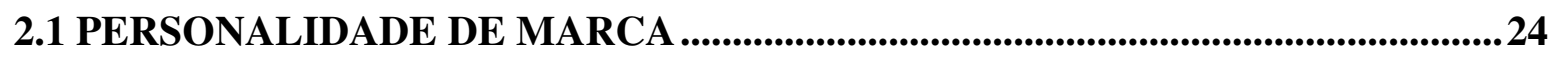

2.1.1 Personalidade de Marca: Estado da Arte.................................................................24

2.1.2 Personalidade de Marca: Revisão da Produção Nacional ...........................................4

2.1.3 Institucionalização da Pesquisa em Personalidade de Marca.....................................53

2.2 MARKETING DE RELACIONAMENTO (CRM)..................................................55

2.2.1 Marketing de Relacionamento: Estado da Arte....................................................55

2.2.2 Marketing de Relacionamento (CRM): Revisão da Produção Nacional....................69

2.2.3 Institucionalização da Pesquisa em CRM ................................................................

3 MODELO DA PESQUISA ........................................................................................................84

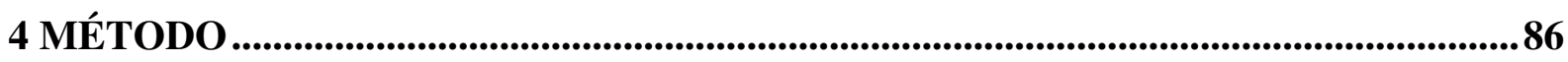

4.1 TIPO E DESCRIÇÃO GERAL DA PESQUISA ..........................................................86

4.2 CARACTERIZAÇÃO DO SETOR .........................................................................87

4.3 ESTUDO QUALITATIVO ...............................................................................90

4.3.1 População e amostra............................................................................................... 90

4.3.1.1 Caracterização da amostra .................................................................................91

4.3.2 Instrumento de pesquisa ..................................................................................91

4.3.3 Procedimentos de coleta, tratamento e análise de dados............................................91

4.4 ESTUDO QUANTITATIVO .........................................................................................92

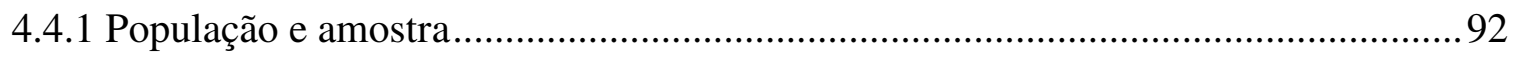

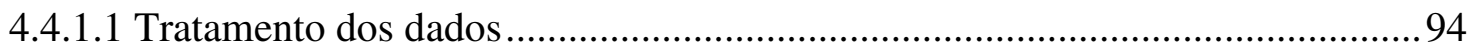

4.4.1.2 Caracterização da amostra .............................................................................95

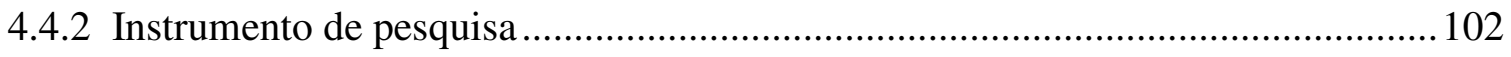

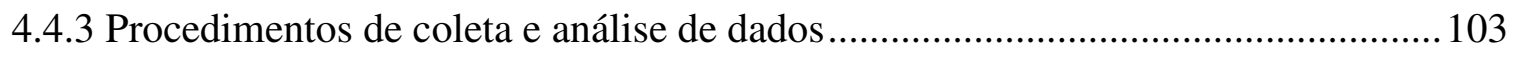

5 RESULTADOS E DISCUSSÃO ............................................................................105

5.1 Estudo Qualitativo ..........................................................................................................105

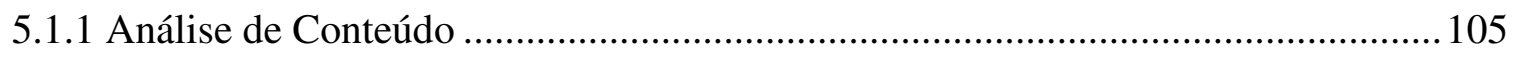

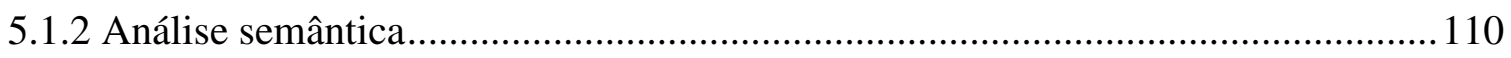

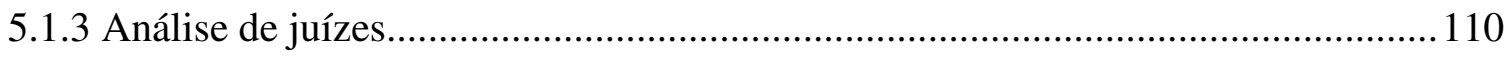

5.2 Estudo Quantitativo..................................................................................................................111 
5.2.1 Estudo 1: Validação Exploratória da ERC Luxo

5.2.2 Estudo 2: Validação Confirmatória da ERC Luxo.

5.2.3 Identificação da personalidade atribuída às marcas de moda feminina de luxo .... 124

5.2.4 Identificação da Percepção de Relacionamento com marcas de moda feminina de luxo.

5.2.5 Verificação do ajuste do modelo global entre personalidade de marca e percepção de relacionamento com o cliente

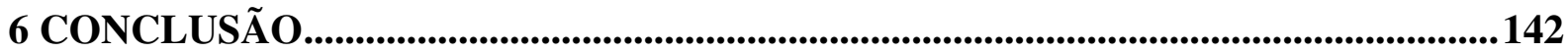

6.1 Síntese dos Principais Resultados............................................................................................ 142

6.2 Contribuições Acadêmicas e Gerenciais .................................................................................143

6.3 Limitações e Recomendações para Estudos Futuros..................................................144

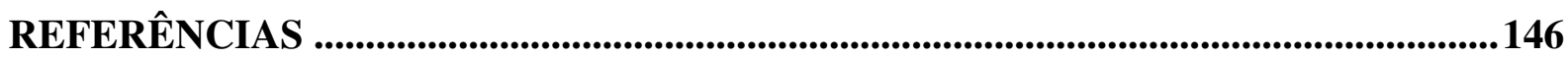

Apêndice A - Roteiro de Entrevista...............................................................................178

Apêndice B - Termo de consentimento para entrevista ....................................................179

Apêndice C - Instrumento de Pesquisa (Estudo Quantitativo)...........................................181 


\section{INTRODUÇÃO}

Por conta da globalização e das novas tecnologias, a competitividade passa a ser imperativa para as organizações, que precisam buscar alternativas de diferenciação competitiva. Assim, é importante considerar, nos estudos organizacionais, o contexto de competitividade recrudescente (DEMO, 2014).

Coyne (1986) defende que a vantagem competitiva está relacionada à percepção dos consumidores, que devem perceber uma diferença consistente em atributos considerados importantes entre um produto ou serviço de uma organização e os de seus concorrentes. Segundo Hoffman (2000), existem dois tipos de ativos de mercado que podem levar a vantagens competitivas sustentáveis: o relacional, que engloba os vínculos entre a organização e os consumidores; e o intelectual, que consiste no conhecimento sobre as preferências do mercado. Neste sentido, defende-se que o marketing de relacionamento ajuda as empresas a gerenciarem de maneira efetiva os diversos segmentos de mercado e, especificamente, as interações com os consumidores para manter a competitividade (MISHRA; MISHRA, 2009).

Posto isto, tem-se que a segmentação de mercado permite a definição de ofertas que melhor satisfaçam clientes específicos, canalizando esforços e capital para segmentos potencialmente mais lucrativos (GALHANONE; TOLEDO, 2008). Entre estes últimos, encontra-se o segmento dos produtos de luxo, altamente relacionados com qualidade e reconhecimento social, destinados a uma classe social mais privilegiada e fiel (CASTARÈDE, 2005; ALLÉRÈS, 2006).

A palavra luxo tem origem do latim luxus, que se relaciona à abundância e ao refinamento (CASTARÈDE, 2005). Para o autor, o termo apresenta-se como um conceito variável e passível de mudanças, dependendo do momento histórico a que se refere, ainda que três constantes façam parte do que se entende por luxo: oferenda, identidade e preciosidade. Visto que o conceito de luxo é variável, com o passar dos tempos, o luxo tornou-se uma cultura psicológica, com a valorização de sensações subjetivas, onde os indivíduos passam a buscar produtos e serviços que não apenas satisfaçam suas necessidades básicas, mas também suas necessidades emocionais (LIPOVETSKY; ROUX, 2005). Assim, observa-se que o luxo tem origem no julgamento de alguém sobre o valor de um objeto, e não do objeto em si (STREHLAU, 2008). Segundo a autora, ainda que sua definição possa se moldar ao contexto, o luxo consiste em algo desejado por muitos e obtido por poucos. 
Posto isto, a definição de produtos de luxo sugere bens de excelente qualidade e durabilidade, status de bom gosto e refinamento, preço alto, escassez e exclusividade, forte apelo estético, tradição, história e lenda (DUBOIS; LAURENT; CZELLAR, 2005). Destacase, também, que um produto de luxo é aquele que engloba um grupo de representações imagens, conceitos, sensações - que são compradas juntamente com o objeto (LIPOVETSKY; ROUX, 2005).

Devido ao caráter experiencial da natureza do consumo de luxo, o conceito de marca de luxo adquire um caráter subjetivo e amplamente dependente do ambiente cultural e social onde os consumidores vivem (VIGNERON; JOHNSON, 2004). O que a literatura reconhece, por sua vez, é que o consumo de luxo nos últimos anos tem mudado de um modelo de consumo tradicional para um modelo com base em relacionamentos, orientado para o novo indivíduo nesta nova sociedade de consumo, e que compreende o consumo como uma experiência holística e pessoal (ATWAL; WILLIAMS, 2009).

Dentro da perspectiva apresentada, ressalta-se, ainda, que o comportamento de consumo no mercado de luxo contradiz as regras do marketing de consumo de massa, sendo necessário adaptar e reinventar conceitos para obter resultados neste segmento (GALHANONE; TOLEDO, 2008). Desta forma, o marketing de relacionamento assume conotação especial, por representar uma mudança de paradigma do marketing transacional para o marketing focado na customização (DEMO; ROZZETT, 2013).

As informações sobre os clientes de produtos de luxo passam a constituir instrumento relevante para a construção e manutenção do relacionamento entre marca e cliente (NUENO; QUELCH, 1998). Nesta perspectiva, Allérès (2006) defende que as estratégias de marketing direcionadas aos produtos de luxo exigem o conhecimento do que o consumidor espera, enquanto Castaréde (2005) discorre sobre a expectativa do consumidor de luxo em ser tratado de forma customizada, como cliente especial.

O luxo tornou-se um mercado extremamente relevante para muitos países, devido ao volume de negócios que movimenta e ao seu potencial de crescimento e geração de empregos (CASTARÈDE, 2005). Segundo De Sá e Marcondes (2010), o mercado mundial de produtos de luxo tem atingido cada vez mais consumidores, revelando um crescimento significativo em todo o mundo. No Brasil, este segmento encontra um terreno fértil para seu crescimento, por conta das dimensões do país, que representam um volume de consumidores de mercado de luxo superior ao encontrado em países estrangeiros (STREHLAU; ARANHA, 2004). Além disso, é preciso considerar que outras classes econômicas, anteriormente não consideradas 
público-alvo de marcas de luxo, estão atuando como consumidoras de produtos de luxo no país (STREHLAU, 2008). Este fato pode estar relacionado à facilidade de crédito que o consumidor brasileiro encontra, o que pode representar o principal acesso às marcas de luxo no país (PIANARO; MARCONDES, 2008). Os autores sustentam, ainda, que entre $70 \%$ e $80 \%$ das compras de produtos de vestuário e acessórios de luxo no Brasil foram realizadas por meio de pagamentos parcelados, o que se revela como um fator cultural e, ao mesmo tempo, uma vantagem competitiva em relação a lojas em outros países.

Há de se ressaltar, ainda, a bem-vinda evolução do papel da mulher na sociedade de consumo, com a observação do aumento do poder de compra das mulheres nos últimos anos (TRUONG; McCOLL; KITCHEN, 2009). No consumo de produtos de luxo, o público feminino apresenta-se responsável pela aquisição de mais da metade do volume comercializado no país (LEITE, 2014). A autora aponta que as consumidoras brasileiras de luxo adquirem marcas deste segmento no país devido à comodidade, condições de pagamento, ainda que a um custo maior, quando comparadas à compra realizada no exterior. Admite-se, desta forma, a consideração do público feminino na definição de estratégias do mercado de luxo como uma fonte de vantagem competitiva para as empresas (TRUONG; McCOLL; KITCHEN, 2009). Esta colocação é reforçada por Leite (2014), ao apontar a necessidade de direcionamento dos investimentos na construção de relacionamentos com as consumidoras de luxo.

O mercado de luxo na moda, por sua vez, refere-se a itens do vestuário de alta costura e de roupas de grife, contemplando, ainda, acessórios como cintos, bolsas, sapatos, óculos, relógios e perfumes (BRAGA, 2004). Cabe salientar que os produtos de vestuário, composto por trajes e acessórios, constituem mais de $25 \%$ do total do faturamento mundial com produtos de moda de luxo (CASTARÈDE, 2005).

Diante deste cenário, considerou-se contributivo focar o mercado de moda feminina de luxo, ainda inexplorado em pesquisas de marketing de relacionamento, tendo como objeto de pesquisa as marcas de moda feminina de luxo. Na tentativa de conceituar tal objeto, observouse que não há consenso entre os pesquisadores sobre uma definição para marcas de luxo, especialmente devido à falta de um conceito robusto para o que constitui um produto de luxo (SUNG; CHOI; AHN; SONG, 2015). Destarte, considerando a necessidade de uma definição capaz de abarcar os itens de vestuário sugeridos por Braga (2004), o fator subjetivo e contextual oriundo da realidade do consumidor (VIGNERON; JOHNSON, 2004), a relevância do julgamento de cada indivíduo sobre o objeto (STREHLAU, 2008) e, com isto, a 
elasticidade característica do conceito de luxo, para fins desta pesquisa, define-se marcas de moda feminina de luxo como as marcas de itens do vestuário feminino, a saber, roupas e acessórios, percebidas como marcas de luxo pela consumidora.

Visto que os produtos de luxo alcançam o consumidor principalmente pela representatividade conquistada no imaginário dos indivíduos (LIPOVETSKY; ROUX, 2005), tem-se que as marcas apresentam tanta importância quanto o próprio produto: elas constituem um patrimônio (PIANARO; MARCONDES, 2010). Para os consumidores, as marcas servem à simplificação da escolha pela promessa de um determinado nível de qualidade, pela redução de riscos e pela geração de confiança (KELLER; LEHMANN, 2006). Ainda, as marcas cumprem a função de identificar a origem ou o fabricante de um produto, sendo que, através delas, é possível que os consumidores avaliem um produto idêntico de forma diferenciada, de acordo com o posicionamento da marca (KOTLER; KELLER, 2012).

Neste sentido, uma marca de luxo posiciona-se pela alta qualidade dos seus produtos, além de ser reconhecida mundialmente por representar produtos de alto valor e de estilo inimitável (LIPOVETSKY; ROUX, 2005). Não obstante, além de qualidade e reconhecimento inquestionáveis, uma marca de luxo deve abarcar exclusividade, manutenção das vendas e, mormente, lealdade dos consumidores (PHAU; PRENDERGAST, 2000).

No que se refere à construção de marcas fortes e capazes de reter clientes, Demo e Ponte (2008) discutem a necessidade de as organizações obterem maior participação na mente (share of mind) e no coração dos clientes (share of heart), estabelecendo com eles relacionamentos de longo prazo ou relacionamentos lucrativos. Aplicando-se este pressuposto ao contexto de marcas de luxo, tem-se que estas devem promover constantemente um forte esforço de posicionamento, uso criativo de ferramentas de marketing, oferecendo excelência no atendimento e renovação contínua sem que se perca a essência da marca. Salienta-se, ainda, que as marcas líderes no segmento de luxo são aquelas que foram capazes de compreender as motivações e os desejos do consumidor, por meio da criação de imagens relevantes e cativantes para o seu produto (KOTLER; KELLER, 2012). Segundo os autores, através da busca pela diferenciação, estas marcas conectam-se melhor com os consumidores, promovendo maior fidelidade e subsequente poder de determinação de preço.

Para Keller e Lehmann (2006), a superioridade competitiva originar-se-á na capacidade de as marcas estabelecerem associações nas mentes dos consumidores, por meio de aspectos intangíveis da marca, que transcendem os atributos físicos do produto. Neste contexto, a marca deve ter componentes racionais e emocionais, sensibilizando tanto a mente 
quanto o coração dos clientes, entrando em cena o branding emocional (inserção de conteúdo emotivo, em adição ao conteúdo racional, capaz de criar sintonia emocional com os clientes) e o marketing de experiências, onde sensações são trabalhadas pela empresa utilizando os cinco sentidos para um maior envolvimento do consumidor com a marca (KOTLER; KELLER, 2012). Há de se ressaltar que os componentes emocionais consistem em atributos intangíveis, que englobam pensamentos, sentimentos, percepções, imagens e experiências que se relacionam com a marca na mente dos consumidores (KELLER, 2009).

Na mesma linha, o marketing de experiência, em oposição ao marketing transacional com clientes que tomam decisões puramente racionais focando funcionalidade e benefícios, aborda os consumidores como seres racionais e emocionais que buscam experiências de compra prazerosas (SCHMITT, 1999). Por conseguinte, o autor propõe um modelo com cinco diferentes tipos de experiências que os especialistas em marketing podem trabalhar com seus clientes, quais sejam, experiências sensoriais (perceber); experiências afetivas (sentir); experiências cognitivas criativas (pensar); experiências físicas, comportamentos e estilos de vida (agir); e experiências de identidade social, resultantes da interação com um grupo de referência ou cultura (relacionar-se). Sob esta perspectiva, Atwal e Williams (2009) acrescentam que, para o marketing de marcas de luxo, a experiência é fundamental.

Posto isso, observa-se que o conceito de marketing, como o conjunto de atividades, instituições e processos para criar, comunicar, distribuir e efetuar a troca de ofertas que tenham valor para consumidores, clientes, parceiros e a sociedade como um todo (AMERICAN MARKETING ASSOCIATION, 2013) corrobora o cenário descrito para as marcas de luxo. Neste sentido, ressalta-se que a marca não compõe um objeto passivo das transações de marketing, mas sim um elemento ativo, capaz de contribuir para a construção do relacionamento com o consumidor (FOURNIER, 1998). Uma marca consiste em um nome e/ou símbolo distintos, com o objetivo de permitir a identificação dos bens ou serviços de um vendedor ou de um grupo de vendedores e a diferenciar esses bens e serviços daqueles dos concorrentes (AAKER, 1998). Dentro deste pressuposto, assume-se que não é suficiente apenas conquistar clientes, mas sim retê-los (DEMO; ROZZETT, 2013). Na busca da construção de um relacionamento duradouro com os consumidores, de forma a mantê-los satisfeitos e manter o constante mapeamento de seus desejos e necessidades para transformálos em ferramentas de mudança nas estratégias de marketing, surge o CRM (Customer Relationship Management ou Gestão do Relacionamento com o Cliente). 
O CRM impõe às organizações a necessidade de gerenciar o relacionamento que se tem com os clientes em nome da vantagem competitiva ao fornecer oportunidades de utilizar informações, conhecer e atender melhor os clientes, oferecer valor por meio de ofertas customizadas e desenvolver relacionamentos duradouros (PAYNE, 2006). Neste contexto, o autor destaca que o CRM, para ser bem-sucedido, precisa estar imbuído de visão estratégica para agregar valor ao acionista, por meio do desenvolvimento de relacionamentos com clientes estratégicos, unindo o potencial da tecnologia da informação (TI) às estratégias e pressupostos do marketing de relacionamento. Assim, neste trabalho, os termos CRM e marketing de relacionamento serão usados indistintamente. Em outras palavras, Payne (2006) considera que o CRM pode ser conceituado como uma abordagem estratégica e holística de gestão do relacionamento com os clientes para criar valor para os acionistas. Na mesma linha, Vavra (1993) argumenta que o marketing de relacionamento compreende aspectos de qualidade, prestação de serviços excelentes aos clientes e estratégias de pós-marketing, ou fidelização.

Na visão de Giglio (2010), o consumidor consiste no ponto de partida para o processo de criação e produção das empresas. Isto pressupõe uma orientação para o mercado, onde as informações oriundas de todas as interações com clientes e potenciais clientes configuram um valioso ativo organizacional. Por conseguinte, é necessário acessar quais experiências e impressões apresentam maior influência nas decisões de compra do consumidor (KELLER, 2009). Neste sentido, o autor sugere que as atividades de marketing devem estar integradas de forma a passar uma mensagem consistente ao consumidor em todas as interações com a empresa.

Tem-se então a gestão do CRM, capaz de monitorar e gerenciar a aquisição de informações valiosas através do relacionamento com clientes, permitindo entender e prever comportamentos, adequando as ofertas aos mesmos e facilitando o posicionamento da organização no mercado (DEMO, 2014). Desta forma, as empresas devem se concentrar na criação de vantagens ao cliente, entregando alto valor e satisfação, o que levará à repetição de compra e, finalmente, a uma alta rentabilidade para a empresa (KOTLER; KELLER, 2012).

Na perspectiva da construção de um relacionamento com os clientes, uma marca bemsucedida é aquela que caracteriza um relacionamento especial entre o consumidor e a organização (MCKENNA, 1999). Para Fournier (1998), uma das formas de se legitimar a marca como parceira do consumidor é evidenciar o modo através do qual as marcas são personalizadas ou ainda humanizadas. Assim, no intuito de identificar e mensurar o vínculo 
emocional e afetivo que as marcas têm com os clientes, surge o conceito de personalidade de marca, conjunto de características humanas associadas a uma marca (AAKER, 1997), que apresenta como consequência algumas importantes variáveis identificadas na literatura de marketing relacional: qualidade percebida da marca, atitude em relação à marca, intenção de comportamento futuro, ligação à marca, comprometimento com a marca e confiança na marca (MALIK; NAEEM, 2012).

A personalidade de marca confere profundidade, sentimentos e apreço na construção do relacionamento entre consumidor e marca, o que pode ser o alicerce para uma diferenciação real e uma vantagem competitiva (AAKER, 1996). Faz-se necessário, assim, a constante agregação de valor, o que requer o desenvolvimento de estratégias de marketing capazes de proporcionar à marca o diferencial necessário para competir no seletivo mercado de luxo.

A personalidade de marca reflete como as pessoas se sentem em relação a uma marca e, diferentemente dos atributos relacionados ao produto, serve a uma função simbólica (KELLER; LEHMANN, 2006), permitindo que uma relação mais forte seja construída entre marca e consumidor quando este percebe uma relação entre a sua identidade e a personalidade de uma marca (HANKINSON; COWKING, 1993). Partindo deste pressuposto, os consumidores não apenas perceberiam as marcas, mas também estariam dispostos a estabelecer relacionamentos com elas.

Dentro da perspectiva de luxo trabalhada, observa-se que atração e fidelização dos consumidores somente dar-se-ão a partir da satisfação de seus desejos e superação de expectativas antes da ação dos concorrentes. Para Fournier (1998), um relacionamento é baseado no seu significado e, assim, compreender determinado relacionamento requer o conhecimento dos significados que este fornece à pessoa. Segundo a autora, o relacionamento entre consumidor e marca se estabelece por meio da experiência vivida. Em outras palavras, a fidelização dos clientes será uma decorrência da oferta constante de experiências únicas e encantadoras ao público-alvo (DEMO, 2014).

Posto isso, tem-se que a personalidade da marca busca capturar a força da conexão entre consumidor e marca em direção à predição de um relacionamento duradouro. Não obstante, não foram encontrados estudos relacionando a personalidade de marca atribuída pelos clientes à percepção que eles têm do seu relacionamento com elas, apesar de a literatura sinalizar a possibilidade desta relação. Brito (2010), ao propor uma abordagem relacional ao valor da marca, realça que quando as marcas são encaradas como possuidoras de traços de 
caráter, os clientes têm maior probabilidade de se relacionarem com aquelas marcas com as quais sentem maior afinidade em termos de personalidade. $\mathrm{O}$ autor lembra que embora durante muitos anos as marcas tenham sido percebidas como elos entre os produtos/empresas e os seus clientes, esta perspectiva mudou significativamente, na medida em que as marcas são hoje entendidas como parceiras nos relacionamentos que se estabelecem com os consumidores.

Na mesma linha, Biel (1993) atesta que a personalidade atribuída à marca orienta a preferência e o consumo por parte dos consumidores, ideia apoiada por Blackston (1993), ao propor que a personalidade atribuída à marca é o ponto de partida para os consumidores articularem o seu relacionamento com ela. Assim, parece possível afirmar que há uma influência da personalidade atribuída à marca pelos consumidores na percepção do relacionamento que eles estabelecem com elas.

Dessa forma, a partir da contextualização por ora desenhada, propõe-se o seguinte problema de pesquisa: de que forma a personalidade atribuída às marcas de moda feminina de luxo influencia a percepção do relacionamento que as clientes têm com tais marcas?

Por conseguinte, o objetivo precípuo deste estudo é avaliar a relação entre a personalidade de marcas de moda feminina de luxo atribuídas pelas clientes e a percepção de seu relacionamento com tais marcas.

Para a consecução do objetivo geral, propõem-se os seguintes objetivos específicos:

I. Desenvolver uma escala de relacionamento com clientes de marcas de moda feminina de luxo;

II. Validar a escala de relacionamento com clientes de marcas de moda feminina de luxo;

III. Realizar a validação confirmatória do modelo exploratório de mensuração do relacionamento com marcas de moda feminina de luxo obtido no objetivo II;

IV. Identificar a personalidade atribuída às marcas de moda feminina de luxo mais citadas pelas clientes pesquisadas;

V. Identificar a percepção que as clientes de marcas de moda feminina de luxo possuem quanto ao seu relacionamento com elas;

VI. Verificar o ajuste de um modelo estrutural de medição englobando as duas variáveis pesquisadas, a saber, percepção de relacionamento e personalidade atribuída à marca, sendo a personalidade de marca preditora da percepção de relacionamento com a marca. 
Um trabalho científico precisa apresentar contribuições acadêmicas e gerenciais, haja vista que a administração é uma ciência essencialmente aplicada e nestas contribuições reside a justificativa e relevância do trabalho.

No que se refere às contribuições acadêmicas, este estudo busca preencher a lacuna na literatura de marketing de relacionamento no que tange ao mercado de luxo, ao validar um instrumento científico que permitirá avaliar a percepção das clientes de moda feminina de luxo quanto ao seu relacionamento com suas marcas preferidas, segmento ainda não investigado no contexto do CRM. Vale ressaltar que esta escala também viabilizará outros estudos relacionais nas áreas de marketing e comportamento do consumidor. Ademais, propõe-se a averiguação de uma relação inexplorada na literatura, a saber, a influência da personalidade atribuída às marcas de luxo na percepção do relacionamento com elas, contribuindo para os estudos que pretendem identificar antecedentes do marketing de relacionamento.

O nível de exigência dos consumidores e a crescente competitividade neste mercado exigem que as organizações utilizem seus recursos de forma diferenciada e funcional, onde o relacionamento com o cliente pode conferir às organizações um diferencial competitivo. Neste sentido, a personalidade de marca pode figurar como relevante pressuposto para o estabelecimento de um relacionamento de longo prazo, ultrapassando laços com os atributos físicos e desenvolvendo aspectos emocionais, facilitando a aceitação de novos produtos e enfatizando o valor e qualidade percebidos, o que se traduzirá em fidelidade à marca (SCHIFFMAN; KANUK, 2000).

Destarte, em relação às contribuições práticas, a escala que se propõe desenvolver e validar será uma proposta de diagnóstico que auxilie os gestores do mercado de moda feminina de luxo a tomar decisões, desvelando a personalidade atribuída às marcas, a qual pode ser enfatizada em estratégias e comunicações de marketing, bem como aspectos do relacionamento entre marcas e clientes, que podem ser trabalhados para aumentar a lealdade dos consumidores, o que, em última análise, traduz-se em melhores resultados organizacionais.

A presente dissertação, além da introdução, encontra-se assim estruturada: referencial teórico, abrangendo sínteses do estado da arte, revisões da produção nacional e institucionalização da pesquisa para cada variável pesquisada; modelo da pesquisa e descrição das variáveis; método, o qual enuncia a caracterização geral da pesquisa, do setor e da amostra, bem como os procedimentos de coleta, tratamento e análise dos dados; resultados e 
discussão; conclusão do estudo, com a síntese dos principais resultados, contribuições acadêmicas e gerenciais, bem como as limitações e recomendações para trabalhos futuros. Por fim, as referências bibliográficas e os apêndices encerram o documento. 


\section{REFERENCIAL TEÓRICO}

Esta seção apresenta a fundamentação teórica deste trabalho, resultado da revisão de literatura das variáveis relevantes à elaboração e consecução da pesquisa. Posto isto, o referencial teórico encontra-se dividido em duas partes, sendo a primeira dedicada à variável personalidade de marca e a segunda referente à variável CRM. Ambas as partes contemplam o estado da arte, a revisão da produção nacional e o mapeamento da institucionalização da pesquisa sobre cada variável no Brasil, computando seus índices de produção científica e tecnológica.

\subsection{PERSONALIDADE DE MARCA}

A seção que se apresenta é referente à variável personalidade de marca, contemplando o estado da arte sobre o tema, a revisão da produção nacional recente, entre os anos de 2010 e 2015, e a institucionalização da pesquisa na área.

\subsubsection{Personalidade de Marca: Estado da Arte}

O atual cenário econômico coloca às organizações a necessidade de criação de estratégias que as permitam vantagens em um ambiente extremamente competitivo, fazendo com que a busca por diferenciação seja constante, e que as marcas atuem como elemento diferenciador (MUNIZ; MARCHETTI, 2012). Neste contexto, uma das razões pelas quais o estudo das marcas ganha relevância é o fato de melhorarem a produtividade das atividades de marketing, ou seja, custos mais altos, ambiente competitivo e demanda flutuante em muitos mercados fazem com que as organizações procurem compreender o comportamento do consumidor como fonte para decisões estratégicas na área (KELLER, 2009).

Uma marca pode ser considerada um símbolo representativo de uma variedade de ideias e atributos que se comunicam com o consumidor através das associações construídas durante um período de tempo (GARDNER; LEVY, 1955). Para Kotler e Keller (2012), a marca consiste em um nome, termo, sinal, símbolo ou desenho - ou uma combinação desses elementos - que identifica o fabricante ou vendedor de um produto ou serviço e diferencia os seus serviços daqueles oferecidos pelos concorrentes. Há de se ressaltar que uma marca não é um produto, mas sim a essência do produto, seu significado e direção, o que define sua identidade no tempo e no espaço (KAPFERER, 2003). 
Uma marca pode ser analisada sob três perspectivas distintas: (1) na forma de ativos legais, cuja propriedade é conhecida e protege a organização da concorrência; (2) como ativos de construção de relacionamentos com os consumidores e (3) como ativos financeiros (SCHULTZ; SCHULTZ, 2003).

De Chernatony (2005), em revisão de literatura sobre o significado das marcas, identificou as principais definições para o termo dentro das disciplinas de comportamento do consumidor e administração de marketing, a saber: um logotipo ou elemento visual; um instrumento legal que declara a propriedade; uma empresa, composta por seus produtos e pelas pessoas; um nome ou abreviatura capaz de trazer recordações ao consumidor nas decisões de compra; um redutor do risco percebido pelo consumidor na avaliação de produtos e serviços; um posicionamento, em que a marca se associa a uma função ou serviço; uma personalidade ou somatória de atributos e valores psicológicos, muitas vezes mais valorizados pelos consumidores que aspectos funcionais; um aglomerado de valores distintos que a distingue das demais; uma visão, no sentido estratégico; um valor agregado; uma identidade, centrada nas metas e valores projetados pela instituição; uma imagem ou perspectiva centrada na percepção do consumidor e, ainda, um relacionamento.

Na década de 1950, Gardner e Levy (1955) discutiam a respeito do relacionamento construído entre marca e consumidores, alertando que tal relação era composta de aspectos racionais, mas também englobava aspectos que iam além destes. Mais tarde, Sirgy (1982) complementa que os consumidores avaliam uma marca, produto ou fornecedor não apenas pelas suas características físicas, mas por meio de um somatório de fatores, que inclui embalagens, propaganda, preço e associações feitas pelo consumidor, bem como os estereótipos do usuário típico do produto ou da marca.

Neste sentido, Kapferer (2003) afirma que o conceito de marca abrange todas as impressões positivas e negativas formadas pelo consumidor ao longo do tempo, considerando dimensões como produto, rede de distribuição, pessoal e comunicação. Para o autor, a marca desperta a boa vontade, ou goodwill, dos consumidores, definida como uma atitude ou predisposição favorável em relação à empresa ou produto, criada pelas experiências positivas dos clientes. Desta forma, a marca permite o desenvolvimento da lealdade dos clientes, dificultando a migração dos mesmos para a concorrência e potencializando os recursos promocionais da organização (AAKER; JOACHIMSTHALER, 2000).

É relevante também assinalar a importância da marca no processo de decisão de compra. A marca influencia todo o processo decisório de compra, incluindo o reconhecimento 
da necessidade, a busca por informações, a avaliação de alternativas e a redução do esforço empenhado na pesquisa por alternativas disponíveis (SOLOMON, 2011). O autor aponta ainda a diminuição do risco percebido pelo consumidor, indicando sua sensibilidade em relação aos riscos monetário, físico, funcional, social e psicológico de uma escolha errada. No contexto brasileiro, estudos mostraram que a marca tem grande relevância no processo de decisão de compra (CUNHA; LUCE; KLERING, 1997; URDAN; URDAN, 2001; GONÇALVES FILHO; SALES; GOSLING, 2013; SANTINI; LADEIRA; LUBECK; ROTTA, 2014).

Assim, Aaker (1998) defende que a marca passa a caracterizar uma fonte sustentável de vantagem competitiva, pois reflete aos consumidores as razões pelas quais devem comprar determinada marca. Destarte, a marca toma a forma de um importante ativo organizacional: o conhecimento criado na mente dos consumidores (KELLER, 2009). Por conseguinte, enfatiza-se a importância de criar formas que ajudem o consumidor a organizar todo o conhecimento sobre produtos e serviços, com o objetivo de auxiliar a tomada de decisão, ao passo que este processo gere valor à empresa (KOTLER; KELLER, 2012).

Surge, assim, o conceito de valor da marca, do inglês brand equity, cuja definição consiste no conjunto de efeitos ou resultados ligados a uma marca, que se adiciona ao valor oferecido por seu produto ou serviço (AAKER, 1998). Uma outra definição para valor de marca consiste no efeito diferencial que o conhecimento sobre uma marca tem sobre a resposta do consumidor aos esforços de marketing (KOTLER; KELLER, 2012).

Estes efeitos ou resultados do conhecimento da marca pelo consumidor podem ser traduzidos em atitudes em relação à marca, reconhecimento, imagem e conhecimento da marca, bem como resultados observados no nível da organização, a saber, preço, participação de mercado, receita e fluxo de caixa (AILAWADI; LEHMANN; NESLIN, 2003). Para Kapferer (2003), o valor de marca engloba ativos como notoriedade, nível de qualidade percebido e comparação com os concorrentes, nível de confiança, pertinência, empatia, estima, riqueza e atratividade do imaginário da marca, referentes aos atributos não-materiais relacionados ao consumo da mesma.

Na mesma linha, Keller (2012) conceitua valor da marca em relação aos efeitos atribuídos à mesma, o que reflete a percepção do consumidor e suas implicações, buscando revelar de que forma este consumidor organiza o conhecimento sobre a marca em sua memória. Por conseguinte, o valor da marca será positivo ou negativo em decorrência das reações do consumidor frente ao produto, preço, promoção e distribuição de uma marca. Para 
o autor, a atenção dada aos aspectos intangíveis da marca deve-se à tentativa de preencher a lacuna existente quanto aos aspectos negligenciados quanto ao conhecimento da marca pelos consumidores que apresentam implicações teóricas e gerenciais significativas.

Assim, existem duas motivações para o estudo do valor da marca. A primeira refere-se às motivações financeiras, onde estima-se o valor da marca em termos contábeis, a serem utilizados, por exemplo, em fusões, aquisições e decisões de investimentos; a segunda consiste em uma motivação estratégica, com o objetivo de melhorar a produtividade de mercado, o que demanda a compreensão de aspectos do comportamento do consumidor para decisões de mercado e de posicionamento (KELLER, 2012). Nesta perspectiva, o autor aponta que o valor da marca se identifica na medida em que o consumidor tem familiaridade com uma marca, apresentando associações fortes, favoráveis e únicas na memória.

$\mathrm{Na}$ mesma linha, Keller (2009) sugere que o ativo mais importante de uma organização passa a ser o conhecimento criado na mente dos consumidores, propondo, ainda, que este conhecimento seja analisado sob duas dimensões distintas: a lembrança da marca e a imagem da marca. A lembrança da marca relaciona-se à força com que o consumidor recupera as informações sobre a marca em sua memória, sendo relevante no processo de tomada de decisão por aumentar a probabilidade de a marca ser lembrada no conjunto de alternativas consideradas (KELLER, 2012).

Biel (1993) define imagem de marca como um agrupamento de atributos e associações que os consumidores conectam a uma marca. Além disso, a imagem de marca é formada por três componentes: a imagem do provedor do produto ou serviço, referente à imagem da organização, a imagem do usuário e a imagem do produto ou serviço. Segundo o autor, a imagem da marca orienta o valor da marca e, desta forma, os resultados financeiros da organização, o que reforça a relevância de sua análise.

Para Keller (2012), por sua vez, a imagem da marca é definida como as percepções em relação à marca, enquanto resultado das associações existentes na memória do consumidor. Segundo o autor, associações fortes, únicas e favoráveis distinguem o conhecimento da marca na determinação das respostas do consumidor nos processos de decisão. Tais associações podem ainda ser classificadas em três categorias: atributos, benefícios e atitudes.

Os atributos são características que descrevem o produto ou serviço de acordo com a percepção dos consumidores. Tais atributos podem estar relacionados com os produtos ou serviço em si e seu desempenho, como podem ser externos ao produto, compreendendo 
aspectos como preço, embalagem, usuário típico e imaginário do uso do produto, que se refere aos tipos de situação em que o produto ou serviço é utilizado (KELLER, 2012).

A segunda categoria, segundo o autor, refere-se aos benefícios, que são os valores pessoais que os consumidores associam aos atributos do produto ou serviço em relação ao que estes podem fazer pelo consumidor. Dividem-se em benefícios funcionais, experimentais e simbólicos. Os primeiros consistem nas vantagens intrínsecas do produto advindas do seu consumo, sendo atributos relacionados ao produto. Os benefícios experimentais, por sua vez, relacionam-se à experiência no uso do produto ou serviço, como prazer, variedade e estimulação cognitiva, geralmente associados aos atributos do produto ou serviço. Por fim, de acordo com Keller (2012), tem-se os benefícios simbólicos, correspondendo aos atributos não relacionados ao produto e que apresentam ligação com necessidades de aprovação social ou expressão pessoal, como necessidade de prestigio social ou exclusividade. A terceira categoria discorre sobre as atitudes em relação à marca, que se referem às avaliações feitas pelos consumidores sobre as marcas, e sua relevância reside no fato de que formam uma base para a escolha do consumidor (KELLER, 2012).

Assim, tem-se que a imagem de marca é um aspecto oriundo das associações realizadas na mente do consumidor. Por outro lado, a identidade de marca é uma projeção realizada pela própria empresa. A identidade de uma marca deve ser capaz de proporcionar sentido, finalidade e significado à marca, através da visão estratégica e gerencial desenvolvida pela organização, estimulando as associações que compõem o coração e o espírito da marca (AAKER; JOACHIMSTHALER, 2000).

A identidade da marca consiste em uma emissão da concepção que a marca tem de si mesma (KAPFERER, 2003). O autor defende, ainda, que a identidade antecede a imagem, pois é a partir do que a organização projeta sobre uma marca que o consumidor irá fazer associações e, desta forma, construir uma imagem da marca. Neste sentido, Aaker e Joachimsthaler (2000) sugerem que a identidade de marca demonstra as estratégias e valores da empresa, auxiliando o estabelecimento do relacionamento entre marca e cliente, por meio da oferta de uma proposta de valor que inclua os benefícios valorizados pelos consumidores.

Para Aaker e Joachimsthaler (2000), a identidade da marca é composta por doze dimensões, organizadas em quatro perspectivas: (1) a marca como produto, incluindo as dimensões escopo, atributos, qualidade, uso, usuários e país de origem; (2) a marca como organização, com as dimensões inovação, preocupações e características locais versus globais; (3) a marca como pessoa, onde se verificam as dimensões de personalidade e do 
relacionamento com o cliente; e (4) a marca como um símbolo, englobando imagens visuais, metáforas, tradição e herança da marca.

De acordo com a perspectiva da marca como pessoa, Aaker e Joachimsthaler (2000) situam a personalidade da marca como um elemento central, sugerindo que esta perspectiva torna a identidade da marca mais rica e interessante. Neste contexto, Kapferer (2003) defende que a personalidade de uma marca tem início quando ela começa a se comunicar, momento em que adquire um "caráter", que, por sua vez, é definido como as características mais fortes da personalidade (NUTTIN, 1969; FILLOUX, 1983). Assim, Kapferer (2003) argumenta que os produtos deixam transparecer o tipo de pessoa que a marca seria, caso se queira comparar a marca a uma pessoa.

Devido ao forte apelo que as marcas têm para os consumidores, os indivíduos cada vez mais tendem a construir um relacionamento com as marcas, pautado na compatibilidade entre consumidor e marca, em que se atribui às marcas características humanas (FOURNIER, 1998). Nesta linha, a pesquisa em comportamento do consumidor tem explorado o modo pelo qual a personalidade de marca permite ao consumidor expressar a imagem que tem de si mesmo (FERRANDI; MERUNKA; VALETTE-FLORENCE; DE BARNIER, 2002). Dentro desta perspectiva, faz-se necessário conceituar personalidade humana e discutir sua contribuição aos estudos sobre marcas.

Para Rebollo e Harris (2006), a personalidade humana refere-se a padrões de comportamento e atitudes típicas de um indivíduo, permitindo sua diferenciação entre os demais através dos traços de personalidade que, segundo os autores, tendem a ser estáveis e relativamente constantes. Na mesma linha, Trentini, Hutz, Bandeira, Teixeira, Gonçalves e Thomazoni (2009) descrevem a personalidade como características do indivíduo, sendo única e capaz de distingui-lo de outros indivíduos por meio de padrões conscientes de sentimentos, pensamentos e comportamentos. Os traços de personalidade, por sua vez, consistem em características psicológicas que representam tendências na forma de pensar, sentir e agir (SISTO; OLIVEIRA, 2007). Os autores ressaltam ainda que, apesar de os traços de personalidade serem relativamente estáveis, podem sofrer efeito de mudanças, uma vez que se constituem como produto das interações das pessoas com o meio.

Alguns autores tradicionais da psicologia defendem que a verificação da estrutura da personalidade humana se dá por meio do grau de relação entre as várias formas de comportamento de um indivíduo ou entre os traços de personalidade (NUTTIN, 1969; ALLPORT, 1973). Neste sentido, Allport (1973) propõe a utilização da análise fatorial, uma 
vez que este método pode conduzir a um conjunto de características fundamentais da natureza humana, reduzindo tais características às suas dimensões essenciais ou fatores (NUTTIN, 1969). Para cumprir este objetivo, Allport (1973) sugere a identificação de traços comuns que sejam identificáveis dentro de determinado contexto, e, se possível, de maneira universal e generalizada.

A partir destes pressupostos, de acordo com Prinzie, Stams, Dekovic, Reijntjes e Belsky (2009), a pesquisa em personalidade ganhou uma nova direção quando do estabelecimento de sua estrutura, a saber, um modelo fatorial de personalidade baseado em cinco fatores. Este modelo adota a terminilogia Big Five e é composto por cinco dimensões que refletem os traços estáveis e recorrentes de um indivíduo, em oposição a estados temporários que não são considerados na descrição de sua personalidade (GOLDBERG, 1990). O modelo Big Five surgiu na década de 1930 com os estudos de Gordon Alpport e avançou na década seguinte a partir dos estudos de Raymong Cattell, autores que afirmavam que nomes e adjetivos capazes de descrever a personalidade humana fazem parte do desenvolvimento e da manutenção das relações sociais (CAPRARA; BARBARANELLI; GUIDO, 2001). A pesquisa de Digman (2002) revela ainda que apesar de o modelo ter início nos anos 1930, solidificou-se apenas na década de 1980 com estudos empíricos como os de Goldberg (1981), Costa e McCrae (1988) e McCrae e Costa (1989), entre outros.

O modelo Big Five apresenta os cinco fatores da personalidade humana como sendo (1) Extroversion, que descreve a preferência por interação social; (2) Agreeableness, descrevendo aspectos de preocupação com outros indivíduos; (3) Conscientiousness, revelando a preferência por uma atividade orientada; (4) Neuroticism revelando a habilidade de se lidar com emoções negativas; e (5) Openess to Experience, que descreve a tolerância a novas ideias, demonstrando abertura a novas experiências (COSTA; McCRAE, 1992; GOLDBERG, 1992; 1993). O estudo de Caprara, Barbaranelli e Guido (2001) sugere ainda que o fator Neuroticism seja substituído por Emotional Stability, que revelaria a "habilidade para lidar de forma eficiente com as emoções negativas" (CAPRARA; BARBARANELLI; GUIDO, 2001, p. 380).

No Brasil, estes cinco fatores foram traduzidos como "Extroversão, Socialização, Realização, Neuroticismo e Abertura à Experiência" (SILVA; NAKANO, 2011, p. 3). As autoras relatam, ainda, a existência de divergências em relação aos nomes dados aos fatores nos estudos brasileiros, todavia, salientam que as definições têm caráter consensual e apontam características semelhantes. 
Dentro da definição proposta por Nunes e Hutz (2007), o fator extroversão refere-se à quantidade e à intensidade das interações pessoais, nível de ativide, necessidade de estimulação e capacidade de alegrar-se; o fator socialização, por sua vez, descreve a qualidade das relações interpessoais do indivíduo, revelando a compatibilidade de um indivíduo dentro do convívio social; o fator realização representa o grau de organização, persistência, controle e motivação de um indivíduo; o fator neuroticismo revela uma propensão a sofrimentos psicológicos, podendo englobar níveis de ansiedade, depressão, hostilidade, vulnerabilidade e impulsividade; e o fator abertura à experiência, por fim, relaciona-se a comportamentos exploratórios, onde o indivíduo valoriza novas experiências, mostrando-se imaginativo, criativo e curioso. Os autores sugerem ainda, que o contrário de um indivíduo aberto a novas experiência revelaria um indivíduo convencional, com crenças e atitudes mais conservadoras.

Há de se ressaltar que a importância e a elevada utilização do modelo Big Five dentro dos estudos de personalidade humana sustentam-se na sua generalização e estabilidade, que são garantidas pelo fato de o modelo ter sido aplicado a diversas amostras, em diferentes culturas e através de fontes de informação distintas, apresentando adequação em todos os usos (CAPRARA; BARBARANELLI; GUIDO, 1998; 2001; SILVA; NAKAMO, 2011).

A partir da década de 1950, a área de marketing começou a reconhecer o termo personalidade na descrição de empresas, produtos e marcas, assumindo que o termo ajudaria a compor uma imagem pública, relevante para o status da marca, indo além dos atributos físicos dos produtos (GARDNER; LEVY, 1955). Na mesma época, a imagem e personalidade de lojas foram estudadas como fator de diferenciação em estudos de segmentação, onde se busca atingir um grupo específico de consumidores (MARTINEAU, 1958). Foi na década de 1980, porém, que esta linha de pesquisa ganhou consistência, quando alguns estudos passaram a sugerir a utilização dos conceitos de personalidade humana e seus instrumentos de mensuração nos estudos sobre personalidade de marca (PLUMMER, 1985; BERRY, 1988; DURGEE, 1988).

Conforme Plummer (1985), a personalidade de marca pode ser entendida a partir de duas perspectivas: a primeira refere-se ao que as empresas desejam que os consumidores sintam em relação às marcas, o que se relaciona aos objetivos de comunicação das empresas, e é utilizado como estratégia criativa, e o segundo representa o que os consumidores de fato pensam e sentem, que constitui a percepção do consumidor em relação à marca. Neste sentido, o autor defende que o objetivo da personalidade de marca é descrever a realidade perceptual a partir da percepção do consumidor, refletindo seus sentimentos sobre a marca, 
em vez de expressar apenas o que as empresas gostariam que os consumidores sentissem em relação à marca. É de acordo com esta segunda perspectiva, em que a personalidade de marca é definida pela percepção do consumidor, que o presente estudo se pautará.

Nesta linha, Batra, Lehmann e Singh (1993) definem personalidade de marca como o modo através do qual os consumidores percebem a marca em dimensões que tipicamente descrevem a personalidade de um indivíduo. Uma vez que as marcas são alvos de preferências, expectativas e atribuições, Caprara, Barbaranelli e Guido (1998) defendem ser plausível utilizar a mesma heurística que conduz à formação de impressão sobre uma pessoa à formação de impressão sobre uma marca. Segundo os autores, a personalidade serve como uma metáfora capaz de descrever as características estáveis na identificação de marcas e produtos. Desta forma, “a personalidade dos indivíduos é percebida, então, por meio do seu comportamento e, da mesma forma, os consumidores podem atribuir uma personalidade a uma marca de acordo com a comunicação e 'comportamento' percebidos” (AZOULAY; KAPFERER, 2003, p. 149).

Para Aaker (1997, p. 347), a personalidade de marca consiste no "conjunto de características humanas associadas a uma marca”, onde o uso simbólico de marcas é explicado pelo fato de os consumidores atribuírem às marcas traços da personalidade humana que as identificam e diferenciam.

A partir das conceitualizações do termo, Azoulay (2005) propôs que a pesquisa em personalidade de marca fosse categorizada em três grandes campos. Segundo o autor, o primeiro dedica-se ao desenvolvimento de escalas de personalidade de marca, enquanto o segundo refere-se à compreensão dos efeitos da conformidade entre a personalidade de marca e a personalidade do consumidor. Por fim, tem-se o campo de estudo dedicado ao impacto da personalidade de marca no comportamento do consumidor (AZOULAY, 2005), corroborando com a literatura que sinaliza sinaliza possibilidades de haver um impacto da personalidade da marca no comportamento dos consumidores.

No que tange aos estudos relacionais entre o construto personalidade de marca e diversas outras variáveis, a literatura em personalidade de marca revela que duas tradições de pesquisa podem ser identificadas. A primeira delas refere-se a uma linha mais psicológica, visando à compreensão da influência da congruência entre as personalidades do consumidor e da marca na preferência por produtos (ZENTES; MORSCHETT; SCHRAMM-KLEIN, 2008; PARKER, 2009; LEE; BACK; KIM, 2009; LEE, 2009; LEE; BACK, 2010; PARK; JOHN, 2010; BRANAGHAN; HILDEBRAND, 2011; HUANG; MITCHELL; 
ROSENAUM-ELLIOTT, 2012; ROMANIUK; EHRENBERG, 2012; SCHMITT, 2012; DE

LIMA; BAPTISTA, 2013). A segunda linha de pesquisa está ligada a uma abordagem mercadológica, uma vez que trata do impacto da personalidade da marca no comportamento de compra dos consumidores. Cabe destacar que as duas tradições observadas nos estudos relacionais corroboram as categorias propostas por Azoulay (2005).

Destarte, quanto aos estudos empíricos que visam compreender o impacto da personalidade de marca no comportamento dos consumidores, identificou-se a relação entre a personalidade de marca e variáveis como percepção de qualidade da marca, confiança, afeto e comprometimento à marca, atitude e intenção de comportamento futuro de compra. Visando explorar o tema nas pesquisas acadêmicas, foi realizado um levantamento da literatura científica a fim de identificar os trabalhos realizados sobre o tema, compreendendo as publicações dos mais recentes, o que contempla o período entre 2010 e julho de 2015. Os resultados desta busca são descritos abaixo.

Quanto aos resultados desta busca, observou-se que a produção empírica recente na área

evidenciou a personalidade de marca como importante componente das estratégias de diferenciação competitiva (FLORENCE; GUIZANI; MERUNKA, 2011; MALAR; NYFFENEGGER; KROHMER; HOYER, 2012; MATHUR; JAIN; MAHESWARAN, 2012; NARESH, 2012), tendo impacto, ainda, na qualidade do relacionamento entre marca e consumidor, trazendo à tona a influência do consumo simbólico no delineamento das estratégias empresariais (NOBRE; BECKER; BRITO, 2010). Ademais, pesquisas dedicaramse a analisar os efeitos da personalidade de marca nas estratégias de posicionamento de marca (KIM; SUNG, 2013), no desenvolvimento da persuasão dentro na publicidade (PARK; JOHN, 2012) e, neste contexto, a utilização de celebridades para o endosso de marcas, explorando a influência de traços de personalidade de marca (ARSENA; SILVERA; PANDELAERE, 2014). Ademais, a personalidade de marca passa a ser estudada, ainda, dentro do marketing sensorial, sob a ótica das estratégias de criação de experiências para o consumidor (MOLLER; HERM, 2013).

Sob diferente perspectiva, os estudos na temática voltam-se à formação da impressão do consumidor, evidenciando o fator cultural como importante elemento da construção da 
personalidade atribuida a uma marca (FETSCHERIN; TONCAR, 2010; MOYA; JAIN, 2013). Os construtos confiança e apego à marca também são identificados na literatura associados aos conceitos lealdade à marca (LEE; BACK, 2010), comprometimento à marca (LOUIS; LOMBART, 2010) e, recentemente, estudados à luz da gestão de pessoas, mais espeficicamente sobre a atração e retenção de talentos (RAMPL; KENNING, 2014).

Observou-se, também, o interesse dos pesquisadores quanto à influência da personalidade de marca em comportamentos futuros (AKIN, 2011), à relação entre personalidade de marca, preferência pela marca e lealdade (KIM; MAGNINI; SINGAL, 2011) e, recentemente, à personalidade de marca corporativa (RAFFELT; SCHMITT; MEYER, 2013).

No que tange a revisões de literatura dentro do tema, com o objetivo de identificar as perspectivas abarcadas pelos estudos em personalidade de marca, identificou-se o estudo de Avis, Aitken e Ferguson (2012), que conduziu uma revisão de literatura examinando 130 artigos de diferentes bases de dados. Os resultados indicaram três grandes perspectivas: (1) perspectiva humanlike ou humanóide de marca, onde marcas são percebidas pelos consumidores como uma entidade humana; (2) perspectiva metafórica do pesquisador, em que os conceitos de personalidade de marca e relacionamentos com marcas são metáforas usadas pelos pesquisadores para explicar as percepções de marcas que os consumidores apresentam; e (3) perspectiva metafórica do consumidor, na qual consumidores utilizam uma linguagem figurada para descrever marcas, por sua vez capturadas através do relacionamento com as marcas e também dos conceitos de personalidade de marca.

Quanto à mensuração da personalidade da marca, devido à necessidade latente do entendimento da percepção dos consumidores em relação às marcas por parte das organizações, Shank e Langmeyer (1994) atentam para a relevância de ferramentas e instrumentos válidos e confiáveis capazes de mensurar a personalidade de marcas e produtos, sejam eles de natureza qualitativa ou quantitativa. Salienta-se, ainda, que até meados da década de 1990 não havia uma escala que atendesse aos critérios de confiabilidade, validade e generalização, visto que até então as escalas de mensuração tendiam a ser ad hoc, como checklists, photo-sorts e analogias simbólicas (AAKER, 1997).

Dentro de uma abordagem qualitativa, as escalas ideográficas são construídas por meio de estudos qualitativos para elucidar as características de determinada marca ou empresa, sendo relevante apenas para a marca pesquisada (HELGESON; SUPPHELLEN, 2004). Hooley, Saunders e Piercy (2005) acrescentam que, enquanto a abordagem qualitativa 
foca em um objeto de forma isolada, as abordagens quantitativas tentam englobar o uso de escalas de atributos como uma maneira simples de coletar dados.

Conforme citado por Aaker (1997), as escalas advindas da psicologia tiveram grande contribuição para os estudos em personalidade de marca. Isso se deve ao fato de que as marcas, assim como as pessoas, são descritas por adjetivos, fazendo com que "a abordagem utilizada nas escalas de personalidade humana constitua um bom método para identificar as principais características das personalidades das marcas na percepção dos consumidores" (CAPRARA; BARBARANELLI; GUIDO, 2001, p. 381). Há de se ressaltar que alguns estudos foram realizados com o objetivo de testar empiricamente as escalas de mensuração da personalidade humana (GOLDBERG, 1990; SAUCIER, 1994) na mensuração na personalidade de marcas (CAPRARA; BARBARANELLI; GUIDO, 1998; 2001; FERRANDI et al., 2002).

Caprara, Barbaranelli e Guido (1998) conduziram três estudos com o objetivo de verificar a possibilidade de o modelo Big Five de personalidade humana (GOLDBERG, 1990) poder ser estendido às marcas, além de testar se a estrutura fatorial do modelo manter-se-ia quando aplicadas ao contexto apresentado. Os resultados indicam que a metáfora proposta pelos autores é válida, podendo a personalidade humana ser utilizada para descrever marcas. Anos mais tarde, Caprara, Barbaranelli e Guido (2001), propuseram um novo estudo, cujo objetivo consistia em investigar em que extensão o modelo Big Five se aplica à descrição de características de marcas. De acordo com os autores, os descritores de personalidade humana apresentam diferentes significados quando atribuídos a diferentes marcas, revelando que o repertório da personalidade humana pode auxiliar na construção da personalidade de marca, mas de maneira limitada.

De forma semelhante, Ferrandi et al. (2002) buscaram aplicar a escala de personalidade humana Mini-Makers (SAUCIER, 1994) diretamente na descrição da personalidade de marca na França. Os autores solicitaram aos sujeitos que avaliassem a sua própria personalidade por meio da escala de Saucier (1994), desenvolvida a partir do modelo Big Five, com menor número de itens, mantendo a robustez e credibilidade do modelo. Em seguida, os autores solicitaram aos participantes que avaliassem também a personalidade de marca de produtos pertencentes a diferentes categorias. Os resultados indicaram a validade da replicação da escala no que tange à avaliação da personalidade dos sujeitos, verificando que as escalas apresentaram estruturas fatoriais similares, permitindo posicionar as marcas pesquisadas em diferentes dimensões da personalidade humana. 
Apesar das contribuições dos estudos supracitados, Aaker (1997) aponta como ponto de reflexão o fato de que a forma utilizada para medir a personalidade de marca consistia na aplicação de escalas de personalidade humana da psicologia, sem que houvesse qualquer tipo de validação para o contexto das marcas, o que poderia revelar problemas. Verificou-se, então, que a aplicação destas escalas se mostrou limitada quanto à descrição da personalidade de marcas (CAPRARA; BARBARANELLI; GUIDO, 1998; 2001; FERRANDI et al., 2002).

Esta limitação pode ser atribuída aos antecedentes de personalidade humana e de personalidade de marca. Para Aaker (1997), ainda que os construtos supracitados apresentem similaridades, eles diferem pela maneira por meio da qual foram formados: os traços de personalidade humana são formados a partir do comportamento do indivíduo, suas características físicas, atitudes e crenças, enquanto os traços de personalidade de marca originam-se e são influenciados por qualquer contato direto ou indireto que um consumidor tenha com uma marca. Desta forma, fazia-se necessário o desenvolvimento de uma escala que suprisse tal lacuna.

Posto isto, Aaker (1997) propôs em seu estudo o desenvolvimento da Escala de Dimensões da Personalidade de Marca, isolando estas dimensões distintas ao invés de tratar a personalidade de marca como um construto unidimensional. Assim, os diferentes tipos de personalidade de marca podem ser identificados, tornando a influência de cada dimensão na preferência do consumidor mais compreensível. O estudo, realizado nos Estados Unidos, selecionou marcas salientes e bem conhecidas, para que uma amostra de abrangência nacional pudesse ser utilizada, como por exemplo, a marca Levi's (AAKER, 1997). Os resultados das análises fatoriais exploratória e confirmatória identificaram, para o contexto americano, que os indivíduos percebem as marcas em termos de cinco dimensões de personalidade, a saber: (1) Sincerity ou sinceridade, (2) Excitement ou excitação/agitação, (3) Competence ou competência, (4) Sophistication ou sofisticação e (5) Ruggedness ou robustez (Aaker, 1997). O Quadro 1 representa as dimensões de personalidade de marca identificadas no contexto americano, propostas por Aaker (1997). 
Quadro 1 - Escala de Dimensões de Personalidade de Marca

\begin{tabular}{|c|c|c|c|c|}
\hline \multicolumn{5}{|c|}{ PERSONALIDADE DE MARCA } \\
\hline SINCERIDADE & AGITAÇÃO & COMPETÊNCIA & SOFISTICAÇÃO & ROBUSTEZ \\
\hline Prática & Ousada & Confiável & Elitista & $\begin{array}{l}\text { Voltada para o ar } \\
\text { livre }\end{array}$ \\
\hline $\begin{array}{l}\text { Orientada para a } \\
\text { família }\end{array}$ & Última moda & Confiável & Elitista & $\begin{array}{l}\text { Voltada para o ar } \\
\text { livre }\end{array}$ \\
\hline $\begin{array}{l}\text { Coerente com } \\
\text { cidades pequenas }\end{array}$ & $\begin{array}{l}\text { Ousada } \\
\text { (provocativa) }\end{array}$ & Empenhada & Glamorosa & Masculina \\
\hline Prática (realista) & Excitante & Segura & Deslumbrante & do Oeste (ocidental) \\
\hline Honesta & Espitiruosa & Inteligente & Chamorsa & Obstinada \\
\hline Sincera & Legal & Inteligente & Feminina & Obstinada (Valente) \\
\hline Honesta & Espirituosa & Técnica & Feminina & Robusta \\
\hline Realista & Jovem & Corporativa & Delicada & \\
\hline Íntegra & Imaginativa & Bem-sucedida & & \\
\hline Original (genuína) & Única & Bem-sucedida & & \\
\hline Íntegra & Imaginativa & Líder & & \\
\hline & & Convicta & & \\
\hline Alegre & Atualizada & & & \\
\hline Alegre & Atualizada & & & \\
\hline Sentimental & Independente & & & \\
\hline Amigável & Contemporânea & & & \\
\hline
\end{tabular}

Fonte: Aaker (1997) (traduzido pela autora)

De forma a auxiliar à compreensão das dimensões de personalidade de marca, Maehle, Otnes e Supphellen (2011) propuseram estudo sobre a forma como os consumidores geram suas percepções em relação às diferentes dimensões de personalidade de marca identificadas na escala de Aaker (1997), identificando que as dimensões especificas de personalidade de marca estão associadas a determinadas categorias de produtos. As marcas consideradas sinceras são aquelas que fazem parte da rotina dos indivíduos; os consumidores utilizam tais marcas com frequência, confiando nas mesmas e desenvolvendo lealdade a elas. As marcas percebidas como competentes referem-se a marcas com aplicações técnicas; geralmente são marcas de grandes empresas, com produtos que são líderes de mercado ou fazem parte de empresas com tradição no mercado, extremamente competentes. As marcas tidas como excitantes estão relacionadas a produtos inovadores, sendo associadas às aspirações dos consumidores. As marcas vistas como sofisticadas tendem a ser marcas mais exclusivas e com 
acesso mais restrito, percebidas como especiais e são geralmente marcas mais caras. Por fim, as marcas avaliadas na dimensão robustez incluem produtos do universo masculino carros, onde as marcas assim avaliadas fazem parte do estereótipo masculino.

Azoulay e Kapferer (2003) e Avis (2012) concordam que a tradição de pesquisa em personalidade de marca, especialmente no que se refere às formas de mensuração do construto, tomou um novo rumo a partir do estudo seminal de Aaker (1997), que operacionalizou o conceito, determinando um número de dimensões constituintes da personalidade de marca (MUNIZ; MARCHETTI, 2012).

Em uma análise comparativa entre a escala de personalidade humana, representada pelo modelo Big Five (GOLDBERG, 1990), e a Escala de Dimensões de Personalidade de Marca (AAKER, 1997), observa-se que, entre as dimensões de personalidade de marca identificadas, três delas (sinceridade, agitação e competência) assemelham-se às dimensões de personalidade descritas pelo modelo Big Five (GOLDBERG, 1990). Embora a conexão entre sofisticação e robustez não seja tão clara, estas dimensões captam aspectos relacionados a bem-estar e status, ou ainda ao individualismo americano (AAKER; BENET-MARTINEZ; GAROLERA, 2001).

Neste sentido, Aaker (1997) argumenta que, apesar de as dimensões de personalidade humana (GOLDBERG, 1990) formarem uma medida generalizável quando aplicadas a outras culturas, a escala de dimensões de personalidade de marca não se encaixa no mesmo pressuposto. Enquanto o modelo Big Five de personalidade humana é universal, a personalidade de marca consiste em um construto específico de cada cultura (BOSNJAK; BOCHMANN; HUFSCHMIDT, 2007).

Desta forma, tem-se a necessidade da validação da medida proposta por Aaker (1997) para outras culturas, abrangendo o entendimento do uso simbólico das marcas nestes contextos. Assim, foram identificados alguns trabalhos que corroboram a hipótese de que o construto personalidade de marca apresenta diferentes dimensões em culturas distintas (AAKER; BENET-MARTINEZ; GAROLERA, 2001; CHAN; SAUNDERS; TAYLOR; SOUCHON, 2003; SUPPHELLEN; GRONHAUG, 2003; HELGESON; SUPPHELLEN, 2004; BOSNJAK; BOCHMANN; HUFSCHMIDT, 2007; MILAS; MLACIC, 2007; MUNIZ; MARCHETTI, 2012).

Aaker, Benet-Martinez e Garolera (2001) conduziram quatro estudos, dois no Japão e dois na Espanha, com o objetivo de examinar de que forma os atributos simbólicos e expressivos de marcas comerciais são estruturados, comparando os resultados da aplicação da 
escala de dimensões de personalidade de marca no contexto americano (AAKER, 1997) aos contextos japonês e espanhol.

Os estudos realizados no contexto japonês resultaram em cinco dimensões: Excitement, excitação ou agitação; Competence ou competência, Peacefulness ou tranquilidade; Sincerity ou sinceridade; e Sophistication ou sofisticação. Observa-se a ausência da dimensão Ruggedness, identificada no estudo original (AAKER, 1997) e o surgimento da dimensão Peacefulness, por sua vez, ausente no contexto americano. Os autores atribuem a esta distinção as diferenças culturais entre os contextos, o que tende a gerar diferenças perceptuais e de atitudes em relação às marcas.

No que se refere aos estudos conduzidos no contexto espanhol, foram também identificadas cinco dimensões de personalidade de marca, quais sejam, Excitement, excitação ou agitação; Sincerity ou sinceridade; Sophistication ou sofisticação; Peacefulness ou tranquilidade; e Passion ou paixão. Observa-se novamente a ausência da dimensão Ruggedness, mas também da dimensão Competence. Por outro lado, assim como no contexto japonês, tem-se a dimensão Peacefulness, além do surgimento da dimensão Passion, que os autores justificam ser uma característica de culturas latinas, representando intensidade no relacionamento e vivência de emoções, fatores associados a valores religiosos, conceito de honra e personalidades mais aguerridas e de temperamento específico.

Supphellen e Gronhaug (2003) realizaram um estudo na Rússia, com a aplicação da escala proposta por Aaker (1997), com o objetivo de identificar a natureza das percepções da personalidade de marca, tendo como objetos e estímulos para a pesquisa duas marcas americanas em categorias distintas de produtos, a saber, Ford e Levi's. Na Rússia, assim como nos outros contextos citados, surgiram também diferentes dimensões das propostas por Aaker (1997), quais sejam, Successful e Contemporary ou bem-sucedida e contemporânea; Sincerity ou sinceridade; Excitement, excitação ou agitação; Sophistication ou sofisticação; e Ruggedness ou robustez.

Adicionalmente, com base em Aaker (1997) e Aaker, Benet-Martinez e Garolera (2001), a pesquisa de Chan et al. (2003) propuseram-se a identificar as dimensões de personalidade de marca entre consumidores chineses. Os autores encontraram um conjunto de 68 traços de personalidade, resultantes de uma solução de quatro fatores, revelando quatro dimensões de personalidade de marca, a saber, Competence ou competência; Excitement, excitação ou agitação; Sincerity ou sinceridade; e Fascination ou fascinação, que os autores 
compararam à Sophistication ou sofisticação, da escala de Aaker (1997), uma vez que as duas dimensões compartilham os traços glamurous e feminine (glamour e feminilidade).

Outros estudos, baseados na escala de Aaker (1997) foram realizados visando examinar o impacto dos significados culturais na personalidade de marca. Sung e Tinkham (2005) analisaram as dimensões compartilhadas entre as culturas americana e coreana em relação a marcas globais, cenário em que foram identificadas as likeableness ou estima, trendiness ou modismo, competence ou competência, sophistication ou sofisticação, traditionalism ou tradicionalismo e ruggedness ou robustez. Por outro lado, foram identificadas dimensões específicas da cultura coreana, como passive likeableness ou estima passiva e ascendancy ou ascendência. Por sua vez, o estudo de Bosnjak, Bochmann e Hufschmidt (2007) consistiu no desenvolvimento e validação de uma escala de personalidade de marca na Alemanha, contexto em que foram identificadas quatro dimensões de personalidade de marca, quais sejam, drive ou direcionamento, conscientiousness ou conscientização, emotion ou emoção e superficiality ou superficialidade.

Aaker (1997) aponta a necessidade de validação da escala de personalidade de marca para o contexto cultural onde ela é aplicada. Contudo, após ampla validação e aceitação da escala original, a literatura passa a sinalizar estudos onde a escala de personalidade de marca é validada para setores específicos (KAPLAN; YURT; GUNERI; KURTULUS, 2010; KIM; BAEK; MARTIN, 2010; HERBST; MERZ，2011; FLORENCE; BARNIER, 2013; LEONARD; KATSANIS, 2013; MENDEZ; MURPHY; PAPADOPOULOS, 2013; SUNG et al., 2015).

Kaplan et al. (2010) aplicaram o conceito de personalidade de marca a cidades, onde a personalidade de marca de uma cidade consiste no conjunto de características humanas associadas à marca de uma cidade, sendo o resultado da combinação de atributos utilitários, simbólicos e experienciais, originários da herança cultural, aspectos do ambiente e de sua população. Os resultados do estudo realizado na Turquia demonstram a possibilidade de diferenciar destinos de acordo com a sua personalidade, encontrando-se as seguintes dimensões para as cidades turcas: excitement ou excitação, malignancy ou malignidade, peacefulness ou tranquilidade, competence ou competência, conservatism ou conservadorismo e ruggedness ou robustez.

Com abordagem semelhante, Mendez, Murphy e Papadopoulos (2013) utilizaram a metáfora da personalidade de marca para examinar de que forma os chineses percebiam a personalidade da marca Estados Unidos, desenvolvento, para tanto, uma escala de 
personalidade de marca nacional. Os resultados indicam que a personalidade da marca Estados Unidos é um construto multidimensional composto de três dimensões principais: amicableness ou capacidade de ser amigável, resourcefulness ou capacidade de gerar recursos e self-centeredness ou egocentrismo. A percepção dos chineses em relação aos Estados Unidos como marca cerca o tipo bipolar de personalidade, visto que a dimensão egocentrismo é quase oposta às características das outras duas dimensões identificadas. Ainda, a escala de personalidade de marca desenvolvida mostra-se um importante preditor das intenções comportamentais da população chinesa em relação aos Estados Unidos.

O estudo de Aaker (1997) deu origem, ainda, ao desenvolvimento da escala de personalidade de marca no contexto de mídias em comunicação (KIM; BAEK; MARTIN, 2010), à escala de apelo da personalidade de marca (FRELING; CROSNO; HENARD, 2011), à escala corporativa de personalidade de marca (HERBST; MERZ, 2011), à escala de personalidade de marca de medicamentos (LEONARD; KATSANIS, 2013) e à escala de personalidade de marca para o setor de mídia impressa (FLORENCE; BARNIER, 2013). Os resultados deste último estudo, ainda, revelara que a abordagem micro ou seja, a validação ao contexto-específico, permite a identificação de traços de personalidade mais específicos a serem obtidos em determinados setores, enquanto a abordagem macro é mais genérica e, por isso, sofre com a ausência de itens específicos às áreas de estudo.

Recentemente, Sung et al. (2015) desenvolveram e validaram, nos Estados Unidos, a Escala de Personalidade de Marca aplicada ao setor de marcas de luxo. Como resultado, seis dimensões foram identificadas: excitação, sinceridade, sofisticação, profissionalismo, atratividade e materialismo. Destas, três dimensões, sinceridade, excitação e sofisticação, compartilham similaridades com as dimensões encontradas por Aaker (1997). As outras três dimensões, profissionalismo, atratividade e materialismo, refletem significados únicos e específicos às marcas de luxo. Cabe ressaltar que a escala supracitada não foi validada no Brasil, o que justifica a escolha da escala de dimensões de personalidade de marca validada para o contexto brasileiro (MUNIZ; MARCHETTI, 2012).

No que se refere às críticas e limitações da escala de personalidade de marca (AAKER, 1997), Malik e Naeem, (2012) discutem o fato de a mesma considerar apenas os atributos positivos da marca, em contraposição ao modelo Big Five de onde se origina e que engloba traços de personalidade tanto positivos quanto negativos. Malik e Naeem (2012) apontam ainda que alguns traços de personalidade que compõem os itens da escala não foram considerados traços de personalidade propriamente ditos. 
Neste sentido, Geuens, Weijters e Wulf (2009) desenvolveram na Bélgica uma escala de personalidade de marca, compreendendo apenas itens de personalidade, excluindo quaisquer itens que pudessem identificar idade ou gênero, com foco apenas nos itens relacionados à personalidade humana. Os autores identificaram cinco dimensões de personalidade de marca, com os adjetivos que as representam: (1) Responsability ou responsabilidade, representada pelos adjetivos prática ou realista, estável e responsável; (2) Activity ou atividade, representada pelos adjetivos dinâmica e inovadora; (3) Aggressiveness ou agressividade, cujos adjetivos que a representam são ousado e corajoso; (4) Simplicity ou simplicidade, representada por comum e simples; e (5) Emotionality ou emotividade, com os adjetivos romântica e sentimental. O estudo mostra que as dimensões são confiáveis e válidas dentro do contexto pesquisado e que a escala pode ser usada para estudos com diferentes marcas e categorias de produtos, contudo, não foram encontrados outros estudos aplicando a escala de Geuens, Weijters e Wulf (2009), especialmente no que tange a sua validação em outros países.

Não obstante, no artigo em que desenvolveu a escala, a própria Aaker (1997) afirma que a personalidade de uma marca é composta por traços de personalidade sim, mas também engloba características demográficas como sexo, idade e classe social, lembrando ainda, em consonância com Carprara, Barbaranelli e Guido (2001), que os diversos atributos da personalidade humana podem de fato auxiliar na construção da personalidade de marca, mas de maneira limitada.

Apesar de concordarem que os consumidores percebem as marcas por meio de características atribuídas e elas e que esta percepção é relevante à construção e gerenciamento de marcas, Azoulay e Kapferer (2003) questionaram a definição do construto personalidade de marca, a saber, "o conjunto de características humanas associadas a uma marca" (AAKER, 1997, p. 347). Para Azoulay e Kapferer (2003), este conceito representa uma parte, e não o todo, como deveria, destacando que valores internos, traços físicos e o imaginário do usuário típico também podem ser consideradas características humanas, podendo assim, associaremse a marcas. Assim, os autores apontam para o risco de confusão conceitual. Vale ressaltar que a crítica não se refere à construção da escala, mas sim à validade do construto.

Posto isso, Azoulay e Kapferer (2003) sugerem uma definição do conceito de personalidade de marca, delineando o que está incluso e o que está excluso do conceito: "personalidade de marca é o conjunto de traços da personalidade humana que são aplicáveis e relevantes às marcas" (AZOULAY; KAPFERER, 2003, p. 151). Os autores propõem então 
que a personalidade de marca deva ser estudada através do modelo Big Five, proposto por Goldberg (1990), já que ele é um construto da psicologia, e, mesmo que esteja sendo usado em outra área de conhecimento, deveria manter-se fiel à perspectiva que o origina.

Uma vez que Azoulay e Kapferer (2003) propõem a aplicação do modelo Big Five (GOLDBERG, 1990) para a mensuração do construto personalidade de marca, e Aaker (1997) avalia que o construto deve ser medido por uma escala específica, Pontes e Parente (2008) propuseram-se a testar e comparar a aplicação das duas escalas, de maneira a identificar a escala mais eficiente com o objetivo de identificar a personalidade de marca. Os resultados confirmaram que a medida proposta por Aaker (1997), apesar de suas limitações já discutidas, consiste em uma ferramenta mais adequada (PONTES; PARENTE, 2008) para aferição da personalidade de marca. Segundo os autores, a pesquisa revelou que a ferramenta de Aaker (1997) representa corretamente a percepção do consumidor quanto à essência da marca, quando comparara à ferramenta defendida por Azoulay e Kapferer (2003). Ressaltam, ainda, que o conceito de personalidade de marca de Aaker (1997) atende os requisitos para a avaliação de como o consumidor percebe ou entende uma marca, e que este conhecimento é o ponto de partida para decisões estratégicas de comunicação, reposicionamento ou direcionamento da marca, fundamentais para a manutenção da competitividade das empresas.

Neste sentido, Eisend e Stokburger-Sauer (2013) investigaram as características das medidas utilizadas nas dimensões de personalidade de marca (AAKER, 1997), com o objetivo de identificar as intercorrelações e confiabilidades em todas as suas cinco dimensões. Os resultados mostram a estabilidade das dimensões de personalidade de marca e apoiam a transferência dos fatores de personalidade do modelo Big Five (GOLDBERG, 1990) para domínios não humanos, conforme proposto por Aaker (1997).

Muniz e Marchetti (2012) apresentaram duas motivações para a validação de uma escala de personalidade de marca no contexto brasileiro: (1) a ausência de estudos e artigos explorando o assunto na realidade nacional e (2) a relevância das diferenças culturais na percepção das marcas para os consumidores. Conforme os autores, a personalidade de marca pode ser entendida como um conjunto de valores consolidados com a marca ao longo do tempo, que podem auxiliar na diferenciação quando existe paridade em relação aos aspectos tangíveis ou funcionais.

O estudo de validação da escala original de Aaker (1997) no Brasil foi dividido em duas etapas. A primeira, consistindo em uma etapa preparatória, englobou a tradução dos itens da escala e entrevistas em profundidade com pesquisadores e profissionais, gerando uma lista 
final de 174 traços de personalidade. Visando filtrar o conjunto de traços obtido, de forma a reduzi-lo a um volume administrável, os autores realizaram a aplicação de um questionário a profissionais e professores da área de marketing, para avaliar o quanto cada traço descrevia uma marca. Com este procedimento, um instrumento composto por 87 características foi obtido.

A segunda etapa voltou-se à aplicação da escala resultante da primeira etapa ao consumidor final. Foram selecionadas 24 marcas nacionais e globais, pertencentes a 12 diferentes categorias de produtos e serviços tais quais produtos de higiene, limpeza, alimentos, bebidas, calçados, automóveis e aparelhos celulares, e uma categoria de serviços, representada por bancos. A amostra final foi composta por 1.302 questionários válidos. Os resultados obtidos permitiram a identificação de cinco dimensões de personalidade de marca no contexto brasileiro, a saber, Credibilidade, Diversão, Audácia, Sofisticação e Sensibilidade. Segundo Muniz e Marchetti (2012), as cinco dimensões encontradas representam 46,75\% da variância explicada do construto e os alfas de Cronbach para medição de precisão ou confiabilidade obtidos variaram entre 0,82 a 0,92 nas cinco dimensões.

A primeira dimensão identificada foi Credibilidade, apresentando 14,41\% de variância explicada e alfa de Cronbach de 0,93. Esta dimensão reflete facetas como responsável, segura, confiável, correta, respeitável, leal e consistente (MUNIZ; MARCHETTI, 2012, p. 180). Para os autores, as marcas que apresentam tais características apresentam excelente relacionamento com o consumidor, já que configuram opções sólidas por mostrarem-se marcas confiáveis, respeitáveis e ligadas ao sucesso.

A segunda dimensão foi Diversão, com variância explicada de $13,53 \%$ e alfa 0,91 . Tal dimensão é representada por facetas como legal, feliz, festiva, extrovertida, divertida, bemhumorada e brincalhona (MUNIZ; MARCHETTI, 2012, p. 180). Segundo os autores, tais características descrevem uma marca que possui a simpatia dos consumidores, revelando uma relação mais informal entre marca e consumidor, onde a comunicação é feita de maneira descontraída.

A terceira dimensão identificada recebeu a denominação Audácia, cuja variância explicada é $8,09 \%$ e alfa 0,89 . Suas facetas são definidas como moderna, ousada, criativa e atualizada (MUNIZ; MARCHETTI, 2012, p. 180). Os autores sugerem que marcas com tais características tendem a apresentar inovações e evolução contínua ao longo do relacionamento com o consumidor, liderando a preferência devido a ofertas de produto criativas e uma comunicação mais agressiva. 
A quarta dimensão foi Sofisticação, apresentando variância explicada de 5,75\% e alfa de Cronbach 0,90 e englobando as facetas chique, alta-classe, elegante, sofisticada e glamorosa (MUNIZ; MARCHETTI, 2012, p. 180). De acordo com os autores, as marcas dentro desta dimensão refletem alto padrão e requinte, oferecendo uma imagem aspiracional, uma vez que os consumidores desejam ter estas características, mas muitas vezes não têm.

Por fim, a quinta dimensão identificada foi Sensibilidade, com variância explicada de 4,96\% e alfa 0,82, refletindo as facetas delicada, sensível, romântica e encantadora (MUNIZ; MARCHETTI, 2012, p. 181). Os autores argumentam, ainda, que uma marca cuja personalidade é descrita pela sensibilidade é aquela que se preocupa com o consumidor, cultivando laços emocionais com os clientes.

O Quadro 2 descreve as dimensões de personalidade de marca identificadas no contexto brasileiro com os adjetivos que as compõem, propostas por Muniz e Marchetti (2012).

Quadro 2 - Escala de Dimensões de Personalidade de Marca no Contexto Brasileiro

\begin{tabular}{|l|l|l|l|l|}
\hline \multicolumn{5}{|c|}{ PERSONALIDADE DE MARCA } \\
\hline CREDIBILIDADE & ALEGRIA & AUDÁCIA & SOFISTICAÇÃO & SENSIBILIDADE \\
\hline Responsável & Legal & Moderna & Chique & Romântica \\
Segura & Feliz & Ousada & Elegante & Delicada \\
Confiável & Festiva & Criativa & Alta-classe & Sensitiva \\
Confidente & Extrovertida & Atualizada & Sofisticada & Encantadora \\
Correta & Divertida & & Glamorosa & \\
Respeitável & Bem-humorada & & & \\
Leal & Brincalhona & & & \\
Consistente & & & & \\
\hline
\end{tabular}

Fonte: Muniz e Marchetti (2012) (tradução da autora)

Muniz e Marchetti (2012) atentam ainda para a necessidade de comparação entre as diferentes dimensões de personalidade de marca resultantes dos estudos que validaram a escala em países distintos (AAKER, 1997; AAKER; BENET-MARTINEZ; GAROLERA, 2001). Assim, os dados expostos pelo Quadro 3 têm a função de demonstrar e comparar os resultados obtidos nos estudos supracitados com a escala brasileira (MUNIZ; MARCHETTI, 2012). 
Quadro 3 - Comparação entre as dimensões de personalidade de marca no Brasil e em outros contextos

\begin{tabular}{|c|c|c|c|}
\hline \multicolumn{4}{|c|}{$\begin{array}{c}\text { COMPARAÇÃO ENTRE AS DIMENSÕES DE PERSONALIDADE DE MARCA NO BRASIL E EM } \\
\text { OUTROS CONTEXTOS }\end{array}$} \\
\hline BRASIL & ESTADOS UNIDOS & JAPÃO & ESPANHA \\
\hline CREDIBILIDADE & COMPETÊNCIA & COMPETÊNCIA & PAIXÃO \\
\hline $\begin{array}{l}\text { Traços: leal, consistente, } \\
\text { correta, confidente e } \\
\text { respeitável }\end{array}$ & $\begin{array}{l}\text { Traços: confiável, } \\
\text { inteligente, técnica, bem- } \\
\text { sucedida, líder, confidente } \\
\text { e convicta }\end{array}$ & $\begin{array}{l}\text { Traços: consistente, } \\
\text { responsável, confidente, } \\
\text { masculina, paciente }\end{array}$ & $\begin{array}{l}\text { Traços: intensa, espiritual, } \\
\text { mística e boêmia }\end{array}$ \\
\hline ALEGRIA & SINCERIDADE & SINCERIDADE & SINCERIDADE \\
\hline $\begin{array}{l}\text { Traços: feliz, } \\
\text { extrovertida, festiva, } \\
\text { divertida }\end{array}$ & $\begin{array}{l}\text { Traços: realista, familiar, } \\
\text { honesta, amigável e } \\
\text { sincera }\end{array}$ & $\begin{array}{l}\text { Traços: querida, amável e } \\
\text { atenta }\end{array}$ & $\begin{array}{l}\text { Traços: correta, atenta, } \\
\text { sincera e realista }\end{array}$ \\
\hline AUDÁCIA & EXCITAÇÃO & EXCITAÇÃO & EXCITAÇÃO \\
\hline $\begin{array}{l}\text { Traços: ousada, } \\
\text { atualizada, moderna e } \\
\text { criativa }\end{array}$ & $\begin{array}{l}\text { Traços: ousada, moderna, } \\
\text { agitada, jovem, } \\
\text { espirituosa e imaginativa }\end{array}$ & $\begin{array}{l}\text { Traços: divertida, falante, } \\
\text { otimista, amigável, } \\
\text { espirituosa e } \\
\text { contemporânea }\end{array}$ & $\begin{array}{l}\text { Traços: querida, } \\
\text { extrovertida, ousada, } \\
\text { jovem e imaginativa }\end{array}$ \\
\hline SOFISTICAÇÃO & SOFISTICAÇÃO & SOFISTICAÇÃO & SOFISTICAÇÃO \\
\hline $\begin{array}{l}\text { Traços: chique, alta- } \\
\text { classe, elegante e } \\
\text { sofisticada }\end{array}$ & $\begin{array}{l}\text { Traços: alta-classe, } \\
\text { glamorosa, atraente e } \\
\text { feminina }\end{array}$ & $\begin{array}{l}\text { Traços: elegante, } \\
\text { romântica, chique, } \\
\text { sofisticada e extravagante }\end{array}$ & $\begin{array}{l}\text { Traços: glamorosa, } \\
\text { chique, elegante, } \\
\text { confidente e líder }\end{array}$ \\
\hline SENSIBILIDADE & ROBUSTEZ & TRANQUILIDADE & TRANQUILIDADE \\
\hline $\begin{array}{l}\text { Traços: delicada, sensível } \\
\text { e romântica }\end{array}$ & $\begin{array}{l}\text { Traços: aventureira, } \\
\text { masculina, firme e } \\
\text { robusta }\end{array}$ & $\begin{array}{l}\text { Traços: tímida, doce, } \\
\text { dependente e infantil }\end{array}$ & $\begin{array}{l}\text { Traços: afeituosa, doce, } \\
\text { amável e tranquila }\end{array}$ \\
\hline
\end{tabular}

Fonte: Muniz e Marchetti (2012) (tradução da autora)

A partir da validação da Escala de Dimensões de Personalidade de Marca no Contexto Brasileiro por Muniz e Marchetti (2005; 2012), outros estudos foram realizados quanto a esta temática. Battistella, Bichueti e Grohmann (2011) conduziram um estudo em uma marca de calçados com o objetivo de identificar a percepção dos clientes em relação à marca de calçados especifica. Os resultados revelaram que a principal dimensão percebida pelos clientes é a dimensão credibilidade, seguida das dimensões audácia e sofisticação. Por fim, o estudo de Leão, Camargo e Cavalcanti (2013) foi conduzido sob o objetivo de identificar o perfil de uma marca de moda praia na visão dos seus consumidores por meio da abordagem qualitativa. Os resultados demonstraram implicações teóricas sobre a relação marca e consumidores, onde os autores destacam a geração de insights úteis à estratégia de posicionamento. 
Tendo em vista os resultados expostos e os bons índices psicométricos obtidos, a Escala de Dimensões de Personalidade de Marca, validada por Muniz e Marchetti (2012) para o contexto brasileiro, será o instrumento utilizado para mensurar a personalidade de marca no presente estudo.

\subsubsection{Personalidade de Marca: Revisão da Produção Nacional}

Esta seção abordará uma síntese da revisão da produção nacional, por meio de análise bibliométrica realizada no período compreendido entre 2010 e 2015, de forma a ilustrar o panorama da pesquisa em personalidade de marca no Brasil. A bibliometria, como área de estudo da Ciência da Informação, tem um papel relevante na análise da produção científica de um país, uma vez que retrata o comportamento e desenvolvimento de uma área do conhecimento ao apontar lacunas teóricas e empíricas, quantificando as características existentes nos estudos (ARAÚJO; ALVARENGA, 2011).

O levantamento bibliométrico consistiu em uma pesquisa nos principais periódicos científicos brasileiros de primeira linha em Administração e Psicologia, sob classificação maior ou igual a B1 pelo sistema Qualis da Coordenação de Aperfeiçoamento de Pessoal de Nível Superior - CAPES. Este corte em B1 justifica-se por ser o critério utilizado pela maioria dos programas de pós-graduação nas áreas para computação de produção de primeira linha. Para a área de administração, 27 periódicos atenderam a esta classificação, tal qual mostra a Tabela 1. 
Tabela 1 - Lista de periódicos selecionados em Administração

\begin{tabular}{|c|c|c|}
\hline Número & Título do Periódico & $\begin{array}{c}\text { Classificação } \\
\text { Qualis }\end{array}$ \\
\hline 1 & BAR - Brazilian Administration Review & $\mathrm{A} 2$ \\
\hline 2 & BBR - Brazilian Business Review & $\mathrm{A} 2$ \\
\hline 3 & Cadernos EBAPE.BR & $\mathrm{A} 2$ \\
\hline 4 & Desenvolvimento em questão (Unijuí) & $\mathrm{A} 2$ \\
\hline 5 & Economia Global e Gestão & $\mathrm{A} 2$ \\
\hline 6 & Faces: Revista de Administração & $\mathrm{A} 2$ \\
\hline 7 & Gestão \& Produção (UFSCAR) & A2 \\
\hline 8 & Gestão \& Regionalidade & $\mathrm{A} 2$ \\
\hline 9 & Organizações \& Sociedade & B1 \\
\hline 10 & Organizações Rurais e Agroindustriais (UFLA) & B1 \\
\hline 11 & RAC - Revista de Administração Contemporânea & B1 \\
\hline 12 & RAE - Revista de Administração de Empresas & B1 \\
\hline 13 & RAI - Revista de Administração e Inovação & B1 \\
\hline 14 & RAM. Revista de Administração Mackenzie & $\mathrm{B} 1$ \\
\hline 15 & ReA UFSM & B1 \\
\hline 16 & REAd. Revista Eletrônica de Administração & $\mathrm{B} 1$ \\
\hline 17 & Revista Brasileira de Gestão de Negócios & B1 \\
\hline 18 & Revista Brasileira de Gestão e Desenvolvimento Regional & B1 \\
\hline 19 & Revista de Administração & B1 \\
\hline 20 & Revista de Administração da Unimep & $\mathrm{B} 1$ \\
\hline 21 & Revista de Administração Pública & $\mathrm{B} 1$ \\
\hline 22 & Revista de Ciências da Administração & $\mathrm{B} 1$ \\
\hline 23 & Revista de Contabilidade e Organizações & $\mathrm{B} 1$ \\
\hline 24 & Revista de Gestão da Tecnologia e Sistemas de Informação & B1 \\
\hline 25 & Revista Encontros Cientificos: tourism and management studies & $\mathrm{B} 1$ \\
\hline 26 & Revista Portuguesa e Brasileira de Gestão & B1 \\
\hline 27 & Revista USP & B1 \\
\hline
\end{tabular}

Fonte: Elaborada pela autora

Como o conceito de personalidade de marca teve suas origens em estudos da psicologia (GARDNER; LEVY, 1955; MARTINEU, 1958; PLUMMER, 1985; BERRY, 1988; DURGEE, 1988), resolveu-se fazer a busca também nos periódicos desta área. Posto isto, foram selecionados 39 periódicos, segundo o mesmo critério de classificação Qualis CAPES, conforme apresenta a Tabela 2. 
Tabela 2 - Lista de periódicos selecionados em Psicologia

\begin{tabular}{|c|c|c|}
\hline Número & Título do Periódico & $\begin{array}{c}\text { Classificação } \\
\text { Qualis }\end{array}$ \\
\hline 1 & Paidéia (USP. Ribeirão Preto. Impresso) & A1 \\
\hline 2 & Psicologia: Reflexão e Crítica & A1 \\
\hline 3 & Psicologia: Reflexão e Crítica (UFRGS. Impresso) & A1 \\
\hline 4 & Psicologia: Teoria e Pesquisa (Brasília. Online) & A1 \\
\hline 5 & Psicologia: Teoria e Pesquisa (UnB. Impresso) & A1 \\
\hline 6 & Estudos de Psicologia (Natal. Online) & A2 \\
\hline 7 & Estudos de Psicologia (PUCCAMP. Impresso) & A2 \\
\hline 8 & Estudos de Psicologia (UFRN) & A2 \\
\hline 9 & Interação em Psicologia (Impresso) & A2 \\
\hline 10 & Interação em Psicologia (Online) & A2 \\
\hline 11 & Psico (PUCRS. Impresso) & A2 \\
\hline 12 & Psico (PUCRS. Online) & A2 \\
\hline 13 & Psicologia \& Sociedade (Online) & A2 \\
\hline 14 & Psicologia e Sociedade (Impresso) & A2 \\
\hline 15 & Psicologia em Estudo (Impresso) & A2 \\
\hline 16 & Psicologia em Estudo (Online) & A2 \\
\hline 17 & Psicologia USP (Impresso) & $\mathrm{A} 2$ \\
\hline 18 & Psicologia USP (Online) & A2 \\
\hline 19 & Psicologia: Ciência e Profissão (Impresso) & A2 \\
\hline 20 & Psicologia: Ciência e Profissão (Online) & $\mathrm{A} 2$ \\
\hline 21 & Psicologia: Teoria e Prática (Impresso) & $\mathrm{A} 2$ \\
\hline 22 & Psico-USF (Impresso) & A2 \\
\hline 23 & Revista de Psicologia : Teoria e Prática (Online) & $\mathrm{A} 2$ \\
\hline 24 & Revista Latinoamericana de Psicologia & A2 \\
\hline 25 & Análise Psicológica & $\mathrm{B} 1$ \\
\hline 26 & Anuário de Psicologia & B1 \\
\hline 27 & Avaliação Psicológica (Impresso) & B1 \\
\hline 28 & Avaliação Psicológica (Online) & B1 \\
\hline 29 & Estudos e Pesquisas em Psicologia (UERJ. Impresso) & $\mathrm{B} 1$ \\
\hline 30 & Fractal: Revista de Psicologia & B1 \\
\hline 31 & Psicologia Clínica (PUCRJ. Impresso) & B1 \\
\hline 32 & Psicologia em Revista (Impressa) & $\mathrm{B} 1$ \\
\hline 33 & Psicologia em Revista (Online) & $\mathrm{B} 1$ \\
\hline 34 & Psicologia Escolar e Educacional (Impresso) & B1 \\
\hline 35 & Psicologia, Saúde \& Doenças & B1 \\
\hline 36 & Revista de Psicología (Lima) & B1 \\
\hline 37 & Revista de Psicología Social (Ed. Impr.) & $\mathrm{B} 1$ \\
\hline 38 & Revista Psicologia: Organizações e Trabalho & B1 \\
\hline 39 & Terapia Psicológica (Impresa) & B1 \\
\hline
\end{tabular}

Fonte: Elaborada pela autora 
Desta forma, o levantamento bibliométrico teve como fonte de pesquisa um total de 56 periódicos, somando-se os periódicos selecionados na área de administração e psicologia. Em seguida, buscou-se artigos que compreendessem, nos títulos, resumos ou palavras-chave, os seguintes termos: personalidade "de" marca, personalidade "da" marca e brand personality.

Esta busca resultou em apenas quatro artigos no período analisado, que foram, na sequência, analisados com o objetivo de confirmar se os estudos de fato contemplavam personalidade de marca, ou apenas citavam o termo em seu texto. Todos os artigos selecionados cumpriram os requisitos; logo, a revisão da produção nacional aqui apresentada analisa um volume total de quatro artigos. Importante salientar que todos os artigos são oriundos de periódicos da área de administração, uma vez que não foram encontrados artigos sobre o tema personalidade de marca nos periódicos da psicologia.

Assim, os artigos selecionados foram categorizados e analisados de acordo com os seguintes parâmetros: (1) nome do periódico, (2) ano de publicação, (3) enquadramento do estudo, a saber, estudos teórico-empíricos ou ensaios teóricos, (4) instituições de origem dos autores dos estudos, (5) autores que mais publicaram no período e, por fim, (6) assuntos mais estudados dentro do tema Personalidade de Marca. Neste último aspecto, de acordo com a categorização dos estudos em personalidade de marca proposta por Azoulay (2005), os artigos selecionados foram classificados, quanto ao tema, em (a) congruência entre personalidade de marca e personalidade do consumidor, (b) impacto no comportamento de compra e (c) desenvolvimento e validação de instrumentos, visando contemplar os artigos que propuseram à construção de novos instrumentos de pesquisa.

A classificação relativa ao enquadramento dos estudos exige, ainda, que os artigos identificados como teórico-empíricos sejam analisados sob outros critérios, quais sejam, (7) natureza do estudo, dividida entre quantitativa, qualitativa ou multimétodo, (8) setor da economia das empresas pesquisadas, onde o $1^{\circ}$ setor refere-se às organizações públicas, o $2^{\circ}$ setor contempla as empresas privadas e o $3^{\circ}$ setor engloba as organizações nãogovernamentais, (9) ramo de atuação das empresas pesquisadas, (10) instrumentos de coleta de dados utilizados pelo pesquisador e (11) técnicas de análise de dados utilizadas para a realização das pesquisas. $\mathrm{O}$ Quadro 4 mostra o resultado da presente pesquisa referente à produção nacional quanto à personalidade de marca, devidamente identificada nas categorias de análise supracitadas. 
Quadro 4 - Categorização dos artigos de Personalidade de Marca

\begin{tabular}{|c|c|c|c|c|}
\hline & \multicolumn{4}{|c|}{ Artigos } \\
\hline & PM 1 & PM 2 & PM 3 & PM 4 \\
\hline Nome do Periódico & FACES & BAR & BBR & REAd \\
\hline Ano de Publicação & 2011 & 2012 & 2013 & 2014 \\
\hline Autor & $\begin{array}{l}\text { Valter Afonso } \\
\text { Vieira }\end{array}$ & $\begin{array}{c}\text { Karlan Muller } \\
\text { Muniz, Renato } \\
\text { Zancan Marchetti }\end{array}$ & $\begin{array}{c}\text { André Luiz } \\
\text { Maranhão de } \\
\text { Souza Leão, } \\
\text { Thiago Ianatoni } \\
\text { Camargo, Rodrigo } \\
\text { César Tavares } \\
\text { Cavalcanti }\end{array}$ & $\begin{array}{c}\text { André Luiz } \\
\text { Maranhão de } \\
\text { Souza Leão, } \\
\text { Thiago Ianatoni } \\
\text { Camargo, Rodrigo } \\
\text { César Tavares } \\
\text { Cavalcanti }\end{array}$ \\
\hline $\begin{array}{l}\text { Instituição de } \\
\text { Origem }\end{array}$ & UnB & PUC/PR & UFPE & UFPE \\
\hline $\begin{array}{l}\text { Enquadramento } \\
\text { do Estudo }\end{array}$ & Teórico-empírico & Teórico-empírico & Teórico-empírico & Teórico-empírico \\
\hline $\begin{array}{l}\text { Natureza da } \\
\text { Pesquisa }\end{array}$ & Quantitativa & Multimétodo & Qualitativa & Qualitativa \\
\hline $\begin{array}{c}\text { Técnica de Coleta } \\
\text { de Dados }\end{array}$ & Questionário & $\begin{array}{l}\text { Entrevista, } \\
\text { Questionário }\end{array}$ & Entrevista & Entrevista \\
\hline $\begin{array}{c}\text { Técnica de Análise } \\
\text { de Dados }\end{array}$ & $\begin{array}{l}\text { Análise Fatorial } \\
\text { Exploratória }\end{array}$ & $\begin{array}{c}\text { Análise de } \\
\text { Conteúdo, Análise } \\
\text { Fatorial } \\
\text { Exploratória } \\
\end{array}$ & $\begin{array}{l}\text { Análise do } \\
\text { Discurso }\end{array}$ & $\begin{array}{l}\text { Análise do } \\
\text { Discurso }\end{array}$ \\
\hline Tema Pesquisado & $\begin{array}{l}\text { Impacto no } \\
\text { Comportamento } \\
\text { de Compra }\end{array}$ & $\begin{array}{l}\text { Desenvolvimento de } \\
\text { Validação de } \\
\text { Instrumento }\end{array}$ & $\begin{array}{c}\text { Impacto no } \\
\text { Comportamento de } \\
\text { Compra }\end{array}$ & $\begin{array}{c}\text { Impacto no } \\
\text { Comportamento de } \\
\text { Compra }\end{array}$ \\
\hline
\end{tabular}

Fonte: Elaborado pela autora

No que se refere aos periódicos, apenas quatro periódicos apresentaram publicações sobre personalidade de marca, a saber, a Brazilian Business Review, a Revista FACES, a Revista Eletrônica de Administração - REAd e a Brazilian Administration Review - BAR.

O período contemplado pela análise bibliométrica apresentou poucos estudos, sendo que em 2010 nenhum estudo foi encontrado. A partir de 2011, é possível identificar esforços nesta linha, ainda que seja perceptível a lacuna de pesquisa no tocante à personalidade de marca, visto que foi publicado apenas um artigo por ano entre 2011 e 2014 . O ano de 2015 também não apresentou resultados. 
No que tange ao enquadramento dos estudos, observa-se a preponderância de trabalhos teórico-empíricos, visto que contemplam $100 \%$ do volume analisado.

Quanto às instituições de origem dos autores dos estudos, a instituição que mais publicou artigos foi a Universidade Federal de Pernambuco, com dois artigos publicados no período. As outras instituições de origem dos autores de estudos no tema foram a UnB e a PUC/PR. Entre os trabalhos identificados, alguns autores tiveram destaque ao publicar mais de um artigo dentro do período analisado, destacando-se André Luiz Maranhão de Souza Leão, Thiago Ianatoni Camargo e Rodrigo César Tavares Cavalcanti, todos pertencentes à UFPE e com duas publicações no período.

No que se refere à classificação dos assuntos abordados dentro do tema personalidade de marca, houve predominância de artigos na categoria "impacto no comportamento de compra", com três artigos. Apenas um dos artigos encontrados foi classificado em "desenvolvimento e validação de instrumento". Revela-se, ainda, que nenhum artigo visou estudar a congruência entre a personalidade do consumidor e a personalidade de marca, o que ratifica o que foi colocado no referencial teórico quanto a esta vertente ser uma linha de pesquisa mais afeta à psicologia.

No que se refere aos trabalhos de enquadramento teórico-empírico, observou-se a prevalência de artigos de abordagem qualitativa, com dois estudos nesta linha. Apenas um estudo de natureza quantitativa foi encontrado, sendo que o mesmo ocorreu com os estudos de abordagem multimétodo, ou seja, que mesclaram métodos qualitativos e quantitativos (qualiquanti). Cabe salientar que todos os artigos teórico-empíricos foram realizados em empresas privadas, ou seja, no $2^{\circ}$ setor da economia. Entre as empresas pesquisadas, teve destaque o ramo do vestuário, com dois estudos. O ramo educacional foi alvo de um dos estudos e, por fim, um artigo foi realizado contemplando uma série de ramos de atuação, que foram descritos como "vários".

No que se refere aos instrumentos de coleta de dados, visto que a análise realizada contempla diferentes abordagens de pesquisa, observou-se que os pesquisadores utilizaram diversos instrumentos de coleta de dados para a realização de seus trabalhos nas organizações pesquisadas. A entrevista foi o instrumento de coleta de dados mais utilizado entre os artigos analisados, seguida pelo o questionário. Quanto à técnica de análise dos dados, foram identificadas análise fatorial exploratória, análise de discurso e análise de conteúdo.

A partir das informações levantadas, observou-se que o estudo da temática personalidade de marca ainda é incipiente no cenário brasileiro de pesquisa, visto que os 
periódicos em administração, nos últimos cinco anos, publicaram apenas quatro estudos sobre o tema e os da psicologia nada publicaram. Em uma busca mais ampla, foi encontrado um único artigo publicado em 2009 na RAE Eletrônica, que buscou investigar a relação entre a personalidade de marca e a previsão de hábitos de consumo de moda esportiva, tendo revelado a relação entre os construtos (MONTEIRO; VEIGA; GONÇALVES, 2009).

Posto que se trata de um tema relevante por sua contribuição prática aos gestores organizacionais e pela lacuna identificada na literatura, recomenda-se, aos periódicos, chamadas de artigos sobre o tema, de forma a incentivar a pesquisa na temática.

Os resultados referentes ao enquadramento dos estudos podem ser analisados sob duas perspectivas. Primeiramente, os resultados incitam o desenvolvimento de estudos teóricos capazes de trabalhar os conceitos e de consolidar o tema, criando um arcabouço teórico que sustente futuras pesquisas empíricas. Por outro lado, tais resultados clamam por mais trabalhos capazes de demonstrar empiricamente o impacto da personalidade de marca, incitando estudos que relacionem o construto a outras variáveis, de forma a desenvolver o campo de pesquisa em comportamento do consumidor.

No que tange os assuntos mais estudados, observa-se a ausência de artigos relacionados à congruência entre a personalidade do consumidor e personalidade de marca, contrariando os achados em pesquisas internacionais, onde esta linha de pesquisa é bastante vigorosa, porém restringe-se à área da psicologia. É importante ressaltar também a relevância de estudos voltados à construção de novos instrumentos de pesquisa, especialmente com a finalidade de mensurar construtos, favorecendo os testes empíricos e os estudos relacionais e, sob uma perspectiva gerencial, viabilizando diagnósticos organizacionais.

Outrossim, pesquisas multimétodo, as quais mesclam abordagens qualitativas e quantitativas, possibilitando uma triangulação metodológica, são importantes e necessárias por permitirem uma melhor compreensão do fenômeno em estudo ao mesmo tempo em que esforços para mensurá-lo são engendrados.

\subsubsection{Institucionalização da Pesquisa em Personalidade de Marca}

A busca realizada no diretório de grupos de pesquisa da Base de Dados Lattes do CNPq (Conselho Nacional de Desenvolvimento Científico e Tecnológico), sob os temas personalidade "de" marca e personalidade "da" marca não revelou nenhum grupo de pesquisa no Brasil direcionado ao estudo deste construto. 
O quadro teórico conceitual construído para personalidade de marca permite avaliar a relevância do tema, tanto na área gerencial como na pesquisa acadêmica, o que fica evidente com o volume de artigos publicados, especialmente no que tange ao desenvolvimento de instrumentos de pesquisa válidos. Outra fonte de debate reside na necessidade de contextualização do conceito para diferentes culturas. Cabe ressaltar que é um tema de relevância global, visto a amplitude das pesquisas e do número de validações em países distintos. Ainda, é apontada a possibilidade de contextualizá-lo em uma perspectiva micro, onde a escala se torna disponível para mensuração de personalidade de marca em indústrias específicas.

Posto isto, para fins deste trabalho, utilizou-se o conceito de personalidade de marca que dá origem à escala a ser utilizada para mensuração do construto no contexto brasileiro, a saber, “o conjunto de características humanas associadas a uma marca” (AAKER, 1997, p. 347). A definição proposta pela autora explica a atribuição de traços da personalidade humana no contexto das marcas, permitindo que tais traços sejam identificados e estes, por sua vez, permitam o desenvolvimento de estudos relacionais como o que aqui se propõe e o desenho de estratégias de posicionamento de marca mais eficientes e lucrativas como implicação gerencial. 


\subsection{MARKETING DE RELACIONAMENTO (CRM)}

A seção que se inicia contempla o estado da arte sobre CRM, a revisão da produção nacional entre os anos de 2010 e 2015 e a institucionalização da pesquisa sobre o tema.

\subsubsection{Marketing de Relacionamento: Estado da Arte}

As organizações bem-sucedidas no mercado global são normalmente firmas capazes de demonstrar capacidade de resposta de forma rápida e inovação flexível de produtos, em interação com capacidades gerenciais de coordenação e exploração de competências internas e externas (TEECE; PISANO; SHUEN, 1997). Tais organizações apresentam vantagens competitivas que as distinguem de seus competidores, contexto em que vantagem competitiva é entendida como um conjunto de ações integradas que produzem vantagem sustentável sobre os concorrentes (COYNE, 1986). Nesta perspectiva, a vantagem competitiva apresenta-se como resultado da capacidade da organização em realizar de forma eficiente suas atividades, seja por meio da obtenção de um custo menor que o dos concorrentes ou ainda através de uma forma única de organizar suas capacidades e atividades internas, que não possa ser copiada pelos concorrentes e que seja capaz de gerar um valor diferenciado para os clientes (PORTER, 1991).

Hoffman (2000) afirma que a vantagem competitiva sustentável pode ser conquistada por meio do estabelecimento de vínculos entre empresas e consumidores, bem como através do conhecimento adquirido sobre as preferências dos clientes. Observa-se, desta forma, que as organizações têm se desprendido das perspectivas associadas unicamente à lucratividade e ao market share, ou parcela de mercado, voltando-se para a perspectiva dos consumidores, onde fenômenos como satisfação e lealdade dos clientes passam a ser elementos centrais nas estratégias competitivas (DAY; WENSLEY, 1988). Assim, o consumidor passa a exercer um papel fundamental nas atividades organizacionais, evidenciando a necessidade da construção de um relacionamento entre consumidor e empresa em nome da obtenção de melhores resultados organizacionais (BHARADWAJ; VARADARAJAN; FAHY, 1993).

Berry (1995), um dos autores pioneiros na pesquisa sobre marketing de relacionamento, considera que conquistar um cliente é apenas uma parte do processo de marketing. Para o autor, as bases do marketing, dentro do contexto apresentado, devem ter foco em solidificar o relacionamento, transformar clientes indiferentes em clientes leais e tornar consumidores em clientes. 
Observa-se, assim, uma mudança de paradigma dos conceitos de marketing, saindo de uma orientação voltada para a conquista de clientes e voltando-se à orientação com foco na retenção ou lealdade dos clientes, representada pelo marketing de relacionamento (SHETH; PARVATIYAR, 2002; PAYNE, 2006; GRONROOS, 2009). Neste sentido, Kumar, Jones, Venkatesan e Leone (2011) conduziram um estudo com o objetivo de verificar a relação entre orientação de mercado e vantagem competitiva sustentável, cujo resultado revelou um efeito positivo da orientação para o mercado no desempenho do negócio, tanto a curto quanto a longo prazo.

Quanto à sua definição, marketing de relacionamento consiste em um esforço integrado das organizações com o objetivo de identificar, construir e desenvolver relacionamentos a longo prazo com os clientes (BERRY, 1983; PARVATIYAR; SHETH, 2000). Para McKenna (1999), o marketing de relacionamento sugere a construção e manutenção do relacionamento com clientes, revelando uma ligação de longo prazo, que tem por objetivo a fidelização do consumidor e a otimização de indicadores organizacionais. $\mathrm{O}$ autor revela ainda que o marketing de relacionamento se apresenta como uma resposta das organizações às condições de competividade do mercado, integrando os clientes às suas atividades, extraindo desse relacionamento informações que irão permitir a obtenção de vantagens competitivas.

Mishra e Mishra (2009) defendem que o relacionamento com os clientes ajuda as empresas a gerenciarem de maneira efetiva as interações com os consumidores para manter a competitividade. Para estes autores, à medida que as organizações se tornam mais centradas no cliente, mais elas investem no desenvolvimento de relacionamentos duradouros com eles como estratégia central de negócio. A importância dos clientes obriga as empresas a aumentarem os esforços para conseguir mais clientes e, sobretudo, mantê-los.

No que se refere à construção do relacionamento entre consumidor e empresa, sabe-se que ele tem início com a venda e é desenvolvido por meio da interação continuada, também denominada de pós-venda (VAVRA, 1993). O autor sugere ainda que não se pense em "completar uma venda" ou "fechar um negócio", mas sim "iniciar um relacionamento" e "construir lealdade", o que demonstra a passagem do marketing transacional para o marketing de relacionamento. O marketing de relacionamento mostra-se diferente do marketing transacional, cujo foco reside na transação e na venda, principalmente por sua orientação a longo prazo e pela concentração no gerenciamento das informações sobre os clientes e das interações com eles (BALLANTYNE; CHRISTOPHER; PAYNE, 2003). Os autores apontam 
que a mudança de foco supracitada é sustentada pela busca de gerenciamento do valor para o cliente, ampliando o posicionamento do marketing tradicional com a perspectiva de convergir com os requisitos dos clientes em longo prazo. Defendem, ainda, que o marketing de relacionamento atua como um condutor de valor nos relacionamentos entre clientes e empresas.

É importante frisar que, nesta transição, o marketing de relacionamento foi entendido apenas como retenção de clientes, banco de dados e até mesmo confundido como programas de fidelidade (D'ANGELO; SCHNEIDER; LARÁN, 2006). Desta forma, foram negligenciados aspectos fundamentais do marketing de relacionamento, como a orientação a longo prazo, o desenvolvimento de vínculos emocionais com consumidores e a confiança entre as partes (BERRY, 1983; O'MALLEY; TYNAN, 2000). O marketing de relacionamento, em sua essência, baseia-se na construção de relacionamentos verdadeiros, o que constitui a real fonte de vantagem competitiva (DAY, 2000), uma vez que é por meio destes relacionamentos que o valor para os clientes é criado (GRÖNROOS, 2009).

Cabe salientar que a adoção da perspectiva relacional em marketing vai além de apenas uma estratégia: o marketing de relacionamento busca envolver e integrar consumidores às atividades de marketing, onde o relacionamento de caráter integrador sugere uma aproximação econômica, emocional e estrutural entre os mesmos (SHETH; PARVATIYAR, 1995). Preconiza-se, assim, uma customização do relacionamento, processo que envolve aprendizagem, gerenciamento e atendimento das preferências individuais dos clientes, de forma que possam criar vantagens na oferta de produtos e serviços, estando de acordo com suas necessidades e fornecendo aos clientes incentivos para que se mantenham leais à organização (BERRY; GRESHAM, 1986).

De acordo com as perspectivas convencionais, o marketing é visto como uma função entre as demais funções organizacionais, sendo considerado mais eficaz e eficientemente planejado e implementado por um departamento separado (GRÖNROOS, 2009). Contudo, o autor defende que, de forma isolada, a função e o departamento de marketing não conseguem apoiar os consumidores nos processos de criação de valor, nem mesmo desenvolver soluções e tomar responsabilidade pelo desenvolvimento de propostas de valor. Na visão de Day (2000), para que os princípios do marketing de relacionamento possam ser colocados em prática, é necessária uma combinação de crenças, valores, conhecimentos, habilidades e diversos recursos, que constituem a cultura da organização. Neste aspecto, Narver e Slater (1990) afirmam que o marketing de relacionamento demanda uma coordenação funcional, que 
consiste na utilização dos recursos de todos os departamentos para criar valor aos consumidores. Woodruff (1997) defende que a firma deve concentrar esforços na combinação de diferentes competências para que o valor desejado pelos clientes seja entregue. Dentro do que propõe Grönroos (2009), o marketing de relacionamento é entendido como uma filosofia que envolve toda a organização, não podendo ser restrito a um departamento ou a uma única função, sendo a entrega de valor ao cliente uma atividade e responsabilidade de toda a esfera organizacional.

Vavra (1993) atenta aos esforços e aos custos de se conquistar novos clientes, sugerindo que a melhor maneira de lucrar se dá por meio do aumento da retenção dos clientes. De fato, à medida que o relacionamento entre consumidor e empresa se desenvolve, os lucros tendem a crescer a cada ano a mais que os clientes permanecem fiéis à empresa (REICHHELD; SASSER JUNIOR, 1990). Neste sentido, a partir do momento em que relacionamentos são desenvolvidos, as organizações passam a conhecer seus clientes, identificando aqueles clientes considerados lucrativos, também denominados clientes estratégicos (MCKENNA, 1999). Neste sentido, Reichheld (1996) indica que os clientes a longo prazo apresentam um comportamento favorável à organização, posto que compram mais, exigem menos tempo e esforços da empresa, são menos sensíveis a preço e tendem a revelar atitudes positivas sobre a organização, trazendo novos clientes. Lovelock, Wirtz e Hemzo (2011) reforçam que reter clientes é importante, contudo, é relevante que se retenham os clientes certos. Dessa forma, Demo e Ponte (2008) argumentam que 20\% dos clientes respondem por $80 \%$ dos lucros das organizações, e estes são os clientes considerados certos ou estratégicos.

Diante da relevância do relacionamento com os clientes e da necessidade de gerenciamento do mesmo, surge, nos anos 1990, um modelo de gestão denominado Customer Relationship Management (CRM), ou gestão do relacionamento com clientes. Para Payne (2006), o CRM prevê o desenvolvimento de relacionamentos com os clientes por meio da união de ferramentas da tecnologia da informação (TI) e das estratégias e pressupostos do marketing de relacionamento. Assim, tem-se que o CRM consiste na integração do marketing e da tecnologia da informação, com o objetivo de fornecer às organizações meios mais eficazes e integrados de atender, reconhecer e cuidar dos clientes (BRETZKE, 2000).

Para Demo (2014), a compreensão quanto aos significados do CRM ainda é limitada. A autora aponta que muitas empresas não concebem o CRM como sinônimo de marketing de relacionamento, mas sim como uma solução tecnológica, fazendo com que a gestão do 
relacionamento com o cliente seja confundida com softwares os sistemas de apoio para implementação do CRM. Ainda que a tecnologia permeie a implantação de um programa de CRM, é fundamental ressaltar que o CRM não é uma tecnologia, mas sim um conjunto de processos e políticas de negócios que integra todas as atividades relacionadas à geração de valor aos clientes, com o propósito de conquistar, manter e servir a estes clientes (GREENBERG, 2001).

A discussão sobre a necessidade de se definir CRM é defendida por Payne (2006), ao afirmar que a busca de uma limpeza conceitual não se limita a um preciosismo semântico. Para o autor, o CRM apresenta-se como uma abordagem estratégica holística, que visa ao gerenciamento do relacionamento com clientes, por meio da criação de oportunidades de utilização de dados e informações para entender os clientes e implementar as estratégias de marketing de relacionamento de forma mais eficiente. Ressalta, ainda, que esta definição tem impacto significativo na compreensão, implantação e utilização do CRM nas organizações. Neste sentido, o autor propõe também que para que o CRM seja bem-sucedido, ele deve compor a visão estratégica da organização, combinando o potencial da tecnologia da informação às estratégias de marketing de relacionamento, o que levará aos relacionamentos lucrativos de longo prazo.

Neste sentido, Zablah, Bellenger, Johnston (2004) afirmam que o termo CRM apresenta diferentes definições, apontando a falta de consenso sobre a forma mais adequada de definição do fenômeno. A revisão de literatura realizada pelos autores identificou cinco perspectivas dominantes frente ao conceito de CRM: (1) CRM como processo, descrito pelas relações desenvolvidas entre compradores e fornecedores a longo prazo, (2) CRM como estratégia, onde as informações advindas dos consumidores determinam os esforços que a empresa investe em determinado relacionamento, (3) CRM como filosofia, em que a retenção de clientes é conquistada por meio do foco na construção e na manutenção do relacionamento, (4) CRM como capacidade, que defende que relacionamentos lucrativos de longo prazo são conquistados apenas quando as firmas adaptam seu comportamento à demanda dos consumidores e (5) CRM como tecnologia, em que tecnologias de gerenciamento de conhecimento e de interações constituem os recursos fundamentais das empresas na construção de relacionamentos lucrativos de longo prazo.

Desta forma, Zablah, Bellenger, Johnston (2004) propõem a seguinte definição para CRM, qual seja, um processo contínuo que envolve o desenvolvimento e a utilização de inteligência de mercado, de forma a permitir que as firmas construam e sustentem ao longo do 
tempo relacionamentos lucrativos com os consumidores. Os autores apontam, ainda, que tal inteligência de mercado é obtida por meio de processos de gestão do conhecimento e, por meio dos resultados destes processos, as organizações poderão selecionar os consumidores certos, priorizar relacionamentos e gerenciar de forma eficiente as interações com os clientes.

Neste sentido, Payne (2006), sugere que o CRM permite às empresas utilizarem informações, conhecer melhor os clientes, oferecer valor por meio de ofertas customizadas e desenvolver relacionamentos de longo prazo. Por conseguinte, o marketing de relacionamento constitui a base filosófica do CRM (BALLANTYNE; CHRISTOPHER; PAYNE, 2003). Neste sentido, Zablah, Bellenger, Johnston (2004) apontam que o marketing de relacionamento, enquanto filosofia norteadora do CRM, enfatiza a importância da retenção dos clientes, fazendo com que o CRM represente a implementação de tal filosofia dentro das organizações.

A definição proposta por Zablah, Bellenger, Johnston (2004), em que CRM pressupõe a criação de inteligência de mercado, converge com a proposta de Campbell (2003), que atribui aos processos internos a capacidade de criar conhecimento sobre os clientes. Posto isto, a autora defende que este conhecimento sobre consumidores é gerado por (1) processo de informação do cliente, que se refere ao conjunto de atividades que buscam identificar as necessidades atuais e potenciais dos clientes, (2) a interação entre marketing e tecnologia da informação, constituída pela comunicação e cooperação entre estas funções, (3) envolvimento da alta administração e (4) sistemas de avaliação e recompensa dos funcionários, uma vez que o comportamento dos mesmos devem estar alinhados com os objetivos da organização quanto à geração do conhecimento sobre os clientes e a integração deste com as estratégias de marketing. Observa-se, assim, que a implementação bem-sucedida do CRM demanda a utilização eficiente das informações sobre os clientes (CAMPBELL, 2003).

Dentro da perspectiva de geração e utilização das informações sobre os clientes, Vavra (1993) destaca sete atividades fundamentais a este processo: (1) preparação e organização das informações dos clientes em um banco de dados, (2) programação de pontos de contatos com os clientes, (3) análise das interações com os clientes e transformação dos dados em informações, (4) elaboração de indicadores de satisfação, (5) desenvolvimento de programas de comunicação com os clientes, (6) patrocínio de eventos ou programações especiais para os clientes, (7) identificação e recuperação de clientes perdidos.

Sob o propósito de investigar a evolução nas pesquisas acadêmicas, foi conduzida uma busca no portal CAPES, visando identificar os resultados empíricos obtidos entre 2010 e julho 
de 2015. Os resultados revelam o vigor da pesquisa acadêmica na área e serão apresentados blocos temáticos, de forma a permitir a compreensão da evolução das pesquisas.

A estratégia desperta forte interesse entre os pesquisadores de marketing de relacionamento e CRM, que exploram o tema através de estudos sobre a importância do gerenciamento das informações sobre os clientes (VICHROSKI; PFITSCHER; GALLON; RICHARTZ, 2010; REIJONEN; LAUKKANEN, 2010). Ademais, Soeini e Jafari (2012) sustentam que a implementação eficiente do CRM como estratégia empresarial está positivamente relacionada com a lucratividade.

De acordo com Huang e Xiong (2010), o CRM mostrou ter atingido uma maturidade estratégica capaz de influenciar todo o ciclo de vida do produto, revelando que o construto orienta as ações das organizações, permitindo que as estratégias estejam alinhadas com as necessidades do mercado. Neste sentido, o marketing de relacionamento é associado à criação de conhecimento, promovendo melhorias organizacionais (KHODAKARAMI; CHAN, 2014).

Os benefícios advindos do marketing de relacionamento como estratégia podem ser traduzidos no desenvolvimento de novos produtos (ERNST; HOYER; KRAFFT; KRIEGER, 2011), na capacidade inovativa das empresas (BATTOR; BATTOR, 2010; LIN; CHEN; CHIU, 2010), no aumento nos níveis de confiança, satisfação e lealdade (ABBADE, 2014). No que tange à lealdade, registra-se a relevância da elaboração e gestão de programas de fidelização de clientes (MENDES; PEDRON, 2014). Ademais, as redes sociais passam a ser incorporadas às estratégias de CRM, como abordagens recentes e inovadoras no contexto do desenvolvimento de relacionamentos com clientes (FRAGA; ROCHA; JANSEN; LOFTI, 2013; TRAINOR; ANDZULIS; RAPP; AGNIHOTRI, 2014; LENDEL; VARMUS, 2015).

Os relacionamentos no mercado corporativo foram abordados por Silva, Pimenta, Lopes e Machado (2012) em estudo sobre redes associativas de varejo; Galão, Baccaro e Chiusoli (2012), em pesquisa em um arranjo de produção local (APL) do setor de tecnologia da informação; e por Brito e Mariotto (2013), ao estudarem o desempenho do relacionamento entre empresas no setor de tecnologia da informação. Salienta-se, ainda, a atenção ao impacto das características da indústria sobre os projetos de CRM (STEEL; DUBELAAR; EWING, 2013).

Os estudos focados em analisar a relação entre marketing de relacionamento e desempenho apontam para a necessidade de uma cultura baseada no valor para o consumidor e no gerenciamento dos (LING-YEE, 2011), onde aspectos relacionados ao marketing interno e à satisfação no trabalho destacam-se como elementos-chave para uma empresa orientada 
para o consumidor (WU; TSAI; FU, 2013). Sob tal perspectiva, surgem estudos que analisam a relação entre marketing de relacionamento e cultura organizacional (MAGALHÃES; CRNKOVIC; MORETTI, 2010; CREMONEZI; PIZZINATTO; GIULIANI; SPERS; OSWALDO, 2013; LOURENÇO, 2014), evidenciando o papel da confiança, envolvimento, trabalho em equipe, inovação, flexibilidade e orientação para resultados, reafirmando a necessidade de uma abordagem holística ao CRM, capaz de integrar os colaboradores da organização à medida que se interage com os clientes (IGLESIAS; SAUQUET; MONTAÑA, 2011). Neste contexto, a literatura assinala a necessidade de uma política de gestão de pessoas em sintonia com os preceitos do marketing de relacionamento (LOURENÇO; SETTE, 2013).

A confiança na organização revela-se bastante presente nas pesquisas em marketing de relacionamento, especialmente no que tange à relação com a lealdade (KAUR; SHARMA; MAHAJAN, 2012; MILAN; DE TONI, 2012; SOARES; BORTOLUZZO; BARROS, 2012), bem como o efeito dos benefícios relacionais na construção da lealdade do consumidor (DA ROCHA; CLARO, 2013; LEE; KIM; PAN, 2014; MOTA, 2014; HUANG, 2015). Neste sentido, a literatura assinala a relevância dos estudos sobre fidelização de clientes ou pósvenda (COMIOTTO; COSTA; SANTOS; MONDO, 2014; AMARAL; CAMARGO; PIZZINATTO; PITOMBO, 2015), engajamento entre empresas e clientes (ASHLEY; NOBLE; DONTHU; LEMON, 2011; HANSLIN; RINDELL, 2014), e qualidade do relacionamento entre cliente e empresa (AA; BLOEMER; HENSELER, 2013), onde os temas supracitados encontram-se associados à construção dos relacionamentos verdadeiros e duradouros. Outros estudos empíricos foram identificados em menor volume, o que sugere lacunas de pesquisa, que é o caso do marketing de relacionamento no terceiro setor (CAMPOS; SILVEIRA; MARCON, 2007).

No que se refere às revisões de literatura sobre o tema, tem-se como referência o artigo de Ngai (2005), que apresentou uma extensa revisão da pesquisa em CRM conduzida entre 1992 e 2002, onde foram identificados 205 artigos, publicados em 85 periódicos acadêmicos de diferentes bases de dados. De acordo com o autor, a pesquisa em CRM pode ser classificada em cinco categorias, a saber, CRM geral, marketing, vendas, serviço e suporte, e tecnologia da informação. Segundo o autor, essas cinco categorias ainda compreendem 34 subcategorias. Como resultado, observou-se também que as áreas mais populares em que os artigos se enquadram foram gerenciamento do CRM, planejamento e estratégia, e CRM geral, seguidos pelos estudos relacionados a software, ferramentas e sistemas, data mining (mineração de dados), gestão do conhecimento e e-commerce. Verificado o vigor da pesquisa 
acadêmica na área, o autor aponta ainda a tendência de crescimento significativo para os próximos anos.

A revisão de literatura conduzida por Das (2009) buscou revelar a situação da pesquisa em marketing de relacionamento publicada entre os anos de 1994 e 2006 . O autor identificou 209 artigos relacionados ao tema marketing de relacionamento, cuja fonte era composta por 56 periódicos pertencentes a bases de dados distintas. $\mathrm{O}$ resultado revelou também que a literatura em marketing de relacionamento pode ser classificada em cinco categorias, a saber, (1) objetivos, abarcando satisfação do cliente, retenção e lealdade; (2) construtos que definem marketing de relacionamento, como confiança, compromisso, cooperação e qualidade do relacionamento, (3) instrumentos, como marketing direto, banco de dados, marketing umpara-um, (4) implicações, tais como privacidade, impacto da cultura, influência da tecnologia e (5) aplicação gerencial, onde se inserem os programas de implementação e as práticas industriais. A maior parte da pesquisa no tema concentrou-se nas categorias objetivos, construtos e instrumentos. Segundo o autor, a pouca pesquisa na categoria aplicação gerencial revela que a literatura em marketing de relacionamento está concentrada na construção da teoria, indicando a necessidade de suporte empírico para as pesquisas na área.

No mesmo ano, Ngai, Xiu e Chau (2009) conduziram a primeira revisão de literatura referente à utilização de data mining, ou mineração de dados, em CRM. A investigação dos autores identificou, no período entre 2000 e 2006, 900 artigos advindos de 24 periódicos, revelando robustez na pesquisa em retenção de clientes, com foco nos temas marketing oneto-one, ou marketing individualizado/personalizado, e programas de fidelização de clientes. Os autores destacaram, ainda, que modelos de classificação e de associação são os mais utilizados para a mineração de dados em CRM. Sob a mesma perspectiva, Pupovac, Zehetner e Sudarevic (2012) identificaram na literatura as abordagens envolvidas na utilização dos dados obtidos por meio de sistemas de CRM, a saber, mensuração do valor do ciclo de vida do consumidor, classificação dos consumidores, taxa de retenção de cientes, conquista de novos consumidores lucrativos e aumento da venda de produtos a clientes já existentes.

Ainda sobre as técnicas de mineração de dados, o estudo de Desai e Kulkarni (2013) revelou a utilização de modelos de associação no setor bancário, apontando-a como uma tarefa tediosa, mas que pode ser beneficiada pela aplicação de algoritmos a priori. Por fim, Sojan, Raphy e Thomas (2014) pesquisaram as técnicas aplicadas aos sistemas de suporte à decisão para o CRM, baseados no volume crescente dos dados de clientes, enfatizando o importante papel da mineração de dados. 
O estudo de Wahlberg, Strandberg, Sundberg e Sandberg (2009) propôs-se a identificar tendências e temas de CRM dentro de quatro categorias específicas, a saber, CRM estratégico, CRM analítico, CRM operacional e CRM colaborativo, no período compreendido entre 1998 e 2006. O resultado da pesquisa revelou que este tema tem mostrado amadurecimento com o passar dos anos, com a predominância dos estudos em CRM analítico e CRM estratégico, sendo esta última a mais popular categoria entre as publicações. Os autores identificaram ainda duas subcategorias de publicações dentro de CRM estratégico, envolvendo a implementação do CRM e, a segunda, tratando de vantagem competitiva.

Na mesma linha, Kevork e Vrechopoulos (2009), conduziram uma revisão de literatura no período de 2000 a 2006, identificando 396 estudos publicados sobre CRM. As pesquisas encontradas foram classificadas em nove categorias: CRM geral, e-commerce, marketing de relacionamento, sistemas de informação, gestão do conhecimento, software, gerenciamento da qualidade total, atributos de CRM relacionados às intenções dos consumidores e CRM nos ambientes culturais. Já a revisão de literatura realizada por Gupta e Sahu (2012) identificou cinco amplas categorias de pesquisa, a saber, conceitos, aplicações gerenciais, desenvolvimento de mercado, aspectos tecnológicos e desempenho empresarial. Os autores apontaram ainda que as categorias conceitos sobre marketing de relacionamento e desenvolvimento de mercado foram as mais populares entre os artigos identificados.

Com o objetivo de sintetizar os estudos que investigaram temas de pesquisa dentro do CRM, Mandi (2010) conduziu uma meta-análise de artigos científicos relacionados a CRM com o objetivo de identificar as principais abordagens que compõem o tema, abarcando pesquisas de diferentes países e diferentes indústrias. Os resultados revelaram que os estudos em CRM podem ser divididos entre as abordagens estratégica e tecnológica, uma vez que são as linhas de pesquisa mais frequentes, onde diferentes condições e organizações apresentarão resultados distintos. A revisão conclui que apesar de o CRM ser uma das áreas do marketing que mais crescem, as dificuldades e os fatores influenciadores de sua implementação requerem atenção especial dos pesquisadores.

No que se refere à área de pesquisa relativa à adoção da tecnologia de CRM, Awasthi e Sangle (2012) sintetizaram o estado da arte nesta linha, revelando quatro temas principais: CRM, com enfoque no alinhamento estratégico; CRM multicanal, cujo foco reside na implementação de CRM e suas implicações; e-CRM, voltado para a implementação de canais de relacionamento on-line e o impacto dessa ferramenta e, por fim, m-CRM, onde o foco recai nos artigos que relacionam marketing e tecnologia da informação. 
Mohammadhossein e Zakaria (2012), por meio de uma revisão de estudos publicados entre 2005 e 2012, identificaram uma série de benefícios que o CRM traz para os consumidores, a saber, melhoria dos serviços prestados aos clientes, aumento dos serviços personalizados, atenção às necessidades dos clientes, segmentação de consumidores, melhora no marketing customizado, integração de canais, ganho de tempo e melhorias no conhecimento sobre o consumidor.

Recentemente, Khalafinezhad e Long (2013) conduziram uma revisão de literatura com o objetivo de identificar os elementos de CRM que se relacionam aos construtos satisfação e lealdade de clientes. Os resultados revelaram quatro importantes aspectos a serem considerados, a saber, comportamento de colaboradores, qualidade do serviço prestado, desenvolvimento de relacionamento com clientes e gerenciamento da interação com clientes. No mesmo ano, Benouakrim e El Kandoussi (2013) propuseram uma análise teórica sobre os principais conceitos de marketing de relacionamento e seus principais componentes. Os autores identificaram, na literatura, que os principais elementos críticos de CRM consistem em desempenho da força de vendas, lealdade, comunicação boca-a-boca, comunicação e cooperação organizacional, e o contexto em que a empresa se insere. Por outro lado, os autores identificaram que tais elementos influenciam aspectos como comprometimento, confiança, satisfação e qualidade do relacionamento.

Quanto às revisões de literatura realizadas em âmbito nacional, Almeida, Lopes e Pereira (2006) foram os primeiros a analisar a produção cientifica brasileira sobre marketing de relacionamento, revelando que entre os anos de 1990 e 2004, foram publicados 33 artigos dentro da temática, nos principais periódicos brasileiros de administração. Os autores apontam a evolução desta linha de pesquisa no país, bem como os principais autores, bases de investigação e métodos utilizados.

Brambilla (2010), em análise bibliográfica, levantou 34 artigos publicados sobre o tema até o ano de 2009, identificando as lacunas existentes na literatura, sugerindo agenda de pesquisa para os temas: implantação de CRM, percepção de funcionários em relação ao CRM, práticas e treinamentos que conduzem ao CRM efetivo, aspectos financeiros e diferenças entre CRM em empresas de produto e empresas de serviço.

$\mathrm{O}$ amadurecimento desta área de pesquisa foi confirmado no ano seguinte com o estudo realizado por Demo, Rozzett, Ponte, Ferreira e Mendes (2011), onde 65 artigos publicados em periódicos e anais nacionais de primeira linha (QUALIS $\geq$ B2) foram identificados no período entre 2000 e 2010. Entre os principais resultados, tem-se a 
identificação do parco esforço na construção e validação de medidas para avaliar a percepção de clientes corporativos e consumidores, fazendo-se necessário, conforme os autores. Apontase, ainda, a relevância estratégica para as organizações dos estudos sobre CRM em tempos de competitividade recrudescente, o que foi demonstrado por um patente aumento no interesse de pesquisadores sobre o tema, considerando a criação de grupos de pesquisa sobre CRM no Brasil e os indicadores de produção Científica, Técnica e de Assessoria (CTA) da Base de Dados Lattes do CNPq (Conselho Nacional de Desenvolvimento Científico e Tecnológico).

Faria, Giuliani, Pizzinato e Spers (2014) analisaram a produção acadêmica em marketing durante vinte anos, com base no levantamento de Almeida, Lopes e Pereira (2006) e na análise dos anais do EnANPAD entre 2005 a 2012. No total, os autores revelaram que a produção nacional em CRM compreende 96 artigos, com destaque para a predominância de pesquisas $\mathrm{B} 2 \mathrm{C}$, business-to-consumer ou voltadas ao consumidor final.

Por fim, o trabalho publicado por Demo, Fogaça, Ponte, Fernandes e Cardoso (2015), a partir da análise da produção nacional no período entre 2000 e 2013 somente em periódicos de primeira linha (QUALIS $\geq \mathrm{B} 1$ ), revelou a existência de 52 artigos, com destaque para as revistas ReAd, RAC e Faces, indicando, ainda, a predominância de trabalhos teóricoempíricos, especialmente voltados para o mercado consumidor. Assim, o recente levantamento reforça o interesse dos pesquisadores no tema, bem como a relevância estratégica para as organizações do estudo da temática.

No que se refere às medidas de CRM, foram identificados estudos de validação de escala, baseados principalmente nos trabalhos de Wilson e Vlosky (1997), Sin, Tse e Yim (2005), Agariya e Singh (2012a) e Rozzett e Demo (2010a; 2010b; 2011).

Wilson e Vlosky (1997) conduziram o desenvolvimento e validação de uma escala de CRM para o mercado corporativo, considerada um instrumento consistente e preciso na verificação do grau de relacionamento entre empresas. No Brasil, esta escala foi adaptada para o setor industrial por Viana, Cunha Jr. e Slongo (2005). No mesmo ano, Sin, Tse e Yim (2005) validaram uma escala com o objetivo de mensurar as dimensões de CRM praticadas por empresas prestadoras de serviços financeiros de Hong Kong. A escala de Sin, Tse e Yim (2005) foi validada na Jordânia por Akroush, Dahiyat, Gharaibeh e Abu-Lail (2011) com o objetivo de examinar a capacidade de generalização da escala original, obtendo-se resultados satisfatórios e revelando, ainda, uma relação positiva entre a implementação do CRM com desempenho empresaria, especialmente no desempenho financeiro e desempenho de marketing. 
Mais tarde, uma escala de CRM foi desenvolvida e aplicada às indústrias manufatureiras na Índia por Soch e Sandhu (2008), no mesmo ano que Wang e Feng (2008) validaram uma escala de CRM para o setor de serviços na China. Tem-se ainda o trabalho de Öztaysi, Sezgin e Özok (2011), que propuseram um instrumento para avaliar os processos internos de CRM na Turquia.

Recentemente, os estudos conduzidos por Agariya e Singh (2012a; 2012b; 2013) tiveram como resultado um índice de CRM para os setores bancários e de seguros, além do desenvolvimento de uma escala de CRM para clientes de hospitais públicos indianos. Foi identificada também a pesquisa de Zulkifli e Tahir (2012), que validaram uma escala de práticas de CRM com seis dimensões especificas para os clientes do setor bancário.

Por fim, as medidas em CRM passam a ser objeto de interesse de pesquisadores brasileiros, com destaque para os estudos pioneiros de Rozzett e Demo (2010a, 2010b), que desenvolveram a Escala de Relacionamento com Clientes (ERC), cujo objetivo consiste em avaliar a percepção de clientes quanto ao relacionamento com empresas em geral. A escala foi validada no Brasil especificamente para o mercado consumidor (B2C, do inglês Business-toConsumer). Com base nas escalas de Rozzett e Demo (2010a, 2010b), outras escalas foram adaptadas para segmentos específicos, quais sejam, a ERC para Disney e parques de diversões (VASCONCELOS; DEMO, 2012); a ERC para Nintendo Wii e vídeos-games (BATELLI; DEMO, 2012); a ERC para bebidas, cerveja SKOL e guaraná Antártica (LOPES; DEMO, 2012) e a ERC para clientes de telecomunicações (CARDOSO, 2014).

Semprebom, Maffezzolli, Ribeiro e Prado (2014) contribuíram com a literatura em relacionamento com marcas por meio de uma escala para mensuração da interdependência com a marca. Conforme os autores, a escala validada permite avaliar o nível de dependência que os clientes apresentam em relação a marcas, funcionando como um preditor da lealdade e da construção de desenvolvimentos em longo prazo, baseados nas práticas de consumo.

Há pouco, uma escala de relacionamento de CRM foi publicada na administração pública, a Escala de Relacionamento com o Cidadão (DEMO; PESSÔA, 2015), tendo alcançado o objetivo de fornecer um instrumento a ser utilizado na gestão eficiente do relacionamento com cidadãos, ou CiRM.

Recentemente, Demo e Rozzett (2013) validaram a ERC também nos Estados Unidos. O resultado foi um modelo unifatorial com alta confiabilidade e ajuste melhor que as versões brasileiras. As autoras assinalam, assim, a relevância da comparação entre as versões validadas no Brasil e a versão americana, de forma que se possa analisar a confiabilidade, 
número de itens e validade. Verifica-se, de acordo com a Tabela 3, que os parâmetros supracitados são similares, permitindo observar que a estrutura da escala se mantém estável, mesmo validada em um outro contexto. 
Tabela 3 - Comparação entre as ERC brasileira e ERC americana

\begin{tabular}{c|c|c|c}
\hline Escala/Parâmetro & $\begin{array}{c}\text { ERC Brasil - versão } \\
\text { completa }\end{array}$ & $\begin{array}{c}\text { ERC Brasil - versão } \\
\text { reduzida }\end{array}$ & ERC Estados Unidos \\
\hline Confiabilidade & $\alpha=0,93$ & $\alpha=0,92$ & $\alpha=0,92$ \\
\hline Número de Itens & 20 & 8 & 14 \\
\hline Qualidade dos Itens & $\begin{array}{c}70 \% \text { classificados } \\
\text { como excelente, muito } \\
\text { bom e bom }\end{array}$ & $\begin{array}{c}\text { como excelente, muito } \\
\text { bom e bom }\end{array}$ & $\begin{array}{c}\text { como excelente, muito } \\
\text { bom e bom }\end{array}$ \\
\hline $\begin{array}{c}\text { Variância Explicada } \\
\text { Total }\end{array}$ & $40 \%$ & $64 \%$ & $50 \%$ \\
\hline
\end{tabular}

Fonte: adaptada de Rozett e Demo (2013) (tradução da autora)

A ERC validada por Demo e Rozzett (2013), com índices psicométricos bastante confiáveis, consistirá no instrumento utilizado para mensurar a percepção de relacionamento dos clientes neste estudo.

\subsubsection{Marketing de Relacionamento (CRM): Revisão da Produção Nacional}

Tal qual na seção 2.1.2, esta seção abordará uma síntese da revisão bibliométrica da produção nacional realizada no período compreendido entre 2010 e 2015, de forma a ilustrar o panorama da pesquisa em CRM no Brasil. Os mesmos critérios foram adotados quanto à seleção dos periódicos, excetuando-se os da psicologia, uma vez que CRM é um tema estudado prioritariamente em administração/marketing.

Foi realizada busca para identificar nos títulos, resumos ou palavras-chave, os seguintes termos: CRM, customer relationship management, gestão do relacionamento com cliente, relacionamento com cliente, marketing de relacionamento e relationship marketing. A primeira parte deste levantamento resultou em 46 artigos, que foram analisados sistematicamente (leitura dos resumos e dos artigos na íntegra) conforme recomendam Dybå e Dingsøyr (2008) com o objetivo de confirmar se eram artigos que efetivamente tratavam de CRM ou apenas o citavam. Após esta triagem, a revisão da produção nacional aqui apresentada compreendeu 22 artigos que satisfizeram os critérios estabelecidos. As categorias de análise foram as mesmas da seção 2.1.2.

No que se refere aos periódicos, a Brazilian Business Review (BBR) lidera o número de publicações sobre CRM, com quatro artigos publicados no período, o que representa $18 \%$ da amostra analisada. A segunda colocação é compartilhada pela Revista Brasileira de Gestão 
de Negócios e pela Revista Eletrônica de Administração (REAd), ambas com três publicações no período, representando $14 \%$ do volume total. Na sequência, também empatadas com dois artigos ou 9\% do total, encontram-se a Revista de Administração de Empresas (RAE) e a Revista de Administração da Universidade Federal de Santa Maria (UFSM). Com um artigo cada, o que equivale a 5\%, estão a Revista de Ciências da Administração, a Revista FACES, a Revista de Administração Pública, a Revista de Administração e Inovação, a Revista de Administração da Unimep, a Revista de Gestão da Tecnologia e Sistemas de Informação e a Revista Portuguesa e Brasileira de Gestão. Por fim, os demais periódicos não apresentaram publicações sobre CRM no período estipulado. Os dados apresentados encontram-se ilustrados no Gráfico 1.

Gráfico 1 - Artigos sobre CRM publicados nos periódicos selecionados

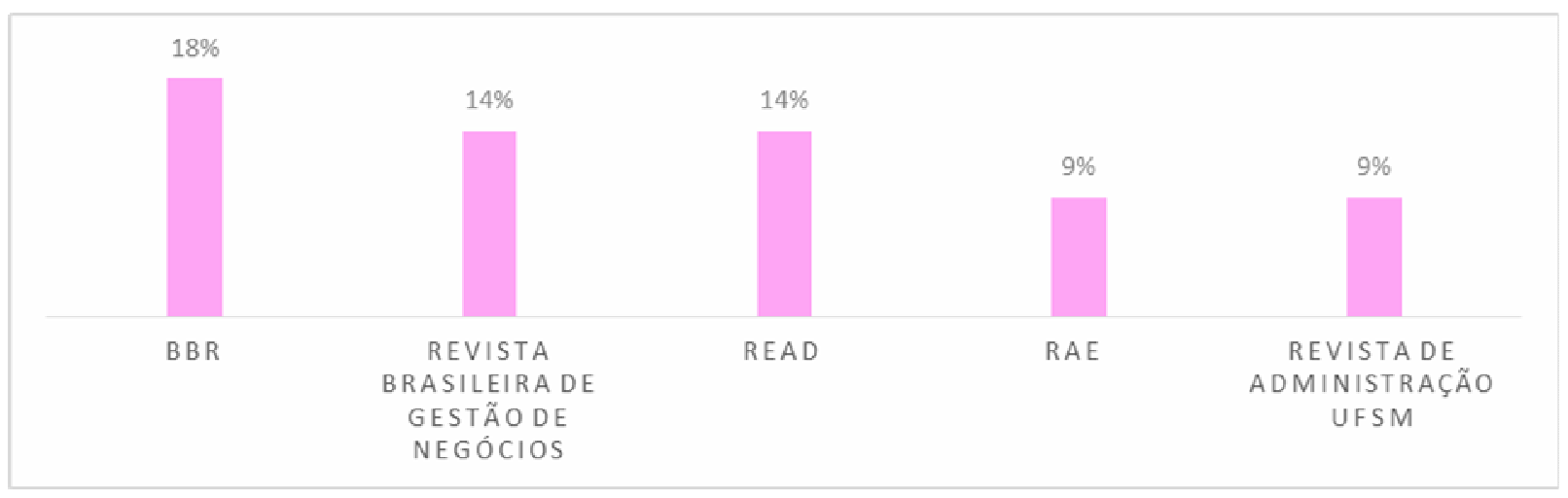

Fonte: Elaborado pela autora

Quanto à produção por ano, conforme o Gráfico 2, observa-se que os primeiros quatro anos analisados revelam uma crescente ascenção em relação ao volume produzido na área, seguida de uma queda em ano de 2014, ano em que apenas um artigo foi publicado, nos periódicos pesquisados, cabe-se ressaltar. Não obstante, no ano de 2015 foram identificadas seis publicações sobre CRM, colocando-se como o ano mais produtivo do período analisado, desvelando um aumento do interesse dos pesquisadores pelo tema. 
Gráfico 2 - Artigos sobre CRM publicados entre 2010 e 2015

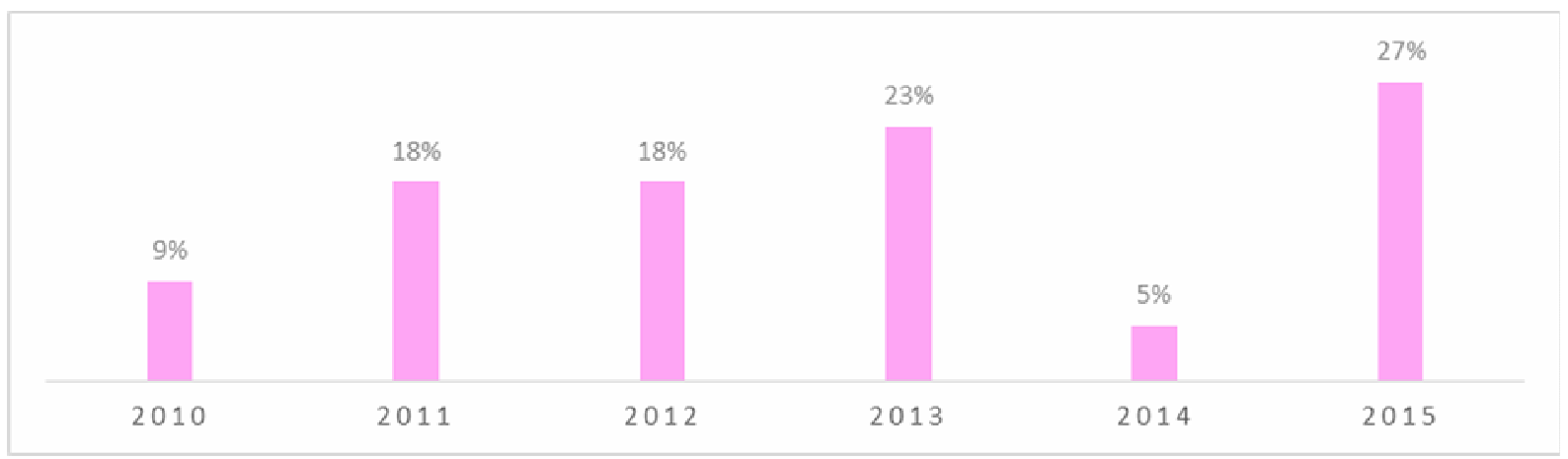

Fonte: Elaborado pela autora

No que tange ao enquadramento dos estudos, observa-se a predominância de trabalhos teórico-empíricos, representando $82 \%$ do volume analisado, enquanto apenas $18 \%$ dos artigos caracterizaram-se como ensaios teóricos. O Gráfico 3 apresenta a proporção encontrada quanto ao enquadramento dos estudos.

Gráfico 3 - Enquadramento dos artigos sobre CRM

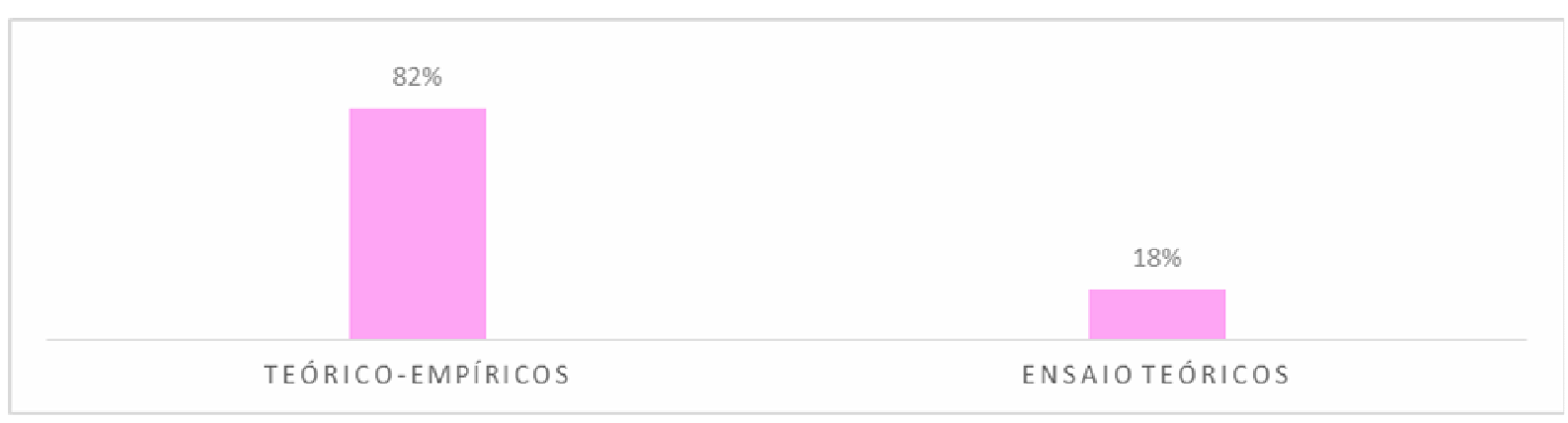

Fonte: Elaborado pela autora

Quanto às instituições de origem dos autores dos estudos, duas instituições se destacaram, a saber, a Universidade Federal do Paraná (UFPR) e a Universidade de Brasília (UnB), com quatro artigos ou $11 \%$ do volume total cada uma. Na sequência, com três artigos publicados no período cada uma, representando $8 \%$ do total, encontram-se a Fundação Getúlio Vargas (FGV/SP), a Universidade Metodista de Piracicaba (UNIMEP) e a Universidade Nove de Julho (UNINOVE). Já com dois artigos publicados cada, representativos de 6\% da amostra total, tem-se a Faculdade Adventista da Bahia (FADBA), a Universidade do Vale do Rio dos Sinos (UNISINOS) e a Universidade de São Paulo (USP). O 
Gráfico 4 representa graficamente os dados supracitados. Para efeitos de visualização, estão representadas a seguir apenas as instituições cujas publicações superam $5 \%$.

Gráfico 4 - Instituição de origem dos autores que publicaram sobre CRM

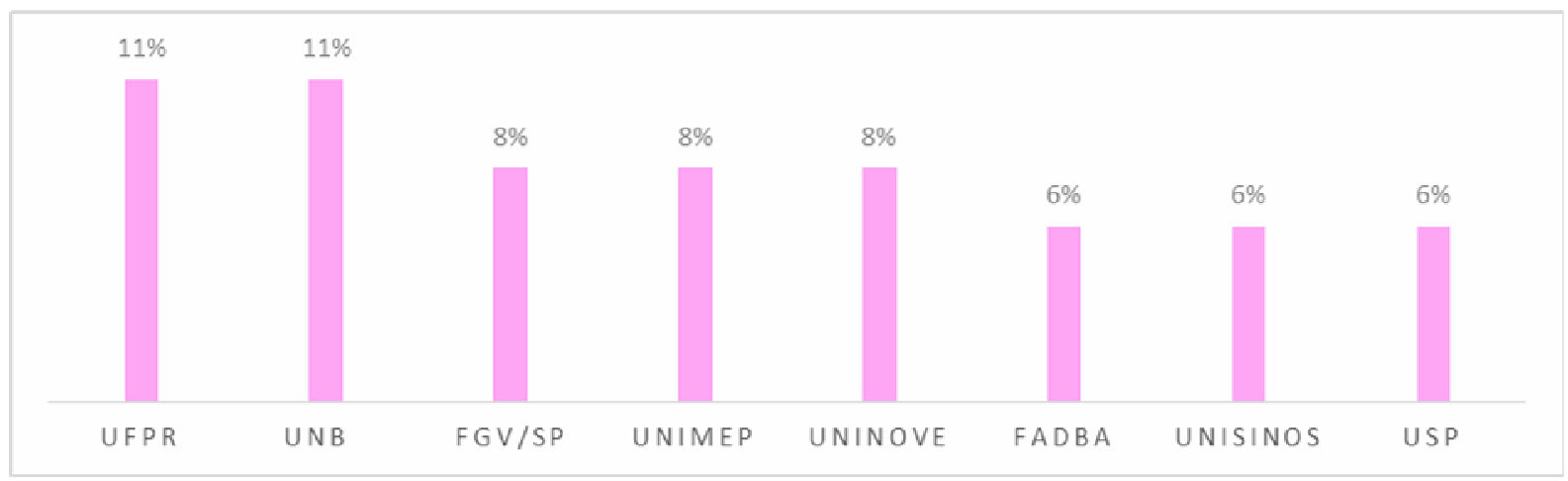

Fonte: Elaborado pela autora

Entre os trabalhos identificados, alguns autores tiveram destaque ao publicar mais de um artigo dentro do período analisado. Posto isto, a Tabela 4 apresenta o nome destes autores, seguido por sua instituição de origem e o número de artigos publicados entre 2010 e 2015.

Tabela 4 - Autores que mais publicaram entre 2010 e 2015

\begin{tabular}{l|l|c}
\hline \multicolumn{1}{c|}{ AUTOR } & \multicolumn{1}{c}{ INSTITUIÇÃO DE ORIGEM } & $\begin{array}{c}\mathbf{N}^{\mathbf{0}} \text { DE } \\
\text { ARTIGOS }\end{array}$ \\
\hline Gisela Demo & UnB & 3 \\
\hline Cristiane Drebes Pedron & Instituto Superior de Economia e Gestão & 3 \\
\hline Paulo Henrique Muler Prado & PUC/RS & 3 \\
\hline Antônio Carlos Giuliani & UNIMEP & 2 \\
\hline Eliane Cristine Francisco Maffezzolli & UFPR & 2 \\
\hline Fabio Vinicius de Macedo Bergamo & UNIMEP & 2 \\
\hline Lesley Carina do Lago Attadia Galli & USP & 2 \\
\hline Licione Marques Torres & Faculdade Monteiro Lobato & 2 \\
\hline Silvia Helena Carvalho Ramos Valladão de \\
Camargo & USP & 2 \\
\hline
\end{tabular}

Fonte: Elaborada pela autora

No que se refere à classificação dos assuntos abordados dentro do tema CRM, utilizou-se a classificação proposta por Demo et al. (2011). Houve predominância de artigos na categoria "CRM B2C" (business-to-consumer ou mercado consumidor), com oito artigos publicados, representando $36 \%$ do total analisado. Na sequência, encontram-se as categorias "CRM, conceitos e fundamentos" e "Variáveis Correlatas" - artigos que tratam das variáveis 
qualidade, lealdade, satisfação e serviço de atendimento ao cliente no contexto do CRM com quatro artigos cada, representativos de $18 \%$ do total. A categoria "Desenvolvimento e Validação de Medidas", com três artigos, representa 14\% da amostra. Tem-se, ainda, as categorias "CRM B2B" (business-to-business ou mercado corporativo), "Estudos Relacionais", que compreende pesquisas de antecedentes e consequentes do CRM, e, por fim, “Tecnologia e Serviços da Informação", cada uma com um artigo publicado, ou 5\% do total. Tais informações encontram-se ilustradas pelo Gráfico 5.

Gráfico 5 - Assuntos mais estudados em CRM

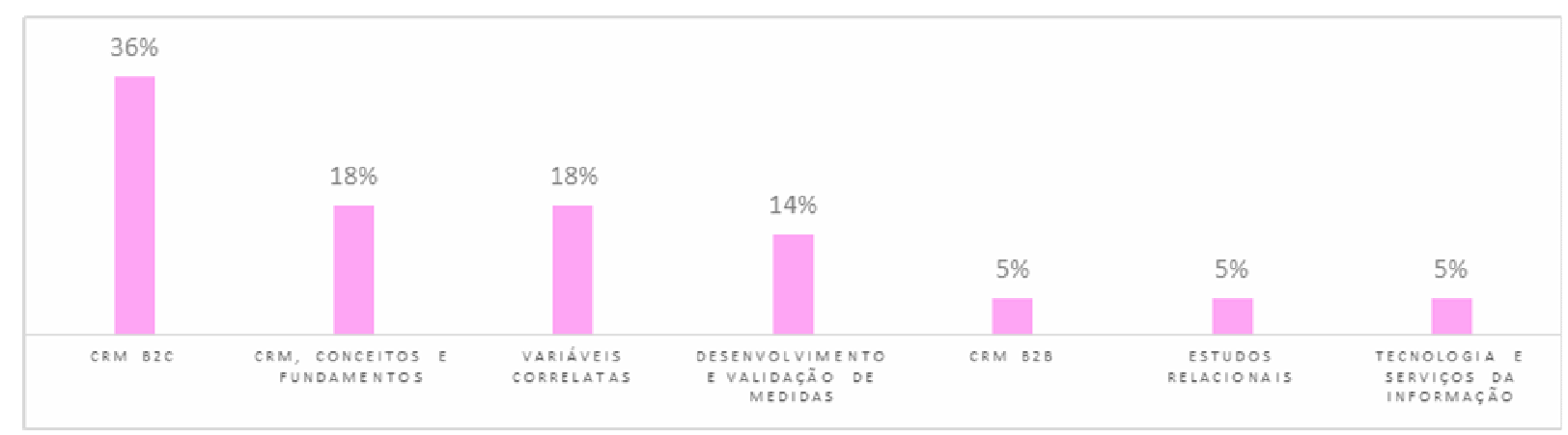

Fonte: Elaborado pela autora

No que se refere aos trabalhos de enquadramento teórico-empírico, observa-se a prevalência de artigos de abordagem quantitativa, visto que compuseram 58\% do volume total analisado. Na sequência, encontram-se os estudos de natureza qualitativa, representando $26 \%$ do total. Por fim, tem-se os estudos de abordagem multimétodo, ou seja, mesclaram métodos qualitativos e quantitativos (quali-quanti), representativos de 16\% dos artigos teóricoempíricos. O Gráfico 6 demonstra estes resultados.

Gráfico 6 - Natureza dos artigos teórico-empíricos sobre CRM

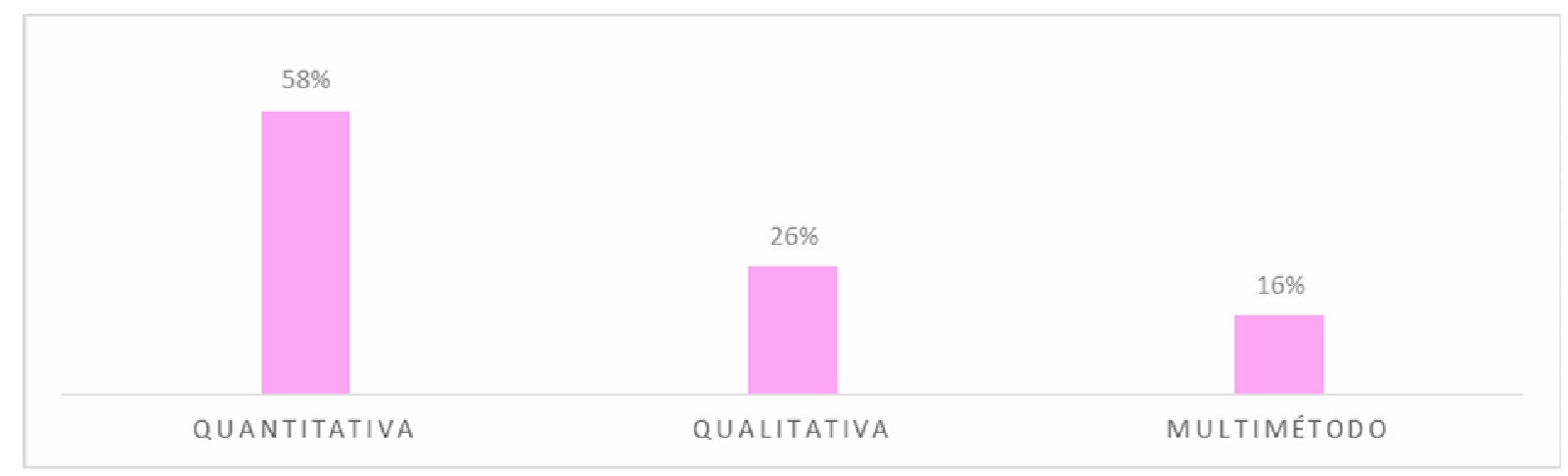

Fonte: Elaborado pela autora 
Dentro dos 18 artigos identificados como teórico-empíricos, 17 destes consistem em trabalhos realizados em empresas privadas, ou seja, no $2^{\circ}$ setor da economia. Apenas um artigo teve como lócus de pesquisa o $1^{\circ}$ setor da economia. Os dados revelaram ainda que as empresas participantes dos estudos teórico-empíricos são pertencentes aos mais diversos ramos de atuação. O maior foco dos pesquisadores esteve no ramo de telecomunicações, com $24 \%$ do total. Em seguida, o ramo de tecnologia da informação com $12 \%$ e, empatados com $8 \%$ cada, os ramos editorial e de higiene e beleza. Devido à alta pulverização dos resultados obtidos, o Gráfico 7 ilustra apenas os ramos de atuação que estiveram presentes em mais de um artigo dentro da amostra.

Gráfico 7 - Ramo de atuação das empresas pesquisadas

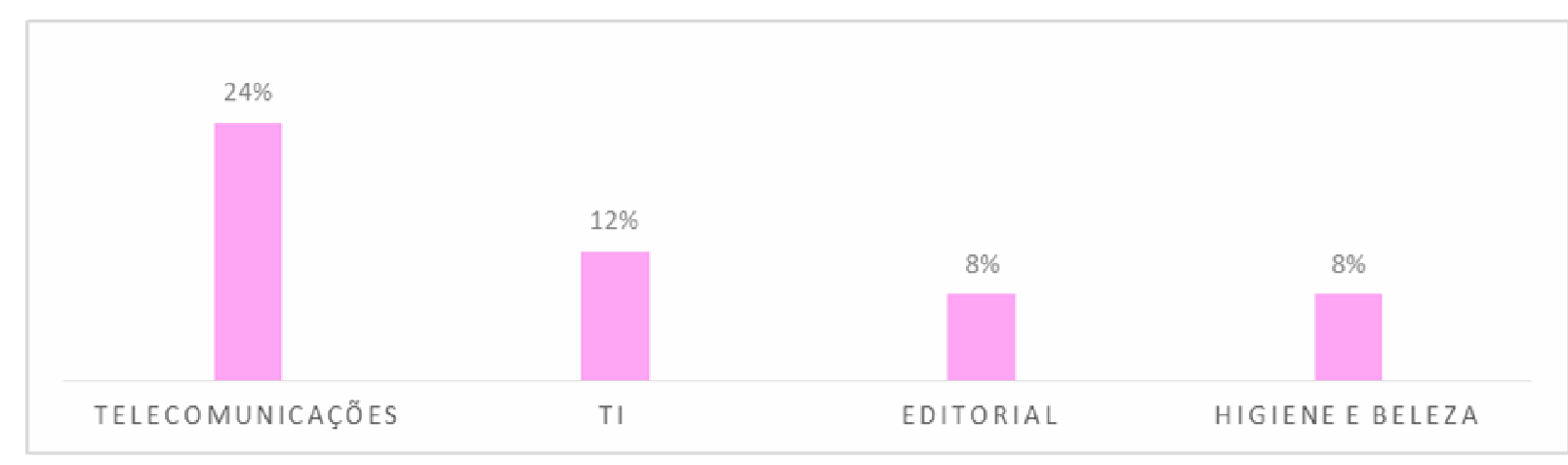

Fonte: Elaborado pela autora

No que se refere aos instrumentos de coleta de dados, o questionário foi o instrumento de coleta de dados mais utilizado entre os artigos analisados, representando $60 \%$ da amostra, o que condiz com a maioria das pesquisas possuírem natureza quantitativa. Na sequência, observa-se a entrevista em segundo lugar, abarcando $30 \%$ da amostra. Os dois instrumentos destacam-se entre os resultados, que abarcam, ainda, o grupo focal, painel com especialistas e estudo de caso que, somados, contemplam $10 \%$ do volume total. Estes dados encontram-se no Gráfico 8. 
Gráfico 8 - Instrumentos de coleta de dados utilizados

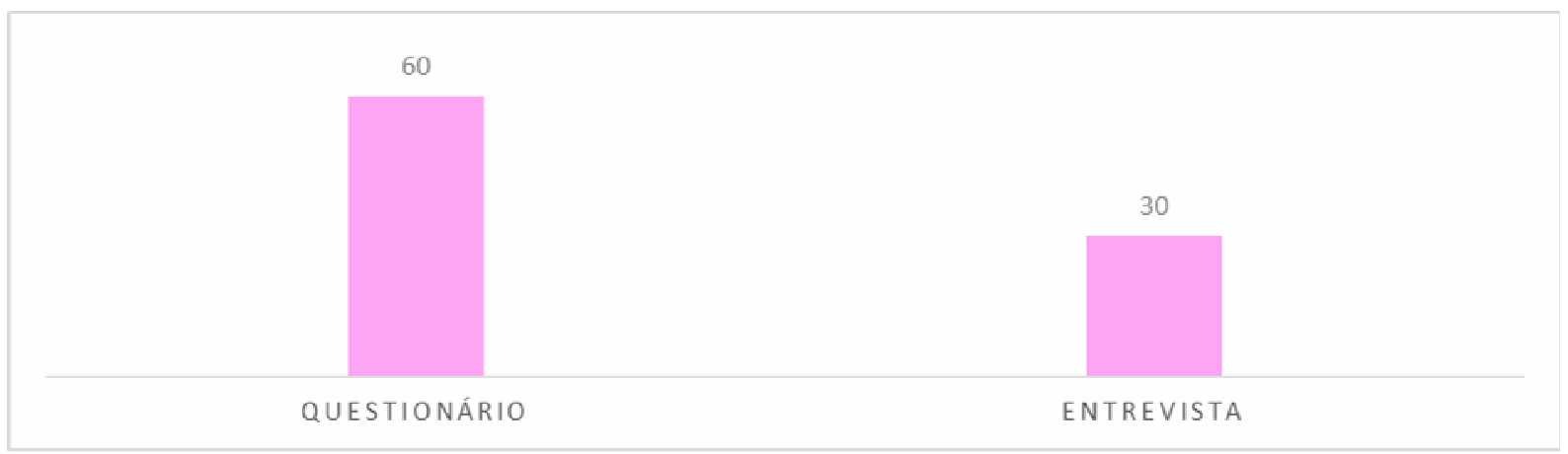

Fonte: Elaborado pela autora

Os artigos encontrados utilizaram-se de diversas técnicas de análise de dados para a compilação de seus resultados. Muitos artigos, inclusive, fizeram uso de mais de uma técnica, combinando técnicas de análise qualitativa e quantitativa. A análise de conteúdo foi a técnica mais utilizada no período, presente em $27 \%$ dos artigos. Este resultado pode ser atribuído à publicação de estudos multimétodo, que combina os dois tipos de abordagem. Na sequência, a segunda posição é dividida pela análise de regressão múltipla e pela modelagem por equações estruturais, cada uma utilizada em $15 \%$ dos estudos. Seguindo, tem-se a triangulação sequencial, encontrada em $12 \%$ dos estudos. A análise fatorial exploratória, por sua vez, foi identificada em 9\% das pesquisas. Por fim, análise correlacional, análise de agrupamento, análise de frequência simples, análise de variância e escalonamento multidimensional também se fizeram presentes nos estudos, pouco representativos, o que justifica sua exclusão do Gráfico 9.

Gráfico 9 - Técnicas de análise de dados utilizadas

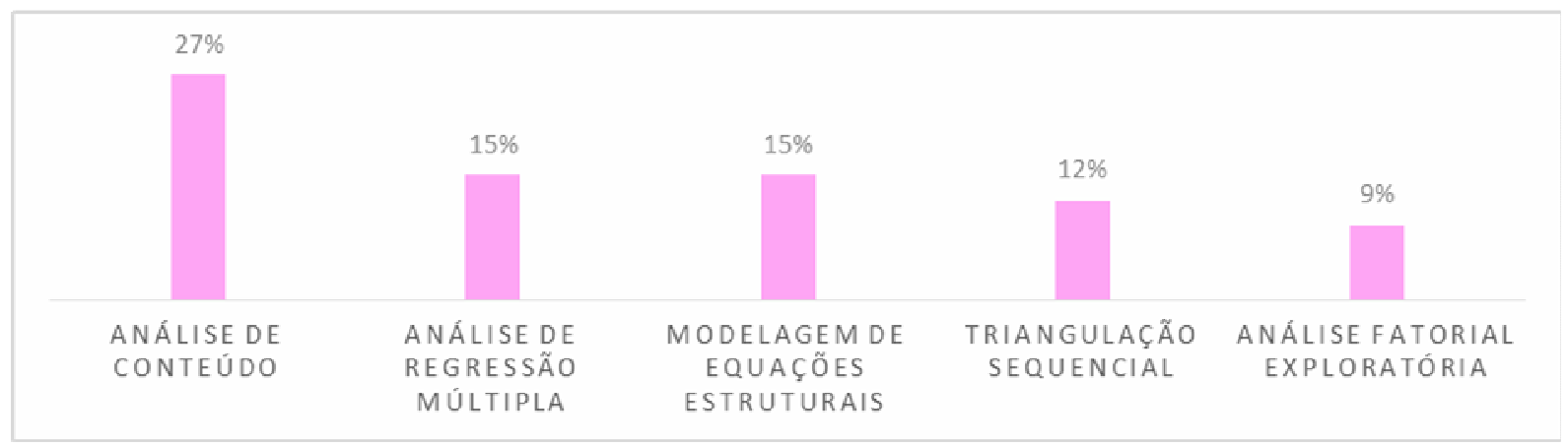

Fonte: Elaborado pela autora 
De acordo com as informações encontradas a respeito da produção nacional sobre CRM, é possível traçar algumas considerações quanto à evolução do tema dentro da literatura científica brasileira.

No que tange ao número de artigos publicados, o ano de 2010 iniciou tímido em publicações, observando-se a retomada do crescimento em 2011, que se mantém em 2012 e apresenta um pico em 2013. O ano de 2014 apresenta um declínio, lembrando, contudo, que o recorte da análise foi feito em periódicos Qualis B1. O ano de 2015, contudo, representa novo vigor da pesquisa na temática, período em que foi identificado pico de produtividade. A análise dos artigos publicados revela a necessidade de compreender o CRM como filosofia e estratégia, indicando a sua relevância estratégica para a atividade econômica das empresas pesquisadas.

No que se refere aos temas estudados dentro do CRM, observa-se a predominância de estudos na categoria “CRM B2C" em detrimento das outras, o que retrata um contraponto à maioria das pesquisas em CRM no exterior serem realizados no âmbito do mercado corporativo, B2B (Faria et al., 2014). Ademais, sugere-se o avanço de pesquisas na categoria "CRM, conceitos e fundamentos", para que o tema possa ser finalmente entendido em sua essência e melhor definido (PAYNE, 2006; GRÖNROOS, 2009), sem que o confundam com uma solução tecnológica, e para que possa, assim, cumprir seus verdadeiros objetivos.

No que se refere a "Desenvolvimento e Validação de Medidas", os esforços na criação de instrumentos capazes de mensurar os efeitos do CRM nas organizações serão bem-vindos, visto que os resultados nesta área viabilizarão diagnósticos organizacionais em CRM. No Brasil, o único instrumento encontrado para avaliar o mercado consumidor (B2C) é a Escala de Relacionamento com Clientes (ROZETT; DEMO, 2010), revelando uma importante lacuna na literatura. Foi identificada ainda, o desenvolvimento e validação de uma escala voltada para o relacionamento com o cidadão (DEMO; PESSÔA, 2015), ampliando o domínio do estudo na área, representando uma inovação tanto para a literatura de marketing de relacionamento quanto para os estudos em empresas públicas, ao abordarem o CRM no setor público, ou CiRM (Citizen Relationship Management).

Neste aspecto, uma outra lacuna a ser preenchida consiste na necessidade de pesquisas realizadas em organizações públicas e em organizações não-governamentais, visto que os estudos analisados contemplaram, em sua maioria, empresas pertencentes ao $2^{\circ}$ setor da economia, com a identificação de apenas uma publicação voltada às organizações públicas. A ênfase em estudos nos demais setores justifica-se pela necessidade de gerenciamento do 
relacionamento entre empresas públicas e os cidadãos, por meio do CiRM, o que contribuirá para o desenvolvimento de políticas públicas capazes de melhorar o atendimento e os serviços prestados aos cidadãos. No que se refere ao terceiro setor, é patente a necessidade de análise do relacionamento entre tais organizações e os públicos por ela atendidos, onde possivelmente especificidades do setor serão desveladas.

No que se refere aos trabalhos teórico-empíricos, os estudos de natureza quantitativa tiveram destaque, confirmando a predominância desta abordagem dentro do tema CRM, o que foi também anteriormente apontado por Almeida, Lopes e Pereira (2006) e Pinto e Lara (2010). Ainda que tal abordagem seja fonte de informações valiosas à academia e às organizações, defende-se a realização de ensaios teóricos e revisões de literatura, com o objetivo de refinar os conceitos acerca do tema e consolidar a área de pesquisa. Além disso, sugere-se fortemente a adoção da abordagem multi-método, abarcando a objetividade e mensuração obtidas por meio dos métodos quantitativos, mas preservando a profundidade e interpretação conquistadas por meio nas análises qualitativas.

Por fim, é contributivo realizar uma comparação entre os dados apresentados e os dados de bibliometrias anteriores. A revisão de Almeida, Lopes e Pereira (2006) contemplou os anos de 1990 a 2004, resultado em 33 publicações. Posteriormente, Brambilla (2010) realizou uma análise bibliográfica que identificou 34 artigos publicados sobre o tema até o ano de 2009. Demo et al. (2011), visando traçar um panorama da primeira década do milênio, ou seja, período entre 2000 e 2010, encontraram 65 artigos. Faria et al. (2014) analisaram a produção acadêmica no tema dos últimos vinte anos, com base no levantamento de Almeida, Lopes e Pereira (2006) e na análise das pesquisas na área entre 2005 a 2012, revelando que, no total, a produção nacional em CRM compreende 96 artigos. Por fim, Demo et al. (2015) identificaram 52 artigos no período compreendido entre 2000 e 2013. No entanto, cabe destacar que as revisões de Faria et al. (2014) e Almeida, Lopes e Pereira (2006) contemplaram apenas os anais de Enanpad e os periódicos RAE e RAUSP, o que certamente inflacionou a quantidade de artigos encontrados.

Tem-se, assim, como resultados da revisão da produção nacional proposta, que o tema é relevante e tem despertado o interesse dos pesquisadores brasileiros nos últimos anos.

\subsubsection{Institucionalização da Pesquisa em CRM}

Esta seção abordará a institucionalização da pesquisa em CRM ou Marketing de Relacionamento no Brasil, visando à construção de um panorama da pesquisa, obtido a partir 
dos grupos de pesquisa identificados sob a denominação "CRM", "marketing de relacionamento" e "gestão do relacionamento com cliente".

O Diretório de Grupo de Pesquisa - Base Corrente - da Plataforma Lattes revelou a existência de 22 grupos de pesquisa para a busca "marketing de relacionamento", todos pertencentes à área de estudo das ciências sociais aplicadas.

A busca por "gestão do relacionamento com cliente" acusou dois grupos de pesquisa, revelando um grupo em comum com a busca "marketing de relacionamento" e um grupo em comum com a busca "CRM". No que tange a área predominante, os grupos pertencem às ciências sociais aplicadas e às engenharias.

Por fim, a busca por "CRM" revelou oito grupos de pesquisa, com dois grupos em comum com "marketing de relacionamento" e dois grupos em comum com "gestão do relacionamento". As áreas predominantes pertencem a (1) engenharia, que compreendeu engenharia elétrica e engenharia de produção, (2) ciências sociais aplicadas, contemplando a área administração e (3) ciências exatas e da terra, com a área ciência da computação.

Assim, somam-se 28 grupos de pesquisa identificados nas buscas "marketing de relacionamento", "gestão de relacionamento com cliente" e "CRM". Cabe ressaltar que, destes 28 grupos, 21 pertencem à área de administração, representando $75 \%$ dos grupos; quatro pertencem às engenharias, com 14\% do total; dois pertencem à área de comunicação, somando $7 \%$ do volume total e um é pertencente à computação, representativo de $4 \%$ do total. Os dados são representados pelo Gráfico 10.

Gráfico 10 - Áreas de concentração dos grupos de pesquisa

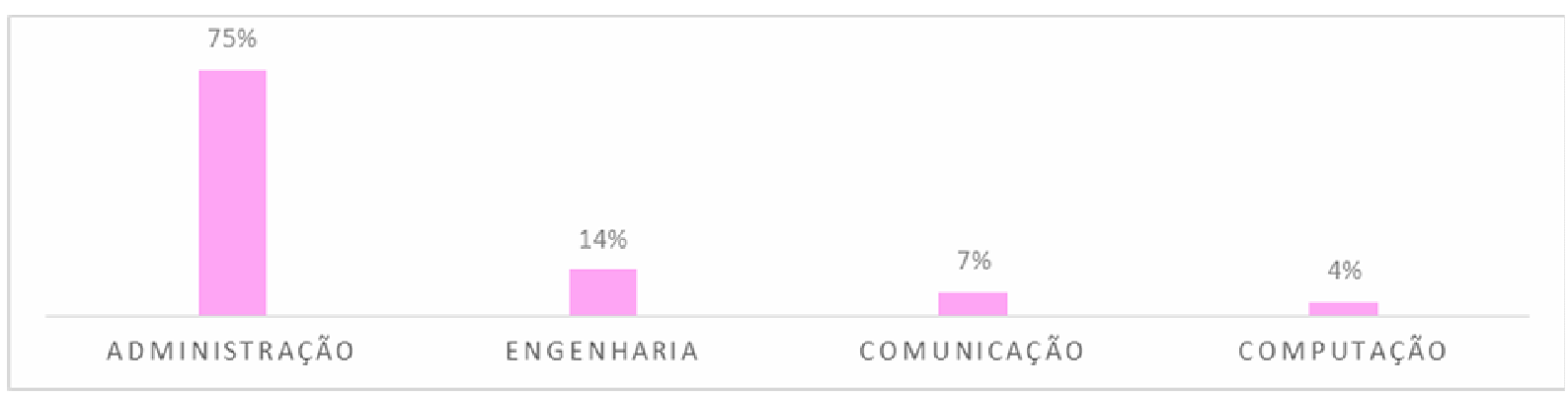

Fonte: Adaptado de consulta atual. Plataforma Lattes. Pesquisa em novembro de 2015

Os resultados obtidos por meio das buscas revelaram a existência de grupos de pesquisa na temática abordada em várias regiões do país. A distribuição geográfica destes grupos de pesquisa encontra-se no Quadro 5. 
Quadro 5 - Distribuição dos grupos de pesquisa sobre Marketing de Relacionamento, Gestão por Relacionamento ou CRM por unidade da federação e instituição

\begin{tabular}{|c|c|c|c|}
\hline ESTADO & INSTITUIÇÃO & NOME DO GRUPO & $\begin{array}{l}\text { LÍDER DO } \\
\text { GRUPO }\end{array}$ \\
\hline $\mathrm{AL}$ & UFAL & $\begin{array}{l}\text { Gestão, Marketing e Inovação em } \\
\text { Serviços de Saúde }\end{array}$ & $\begin{array}{l}\text { Carlos André } \\
\text { Silva Carneiro }\end{array}$ \\
\hline $\mathrm{CE}$ & UECE & Gestão e Estudos Organizacionais & $\begin{array}{l}\text { Ana Augusta } \\
\text { Ferreira de } \\
\text { Freitas }\end{array}$ \\
\hline $\mathrm{DF}$ & UNB & $\begin{array}{l}\text { Grupo de Pesquisas em Gestão de } \\
\text { Pessoas e Clientes }\end{array}$ & Gisela Demo \\
\hline \multirow{9}{*}{ MG } & FUMEC & Estratégia e Marketing & $\begin{array}{l}\text { José Marcos } \\
\text { Carvalho de } \\
\text { Mesquita } \\
\end{array}$ \\
\hline & UFMG & $\begin{array}{c}\text { NEECIM TUR - Núcleo de Estudos e } \\
\text { Estratégias de Comunicação Integrada } \\
\text { de Marketing \& Turismo }\end{array}$ & Marlusa Gosling \\
\hline & \multirow{2}{*}{ UNIFEI } & $\begin{array}{c}\text { Gestão Empresarial, Formação } \\
\text { Empreendedora e Intraepreendedora- } \\
\text { GEFEI }\end{array}$ & $\begin{array}{l}\text { Fábio Roberto } \\
\text { Fowler }\end{array}$ \\
\hline & & $\begin{array}{c}\text { LogTranS - Grupo de Pesquisa em } \\
\text { Logística, Transportes e } \\
\text { Sustentabilidade }\end{array}$ & $\begin{array}{l}\text { Josiane Palma } \\
\text { Lima }\end{array}$ \\
\hline & UFLA & $\begin{array}{l}\text { Marketing e Comportamento do } \\
\text { Consumidor }\end{array}$ & $\begin{array}{l}\text { Ricardo de } \\
\text { Souza Sette }\end{array}$ \\
\hline & \multirow{2}{*}{ PUC } & $\begin{array}{c}\text { GEMACONS - Grupo de Estudos em } \\
\text { Marketing, Consumo e Sociedade }\end{array}$ & $\begin{array}{c}\text { Marcelo de } \\
\text { Rezende Pinto }\end{array}$ \\
\hline & & Marketing e Competitividade & $\begin{array}{c}\text { Dalton Jorge } \\
\text { Teixeira } \\
\end{array}$ \\
\hline & \multirow{2}{*}{ UFU } & $\begin{array}{c}\text { GEPRES - Grupo de Extensão e } \\
\text { Pesquisa em Redes Sociais } \\
\end{array}$ & $\begin{array}{l}\text { Cristiane } \\
\text { Betanho }\end{array}$ \\
\hline & & $\begin{array}{c}\text { Inovação e gestão de pequenas } \\
\text { empresas }\end{array}$ & $\begin{array}{l}\text { Joao Bento de } \\
\text { Oliveira Filho }\end{array}$ \\
\hline PA & UFPA & $\begin{array}{c}\text { Inteligência Computacional e } \\
\text { Pesquisa Operacional }\end{array}$ & $\begin{array}{l}\text { Ádamo Lima de } \\
\text { Santana }\end{array}$ \\
\hline $\mathrm{PB}$ & IFPB & $\begin{array}{l}\text { Grupo de Pesquisa em Gestão e } \\
\text { Psicologia Social }\end{array}$ & $\begin{array}{l}\text { Maria de Fátima } \\
\text { Silva Oliveira }\end{array}$ \\
\hline PR & UNICENTRO & $\begin{array}{l}\text { Administração e Ciência da } \\
\text { Informação - GPACI }\end{array}$ & $\begin{array}{l}\text { Márcio Luiz } \\
\text { Bernardim }\end{array}$ \\
\hline RJ & $\mathrm{UCP}$ & Marketing Aplicado & $\begin{array}{l}\text { Katia Christian } \\
\text { Zanatta } \\
\text { Manangão }\end{array}$ \\
\hline $\mathrm{RS}$ & ULBRA & Gestão de Marketing & $\begin{array}{l}\text { Valesca Persch } \\
\text { Reichelt }\end{array}$ \\
\hline
\end{tabular}




\begin{tabular}{|c|c|c|c|}
\hline & UCS & $\begin{array}{c}\text { Grupo de Pesquisa em Estratégia e } \\
\text { Mercado - GPEM }\end{array}$ & $\begin{array}{c}\text { Gabriel } \\
\text { Sperandio Milan }\end{array}$ \\
\hline & UNISINOS & $\begin{array}{l}\text { NEME - Núcleo de Estudos em } \\
\text { Marketing e Estratégia }\end{array}$ & Guilherme Trez \\
\hline \multirow{3}{*}{ SC } & UDESC & $\begin{array}{c}\text { Grupo de Estudos e Pesquisas de } \\
\text { Marketing - GEPEM }\end{array}$ & $\begin{array}{l}\text { Aline Regina } \\
\text { Santos }\end{array}$ \\
\hline & UFSC & $\begin{array}{l}\text { NICO - Inteligência Competitiva } \\
\text { Estratégica Organizacional em } \\
\text { Marketing e Logística }\end{array}$ & $\begin{array}{l}\text { Allan Augusto } \\
\text { Platt }\end{array}$ \\
\hline & IFC & Rio Inteligente & $\begin{array}{c}\text { Fábio } \\
\text { Alexandrini }\end{array}$ \\
\hline \multirow{6}{*}{ SP } & ANHEMBI & $\begin{array}{c}\text { Gestão de Operações e Cadeia de } \\
\text { Suprimentos }\end{array}$ & $\begin{array}{c}\text { Gustavo } \\
\text { Menoncin de } \\
\text { Carvalho Pereira }\end{array}$ \\
\hline & $\begin{array}{l}\text { Centro } \\
\text { Universitário de } \\
\text { Batatais }\end{array}$ & Gestão Aplicada à Educação & $\begin{array}{l}\text { Francisco de } \\
\text { Assis Breda }\end{array}$ \\
\hline & \multirow{2}{*}{ USP } & Sistemas de Apoio à Decisão & $\begin{array}{l}\text { Edson Walmir } \\
\text { Cazarini }\end{array}$ \\
\hline & & $\begin{array}{c}\text { Markestrat - Centro de Pesquisas em } \\
\text { Marketing e Estratégia }\end{array}$ & $\begin{array}{l}\text { Marcos Fava } \\
\text { Neves }\end{array}$ \\
\hline & $\begin{array}{l}\text { Universidade } \\
\text { Nove de Julho }\end{array}$ & Estratégia em Projetos & $\begin{array}{l}\text { Marcos Roberto } \\
\text { Piscopo }\end{array}$ \\
\hline & UFSCAR & $\begin{array}{l}\text { Grupo de Estudos e Pesquisas em } \\
\text { Administração - GEPAD }\end{array}$ & $\begin{array}{l}\text { Neila Conceição } \\
\text { Viana da Cunha }\end{array}$ \\
\hline
\end{tabular}

Fonte: Plataforma Lattes, base atual, acesso em novembro de 2015 (adaptado pela autora).

A partir dos dados referentes aos grupos de pesquisa da base corrente da Plataforma Lattes, foi elaborado o Gráfico 11, com o consolidado dos anos de criação dos grupos de pesquisa sobre Marketing de Relacionamento, Gestão do Relacionamento com Cliente ou CRM até novembro de 2015, última atualização disponível. O Gráfico 11 demonstra que grupos de pesquisa são criados ininterruptamente, apresentando como anos férteis 2002, 2003, 2004, 2009, 2010 e 2011, com destaque para o ano de 2010, onde se identifica um pico de crescimento. Cabe salientar que os anos não ilustrados no gráfico foram anos em que nenhum grupo foi criado. 
Gráfico 11 - Grupos de pesquisa sobre Marketing de Relacionamento, Gestão do Relacionamento com Clientes ou CRM por ano de criação.

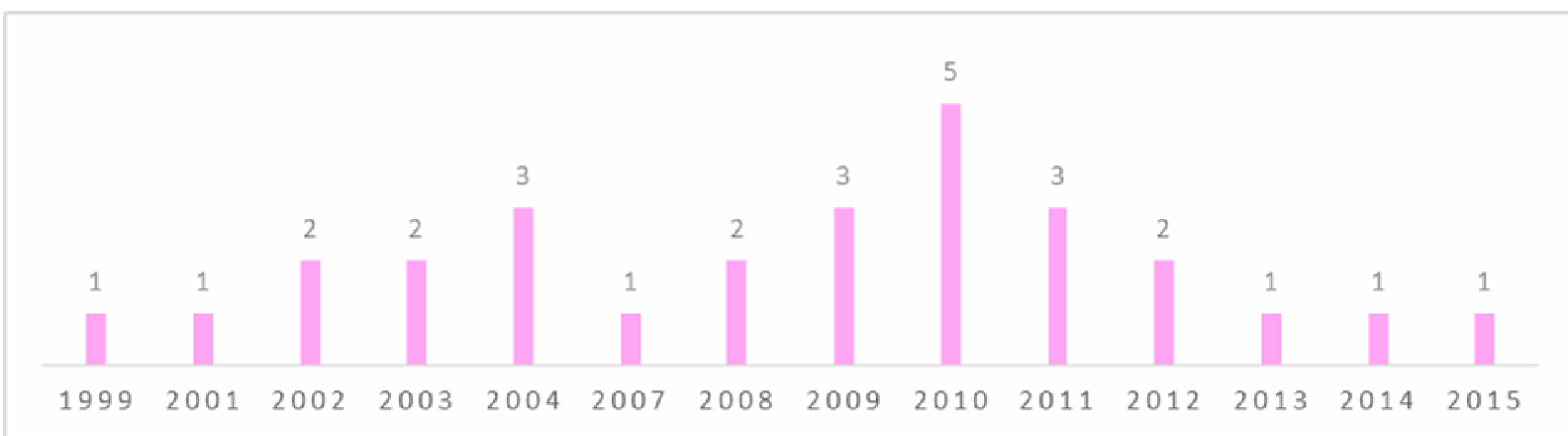

Fonte: Adaptado de consulta atual. Plataforma Lattes. Pesquisa em novembro de 2015

Com o objetivo de sintetizar a evolução temporal da capacidade instalada de pesquisa na temática marketing de relacionamento, foram investigados os indicadores de produção Científica, Técnica e de Assessoria (C, T \& A) dos censos 2000, 2002, 2004, 2006, 2008 e 2010, visto que, até novembro de 2015, data deste recorte, ainda não se dispunha de dados mais recentes. Posto isso, tem-se a procura pelas expressões "marketing de relacionamento" e "CRM", uma vez que a literatura as considera sinônimos (DEMO; ROZZETT, 2013), aplicadas simultaneamente para "título da produção C, T\&A", "referência bibliográfica" e "palavra chave da produção". Os resultados foram similares para os dois critérios de busca, observando-se aumento consistente desde o censo de 2000 até o censo de 2008, sendo que o censo 2010 revelou ligeiro decréscimo, tanto para "marketing de relacionamento" quanto para “CRM”. Estes dados estão dispostos, respectivamente, nos Gráficos 12 e 13.

Gráfico 12 - Evolução da produção C, T \& A dos grupos de pesquisa sobre Marketing de Relacionamento

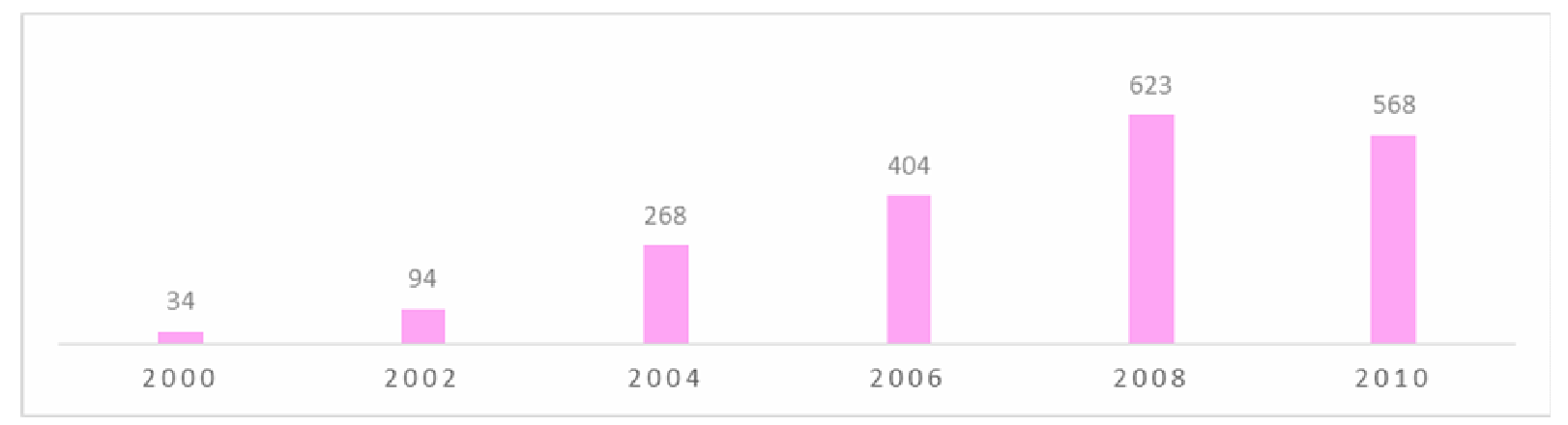

Fonte: Diretório dos Grupos de Pesquisa Lattes - Censos 2000 a 2010. 
Gráfico 13 - Evolução da produção C, T \& A dos grupos de pesquisa sobre CRM

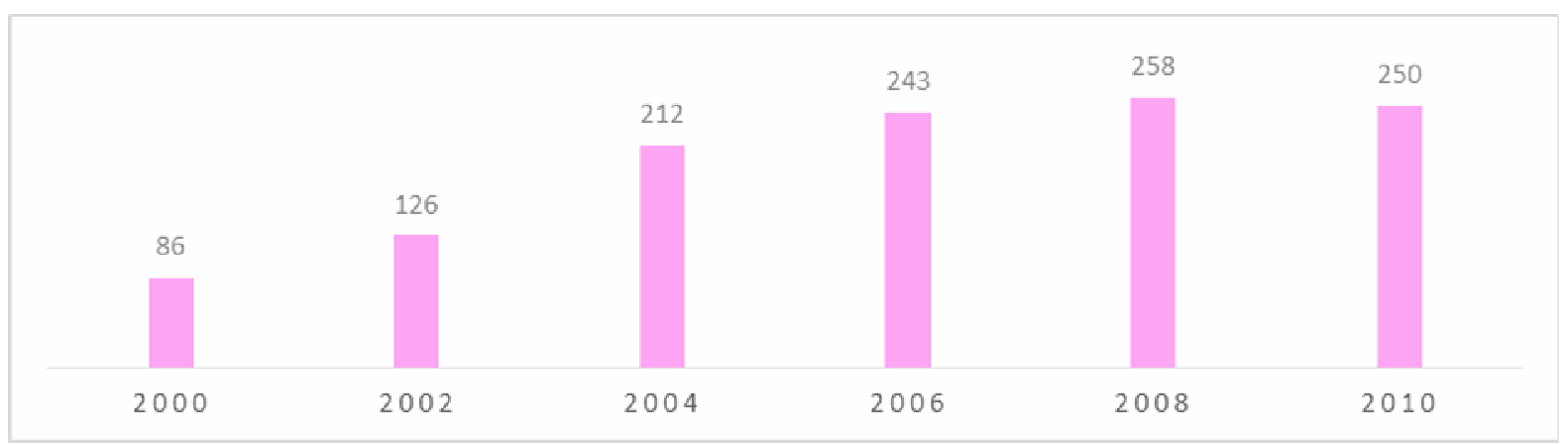

Fonte: Diretório dos Grupos de Pesquisa Lattes - Censos 2000 a 2010.

De forma a mensurar o número de pesquisadores participantes de grupos de pesquisa, bem como identificar sua formação e nacionalidade, foram realizadas três buscas distintas, sob as denominações "marketing de relacionamento", "gestão do relacionamento com cliente" e "CRM”. Os números obtidos em novembro de 2015 estão representados na Tabela 5, onde a categoria "outros" contempla mestres, graduados, estudantes ou técnicos.

Tabela 5 - Número de pesquisadores, formação e nacionalidade

\begin{tabular}{c|c|c|c|c|c}
\hline $\begin{array}{c}\text { CRITÉRIO DE } \\
\text { BUSCA }\end{array}$ & $\begin{array}{c}\text { NÚMERO } \\
\text { DE } \\
\text { GRUPOS }\end{array}$ & $\begin{array}{c}\text { TOTAL DE } \\
\text { PESQUISADORES }\end{array}$ & DOUTORES & OUTROS & ESTRANGEIROS \\
\hline $\begin{array}{c}\text { Marketing de } \\
\text { Relacionamento }\end{array}$ & 22 & 351 & 133 & 218 & 0 \\
\hline $\begin{array}{c}\text { Gestão de } \\
\text { Relacionamento } \\
\text { com Cliente }\end{array}$ & 2 & 55 & 15 & 39 & 1 \\
\hline CRM & 8 & 140 & 40 & 99 & 1 \\
\hline
\end{tabular}

Fonte: Adaptado de consulta atual. Plataforma Lattes. Pesquisa em novembro de 2015

O quadro teórico conceitual tecido para o construto marketing de relacionamento permite avaliar a importância do tema em suas implicações gerenciais e, na mesma medida, o vigor da pesquisa acadêmica na temática. Dentre os principais pontos levantados pelos estudos empíricos, fica evidente a necessidade de uma definição unificadora capaz de esclarecer a filosofia, os propósitos e os benefícios do estudo e aplicação do marketing de relacionamento. Sabe-se que o marketing de relacionamento é uma atividade de gerenciamento dos relacionamentos com os consumidores. Contudo, conforme demonstra a 
literatura, a pesquisa na área e os estudos neste campo mostram uma variedade de diferentes visões sobre o tema (GRÖNROOS, 2009). Tal interpretação é congruente com os apelos de Payne (2006), ao revelar que a limpeza conceitual vai além de um preciosismo semântico.

Considerando a mudança de paradigmas vivenciada pela disciplina de marketing (GRONROOS, 1994; SHETH; PARVATIYAR, 2002; PAYNE, 2006), a orientação para a retenção e lealdade dos clientes proposta sugere a necessidade de mudar a forma de pensar sobre marketing e de implementar marketing nas organizações (GRÖNROOS, 2009). Para o autor, o marketing de relacionamento requer uma definição que compreenda a perspectiva da criação de valor, a interação entre clientes e empresas como construto-base do marketing, a integração das várias funções organizacionais em nome do foco no consumidor e que, por fim, entenda e aplique o marketing como um processo holístico.

Sabendo que não há consenso na literatura a respeito da melhor definição para marketing de relacionamento (GRÖNROOS, 2009), para fins desta pesquisa, adota-se a seguinte definição: o marketing de relacionamento ou CRM consiste em um processo focado na utilização das informações dos clientes visando criar, desenvolver e estreitar a relação entre cliente e empresa, a fim de obter maximização do valor para os acionistas por meio do aprimoramento do valor ao consumidor e aumento do lucro da organização (PAYNE, 2006).

Em suma, neste capítulo foram apresentadas as revisões da literatura sobre as variáveis com os principais conceitos e autores, além da institucionalização de pesquisa e revisões da produção nacional, visando um embasamento sólido para a proposta de estudo. A seguir, temse a apresentação do modelo de pesquisa. 


\section{MODELO DA PESQUISA}

O modelo considerou que a personalidade de marca, composta pelas dimensões credibilidade, diversão, audácia, sofisticação e sensibilidade (MUNIZ; MARCHETTI, 2012), influencia a percepção de relacionamento das clientes (DEMO, 2014) de marcas de moda feminina de luxo. Assim, para estudar a relação entre as variáveis apresentadas, o modelo de pesquisa adotou como variável independente a personalidade de marca e, como variável dependente, a percepção do relacionamento entre marcas e clientes, representado pelo CRM, conforme revela a Figura 1.

Figura 1 - Modelo empírico da pesquisa

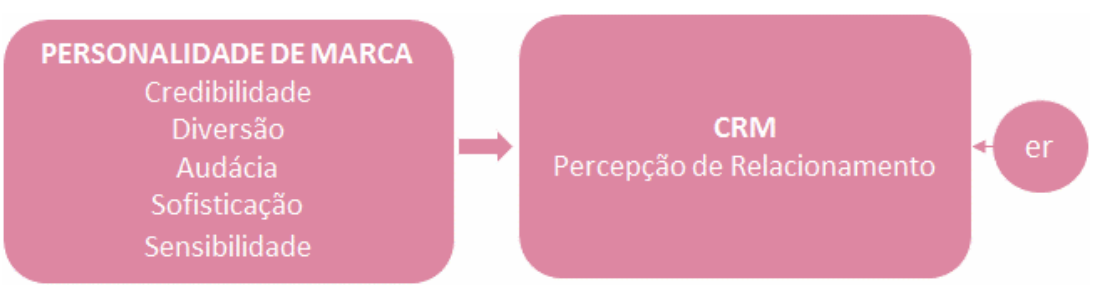

Fonte: elaborada pela autora

As variáveis pesquisadas encontram-se definidas no Quadro 6.

Quadro 6 - Variáveis da pesquisa

\begin{tabular}{|c|c|c|l|}
\hline Variável & Classificação & Fatores & \multicolumn{1}{|c|}{ Descrição } \\
\hline \multirow{2}{*}{$\begin{array}{c}\text { Personalidade de } \\
\text { Marca }\end{array}$} & \multirow{2}{*}{ Independente } & Credibilidade & $\begin{array}{l}\text { Responsável, segura, confiável, correta, respeitável, } \\
\text { leal e consistente (MUNIZ; MARCHETTI, 2012) }\end{array}$ \\
\cline { 3 - 4 } & Diversão & $\begin{array}{l}\text { Legal, feliz, festiva, extrovertida, divertida, bem- } \\
\text { humorada e brincalhona (MUNIZ; MARCHETTI, } \\
\text { 2012) }\end{array}$ \\
\cline { 3 - 4 } & Audácia & $\begin{array}{l}\text { Moderna, ousada, criativa e atualizada (MUNIZ; } \\
\text { MARCHETTI, 2012) }\end{array}$ \\
\cline { 3 - 4 } & Sofisticação & $\begin{array}{l}\text { Chique, alta-classe, elegante, sofisticada e } \\
\text { glamorosa (MUNIZ; MARCHETTI, 2012) }\end{array}$ \\
\cline { 3 - 4 } & Sensibilidade & $\begin{array}{l}\text { Delicada, sensível, romântica e encantadora } \\
\text { (MUNIZ; MARCHETTI, 2012) }\end{array}$ \\
\hline Dependente & $\begin{array}{l}\text { Percepção de } \\
\text { Relacionamento }\end{array}$ & $\begin{array}{l}\text { Percepção dos clientes quanto às iniciativas das } \\
\text { organizações no sentido de entregar produtos, } \\
\text { serviços e experiências de alto valor a fim de } \\
\text { estabelecer relacionamentos lucrativos e duradouros } \\
\text { com eles (DEMO, 2014) }\end{array}$ \\
\hline
\end{tabular}

Fonte: elaborado pela autora 
Em seguida, apresenta-se o método da pesquisa. 


\section{MÉTODO}

Serão apresentados nesta seção os procedimentos adotados na execução dos objetivos propostos neste trabalho, a saber, tipo e descrição geral da pesquisa, caracterização do setor, caracterização da amostra e, por fim, procedimentos de coleta, tratamento e análise dos dados. Cabe salientar que o método é coerente com o problema de pesquisa formulado, com os objetivos geral e específicos e com os princípios conceituais estabelecidos na fundamentação teórica.

\subsection{TIPO E DESCRIÇÃO GERAL DA PESQUISA}

Segundo Hair, Babin, Money e Samouel (2005) e Vergara (2009), o tipo de pesquisa pode ser definido em relação a seus fins e a seus meios. No que tange aos seus fins, o estudo realizado tem caráter descritivo, de acordo com seus objetivos específicos IV e V; e caráter explicativo, por conta do objetivo específico VI. Isto pode ser explicado pelo fato de a pesquisa ser baseada em observações, registro e análise de variáveis de pesquisa que buscam identificar e descrever a relação entre personalidade de marca e percepção de relacionamento.

Por conta de seu objetivo geral e dos objetivos específicos I, II e III, a pesquisa apresenta, ainda, caráter instrumental, o que converge com o objetivo de validar uma escala de pesquisa por meio de Análise Fatorial Exploratória e Confirmatória (DRENTH, 1984).

Quanto aos meios utilizados para o cumprimento dos objetivos, a pesquisa utiliza o método levantamento (survey), descrito como a obtenção de dados primários de uma grande amostra de indivíduos, cujas características, ações ou opiniões se deseja conhecer para, mediante análise quantitativa, obter as conclusões correspondentes dos dados coletados (HAIR et al., 2005).

No presente estudo, foram utilizadas técnicas qualitativas para desenvolver a escala de relacionamento com clientes e técnicas quantitativas para validá-la e também para analisar as relações entre as variáveis de pesquisa, de acordo com os objetivos estabelecidos. Cabe salientar que os dados qualitativos são necessários para se conhecer melhor aspectos que não podem ser observados e medidos diretamente, enquanto os dados quantitativos permitem a quantificação e análise dos resultados por meio de técnicas estatísticas (GODOY, 1995).

Por fim, tem-se que o horizonte temporal deste trabalho é transversal, pois os dados foram coletados em um único período de tempo (MALHOTRA, 2012). 


\subsection{CARACTERIZAÇÃO DO SETOR}

O consumo de produtos de luxo tem apresentado, desde a década de 1990, forte crescimento em todo o mundo (LIPOVETSKY; ROUX, 2005). Como consequência deste movimento, tanto a indústria de marketing quanto a academia passaram a prestar mais atenção no crescimento e no potencial do mercado de luxo (SUNG et al., 2015). Segundo a consultoria Bain \& Company (2013), os dados mais recentes obtidos sobre o mercado do luxo no mundo revelam que ele movimentou $€ 212$ bilhões em 2012, um crescimento de $10 \%$ em relação ao ano anterior, superando as expectativas, que estipulavam um crescimento de até 7\%. O Gráfico 14 ilustra o crescimento do mercado de luxo entre 1995 e 2012, último ano com resultados oficiais registrados, de acordo com suas vendas totais em todo o mundo.

Gráfico 14 - Crescimento do mercado de luxo entre 1995 e 2012 (€ bilhões)

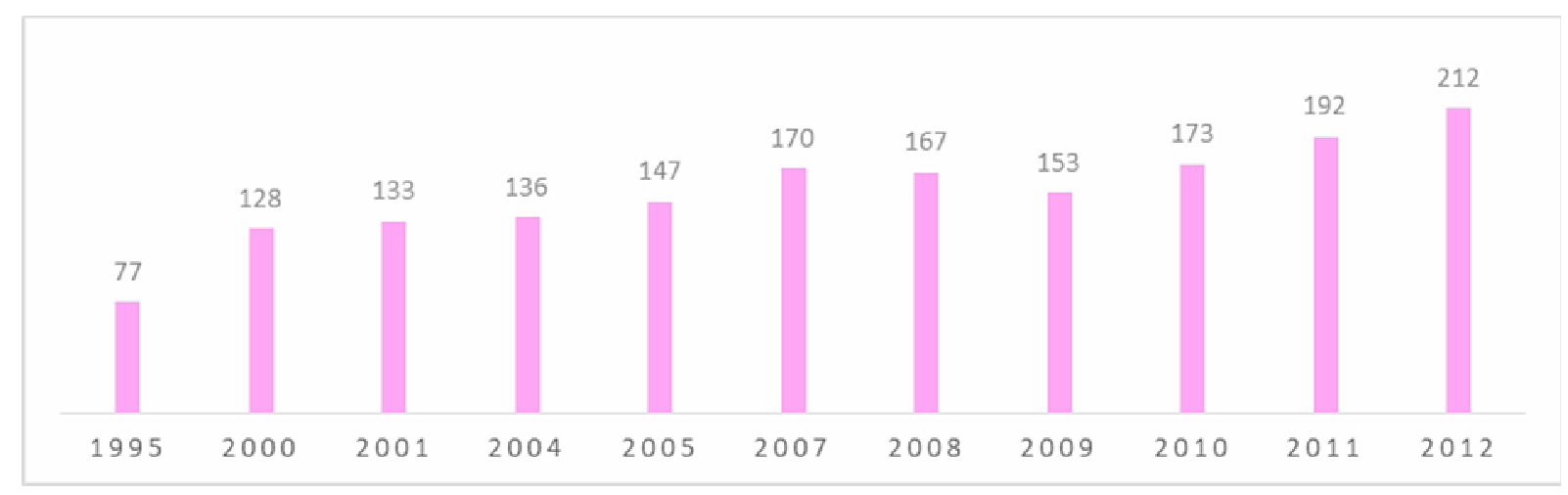

Fonte: Bain \& Company (2013)

Conforme Diniz (2012), o mercado de luxo possui como "menina dos olhos" o segmento da moda, responsável por $27 \%$ de todas as vendas no mercado de luxo no ano de 2010 e 26\% nos anos de 2011 e 2012. Segundo Moore, Doherty e Doyle (2010), as marcas de luxo no segmento de moda tornaram-se os mais valiosos e lucrativos varejistas do mundo. Cabe salientar que, entre as 100 principais marcas globais, sete marcas de moda figuram entre as marcas mais valiosas e significativas do mundo, a saber, Louis Vuitton, Gucci, Hermes, Cartier, Prada, Tiffany \& Co., e Burberry (SUNG et al., 2015). Em 2010, o segmento do luxo vendeu $€ 45$ bilhões, sendo $€ 23$ bilhões em moda feminina e $€ 22$ bilhões em moda masculina. Já em 2011, manteve a boa performance, vendendo no total $€ 48$ bilhões, um aumento de 8\% em relação a 2010. Em 2012, esse setor teve um aumento de 10\% em relação a 2011. 
Na busca por expansão de mercado, as grandes marcas de luxo voltaram-se à internacionalização de suas operações, desembarcando em mercados emergentes como a Ásia e o próprio Brasil (NUENO; QUELCH, 1998).

O Brasil consiste em um país comercializador de produtos de luxo, visto que não se encontra tradição neste segmento no país (PIANARO; MARCONDES, 2008). De acordo com MCF e GfK (2012), este mercado registrou faturamento em torno de R $\$ 6,86$ bilhões no Brasil em 2006. Já no ano de 2007, obteve um crescimento de $28 \%$ atingindo a marca de $\mathrm{R} \$$ 8,79 bilhões em vendas. Ao final do ano de 2008, o país continuou com um crescimento no mercado de luxo na casa dos $20 \%$, arrecadando $\mathrm{R} \$ 10,53$ bilhões, ou seja, $\mathrm{R} \$ 1,74$ bilhão a mais do que registrado em 2007. Em 2009, a chegada ao país das marcas Hermès, Missoni, Christian Louboutin, Bentley, Lamborghini e Bugatti, que investiram juntas US\$ 830 milhões, revelou que a crise financeira não teve impacto negativo no consumo brasileiro de luxo. Nos anos de 2010, 2011 e 2012, o Brasil também registrou crescimento de 41,38\%. O Gráfico 15 ilustra o crescimento das vendas do mercado de luxo brasileiro.

Gráfico 15 - Crescimento do mercado de luxo no Brasil entre 2006 e 2012 (R \$ bilhões)

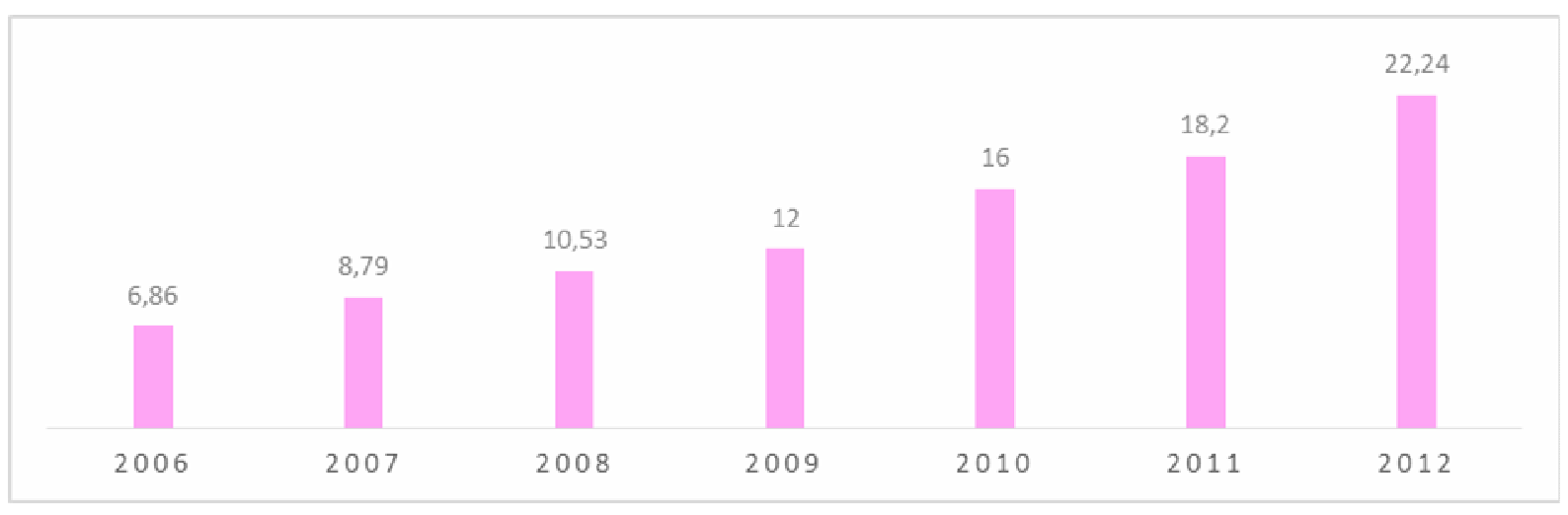

Fonte: MCF e GfK (2012)

O cenário descrito para o mercado de luxo brasileiro é atribuído não somente aos aspectos econômicos supracitados, mas também à forma como as marcas e produtos de luxo tem-se tornado acessíveis ao consumidor brasileiro, sendo que o acesso da classe média ao luxo endossa esta expansão (D’ ANGELO, 2006). Para o autor, a transformação dos hábitos de compra do brasileiro tem relação direta com a ascensão social, apoiada na necessidade de aquisição de símbolos que traduzam à sociedade o bom momento vivido pelos indivíduos. Esta ascensão corrobora com os fatores que sustentam o crescimento do mercado de luxo, como o desenvolvimento de classes mais ricas em países em desenvolvimento, o aumento do 
poder de compra entre as mulheres e a redução dos custos de produção (FIONDA; MOORE, 2009). Para Atwal e Williamns (2009), as marcas de luxo estão se tornando acessíveis a grupos cada vez mais democráticos de consumidores.

Entre as características marcantes do público brasileiro consumidor de luxo, reside a forte atração por novidades, visto que consome tendências e busca marcas internacionais, o que contribui para a expansão de diversas grifes estrangeiras em solo brasileiro, especialmente na cidade de São Paulo (KINKLE, 2005). O autor revela, ainda, que é nesta disposição do brasileiro em consumir luxo que reside a projeção de crescimento do setor.

É preciso considerar ainda a facilidade de pagamento observada no Brasil, que afeta positivamente o consumo de itens de luxo (PIANARO; MARCONDES, 2008). Neste ponto, destaca-se que o crescimento do consumo de moda de luxo não foi sustentado pelos consumidores ricos, mas sim pela classe média (D’ANGELO, 2006). Para o autor, os ricos constituem uma minoria que pode consumir apenas o luxo, enquanto os demais - descendo a escala social até chegar ao degrau da classe média - precisam fazer escolhas.

Ademais, ainda que a ascensão da classe média seja uma forte motivação para este segmento no país, é necessário também considerar o volume de ricos e milionários residentes no Brasil, número que deve crescer, segundo Diniz (2012), devido aos novos milionários do agronegócio, atletas, pessoas do setor de entretenimento e empreendedores. De acordo com o relatório sobre riqueza mundial (CAPEGEMINI; RBC, 2012), o número de milionários no Brasil aumentou em 6\% no ano de 2012, colocando o país entre as 12 nações mundiais com o maior número de indivíduos neste perfil.

Em uma pesquisa para identificar as principais tendências de comportamento para 2014, a rede britânica BBC revelou, em janeiro de 2014, que o consumo de luxo configura um dos principais comportamentos da população mundial. Revelou-se, ainda, que consumidores com alto poder aquisitivo tendem a manter seus padrões de compra, enquanto outros milhares de consumidores manifestaram interesse de adquiri-los, especialmente nos mercados emergentes, com destaque para o público feminino, impulsionado pelas facilidades de crédito.

Neste sentido, Diniz (2012) argumenta que o Brasil está se destacando aos poucos como mercado emergente de luxo, de forma mais aspiracional e sensorial. O autor revela, ainda, que os consumidores de luxo brasileiro requerem cuidados, pois buscam produtos e serviços que deem sentido ao seu estilo de vida, estando dispostos a pagar mais e serem fieis, estabelecendo relacionamentos de longo prazo com as marcas de luxo. 
Apesar da notória relevância do segmento para a economia e para o mercado, a indústria da moda de luxo ainda carece de estudos. Para Sung et al. (2015), as pesquisas sobre o setor tendem a focar na criação e implementação de modelos de negócios eficientes, em estratégias de loja-conceito ou modelos de negócios internacionais. Os autores ressaltam, também, que estes estudos se limitam a algumas poucas marcas de moda de luxo. Considerando esta lacuna e, principalmente o cenário brasileiro descrito, tanto na dimensão econômica quanto na social, tem-se um mercado favorável para a ampliação dos negócios neste nicho, justificando a relevância de pesquisas no setor.

A seguir, a metodologia referente à população e amostra, instrumentos de pesquisa e procedimentos de tratamento e análise de dados será exposta de acordo com cada etapa desta pesquisa, a saber, estudo qualitativo e estudo quantitativo.

\subsection{ESTUDO QUALITATIVO}

\subsubsection{População e amostra}

Uma população é a soma de todos os elementos que compartilham algum conjunto de características, formando o universo para o propósito do problema de pesquisa (MALHOTRA, 2012). Neste sentido, o autor aponta que a amostra é um subgrupo dos elementos de uma população utilizado para a pesquisa.

$\mathrm{Na}$ etapa qualitativa, a amostra contemplou gestores e consumidoras de marcas de moda feminina de luxo. O número de participantes foi baseado nos princípios de Bardin (2014), que sugere que, em pesquisas descritivas, a quantidade de participantes constitua um grupo variado e representativo. Como a pesquisa qualitativa não propõe um número ideal de participantes, a definição do número de entrevistados seguiu o critério de saturação ou exaustividade, que ocorre quando as respostas começam a se repetir e não são mais gerados novos dados, determinando que a amostra é suficiente (BARDIN, 2014).

Para Fraser e Gondim (2004), o critério mais importante a ser considerado no processo de seleção de entrevistados não é numérico, já que a finalidade não é apenas quantificar opiniões, e sim explorar e compreender os diferentes pontos de vista de determinado contexto. Salienta-se que o número de entrevistados abarcou os objetivos da pesquisa e, principalmente, a possibilidade de esgotamento do tema (GASKELL, 2002). 


\subsubsection{Caracterização da amostra}

A etapa qualitativa contemplou uma amostra de 14 participantes, sendo dez consumidoras e quatro gestores de marcas de moda feminina de luxo.

As consumidoras entrevistadas foram identificadas por meio de contatos pessoais da pesquisadora e, ainda, através de redes sociais. As participantes desta etapa tinham idade entre 29 e 49 anos, residentes das cidades de Balneário Camboriú/SC, Florianópolis/SC, Rio de Janeiro/RJ e São Paulo/SP; todas com ensino superior completo.

A amostra de gestores de marcas de moda feminina entrevistados foi composta por três mulheres e um homem, funcionários das marcas Mixed, Thelure, Prada e Louis Vuitton e foram abordados por meio de contatos pessoais da pesquisadora. Quanto aos cargos, tem-se um proprietário, um franqueado, um gerente de relacionamento e um gerente de operações no Brasil.

\subsubsection{Instrumento de pesquisa}

Para o desenvolvimento e validação da Escala de Relacionamento com Clientes no mercado de luxo, a ERC Luxo, foram realizadas 14 entrevistas com gestores e consumidoras do mercado de moda feminina se luxo.

Manzini (2004) sugere que as entrevistas semi-estruturadas sejam direcionadas por um roteiro previamente elaborado, composto por questões abertas, ou seja, por um roteiro de questões que orientem a interação entre entrevistador e entrevistado, mas deixando espaço para que informações extras ou mais comentários sejam adicionados.

O roteiro serviu, desta forma, para coletar informações básicas e como um meio para o pesquisador organizar o processo de interação com o informante, sendo indicado para buscar informações a respeito de opiniões, concepções, expectativas, percepções sobre objetos ou fatos (MANZINI, 2004). As questões do roteiro foram construídas de acordo com os objetivos da pesquisa e com base na literatura pesquisada (ALLÉRÈS, 2000; CASTARÉDE, 2005; DEMO; ROZZETT, 2013; FOURNIER, 1998; ROZZETT; DEMO, 2010). O roteiro utilizado nesta etapa encontra-se no Apêndice A.

\subsubsection{Procedimentos de coleta, tratamento e análise de dados}

No que tange à coleta de dados, esta foi realizada a partir de entrevistas semiestruturadas com gestores e consumidoras de marcas de moda feminina de luxo, com base em roteiro de entrevistas, seguindo as orientações de Manzini (2004). 
A pesquisa qualitativa foi realizada nos meses de março, abril e maio de 2015 . O mês de março foi destinado ao levantamento de possíveis entrevistados e ao envio de convite com detalhamento da pesquisa. Todos os participantes assinaram um termo de consentimento, autorizando a gravação das entrevistas, sendo que este documento se encontra no Apêndice B deste estudo.

Em seguida, realizou-se a transcrição das entrevistas. A saber, todas as entrevistas e as transcrições das mesmas foram realizadas pela pesquisadora.

Quanto à técnica de análise de dados, utilizou-se a análise de conteúdo categorial temática proposta por Bardin (2014), onde o conteúdo das entrevistas deve ser classificado, segundo sua frequência, em categorias temáticas. Vale ressaltar que a análise de conteúdo consiste em um conjunto de técnicas de análise das comunicações, que utiliza procedimentos sistemáticos e objetivos de descrição do conteúdo das mensagens (BARDIN, 2014). Assim, da análise de conteúdo, surgiram aspectos relevantes no estabelecimento de relacionamentos de longo prazo entre consumidoras e as marcas de moda feminina de luxo. Tais aspectos ajudaram a compor a versão de aplicação do instrumento de mensuração da variável percepção de relacionamento.

Após a realização das entrevistas e compilação dos dados, seguiu-se à elaboração do questionário, visando à etapa quantitativa do estudo.

\subsection{ESTUDO QUANTITATIVO}

\subsubsection{População e amostra}

Para a etapa quantitativa, o público-alvo contemplou as consumidoras de marcas de moda feminina de luxo, residentes no Brasil. A amostra caracteriza-se como não probabilística e por conveniência (adesão), utilizando-se coleta online (pela internet) e face a face. Uma vez que a população de consumidoras de marcas de moda feminina de luxo tende ao infinito, a amostra pode ser não probabilística (COCHRAN, 1977). A amostra é, ainda, considerada por conveniência visto que contempla a seleção de elementos que estejam mais disponíveis para tomar parte do estudo e que possam oferecer informações necessárias (HAIR et al., 2005).

Neste estudo, foram usadas duas amostras independentes. A primeira destinou-se à análise fatorial exploratória, contemplando o objetivo II, validar a escala de relacionamento com clientes de marcas de moda feminina de luxo. A segunda amostra foi utilizada para a 
validação confirmatória que, por sua vez, consiste no objetivo III do estudo, e também para a análise da relação entre as variáveis, de forma que se possa verificar o ajuste de um modelo estrutural de medição, proposto no objetivo VI.

No que tange ao tamanho da primeira amostra, Tabachnick e Fidell (2013) apontam que o tamanho da amostra para análise fatorial exploratória contemple um mínimo de 300 indivíduos, sugerindo, ainda, como regra, entre 5 e 10 sujeitos por item do questionário. Para o dimensionamento do tamanho da segunda amostra, para a análise fatorial confirmatória, Hair, Black, Babi, Anderson e Tatham (2009), Kline (2011) e Byrne (2013) sugerem entre 10 e 20 sujeitos por variável.

Já no que tange à verificação da predição entre as variáveis, será utilizada a análise de caminhos (path analysis). Neste sentido, é importante selecionar uma amostra mínima que tenha poder estatístico maior que 0,80 (COHEN, 1992), no caso das ciências comportamentais. Segundo o autor, a análise do poder estatístico considera as relações entre as três variáveis envolvidas em inferência estatística, a saber, tamanho da amostra $(\mathrm{N})$, critério de significância $(\alpha)$, efeito do tamanho da população (ES) e poder estatístico. Por meio do programa GPower 3.1 e considerando a variável preditora, personalidade de marca, com cinco dimensões, obteve-se a amostra mínima, com $\alpha=0,05$, ES médio e 5 preditores, de 138 sujeitos.

Ainda, Kline (2011) afirma que, para modelos simples, com poucas variáveis, como no caso deste estudo, para utilizar a análise de caminhos por meio da Structural Equation Modeling - SEM (Modelagem por Equações Estruturais), a amostra média entre 100 e 200 sujeitos é o mínimo recomendado. Conforme propõe Kline (2011), considerando três observações e três parâmetros, ou seja, zero graus de liberdade, tem-se um modelo recursivo, classificado como identificado (just identified), sendo adequado para teste por meio da modelagem por equações estruturais, usando o critério de máxima verossimilhança (KLINE, 2011).

Seguindo as recomendações da literatura, estimou-se um mínimo de 300 sujeitos para a primeira amostra e de 200 sujeitos para a segunda amostra. Considerando uma margem de segurança por conta da etapa de tratamento de dados, a amostra total obtida para o estudo quantitativo contemplou 801 sujeitos, sendo que, destes, 527 responderam ao questionário disponibilizado online e 274 completaram de forma presencial. Estas duas amostras, online e presencial foram analisadas para verificar a homogeneidade da amostra total, o que de fato ocorreu, haja vista que nas duas amostras, a maioria dos respondentes têm idade entre 18 e 28 
anos, possuem ensino superior completo, são clientes da marca de luxo escolhida entre 1 e 5 anos e adquirem produtos desta marca com frequência anual.

\subsubsection{Tratamento dos dados}

O tratamento dos dados teve início com análise de distribuição de frequências (média, desvio-padrão, variância, máximo e mínimo), visando confirmar a precisão da transcrição dos dados. Na sequência, utilizou-se o procedimento listwise para a análise de dados faltantes (missing values), que consiste na eliminação de questionários que apresentaram algum item em branco (TABACHNICK; FIDELL, 2013). Nesta etapa, foram contabilizadas 105 perdas em razão de questionários incompletos.

A investigação quanto à presença de outliers, valores que diferem substancialmente da média e da maioria dos dados, foi realizada pelo método Mahalanobis, conforme orientação de Tabachnick e Fidell (2013). Com base na verificação da tabela do qui-quadrado, com índice de significância $\mathrm{p}<0,001$ e considerando 68 variáveis, obteve-se o valor de $\mathrm{X}^{2}=$ 112,317 e, assim, foram eliminados 74 outliers. Portanto, tem-se uma amostra final de 622 sujeitos.

Foram realizadas as análises de multicolinearidade e de singularidade, que não apresentaram problemas para a amostra pesquisada, visto que os valores de tolerância foram superiores a 0,1 e os valores referentes ao fator de inflação de variância foram superiores a 10,0 (MYERS, 1990).

Por fim, partiu-se para a análise dos pressupostos para a utilização da análise multivariada, de acordo com Hair et al. (2009). Desta forma, foram gerados gráficos de probabilidade normal e gráficos de resíduos com o intuito de verificar normalidade, linearidade e homocedasticidade dos dados. Todos os pressupostos foram confirmados.

Tem-se, assim, uma amostra final composta por 622 sujeitos que atenderam aos critérios estatísticos supracitados. Esta amostra final foi então dividida aleatoriamente em duas amostras distintas, a primeira, destinada à análise fatorial exploratória (Estudo 1), composta por 300 sujeitos; e a segunda, referente à análise fatorial confirmatória (Estudo 2) e à análise de caminhos, composta por 322 sujeitos. Cabe ressaltar que, para o Estudo 2, onde foi utilizada a modelagem por equações estruturais, analisou-se, ainda, a normalidade multivariada no programa Amos, a qual também não apresentou problemas. Ainda, para consecução dos objetivos IV e V da pesquisa, foi utilizada a amostra total de 622 participantes. 


\subsubsection{Caracterização da amostra}

A amostra foi caracterizada em termos de idade, escolaridade, há quanto tempo o sujeito era cliente da marca e a frequência de compra dos produtos da mesma. Visto que os estudos contemplam amostras independentes, estas serão caracterizadas separadamente. Ainda, tem-se a descrição das marcas de moda feminina de luxo mais citadas em cada amostra.

\section{Estudo 1}

O Estudo 1, referente à validação exploratória da ERC Luxo, contou com uma amostra de 300 sujeitos.

Em se tratando da idade das participantes, $19,3 \%$ possuem entre 18 e 28 anos; 49,7\% possuem entre 29 e 39 anos; 19,33\% apresentaram idade entre 40 e 50 anos e, por fim, 8\% apresentaram idade entre 50 e 80 anos. Cabe salientar que tais percentuais não somam $100 \%$, visto que nem todos os sujeitos (3,7\% da amostra) responderam a esta questão.

No que diz respeito à escolaridade, foi pedido que as participantes selecionassem o grau de escolaridade completa, onde as opções variaram entre ensino fundamental e doutorado. De acordo com o Gráfico 16, observa-se que a maior parte das respondentes têm pós-graduação/MBA completa, representando 47\%. Destacam-se, ainda, o nível superior com $31 \%$ e mestrado, representando $15 \%$.

Gráfico 16 - Grau de escolaridade das participantes do Estudo 1

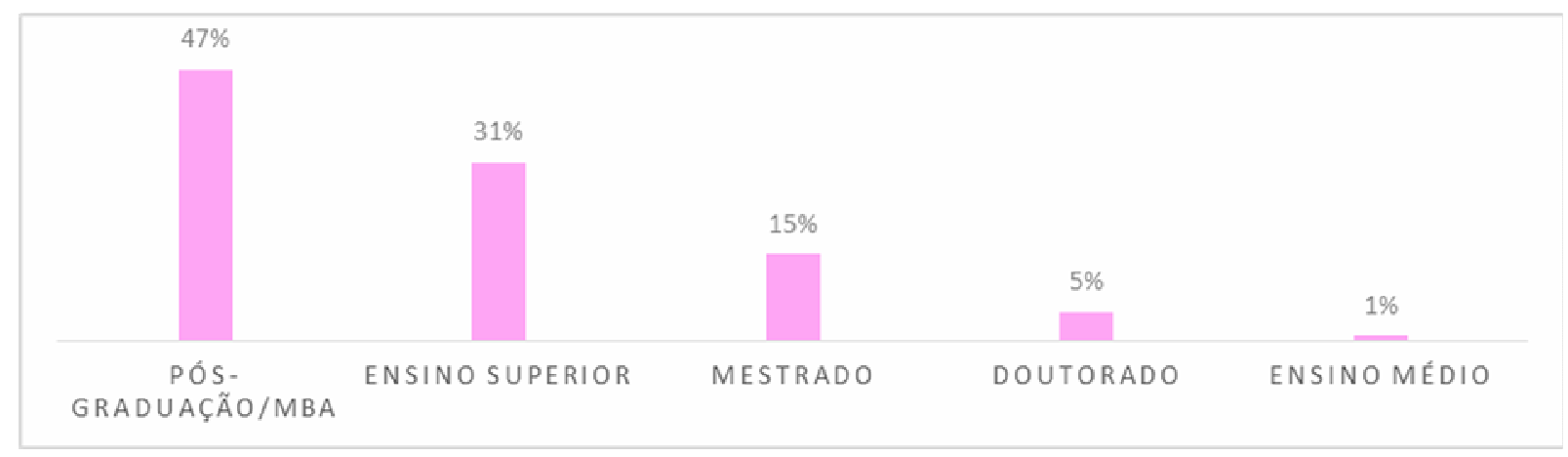

Fonte: Elaborado pela autora

$\mathrm{Na}$ sequência, as participantes foram questionadas quanto ao tempo em que eram clientes da marca de moda feminina de luxo escolhida. Conforme ilustra o Gráfico 17, 51\% 
responderam que se relacionam com a marca entre 1 e 5 anos, seguida do período entre 5 e 10 anos, com $30 \%$ de representatividade. As clientes há mais de 10 anos representam $12 \%$ do total, enquanto as clientes recentes, há menos de um ano, consistem em $6 \%$ da amostra. 
Gráfico 17 - Tempo de relacionamento das participantes do Estudo 1 com as marcas escolhidas

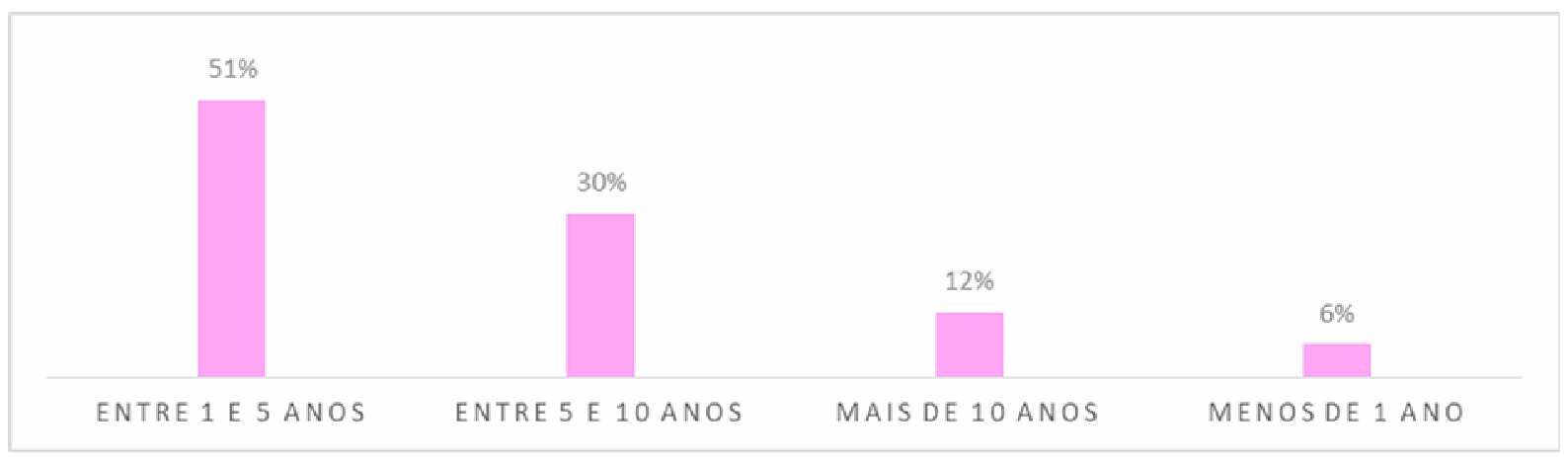

Fonte: Elaborado pela autora

Por último, foi solicitado às participantes que revelassem a frequência de compra da marca escolhida. Como pode ser observado no Gráfico 18, a maior parte delas consome produtos da marca anualmente, representando $56 \%$ do total. $\mathrm{Na}$ sequência, figuram as compras periódicas, com intervalos maiores que um ano, com $23 \%$ de representatividade. Ademais, $14 \%$ das clientes realizam compras mensalmente e apenas $7 \%$ efetuam compras raramente.

Gráfico 18 - Frequência de compra das participantes do Estudo 1

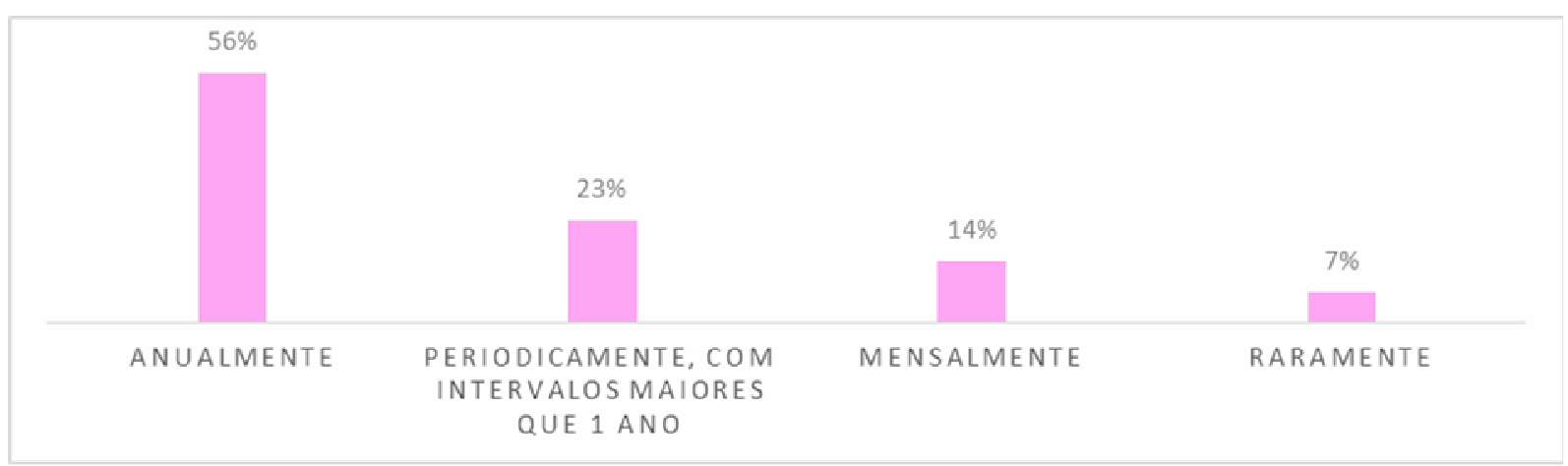

Fonte: Elaborado pela autora

\section{Estudo 2}

O Estudo 2, referente à validação confirmatória da ERC Luxo e o teste do modelo estrutural, contou com uma amostra de 322 sujeitos. 
No que tange à idade das participantes, verificou-se que $75 \%$ delas apresentam idade entre 18 e 28 anos. As respondentes com idade entre 29 e 39 anos representam 19\% da amostra, enquanto que, entre 40 e 50 anos constituem $4 \%$ do total.

A respeito da escolaridade das participantes, a maioria delas, com $47 \%$, tem ensino superior completo, seguida do ensino médio, cujo volume é de $46 \%$ do total. Participantes com pós-graduação/MBA somam $5 \%$ a amostra, enquanto $2 \%$ representam as com mestrado. Tais resultados são expostos pelo Gráfico 19.

Gráfico 19 - Grau de escolaridade das participantes do Estudo 2

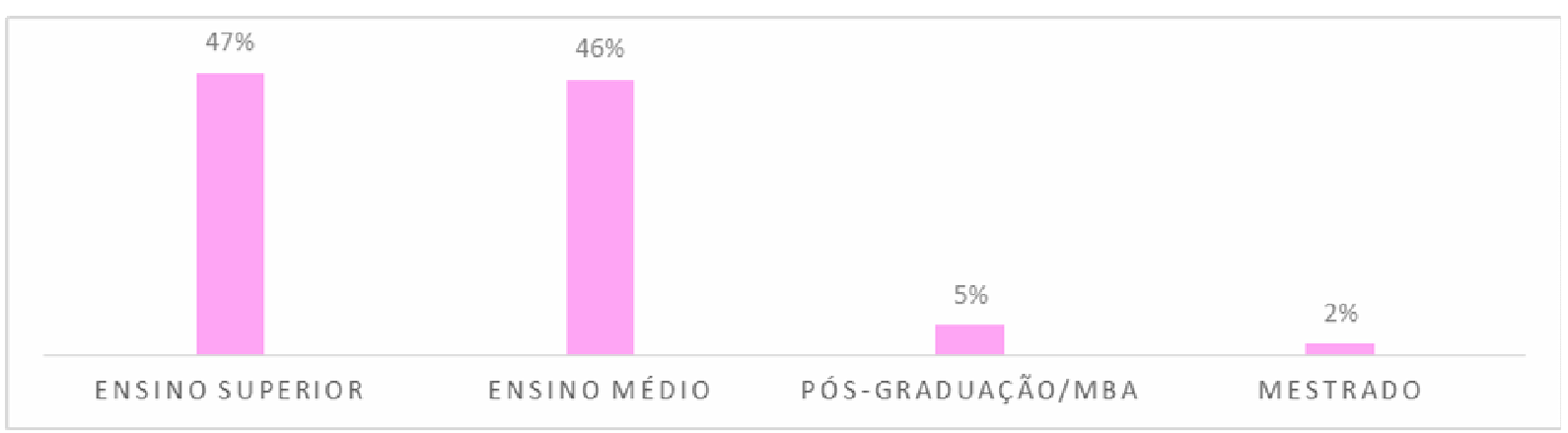

Fonte: Elaborado pela autora

A questão que se segue trata do tempo de relacionamento que a cliente tem com a marca de moda feminina escolhida. Segundo ilustrado pelo Gráfico 20, a maior parte das respondentes relaciona-se com a marca entre 1 e 5 anos, volume que representa $68 \%$ do total. Na sequência, figuram o período entre 5 e 10 anos, representando $16 \%$ e o período inferior a um ano, com $11 \%$ do total. Apenas $5 \%$ das clientes compram produtos das marcas escolhidas há mais de dez anos.

Gráfico 20 - Tempo de relacionamento das participantes do Estudo 2 com as marcas escolhidas

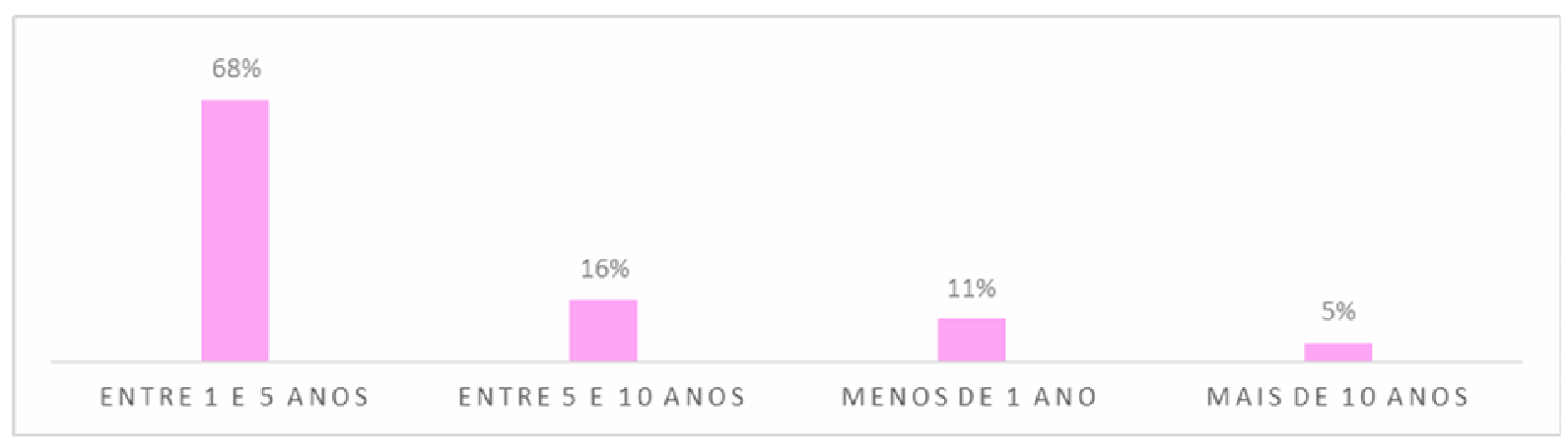

Fonte: Elaborado pela autora 
Por fim, buscou-se identificar a frequência de compra da marca de moda feminina escolhida. Assim, a maior parte das respondentes, somando $42 \%$ da amostra, realiza compras anualmente, seguido pelas compras periódicas, com intervalos superiores a um ano, representando $23 \%$ do dotal. Ainda, com $17 \%$ de representatividade cada, tem-se as frequências mensalmente e raramente. Os resultados encontram-se ilustrados no Gráfico 21.

Gráfico 21 - Frequência de compra das participantes do Estudo 2

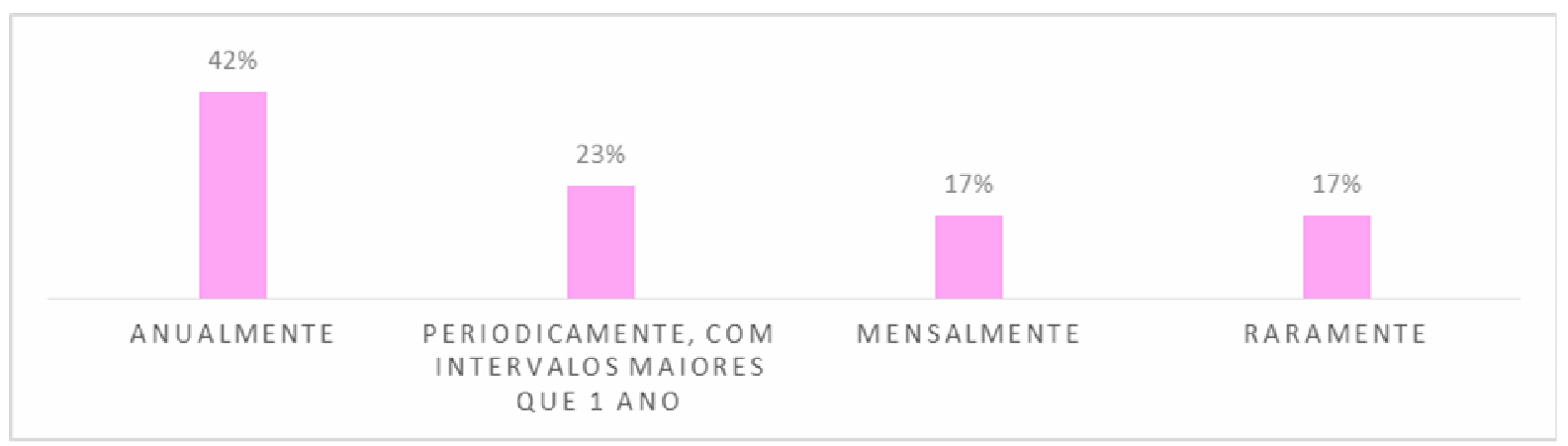

Fonte: Elaborado pela autora

\section{Caracterização da amostra total}

Visto que o cumprimento dos objetivos específicos IV e $\mathrm{V}$, respectivamente, identificar a personalidade atribuída às marcas de moda feminina de luxo mais citadas pelas clientes pesquisadas e identificar a percepção que as clientes de marcas de moda feminina de luxo possuem quanto ao seu relacionamento com elas, deu-se a partir da amostra total de 622 respondentes, torna-se necessário caracterizar tal amostra.

No que tange à idade das participantes, 49\% delas tem entre 18 e 28 anos; 34\% entre 29 e 39 anos; $11 \%$ entre 40 e 50 anos e, por fim, as mulheres com idade entre 50 e 80 anos somam $4 \%$ da amostra pesquisada.

Sobre a escolaridade das respondentes, conforme o Gráfico 22, verificou-se que sua maioria tem ensino superior completo, compondo $39 \%$ do total, enquanto que $25 \%$ delas tem pós-graduação/MBA. Na sequência, estão as respondentes com ensino médio completo, $24 \%$ do total. Por fim, as clientes de marcas de moda feminina de luxo com mestrado ou doutorado são representativas, respectivamente, de $8 \%$ e $3 \%$ da amostra. Isto revela que há prevalência do ensino superior e pós-graduação, mostrando, em última análise, que quanto melhor o emprego, maior é a renda e, assim, o consumo de produtos de luxo. 
Gráfico 22 - Grau de escolaridade da amostra total

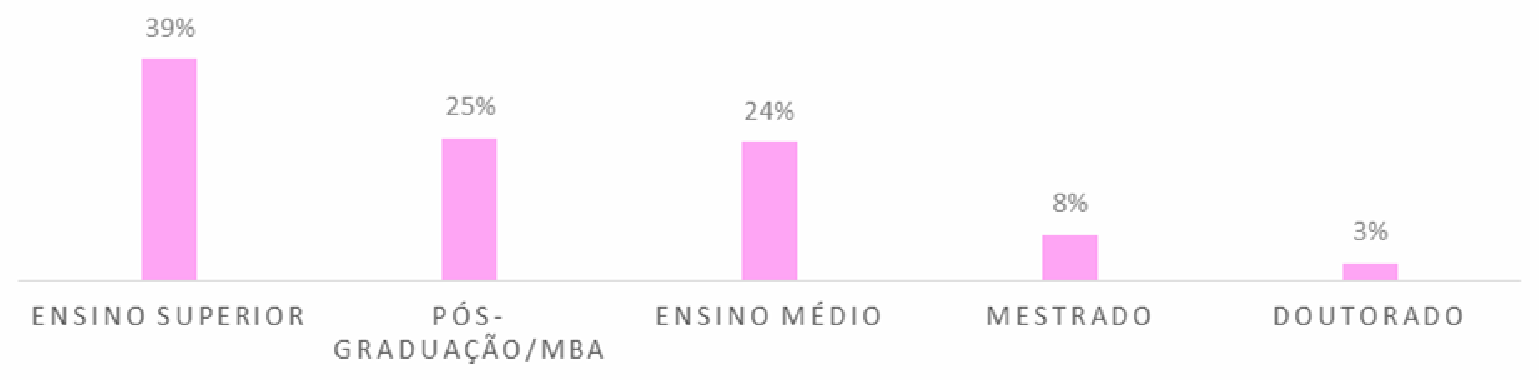

Fonte: Elaborado pela autora

Em relação ao tempo de relacionamento que a cliente tem com a marca de moda feminina escolhida, observa-se que $60 \%$ das respondentes são clientes das marcas há entre 1 e 5 anos, enquanto $23 \%$ relacionam-se com a marca há entre 5 e 10 anos. O volume de clientes cujo relacionamento é recente, há menos de um ano, é de $9 \%$, enquanto o volume de clientes com relacionamentos duradouro, há mais de dez anos, é de $8 \%$ da amostra. Tais informações encontram-se ilustradas no Gráfico 23.

Gráfico 23 - Tempo de relacionamento das participantes com as marcas escolhidas

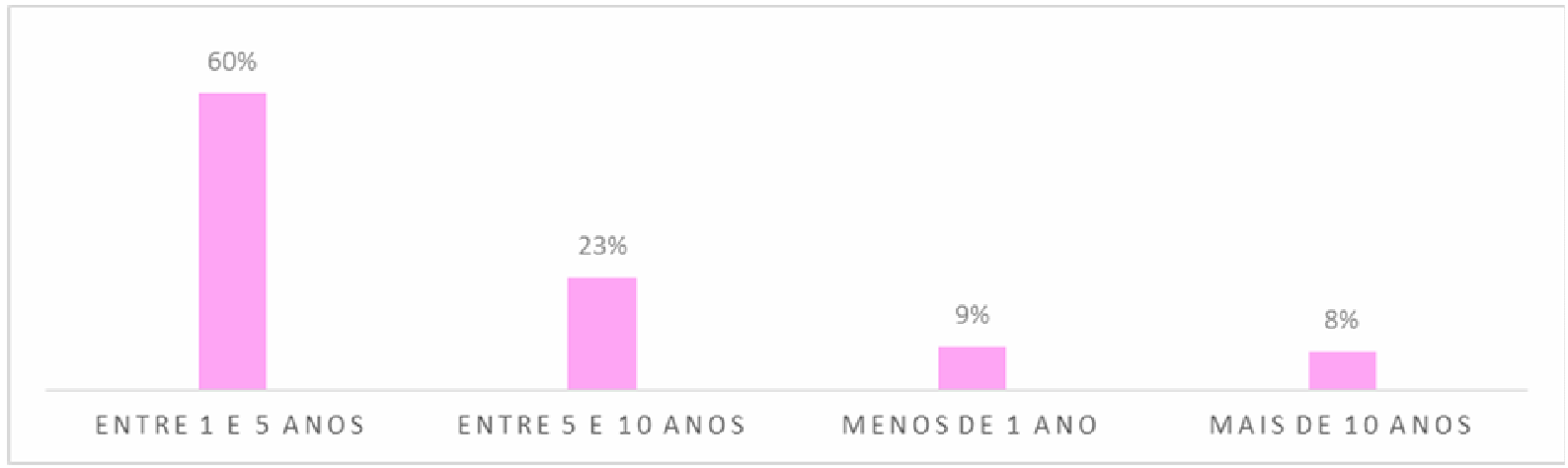

Fonte: elaborado pela autora

Por fim, em se tratando da frequência de compra, o Gráfico 24 ilustra que as participantes, em sua maioria (49\%), apresentam frequência de compra anual, enquanto $23 \%$ compram produtos da marca de forma periódica, com intervalos superiores a um ano. No que tange à frequência de compra mensal, esta é realizada por $16 \%$ das respondentes e, do outro extremo, tem-se que $12 \%$ das participantes compram raramente as marcas escolhidas. 
Gráfico 24 - Frequência de compras das participantes do estudo

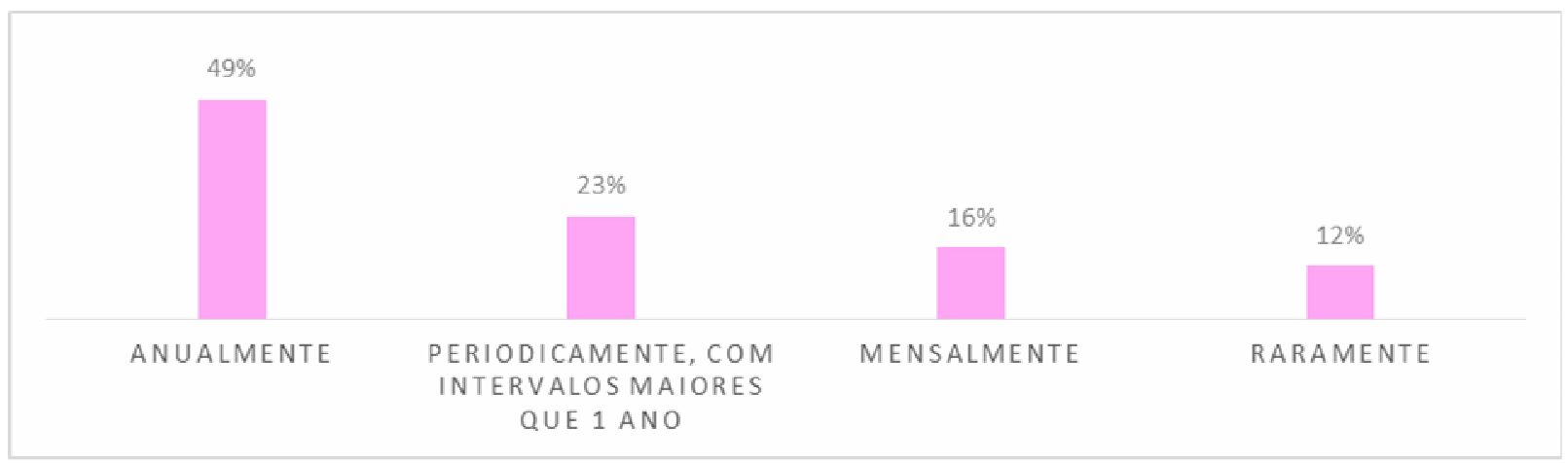

Fonte: elaborado pela autora

\subsubsection{Instrumento de pesquisa}

O questionário aplicado às consumidoras de moda feminina de luxo foi construído com base em dois instrumentos de pesquisa, a saber, a Escala de Relacionamento com Clientes no mercado de luxo, desenvolvida e validada no presente estudo; e a Escala de Dimensões de Personalidade de Marca, validada no contexto brasileiro por Muniz e Marchetti (2012).

Com a realização das entrevistas com gestores e consumidoras de marcas de moda feminina de luxo e a partir da análise de conteúdo das mesmas, foram desenvolvidos os itens do questionário referentes ao mercado de luxo a serem incluídos na Escala de Relacionamento com Clientes - ERC desenvolvida e validada por Demo e Rozzett (2013).

O instrumento piloto, composto por 46 itens, foi submetido à análise semântica, seguindo as orientações da literatura (KERLINGER; LEE, 2008; PASQUALI, 2012), em que uma amostra de 20 consumidoras de marcas de moda feminina de luxo avaliou a clareza dos itens. Simultaneamente, ocorreu a análise de juízes, revisão do questionário por especialistas sugerida por Richardson (1999), onde oito especialistas em marketing, analisaram se os itens propostos se referiam ao construto relacionamento, no caso específico dos consumidores de marcas de moda feminina de luxo.

Desta forma, como resultado das análises supracitadas, a versão de aplicação da ERC Luxo contou com 40 itens sobre CRM, avaliados por meio de uma escala de concordância tipo Likert, variando entre pontos extremos de 1 (discordo totalmente) a 5 (concordo totalmente), sendo 3 o ponto neutro da escala (MALHOTRA, 2012). 
A Escala de Dimensões de Personalidade de Marca validada para o contexto brasileiro é composta por 28 itens, avaliados por escala de concordância de dez pontos que variam entre 1 (essa característica não descreve em nada a marca) e 10 (essa característica descreve totalmente a marca) (MUNIZ; MARCHETTI, 2012).

Para o estudo relacional, serão utilizadas a ERC Luxo, desenvolvida e validada nesta pesquisa e a Escala de Dimensões de Personalidade de Marca, adaptada e validada no Brasil por Muniz e Marchetti (2012).

O questionário, composto pelos dois instrumentos de pesquisa utilizados mais as questões sócio-demográficas para caracterização das amostras, encontra-se no Apêndice C.

\subsubsection{Procedimentos de coleta e análise de dados}

A versão de aplicação da ERC Luxo foi disponibilizada na versão online, via redes sociais e via correio eletrônico. Segundo Malhotra (2012), a captação de visitantes em um site ou de acordo com a divulgação por e-mail entre pessoas é um exemplo de amostragem por conveniência. Cabe ressaltar também as vantagens da coleta online, entre elas a flexibilidade, a economia de tempo e o baixo custo (GONÇALVES, 2008). Assim, será validada e confirmada a versão final da ERC Luxo. Ademais, a fim de atingir a amostra necessária, foi realizada também a coleta presencial pela própria pesquisadora.

Os dados advindos da aplicação dos questionários, compostos pelos instrumentos supracitados, foram transferidos ao programa Statistical Package for Social Sciences (SPSS) e, após a etapa de tratamento de dados, realizou-se a análise de componentes principais e análise fatorial exploratória (AFE) para validar a escala ERC para o mercado de luxo, contemplando o objetivo específico II proposto pelo estudo, de acordo com as recomendações de Hair et al. (2009) e Tabachnick e Fidell (2013). A AFE, segundo os autores, descreve e sumariza dados ao agrupar variáveis que apresentam correlação, sendo uma das mais utilizadas técnicas para validar instrumentos de pesquisa. Foram ainda verificadas a confiabilidade, precisão ou consistência interna da escala (índice alfa de Cronbach), de acordo com os critérios propostos por Nunnally e Bernstein (1994), bem como a qualidade ou validade dos itens que a compõem, conforme critérios indicados por Comrey e Lee (1992), e o total de variância do construto "percepção de relacionamento" que foi por ela explicada para que a escala esteja apta a ser utilizada como ferramenta em estudos diagnósticos e relacionais.

Para a execução dos objetivos específicos IV e V, que consistem em identificar a personalidade atribuída às marcas de moda feminina de luxo mais citadas pelas clientes 
pesquisadas e identificar a percepção que as clientes de marcas de moda feminina de luxo possuem quanto ao seu relacionamento com elas, respectivamente, utilizou-se estatística descritiva com médias, desvios-padrão e distribuição de frequência.

A relação entre as variáveis do estudo foi feita a partir da análise de caminhos (path analysis) por meio da modelagem por equações estruturais, usando o critério da máxima verossimilhança, cuja principal função é a especificação e estimação de modelos de relações lineares entre variáveis (KLINE, 2011). Assim, a modelagem por equações estruturais cumpriu a função de verificar o ajuste do modelo proposto, com a utilização do programa estatístico AMOS.

De acordo com Hair et al. (2009) e Kline (2011), a modelagem por equações estruturais consiste em uma técnica que examina a estrutura de inter-relações expressas em uma série de equações, unindo a regressão múltipla linear com uma ou mais variáveis dependentes à análise fatorial. Pode-se caracterizar por dois componentes básicos, a saber, (1) o modelo estrutural, que consiste em um caminho que relaciona variáveis dependentes com independentes, e contempla o objetivo específico VI, ou seja, verificar o ajuste de um modelo estrutural de medição englobando as duas variáveis pesquisadas e (2) o modelo de mensuração, que permite confirmar o ajuste do modelo exploratório obtido na AFE, o que consiste na realização da validação confirmatória do modelo exploratório de mensuração do relacionamento com marcas de moda feminina de luxo, objetivo específico III do estudo. 


\section{RESULTADOS E DISCUSSÃO}

Neste capítulo, serão apresentados os resultados das etapas qualitativas e quantitativas da pesquisa e suas discussões. Na etapa qualitativa, serão apresentados os resultados e discussões da análise de conteúdo, análise semântica e de juízes conduzidas a fim de desenvolver a ERC Luxo. Na etapa quantitativa, são apresentados os resultados e discussões referentes à validação da ERC Luxo, à realização da validação confirmatória do modelo exploratório de mensuração do relacionamento com marcas de moda feminina de luxo, a identificação da personalidade atribuída às marcas de moda feminina de luxo mais citadas pelas clientes pesquisadas, a identificação da percepção que as clientes de marcas de moda feminina de luxo possuem quanto ao seu relacionamento com elas e, por fim, a verificação do o ajuste de um modelo estrutural de medição englobando as duas variáveis pesquisadas, a saber, percepção de relacionamento e personalidade atribuída à marca, sendo a personalidade de marca preditora da percepção de relacionamento com a marca, contemplando, assim, os objetivos propostos pelo presente estudo.

\subsection{Estudo Qualitativo}

\subsubsection{Análise de Conteúdo}

A análise das 14 entrevistas realizadas na etapa qualitativa foi baseada nos princípios da análise categorial temática proposta por Bardin (2014), onde se sugere que o conteúdo das entrevistas seja classificado em categorias temáticas e frequência. As categorias advindas das análises de conteúdo reúnem grupos de elementos com uma razão comum, surgindo, assim, categorias temáticas (BARDIN, 2013).

Neste estudo, as unidades de registros consistem em relatos e narrações identificados nas entrevistas. No que tange à enumeração dos temas, foi utilizada a regra de frequência, onde cada tema é enumerado de acordo com sua aparição nas entrevistas e todos os elementos foram considerados de igual importância. O Quadro 7 revela os resultados da análise de conteúdo. 
Quadro 7 - Resultado da análise de conteúdo

\begin{tabular}{|c|c|c|c|c|}
\hline CATEGORIA & TEMA & FREQUÊNCIA & $\%$ & VERBALIZAÇÃO \\
\hline \multirow[t]{7}{*}{$\begin{array}{l}\text { Experiência } \\
\text { com a Marca }\end{array}$} & $\begin{array}{l}\text { Atendimento de } \\
\text { excelência }\end{array}$ & 13 & 93 & $\begin{array}{l}\text { "Na Tiffany, tu é tratado como rainha"; } \\
\text { "Comprei no Iguatemi de São Paulo. Fui } \\
\text { extremamente bem atendida. Melhor atendida, } \\
\text { impossível" }\end{array}$ \\
\hline & $\begin{array}{l}\text { Atendimento } \\
\text { personalizado }\end{array}$ & 2 & 14 & $\begin{array}{l}\text { "Há ricos emergentes em diferentes regiões do } \\
\text { país, mas o perfil do cliente diverge muito o } \\
\text { que torna necessária a oferta de personalização } \\
\text { levando em consideração preferências e } \\
\text { necessidades específicas por cidade / loja" }\end{array}$ \\
\hline & $\begin{array}{c}\text { Atitude da equipe de } \\
\text { vendas }\end{array}$ & 8 & 57 & $\begin{array}{l}\text { “As peças não são etiquetadas, tu tens que } \\
\text { perguntar qual é o valor, a pessoa vai consultar } \\
\text { num catálogo gigantesco, ela abre um livro de } \\
\text { couro, pesado na tua frente e cata um } \\
\text { numerozinho pra te dizer um preço que sempre } \\
\text { é exorbitante, então já te passa a expectativa de } \\
\text { que vai te dar uma notícia ruim, tipo, você } \\
\text { quase não pode comprar, e isso te constrange" } \\
\text { "Também não gosto daqueles atendentes que te } \\
\text { olham com aquela cara como se tivessem } \\
\text { fazendo um favor a você, causando um } \\
\text { ambiente de compra hostil" }\end{array}$ \\
\hline & $\begin{array}{l}\text { Superação das } \\
\text { expectativas }\end{array}$ & 3 & 21 & $\begin{array}{l}\text { "Eu estava em dúvida no tamanho do diamante } \\
\text { e pedi pra eles compararem com outro tamanho, } \\
\text { mas aquele outro tamanho só tinha em Boston, } \\
\text { e a gente estava no Havaí, e ela disse que } \\
\text { mandava buscar e foi lá e fez" }\end{array}$ \\
\hline & Vendedor brasileiro & 4 & 29 & $\begin{array}{c}\text { "Ter brasileiros na loja porque brasileiros tem } \\
\text { demanda e necessidades diferentes como } \\
\text { clientes"; "A Chanel de Miami, por exemplo, } \\
\text { tem um brasileiro lá, então sempre que eu vou } \\
\text { eu compro com a mesma pessoa, o atendimento } \\
\text { é super" }\end{array}$ \\
\hline & Vendedor específico & 4 & 29 & $\begin{array}{l}\text { "Eu compro bastante na Daslu ali do shopping } \\
\text { novo que abriu, o JK, e ali sou bem atendida, } \\
\text { mas acho também que é porque eu já conheço a } \\
\text { mulher, aí vou sempre com a mesma, tenho um } \\
\text { relacionamento bom com ela. Ela me manda } \\
\text { whatsapp de vez em quando" }\end{array}$ \\
\hline & Entrega domiciliar & 3 & 21 & $\begin{array}{l}\text { "Eu quis e ela ficou com a bolsa e me entregou } \\
\text { no outro dia no hotel, pra que eu não precisasse } \\
\text { voltar na loja"; "Eu já comprei uma coisa aqui } \\
\text { no Brasil da Louis Vuitton, que foi um case pra } \\
\text { livro de viagem, aqueles livros grandes, } \\
\text { comprei lá na Louis Vuitton de São Paulo e eles } \\
\text { mandaram entregar aqui em casa, um negócio } \\
\text { super pesado, assim, uma caixa pesadona, com } \\
\text { uma cartinha bem linda e tal, surpreendente" }\end{array}$ \\
\hline
\end{tabular}




\begin{tabular}{|c|c|c|c|c|}
\hline & Devolução & 1 & 7 & $\begin{array}{l}\text { "Eu comprei um vestido na Le Lis Blanc e } \\
\text { depois de usar lavei e acabou manchando, a } \\
\text { parte mais clara do vestido acabou ficando } \\
\text { manchada pela parte mais escura. Levei na loja } \\
\text { na mesma hora e contei e a gente ficou } \\
\text { discutindo comigo, perguntando onde que eu } \\
\text { tinha mandado lavar. Tipo, não faz isso, não } \\
\text { fica perguntando onde eu mandei lavar, eu fiz } \\
\text { uma compra grande... não tem que perguntar, } \\
\text { tem que pegar o vestido e devolver o dinheiro, } \\
\text { deixar um crédito, sei lá" }\end{array}$ \\
\hline & Garantias & 4 & 29 & $\begin{array}{l}\text { "É um couro que tem garantia vitalícia, os } \\
\text { metais têm garantia vitalícia... Eu pensei, uma } \\
\text { bolsa com metais tem que ter garantia, porque } \\
\text { eu vou pro Brasil, eu vou morar em Floripa, que } \\
\text { é uma cidade de praia, que tem maresia, eu } \\
\text { preciso saber se é uma bolsa que vai durar" }\end{array}$ \\
\hline & Trocas & 1 & 7 & $\begin{array}{l}\text { "Tem um caso que eu comprei uma bota em } \\
\text { Miami e voltei pro Brasil e a bota estava meio } \\
\text { arranhada, Chanel, tá? Comprei em junho, } \\
\text { voltei e em julho eu fui de novo, só um mês de } \\
\text { diferença, levei a bota e eles não quiseram } \\
\text { trocar. A Chanel tem mesmo essa característica, } \\
\text { mas ai eu falei, argumentei e eles trocaram. Na } \\
\text { verdade, não levei outra bota, acabei } \\
\text { comprando outra coisa e completando o } \\
\text { dinheiro, mas dá pra ver que eles não curtiram } \\
\text { aquilo não" }\end{array}$ \\
\hline \multirow[t]{4}{*}{$\begin{array}{l}\text { Fidelização de } \\
\text { Clientes }\end{array}$} & $\begin{array}{l}\text { Capacidade de } \\
\text { resolver problemas }\end{array}$ & 3 & 21 & $\begin{array}{c}\text { "Quando se trata de um pós-venda por } \\
\text { problemas de qualidade, faz-se necessário } \\
\text { contornar a situação com muita habilidade e } \\
\text { precisão" }\end{array}$ \\
\hline & $\begin{array}{l}\text { Brindes e presentes } \\
\text { (sentir-se mimada) }\end{array}$ & 4 & 29 & $\begin{array}{c}\text { "Acho também que receber um mimo, agenda } \\
\text { todo mundo gosta... agendinha de bolsa assim } \\
\text { baratinha todo mundo gosta, uma toalha, um } \\
\text { leque, qualquer coisinha pequena que marque, } \\
\text { que encanta" }\end{array}$ \\
\hline & $\begin{array}{l}\text { Contato após a } \\
\text { compra }\end{array}$ & 9 & 64 & $\begin{array}{l}\text { O meu anel de noivado o Rodrigo comprou na } \\
\text { Tiffany nos Estados Unidos e eu acho demais, } \\
\text { porque eles mandam certificado depois, entram } \\
\text { em contato pra saber se tu gostou”; "A moça } \\
\text { que vendeu o meu anel de noivado pro } \\
\text { Henrique na Cartier, ela já estava trocando } \\
\text { email com ele antes, depois que a gente noivou } \\
\text { ela mandou email pra ele, pediu foto, pediu pra } \\
\text { gente contar a história e tudo mais. Eles querem } \\
\text { fazer parte da tua vida, entendeu?" } \\
\end{array}$ \\
\hline & $\begin{array}{l}\text { Convites para } \\
\text { eventos }\end{array}$ & 4 & 29 & $\begin{array}{c}\text { "Você entra numa loja dessa tem sempre um } \\
\text { coquetel, um champanhe, tem esse diferencial, } \\
\text { e eles me chamam para coquetéis, a Bobstore } \\
\text { sempre me chama pra coquetel, a Bobo } \\
\text { também" } \\
\text { "As equipes de CRM nos headquarters destas } \\
\text { marcas chegam a criar funções específicas só p/ } \\
\text { o Brasil, como PCR (Private Customer } \\
\text { Relationship Manager). São essas pessoas que } \\
\text { geralmente acompanham os principais clientes } \\
\text { aos desfiles destas marcas em Paris e Milão" }\end{array}$ \\
\hline
\end{tabular}




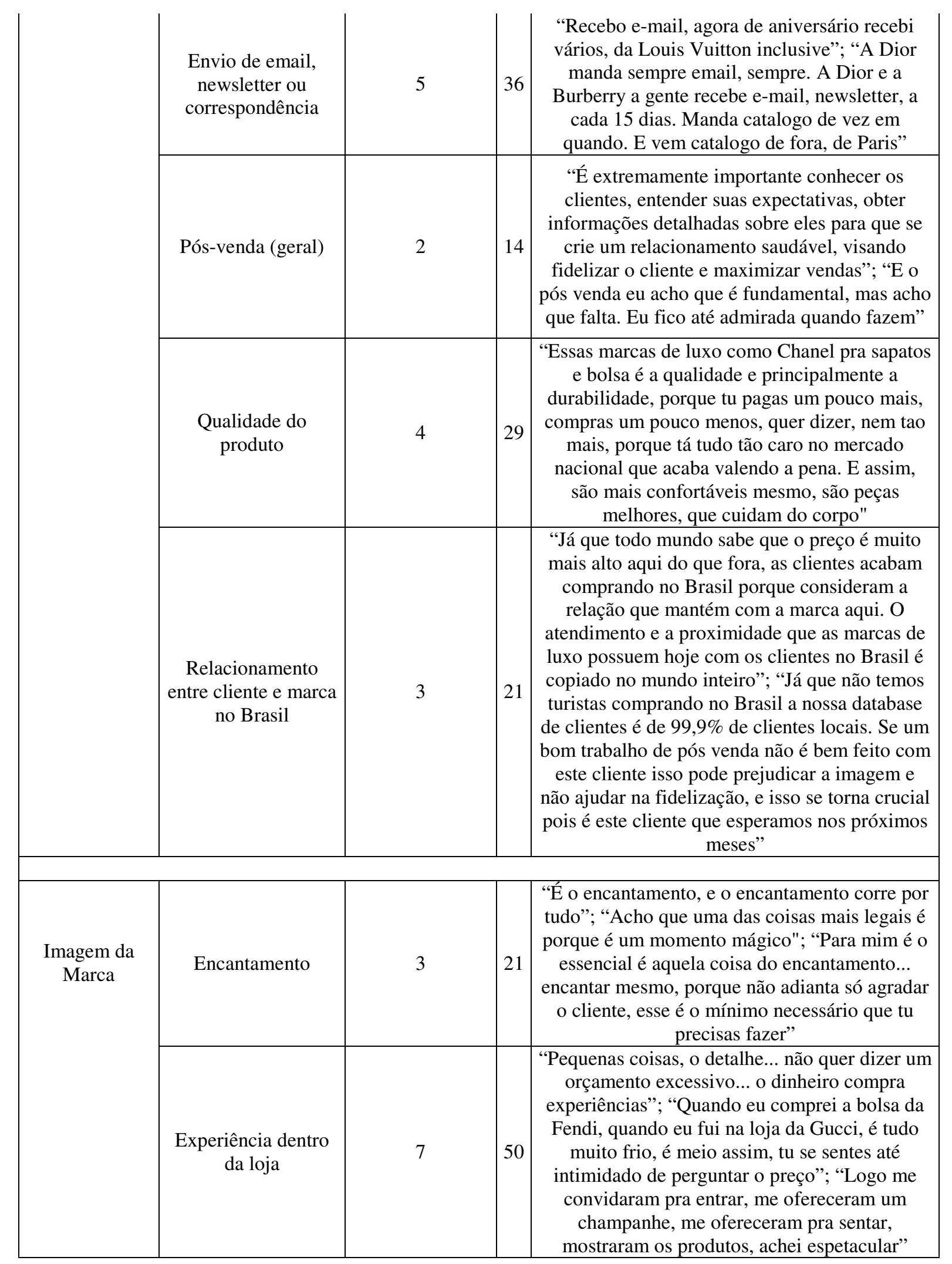




\begin{tabular}{|c|c|c|c|}
\hline $\begin{array}{l}\text { Experimentar os } \\
\text { produtos }\end{array}$ & 4 & 29 & $\begin{array}{l}\text { "Eu acho que a estrutura da loja tem que ser } \\
\text { confortável, o acesso aos produtos, permitir que } \\
\text { você toque neles, porque brasileiro adora tocar, } \\
\text { diferente de lá fora. A gente aponta, elas } \\
\text { perguntam qual quer você quer, aqui não, tem } \\
\text { que trazer, tem que abrir, tem que mostrar"; } \\
\text { "No Japão, não pode tocar nas bolsas, mas no } \\
\text { Brasil a gente lida com o aspecto cultural, então } \\
\text { as nacionalidades trazem diferenças que } \\
\text { precisam ser consideradas no desenvolvimento } \\
\text { do relacionamento com o cliente" }\end{array}$ \\
\hline $\begin{array}{l}\text { Facilidade de } \\
\text { pagamento }\end{array}$ & 4 & 29 & $\begin{array}{l}\text { "As marcas estão fazendo crediário. É uma } \\
\text { coisa meio que de brasileiro com a marca de } \\
\text { luxo. Então você pode comprar uma marca de } \\
\text { luxo parcelada no cartão, e acho que isso que } \\
\text { foi um grande atrativo para as marcas virem pra } \\
\text { cá"; "Apesar de que hoje em dia não tá fazendo } \\
\text { tanta diferença assim, porque aqui você pode } \\
\text { parcelar" }\end{array}$ \\
\hline $\begin{array}{l}\text { Oferta constante de } \\
\text { novidades }\end{array}$ & 3 & 21 & $\begin{array}{l}\text { "As novidades e itens especiais são } \\
\text { fundamentais para atrair a atenção e retenção de } \\
\text { clientes para a marca. Neste caso existe a } \\
\text { necessidade de receber novidades com mais } \\
\text { frequência. Nossos clientes viajam muito e } \\
\text { sempre se queixam de que eles não podem } \\
\text { encontrar os modelos atraentes que eles } \\
\text { costumam ver no exterior"; “Âs vezes antes } \\
\text { mesmo de pensar a funcionalidade, eu penso } \\
\text { sobre a marca em si, agora mesmo to adorando } \\
\text { as bolsas da Prada, está com uma coleção linda, } \\
\text { então vou escolher uma" }\end{array}$ \\
\hline $\begin{array}{l}\text { Personalização dos } \\
\text { produtos }\end{array}$ & 2 & 14 & $\begin{array}{l}\text { "E eu fui na loja da Fendi, e eu tinha comprado } \\
\text { a bolsa em outra loja, mas eu fui na loja da } \\
\text { Fendi porque eu queria gravar as iniciais"; "Aí } \\
\text { eu comprei, ela perguntou se não queria colocar } \\
\text { as iniciais na bolsa, então foi bem diferenciado" }\end{array}$ \\
\hline $\begin{array}{l}\text { Sentimento de } \\
\text { proximidade da } \\
\text { marca }\end{array}$ & 3 & 21 & $\begin{array}{l}\text { "A marca precisa ser de luxo, porém ao mesmo } \\
\text { tempo próxima de mim. A identidade da marca } \\
\text { deve ter a ver com meu estilo de vida, } \\
\text { sentimentos e crenças, ao menos em algum } \\
\text { período específico. Preciso sentir essa } \\
\text { proximidade, seja traduzida no design aplicado } \\
\text { aos produtos, no tom de atendimento na loja, no } \\
\text { e-commerce bem estruturado, na entrega dentro } \\
\text { do prazo, por aî" }\end{array}$ \\
\hline
\end{tabular}

Fonte: elaborado pela autora

Os resultados da análise de conteúdo, análise semântica e de juízes, somados aos itens da Escala de Relacionamento com Clientes (DEMO; ROZZETT, 2013), tiveram por objetivo a elaboração dos itens da versão de aplicação da Escala de Relacionamento com Clientes no mercado de luxo (ERC Luxo). Para tanto, um instrumento piloto, com 46 itens sobre CRM foi disponibilizado para análise semântica e análise de juízes. Este instrumento piloto foi 
composto pelos 14 itens da escada de Demo e Rozzett (2013) e mais 32 itens gerados a partir da análise de conteúdo realizada.

\subsubsection{Análise semântica}

Segundo Pasquali (2012), a análise semântica visa avaliar a clareza dos itens e diminuir quaisquer dúvidas que possam ocorrer no momento em que os sujeitos estiverem respondendo ao questionário. Esta análise contou com a participação de 20 respondentes, todas consumidoras de marcas de moda feminina de luxo, com diferentes idades, cidades e profissões, de modo a obter uma maior variabilidade e representatividade amostral.

A análise semântica resultou na alteração da redação do cabeçalho/introdução da ERC Luxo no questionário, bem como alterou o texto de quatro itens. Ademais, foram inseridos dois itens à escala. A análise semântica não resultou em perda de itens.

\subsubsection{Análise de juízes}

Por fim, a versão de aplicação foi submetida à análise de juízes, onde um grupo composto por oito especialistas na área, dentre mestres e doutores da Universidade de Brasília (UnB), Universidade Federal de Santa Catarina (UFSC) e Universidade Federal do Paraná (UFPR) avaliou os itens com o propósito de verificar a pertinência dos mesmos em relação aos conceitos de CRM. O nível de concordância dos juízes foi de $80 \%$, seguindo as recomentações de Pasquali (2012).

Visto que as análises semântica e de juízes foram realizadas concomitantemente, os oitro especialistas analisaram a versão da ERC Luxo composta por 46 itens. Esta etapa resultou na retirada de oito itens, visto que não houve consenso a respeito deles entre os juízes. Ainda, a redação de seis itens foi alterada, de forma a torná-los mais claros e objetivos.

Por conseguinte, tem-se pronta a versão de aplicação do instrumento Escala de Relacionamento com Clientes no mercado de Luxo - ERC Luxo, com um total de 40 itens, sendo 14 originários da escala de Demo e Rozzett (2013) e 26 advindos das análises qualitativas realizadas. São somados, ainda, os 28 itens da Escala de Dimensões de Personalidade de Marca validada para o contexto brasileiro, propostos por Muniz e Marchetti (2012). A composição final, inclusas as quatro perguntas sóciodemográficas, revela um questionário com 72 itens. Assim, parte-se à etapa quantitativa. 


\subsection{Estudo Quantitativo}

Este capítulo demonstrará os resultados, conforme cada objetivo proposto pela pesquisa.

\subsubsection{Estudo 1: Validação Exploratória da ERC Luxo}

Tendo em vista que o segundo objetivo específico deste trabalho consiste em "validar a escala de relacionamento com clientes de marcas de moda feminina de luxo", cuja versão de aplicação foi gerada na etapa qualitativa anteriormente descrita, investigou-se a validação psicométrica da escala pela análise dos componentes principais e pela análise fatorial exploratória (AFE).

Em primeira instância, a utilização da análise dos componentes principais visou verificar a viabilidade do uso de análise fatorial para a amostra pesquisada, ou fatorabilidade, ao inspecionar a matriz de correlação e o índice de adequação da amostra proposto por Kaiser-Meyer-Olkin (KMO). Os resultados indicaram correlações significativas entre as variáveis e os altos valores das comunalidades constituindo mais uma indicação da fatorabilidade da matriz. Ademais, o cálculo do KMO obteve índice de 0,92, classificado como "maravilhoso", o que corrobora a comunalidade entre as variáveis e a fatorabilidade da matriz, visto que, quanto mais próximo de 1, maior a comunalidade e melhor a fatorabilidade do conjunto (KAISER, 1974).

Para a realização da AFE, seguiu-se as orientações de Fava e Velicer (1996), escolhendo-se um conjunto de fatores cuja quantidade não fosse sub ou superextraída, evitando distorcer resultados de análises posteriores. Assim, os critérios para essa decisão foram os eigenvalues ou autovalores, a porcentagem de variância explicada, o gráfico scree plot e a análise paralela.

O método eigenvalues maiores que 1,0 indicou oito fatores e a variância total explicada maior que 3\% indicou seis fatores. Por sua vez, o gráfico scree plot, que permite a análise visual do gráfico de autovalores, indica o ponto em que a inclinação deixa de ser acentuada para tornar-se quase horizontal (PASQUALI, 2012). Desta forma, o número de fatores a ser extraído foi três, observando-se o ponto de inflexão, conforme ilustra a Figura 2. 
Figura 2 - Gráfico Scree Plot

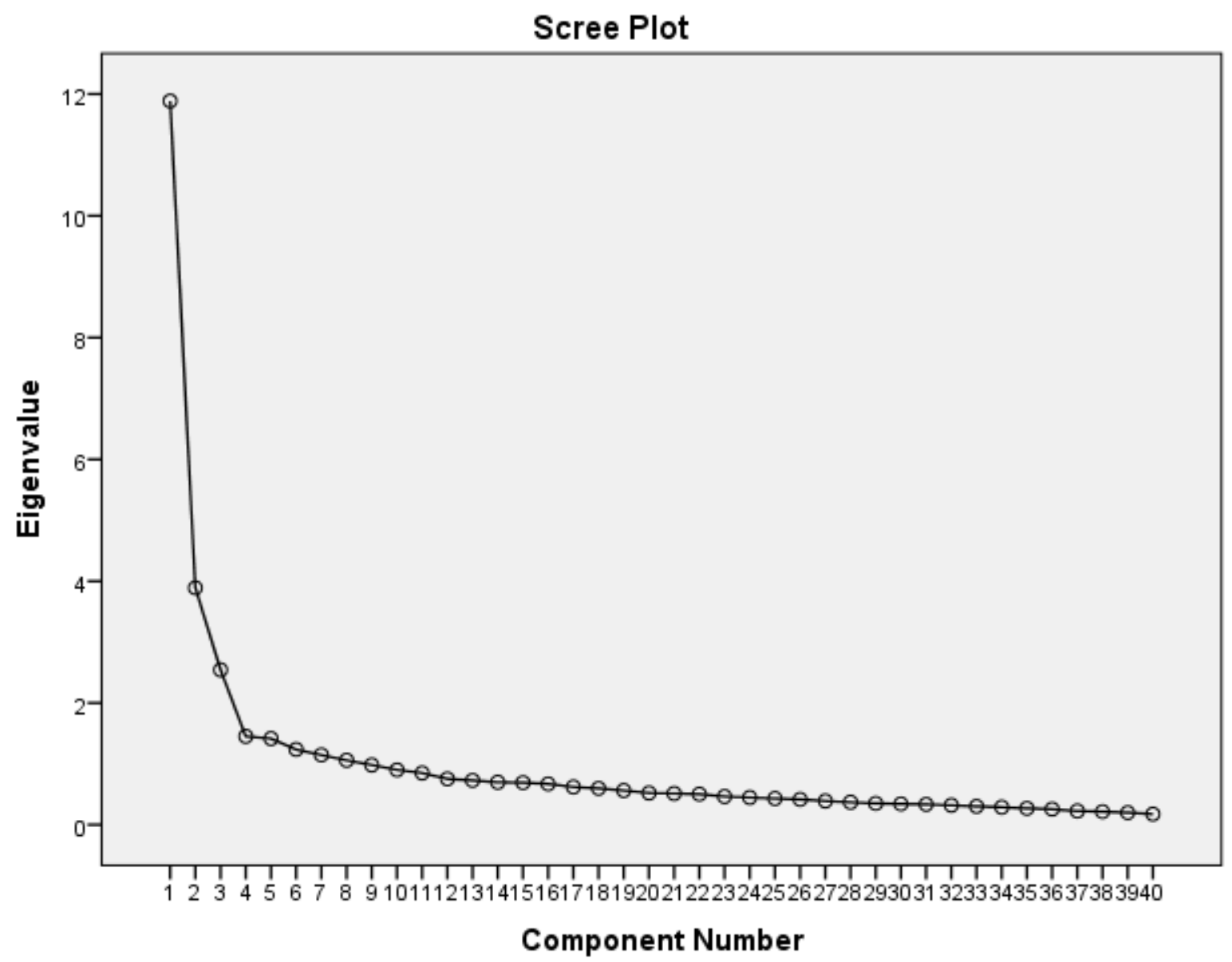

Fonte: Elaborada pela autora

A análise paralela foi utilizada por garantir fidelidade na determinação da quantidade de fatores, de acordo com Hayton, Allen e Scarpello (2004). Ademais, Horn (1965) aponta que a técnica é precisa em $92 \%$ dos casos, possibilitando uma melhor determinação do conjunto de valores a ser extraído.

O valor dos eigenvalues aleatórios foram estimados através do software RanEigen (ENZMANN, 1997). A análise sugeriu, como mais apropriada, a utilização de três fatores, conforme revela a Tabela 6 , considerando que a quantidade de fatores é indicada no momento em que o valor empírico supera o valor estimado (REISE; WALLER; COMREY, 2000). 
Tabela 6 - Resultados da Análise Paralela

\begin{tabular}{c|c|c}
\hline FATOR & $\begin{array}{c}\text { VALOR } \\
\text { ESTIMADO }\end{array}$ & $\begin{array}{c}\text { VALOR } \\
\text { EMPÍRICO }\end{array}$ \\
\hline 1 & 1,766 & 11,886 \\
\hline 2 & 1,671 & 3,89 \\
\hline $\mathbf{3}$ & $\mathbf{1 , 6 0 8}$ & $\mathbf{2 , 5 4 4}$ \\
\hline 4 & 1,549 & 1,452 \\
\hline 5 & 1,504 & 1,415 \\
\hline 6 & 1,46 & 1,236 \\
\hline
\end{tabular}

Fonte: Elaborada pela autora

Posto isto, tem-se que a análise dos componentes principais indicou três fatores, encontrando, ainda, suporte teórico na literatura. Conforme Varva (1993), os componenteschave do marketing de relacionamento ou CRM são qualidade, serviço de atendimento ao cliente e pós-marketing/fidelização de clientes. A partir deste resultado, teve início a análise dos eixos principais, ou análise fatorial, com rotação oblíqua Promax, uma vez que os estudos comportamentais, segundo Pasquali (2012), pressupõem correlações entre as variáveis. Estabeleceu-se, como carga mínima aceitável 0,55, visando reter apenas fatores bons, muito bons e excelentes (COMREY; LEE, 1992).

Na sequência, foram realizados os testes de correlação entre os três fatores. Observouse alta correlação entre os fatores, ilustrada na Tabela 7. A média aritmética da correlação dos três fatores foi 0,45 , acima de 0,3 , o que indica a presença de fator de segunda ordem (PASQUALI, 2012).

Tabela 7 - Matriz de Correlação entre os 3 fatores

\begin{tabular}{c|c|c|c}
\hline FATOR & 1 & 2 & 3 \\
\hline 1 & 1,000 &, 525 &, 332 \\
\hline 2 &, 525 & 1,000 &, 485 \\
\hline 3 &, 332 &, 485 & 1,000 \\
\hline
\end{tabular}

Fonte: Elaborada pela autora

Destarte, os três fatores extraídos foram redimensionados como fatores indicadores latentes de um fator geral de segunda ordem, e uma nova análise de componentes principais foi realizada, revelando um fator, seguida de outra análise, rodada com apenas um fator. 
Como resultado, a escala obteve três fatores de primeira ordem, em que o Fator 1 foi denominado Experiência com a Marca; o Fator 2, Fidelização de Clientes; e o Fator 3, que recebeu o nome de Imagem da Marca. Cabe salientar que tais resultados corroboram a análise de conteúdo realizada para o cumprimento do objetivo específico I, além de encontrarem suporte teórico na literatura. O fator Fidelização de Clientes corresponde ao fator pósmarketing de Vavra (1993); o fator Experiência com a Marca remete, no contexto do mercado de luxo, ao componente serviços de atendimento ao cliente; e, por fim, o fator Imagem da Marca, que traduz as percepções relativas à sofisticação e ao requinte das lojas, localizações e ambientes, o que remete à qualidade e credibilidade da marca no mercado.

No que tange ao fator de segunda ordem, este foi denominado Relacionamento com Clientes, e é formado pelos três fatores de primeira ordem supracitados.

A Tabela 8 demonstra o conteúdo avaliado pelos fatores e suas cargas fatoriais. Observa-se que o fator Fidelização de Clientes pode ser considerado o melhor representante ou elemento mais central para o construto relacionamento com clientes, com carga fatorial de 0,83. O fator Imagem da Marca apresentou carga fatorial de 0,74 , enquanto o fator Experiência com a Marca revelou 0,74.

Tabela 8 - Conteúdo avaliado pelos fatores de primeira ordem em suas cargas fatoriais

\begin{tabular}{c|c|c}
\hline FATOR & CONTEÚDO & CARGA \\
\hline 1 & Experiência com a Marca & 0,74 \\
\hline 2 & Fidelização de Clientes & 0,83 \\
\hline 3 & Imagem da Marca & 0,74 \\
\hline
\end{tabular}

Fonte: Elaborada pela autora

A Figura 3 traz uma representação visual da estrutura fatorial obtida, onde o fator de segunda ordem, relacionamento com o cliente, explica a variância comum dos fatores de primeira ordem. 
Figura 3 - Representação da estrutura fatorial obtida

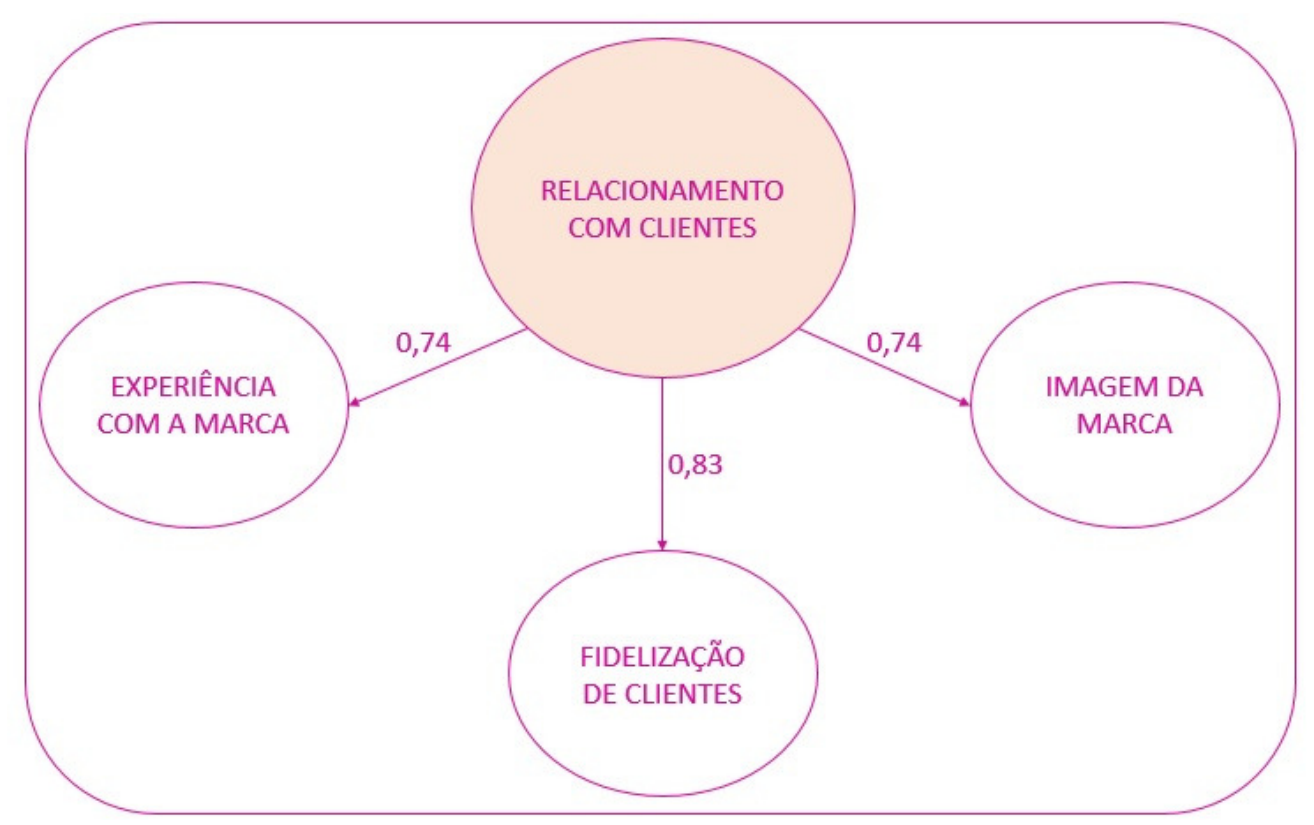

Fonte: Elaborada pela autora

A partir de análises fatoriais hierárquicas, torna-se possível identificar a presença de fatores de segunda ordem, o que contribui à compreensão da estrutura fatorial das escalas, possibilitando, ainda, o desenvolvimento teórico dos campos investigados ao oferecer subsídios adicionais sobre os elementos constitutivos centrais e periféricos dos construtos estudados (LAROS; PUENTE-PALÁCIOS, 2004).

A etapa seguinte avaliou os índices psicométricos da escala, onde os itens da escala foram testados em relação a sua validade ou qualidade dos itens, confiabilidade e variância total explicada (HAIR et al., 2009).

A validade da escala foi analisada por meio da verificação das cargas fatoriais de seus itens, identificando, ainda, a correlação do item com o seu fator (FIELD, 2009). Visto que foi estabelecido como carga mínima 0,55, Comrey e Lee (1992) avaliam que as cargas com valor entre 0,55 e 0,62 são classificadas como boas; entre 0,63 e 0,70 são consideradas muito boas; e superior a 0,71 são consideradas excelentes.

Desta forma, a versão final da solução de primeira ordem da ERC Luxo resultou em um instrumento composto por 23 itens, sendo 10 excelentes, 2 muito bons e 11 bons. Ademais, Pasquali (2012) defende que um construto, para ser bem representado, necessita de cerca de 20 itens. 
O grau de confiabilidade da escala foi calculado por meio do indicador alfa de Cronbach e resultou em bons indicadores, a saber, 0,89 para o Fator 1 de Atendimento e Experiência; 0,84 para o Fator 2 de Fidelização de Clientes; e 0,74 para o Fator 3 de Imagem da Marca. Neste sentido, Cortina (1993) assegura que o alfa é um bom parâmetro de confiabilidade, precisão ou consistência interna da escala, porém, perde sua utilidade em escalas compostas por mais de 40 itens, o que não foi o caso deste estudo. Os resultados acima de 0,70 são considerados confiáveis e acima de 0,80 muito confiáveis (NUNNALLY; BERSTEIN, 1994).

A Tabela 9 apresenta os coeficientes alfa $(\alpha)$ e o número de itens para os fatores extraídos.

Tabela 9 - Coeficientes alfa $(\alpha)$ e o número de itens para os fatores extraídos

\begin{tabular}{c|c|c}
\hline & COEFICIENTE & NÚMERO DE ITENS \\
\hline EATOR & $\alpha$ & 9 \\
\hline FIDELIZAÇÃO & 0,89 & 8 \\
\hline IMAGEM DA MARCA & 0,84 & 6 \\
\hline
\end{tabular}

Fonte: Elaborada pela autora

Ademais, os fatores de primeira ordem explicaram 45,8\% da variância do construto. De acordo com Hair et al. (2009), variâncias explicadas em torno de 50\% representam boas soluções fatoriais. Por fim, a Tabela 10 apresenta os índices psicométricos da ERC Luxo. 
Tabela 10 - Índices psicométricos da versão completa da ERC Luxo

\begin{tabular}{|c|c|c|c|c|}
\hline \multirow[t]{2}{*}{ DESCRIÇÃO DO ITEM } & \multicolumn{3}{|c|}{$\begin{array}{c}\text { CARGA } \\
\text { FATORIAL }\end{array}$} & \multirow[t]{2}{*}{ QUALIDADE } \\
\hline & 1 & 2 & 3 & \\
\hline $\begin{array}{l}32 \text { - Esta marca procura conhecer minha opinião a } \\
\text { respeito dos produtos adquiridos. }\end{array}$ &, 839 & & & Excelente \\
\hline $\begin{array}{l}36 \text { - Esta marca se faz presente em momentos } \\
\text { importantes da minha vida (ex: mensagens de } \\
\text { parabéns, descontos ou presentes no mês ou dia do } \\
\text { aniversário) }\end{array}$ & ,787 & & & Excelente \\
\hline 14 - Esta marca me convida para eventos. & ,758 & & & Excelente \\
\hline $\begin{array}{l}31 \text { - Esta marca me oferece brindes, presentes e/ou } \\
\text { cortesias. }\end{array}$ & ,738 & & & Excelente \\
\hline $\begin{array}{l}30 \text { - Esta marca utiliza meu canal de comunicação } \\
\text { preferido (ex: telefone, correspondência, e-mail, } \\
\text { mensagens via celular) para se comunicar comigo. }\end{array}$ & ,721 & & & Excelente \\
\hline $\begin{array}{l}33 \text { - Esta marca me oferece atendimento } \\
\text { personalizado/exclusivo. }\end{array}$ & ,690 & & & Muito bom \\
\hline $\begin{array}{l}8 \text { - Esta marca procura conhecer minhas } \\
\text { preferências. }\end{array}$ & ,610 & & & Bom \\
\hline $\begin{array}{l}29 \text { - Eu sou atendida, nas lojas desta marca, pelo (a) } \\
\text { vendedor (a) da minha preferência. }\end{array}$ & ,608 & & & Bom \\
\hline $\begin{array}{l}38 \text { - Esta marca me oferece atendimento ou serviços } \\
\text { de entrega domiciliar, caso solicitados. }\end{array}$ &, 558 & & & Bom \\
\hline 5 - Eu me identifico com esta marca. & & 809 & & Excelente \\
\hline $\begin{array}{l}10 \text { - Estou disposta a comprar outros produtos desta } \\
\text { marca. }\end{array}$ & & ,724 & & Excelente \\
\hline 2 - Eu recomendo esta marca a amigos e familiares. & &, 716 & & Excelente \\
\hline 1 - Esta marca merece minha confiança. & & 617 & & Bom \\
\hline $\begin{array}{l}4 \text { - Minhas experiências de compra com esta marca } \\
\text { superam minhas expectativas. }\end{array}$ & &, 587 & & Bom \\
\hline $\begin{array}{l}7 \text { - Os preços dos produtos desta marca são justos } \\
\text { (relação custo/benefício). }\end{array}$ & &, 573 & & Bom \\
\hline 6 - Esta marca me trata com respeito. & &, 570 & & Bom \\
\hline $\begin{array}{l}12 \text { - Os produtos vendidos por esta marca têm } \\
\text { qualidade. }\end{array}$ & &, 554 & & Bom \\
\hline $\begin{array}{l}23 \text { - Os ambientes das lojas desta marca são } \\
\text { sofisticados. }\end{array}$ & & & ,816 & Excelente \\
\hline $\begin{array}{l}19 \text { - Esta marca é reconhecida no mercado como } \\
\text { uma marca de luxo. }\end{array}$ & & & ,733 & Excelente \\
\hline
\end{tabular}


22 - As lojas desta marca estão localizadas em endereços e/ou bairros nobres.

\begin{tabular}{|c|c|c|c|c|}
\hline $\begin{array}{l}24 \text { - A publicidade realizada por essa marca condiz } \\
\text { com o que ela realmente oferece. }\end{array}$ & & &, 584 & Bom \\
\hline $\begin{array}{l}40 \text { - Os produtos desta marca dão prestígio a quem } \\
\text { os usa. }\end{array}$ & & & ,569 & Bom \\
\hline 20 - Esta marca tem credibilidade no mercado. & & & ,558 & Bom \\
\hline Confiabilidade & 0,89 & 0,84 & 0,74 & \\
\hline
\end{tabular}

Fonte: Elaborada pela autora

Além da análise de indicadores psicométricos, é importante que os itens encontrem amparo teórico na literatura. Observa-se que os conjuntos de itens que compõem os três fatores revelaram conteúdo teórico pertinente ao construto abordado, visto que Vavra (1993) aponta que o marketing de relacionamento é formado por três componentes, quais sejam, qualidade, serviços de atendimento e fidelização de clientes.

O fator 1 representa o construto teórico 'experiência com a marca', que engloba aspectos de qualidade do relacionamento (AA; BLOEMER; HENSELER, 2013) e o atendimento aos clientes, por meio das interações entre todos os funcionários e representantes da marca e os clientes (GRÖNROOS, 2009). Já o fator 2 representa o construto teórico ‘fidelização de clientes', uma vez que compreende as estratégias de pós-marketing, relativas à retenção de clientes, por meio de programas e ações que promovam a lealdade deles (DEMO; ROZZETT, 2013; VAVRA, 1993). Por fim, o fator 3 representa o construto teórico 'imagem da marca', visto que explicita as percepções do mercado em relação à marca, compreendendo a imagem e a credibilidade da organização e a qualidade de produtos e serviços associados à marca (BIEL, 1993; KELLER, 2012). A seguir, o Quadro 8 apresenta os itens da ERC Luxo e sua aderência à literatura visitada. 
Quadro 8 - Validade de Conteúdo da ERC Luxo

\begin{tabular}{|c|c|c|}
\hline FATOR & DESCRIÇÃO DO ITEM & SUPORTE TEÓRICO \\
\hline \multirow{9}{*}{ 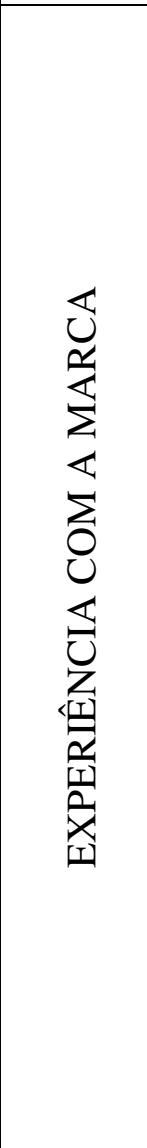 } & $\begin{array}{l}32 \text { - Esta marca procura conhecer minha } \\
\text { opinião a respeito dos produtos adquiridos. }\end{array}$ & $\begin{array}{c}\text { Hoffman (2000), Grönroos (2009), } \\
\text { Demo e Pêssoa (2015) }\end{array}$ \\
\hline & $\begin{array}{l}36 \text { - Esta marca se faz presente em momentos } \\
\text { importantes da minha vida (ex: mensagens de } \\
\text { parabéns, descontos ou presentes no mês ou dia } \\
\text { do aniversário) }\end{array}$ & Vavra (1993), Huang (2015) \\
\hline & 14 - Esta marca me convida para eventos. & Vavra (1993) \\
\hline & $\begin{array}{l}31 \text { - Esta marca me oferece brindes, presentes } \\
\text { e/ou cortesias. }\end{array}$ & Huang (2015) \\
\hline & $\begin{array}{l}30 \text { - Esta marca utiliza meu canal de } \\
\text { comunicação preferido (ex: telefone, } \\
\text { correspondência, e-mail, mensagens via } \\
\text { celular) para se comunicar comigo. }\end{array}$ & $\begin{array}{l}\text { Payne (2006), Lee e Jun (2007), } \\
\text { Demo e Pessôa (2015) }\end{array}$ \\
\hline & $\begin{array}{l}33 \text { - Esta marca me oferece atendimento } \\
\text { personalizado/exclusivo. }\end{array}$ & $\begin{array}{c}\text { Sheth e Parvatiyar (2002), Payne } \\
\text { (2006), Huang (2015) }\end{array}$ \\
\hline & $\begin{array}{l}8 \text { - Esta marca procura conhecer minhas } \\
\text { preferências. }\end{array}$ & $\begin{array}{l}\text { Berry e Gresham (1986), Hoffman } \\
\text { (2000) }\end{array}$ \\
\hline & $\begin{array}{l}29 \text { - Eu sou atendida, nas lojas desta marca, } \\
\text { pelo (a) vendedor (a) da minha preferência. }\end{array}$ & $\begin{array}{c}\text { D'Angelo, Schneider e Larán (2006), } \\
\text { Milan e De Toni (2012), Huang } \\
\text { (2015) }\end{array}$ \\
\hline & $\begin{array}{l}38 \text { - Esta marca me oferece atendimento ou } \\
\text { serviços de entrega domiciliar, caso solicitados. }\end{array}$ & $\begin{array}{c}\text { Mohammadhossein e Zakaria (2012) } \\
\text { Dave e Dhamija (2013) }\end{array}$ \\
\hline \multirow{8}{*}{ 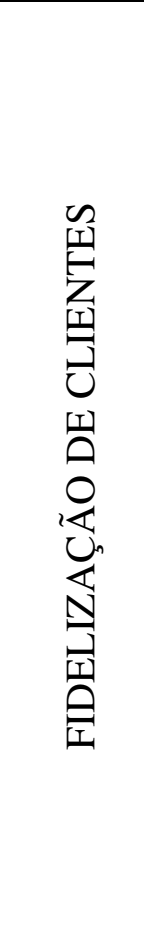 } & 5 - Eu me identifico com esta marca. & Fournier (1998), McKenna (1999) \\
\hline & $\begin{array}{l}10 \text { - Estou disposta a comprar outros produtos } \\
\text { desta marca. }\end{array}$ & $\begin{array}{c}\text { Reichheld (1996), Sheth e Parvatiyar } \\
\text { (2002) }\end{array}$ \\
\hline & $\begin{array}{l}2 \text { - Eu recomendo esta marca a amigos e } \\
\text { familiares. }\end{array}$ & $\begin{array}{c}\text { Reichheld (1996), Morgan e Hunt } \\
\text { (1994) }\end{array}$ \\
\hline & 1 - Esta marca merece minha confiança. & $\begin{array}{l}\text { Vavra (1993), Payne (2006), Kotler e } \\
\text { Keller (2012), Demo e Rozzett } \\
\text { (2013) }\end{array}$ \\
\hline & $\begin{array}{l}4 \text { - Minhas experiências de compra com esta } \\
\text { marca superam minhas expectativas. }\end{array}$ & $\begin{array}{c}\text { Grönroos (2009), Kotler e Keller } \\
\text { (2012), Steel, Dubelaar e Ewing } \\
\text { (2013) }\end{array}$ \\
\hline & $\begin{array}{l}7 \text { - Os preços dos produtos desta marca são } \\
\text { justos (relação custo/benefício). }\end{array}$ & $\begin{array}{c}\text { Sheth e Parvatiyar (2002), Grönroos } \\
\text { (2009) }\end{array}$ \\
\hline & 6 - Esta marca me trata com respeito. & $\begin{array}{c}\text { McKeena (1999), Sheth e Parvatiyar } \\
\text { (2002) }\end{array}$ \\
\hline & $\begin{array}{l}12 \text { - Os produtos vendidos por esta marca têm } \\
\text { qualidade. }\end{array}$ & $\begin{array}{c}\text { Sheth e Parvatiyar (2002), Grönroos } \\
\text { (2009) }\end{array}$ \\
\hline
\end{tabular}




\begin{tabular}{|c|c|c|}
\hline \multirow{6}{*}{ 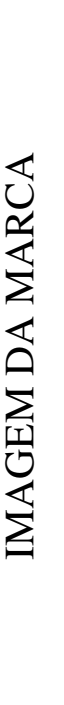 } & $\begin{array}{l}23 \text { - Os ambientes das lojas desta marca são } \\
\text { sofisticados. }\end{array}$ & $\begin{array}{c}\text { Braga (2004), Castarède (2005), De } \\
\text { Sá e Marcondes (2010), Kim e Sung } \\
\text { (2013) }\end{array}$ \\
\hline & $\begin{array}{l}19 \text { - Esta marca é reconhecida no mercado } \\
\text { como uma marca de luxo. }\end{array}$ & $\begin{array}{l}\text { Braga (2004), Castarède (2005), } \\
\text { S'Angelo (2006) }\end{array}$ \\
\hline & $\begin{array}{l}22 \text { - As lojas desta marca estão localizadas em } \\
\text { endereços e/ou bairros nobres. }\end{array}$ & $\begin{array}{l}\text { Dubois, Czellar e Laurent (2010), } \\
\text { Kim e Sung (2013) }\end{array}$ \\
\hline & $\begin{array}{l}24 \text { - A publicidade realizada por essa marca } \\
\text { condiz com o que ela realmente oferece. }\end{array}$ & $\begin{array}{l}\text { Vavra (1993), Morgan e Hunt } \\
\text { (1994), Grönroos (2009) }\end{array}$ \\
\hline & $\begin{array}{l}40 \text { - Os produtos desta marca dão prestígio a } \\
\text { quem os usa. }\end{array}$ & $\begin{array}{l}\text { Allères (2006), Dubois, Czellar e } \\
\text { Laurent (2010), Diniz (2012) }\end{array}$ \\
\hline & 20 - Esta marca tem credibilidade no mercado. & $\begin{array}{l}\text { Vavra (1993), McKenna (1999), } \\
\text { Malar et al. }(2012)\end{array}$ \\
\hline
\end{tabular}

Fonte: Elaborado pela autora

\subsubsection{Estudo 2: Validação Confirmatória da ERC Luxo}

Visando cumprir o objetivo específico III, 'realizar a validação confirmatória do modelo exploratório de mensuração do relacionamento com marcas de moda feminina de luxo obtido no objetivo II', partiu-se à análise fatorial confirmatória, por meio da modelagem por equações estruturais (MEE), método de estimação da verossimilhança, uma vez que é o método de estimação mais usado em MEE por ser mais robusto a problemas de normalidade, além de ser eficaz tanto para amostras pequenas quanto para amostras grandes, entre $150 \mathrm{e}$ 400 sujeitos (HAIR et al., 2009).

A análise por meio da MEE envolve o teste da teoria de mensuração - como os construtos são representados, e a teoria estrutural - como os construtos se relacionam entre si (HAIR et al., 2009).

Posto isto, índices de ajuste são utilizados para estabelecer a aceitabilidade de um modelo MEE. Contudo, o pesquisador deve usar um índice incremental e um índice absoluto, além do valor do qui-quadrado e dos graus de liberdade associados. Um modelo que relata o valor $\chi 2$ normado (NC, ou CMIN/df, onde CMIN é a estatística do $\chi 2$ e df são os graus de liberdade do modelo), CFM (Comparative Fit Index ou índice de ajuste comparativo) e RMSEA (raiz do erro médio quadrático de aproximação) disporá de suficiente informação para sua avaliação (HAIR et al., 2009).

Assim, conforme Kline (2011), a verificação do ajuste global de um modelo à amostra pesquisada pode ser realizada por meio de um indicador de ajuste absoluto, que utiliza a estatística de teste qui-quadrado (NC) e pela estatística RMSEA, que também é um índice de 
má qualidade do ajuste (valores maiores indicam ajustes pobres) e que representa melhor quão bem um modelo se ajusta a uma população e não apenas a uma amostra usada para estimação; e, por fim, por um indicador de ajuste incremental, como o CFI que, por ser mais insensível à complexidade dos modelos, está entre os índices mais usados (HAIR et al., 2009).

Kline (2011) orienta, ainda, que para que os valores sejam satisfatórios para um modelo estrutural, eles devem obedecer aos seguintes critérios: valores para NC (CMIN/DF) de 2,0 ou 3,0 e no máximo até 5,0; valores para CFI iguais ou superiores a 0,90; e valores para RMSEA inferiores a 0,05 ou até 0,10 .

Durante a confirmação da estrutura obtida na análise fatorial exploratória, os itens 7,8 e 24 apresentaram baixas cargas, sendo então retirados do modelo, pois não contribuíam para a explicação do construto. Desta forma, a estrutura final da ERC Luxo abrange 20 itens, corroborando que este é o número ideal para um construto ser bem representado (PASQUALI, 2012). Ressalta-se, ainda, que a solução fatorial de três fatores foi mantida, sendo os 20 itens da escala distribuídos nos mesmos três fatores obtidos na análise exploratória.

Com o propósito de verificar as dimensões da escala, os modelos unifatorial e multifatorial foram testados e comparados, seguindo as recomendações de parcimônia de Byrne (2013). O modelo unifatorial apresentou índices piores ( $\mathrm{NC}=6,18 ; \mathrm{CFI}=0,61$; RMSEA=0,13) quando comparado ao modelo multifatorial de três fatores $(\mathrm{NC}=2,31$; $\mathrm{CFI}=0,90 ; \mathrm{RMSEA}=0,06$ ). Tais resultados tornam possível afirmar que a escala possui um bom ajuste, uma vez que todos os parâmetros estão dentro das recomendações de Kline (2011). A Tabela 11 apresenta estes índices.

Tabela 11 - Índices de ajuste da análise confirmatória

\begin{tabular}{c|c|c}
\hline PARÂMETROS & $\begin{array}{c}\text { REFERÊNCIA } \\
(\text { KLINE, 2009) }\end{array}$ & ERC LUXO \\
\hline NC $(\chi 2 / \mathrm{df})$ & $<3,0$ & 2,31 \\
\hline CFI & $\geq 0,90$ & 0,90 \\
\hline RMSEA & $<0,08$ & 0,06 \\
\hline
\end{tabular}

Fonte: Elaborada pela autora

Ademais, as cargas fatoriais dos itens da validação confirmatória variaram entre 0,5 e 0,82, revelando boa qualidade e validade da escala (HAIR et al., 2009). 
Ainda, no intento de melhorar o ajuste obtido, os índices de modificação (I.M.) também foram analisados, de acordo com as orientações de Kline (2011). Os I.M. entre as variáveis I22 ('As lojas desta marca estão localizadas em endereços e/ou bairros nobres') e I23 ('Os ambientes das lojas desta marca são sofisticados') foram de 40,93. Desta forma, uma seta dupla foi introduzida entre as variáveis, indicando correlação positiva entre os itens, sendo que há, efetivamente, amparo teórico para esta associação. Para Tungate (2009), a atmosfera luxuosa da loja física de uma marca de luxo depende de sua ambientação, formada por diversos fatores, entre eles sua localização, o design e arquitetura da loja e a disposição dos produtos dentro da mesma. Neste contexto, o estudo de Manlow e Nobbs (2012) demonstrou que os principais elementos de uma loja de luxo são a presença em grandes cidades, a localização em áreas nobres ou grandes shoppings, a variedade de produtos, a presença de produtos exclusivos, instalação contemporânea e ambientação capaz de comunicar o estilo sofisticado das marcas.

A Figura 4 apresenta o modelo de mensuração obtido na análise fatorial confirmatória com os respectivos parâmetros.

Figura 4 - Análise fatorial confirmatória

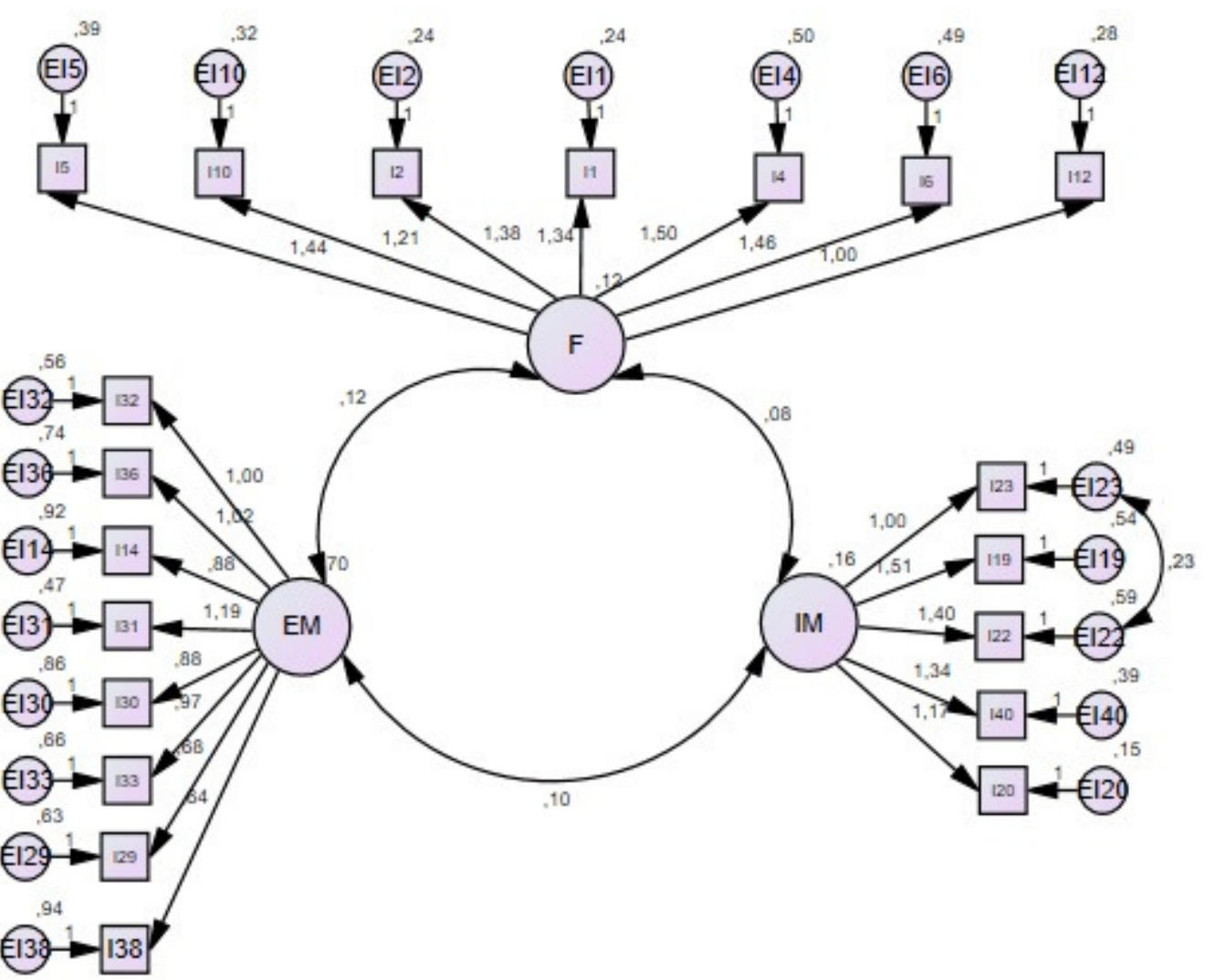

Nota. $\chi 2(166)=382,72 ; \mathrm{p}<0.001 ; \mathrm{NC}=2,31 ; \mathrm{CFI}=0,90 ; \mathrm{RMSEA}=0,06$ 
Fonte: Elaborada pela autora

As análises realizadas permitem concluir que a relação entre clientes e marcas no segmento de moda feminina de luxo é multidimensional, envolvendo três fatores distintos, quais sejam, Experiência com a Marca, Fidelização de Clientes e Imagem da Marca, consistentes com o modelo teórico proposto por Vavra (1993) para marketing de relacionamento ou CRM.

A confiabilidade dos três fatores foi analisada pelo Jöreskog's rho, medida de confiabilidade mais precisa do que o alfa de Cronbach para modelagem por equações estruturais, visto que se baseia em cargas fatoriais e não nas correlações observadas entre as variáveis (CHIN, 1998). O fator Experiência com a Marca obteve $\rho=0,86$; o fator Fidelização de Clientes obteve $\rho=0,81$ e, por fim, o fator Imagem da Marca apresentou $\rho=0,77$. De acordo com Chin (1998), estes valores são considerados bastante satisfatórios, uma vez que os índices Jöreskog's rho devem ser superiores a 0,7.

Na sequência, a validade de construto da ERC Luxo foi testada por meio de validade convergente, validade discriminante e validade nomológica.

Para Hair et al. (2009), a validade convergente refere-se ao grau de concordância entre duas ou mais medidas de um mesmo construto. Neste sentido, o primeiro indício de validade convergente dos fatores de uma escala reside na confiabilidade de cada fator (HAIR et al., 2009); no caso da ERC Luxo, todos acima de 0,7, indicam convergência apropriada. Segundo os autores, uma outra atestação da validade convergente da escala são as cargas fatoriais superiores a 0,5, o que ocorre em todos os 20 itens da ERC Luxo. Com isso, atesta-se que as escala, em suas três dimensões de relacionamento com clientes possui validade convergente.

A validade discriminante indica o grau em que cada medida mensura um construto distinto. Para acessar a validade discriminante, Hair et al. (2009) indicam ser necessário analisar as correlações entre os fatores obtidos no modelo e compará-los com a estimativa da variância extraída para cada dimensão. As evidências de validade discriminante ocorrem quando o valor da variância extraída estimada de cada fator supera o quadrado da correlação entre eles (valores abaixo da diagonal), conforme o critério de Fornell-Larcker (HAIR et al., 2009), o qual diz que um construto latente deve explicar suas medidas de itens melhor do que outro construto. A validade discriminante foi confirmada, como ilustrado na Tabela 12. 
Tabela 12 - Validade discriminante

\begin{tabular}{c|c|c|c}
\hline FATOR & EM & F & IM \\
\hline EM & $0,45^{\mathrm{a}}$ & - & - \\
\hline F & 0,17 & $0,39^{\mathrm{a}}$ & - \\
\hline IM & 0,08 & 0,34 & $0,41^{\mathrm{a}}$ \\
\hline
\end{tabular}

Fonte: Elaborada pela autora

Nota: ${ }^{\text {a }}$ variância extraída

A validade nomológica, por sua vez, demonstra a capacidade de a escala se comportar em relação a outros construtos, conforme indicado pela literatura. Para tanto, faz-se necessário testar se as correlações entre os construtos fazem sentido quando comparadas à teoria (HAIR et al., 2009). Neste sentido, a literatura revela uma expectativa positiva de relação entre as variáveis personalidade de marca e percepção de relacionamento com clientes. Para Fournier (1998), o relacionamento entre marcas e consumidores é mediado pela compatibilidade entre consumidor e marca, compatibilidade esta baseada na atribuição de características humanas às marcas. Neste sentido, Brito (2010) defende que quando as marcas são vistas como detentoras de traços de caráter, o relacionamento entre marcas e clientes tende a ser fortalecido.

Ainda, para o contexto apresentado, a validade nomológica será validada se os valores obtidos na análise de caminhos entre as medidas de personalidade de marca e de relacionamento com clientes forem positivos e significativos. Cabe salientar que a validade nomológica será mostrada no objetivo específico VI, em que se propõe 'verificar o ajuste de um modelo estrutural de medição englobando as duas variáveis pesquisadas, a saber, percepção de relacionamento e personalidade atribuída à marca, sendo a personalidade de marca preditora da percepção de relacionamento com a marca'.

Em síntese, por ora, os resultados revelam que a ERC Luxo possui validade de construto, ou seja, os três fatores Experiência com a Marca, Fidelização de Clientes e Imagem da Marca representam efetivamente o construto relacionamento com clientes e são distintos entre si, constituindo sub-escalas independentes.

5.2.3 Identificação da personalidade atribuída às marcas de moda feminina de luxo

O quarto objetivo desta pesquisa foi 'identificar a personalidade atribuída às marcas de moda feminina de luxo mais citadas pelas clientes pesquisadas'. 
Logo no início do questionário, foi solicitado à respondente que escolhesse livremente uma marca de moda feminina de luxo que seria avaliada. Na sequência, para os próximos 28 itens, a respondente deveria avaliar a marca escolhida segundo o adjetivo apresentado em uma escala tipo Likert de 10 pontos, onde 1 representava 'essa característica não descreve em nada a marca' e 10 representava 'essa característica descreve totalmente a marca'. Os 28 itens da escala dividiam-se em cinco fatores de personalidade de marca. Assim, 8 itens faziam referência ao fator Credibilidade, 7 itens ao fator Alegria, 4 itens ao fator Audácia, 5 itens ao fator Sofisticação e 4 itens ao fator Sensibilidade.

Para efeito de análise da personalidade atribuída às marcas de moda feminina de luxo, foram analisadas as cinco mais citadas entre as 622 participantes do estudo, visto que as demais marcas não tiveram grau de representatividade considerável nos questionários avaliados. São elas, em ordem decrescente de frequência, Zara, Louis Vuitton, Chanel, Michael Kors e Le lis Blanc.

Das cinco dimensões de Personalidade de Marca, obtiveram maiores médias Sofisticação $(x=9,07 ; s=1,11)$, Audácia $(x=8,59 ; s=1,30)$ e Credibilidade $(x=8,02 ; s=1,58)$, sendo estas as principais personalidades atribuídas às marcas de moda feminina de luxo. A Tabela 13 descreve a média, o desvio padrão e a moda encontrados para cada dimensão identificada de personalidade de marca.

Tabela 13 - Média, desvio padrão e moda das variáveis de personalidade atribuídas às marcas de moda feminina de luxo mais citadas

\begin{tabular}{c|c|c|c}
\hline VARIÁVEL & MÉDIA & DESVIO PADRÃO & MODA \\
\hline Credibilidade & 8,02 & 1,58 & 10 \\
\hline Alegria & 7,34 & 1,83 & 10 \\
\hline Audácia & 8,59 & 1,3 & 10 \\
\hline Sofisticação & 9,07 & 1,11 & 10 \\
\hline Sensibilidade & 7,69 & 1,59 & 10 \\
\hline
\end{tabular}

Fonte: Elaborada pela autora

Analisando cada marca de moda feminina de luxo individualmente, torna-se possível identificar a personalidade predominante de cada uma. No Gráfico 25, encontram-se ilustradas as dimensões de personalidade de marca associadas às marcas de moda feminina de luxo mais citadas. A Tabela 14 compila as médias e desvios obtidos para as dimensões de personalidade de marca, de acordo com cada uma das marcas de moda feminina de luxo mais citadas pelas participantes. 
Gráfico 25 - Média das dimensões de Personalidade de Marca para as marcas de moda feminina de luxo mais citadas pelas participantes

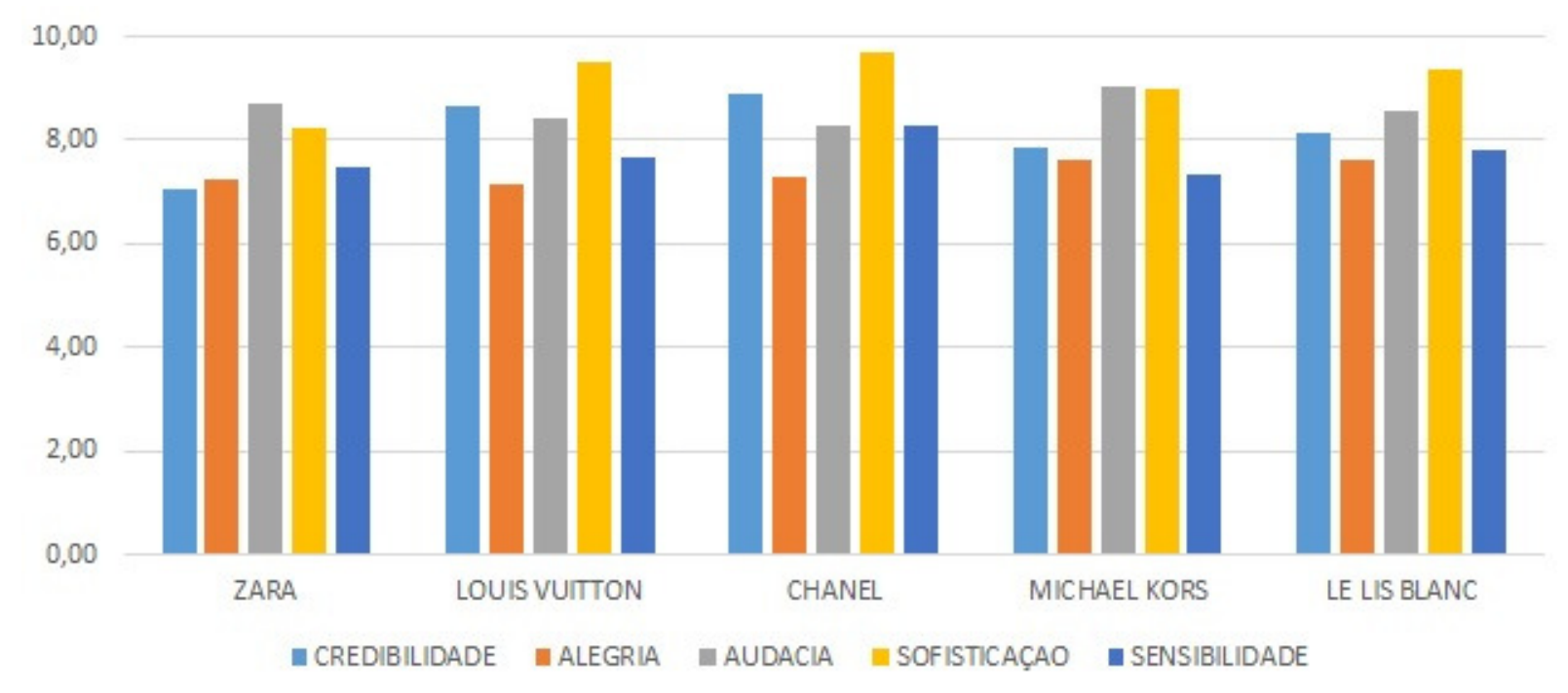

Fonte: Elaborado pela autora

Tabela 14 - Média e desvio padrão das variáveis de personalidade atribuídas às marcas de moda feminina de luxo mais citadas

\begin{tabular}{c|c|c|c|c|c}
\hline MARCA & CREDIBILIDADE & ALEGRIA & AUDACIA & SOFISTICAÇAO & SENSIBILIDADE \\
\hline ZARA & $7,07(1,77)$ & $7,26(1,69)$ & $8,69(1,13)$ & $8,26(1,18)$ & $7,48(1,40)$ \\
\hline LOUIS VUITTON & $8,66(1,27)$ & $7,13(2,24)$ & $8,41(1,30)$ & $9,52(0,69)$ & $7,69(1,61)$ \\
\hline CHANEL & $8,89(1,06)$ & $7,27(1,58)$ & $8,29(1,91)$ & $9,70(0,90)$ & $8,29(1,84)$ \\
\hline MICHAEL KORS & $7,84(1,40)$ & $7,63(1,82)$ & $9,03(0,90)$ & $8,97(1,12)$ & $7,35(1,60)$ \\
\hline LE LIS BLANC & $8,14(1,27)$ & $7,60(1,69)$ & $8,58(1,07)$ & $9,37(0,67)$ & $7,83(1,58)$ \\
\hline
\end{tabular}

Fonte: Elaborada pela autora

Percebe-se que as clientes atribuíram, para as cinco marcas de moda feminina de luxo, a Sofisticação como a principal personalidade de marca, visto que tal característica é fortemente percebida em todas as marcas, com destaque para a marca Chanel, cuja média e desvio padrão revelaram-se 9,70 (0,90). Na sequência, figuram as marcas Louis Vuitton e Le lis Blanc. Sob a perspectiva da sofisticação, De Barnier e Valette-Florence (2013) apontam que a utilização de marcas de luxo está associada a aspectos de prazer, status e simbolismo, onde as marcas são utilizadas para revelar a sofisticação do indivíduo, ajudando-o a projetar uma imagem ao mundo externo. Colocam, ainda, que a aquisição de produtos de luxo serve como meio para o alcance de sofisticação, refinamento e classe. Fritz e Gülow (2013) revelam, ainda, que os consumidores, de forma geral, têm se tornado mais sofisticados devido à ampliação do acesso a produtos premium e de luxo, buscando aquisições que revelem seu 
novo modo de se comportar. Neste sentido, Sthrelau e Freire (2013) assinalam que os produtos de luxo estão associados a marcas capazes de trazer prestígio aos seus consumidores. Por fim, Maehle, Otnes e Supphellen (2011) evidenciam que as marcas percebidas como sofisticadas geralmente são marcas de roupas exclusivas e cujo acesso é restrito a um grupo com maior poder aquisitivo, visto que são tidas como especiais e são marcas com preços elevados.

A segunda dimensão de personalidade de marca mais observada entre as participantes do estudo, para as marcas em análise, foi a audácia, destacando-se a marca Michael Kors com média 9,03 (0,90). Tal dimensão, cujos itens da escala buscam analisar o quão moderna uma marca é percebida, associa-se à autenticidade e originalidade da marca, que integra o ritual de consumo, onde as características associadas à marca irão passar do objeto/marca para o consumidor (STHRELAU; FREIRE, 2013). A autora sugere, ainda, que a exclusividade dos produtos de luxo consiste no primeiro passo para a autenticidade, conceito que abrange a capacidade de ser original e atualizada.

No quesito credibilidade, a marca Chanel destaca-se novamente, revelando-se uma marca com alto nível de credibilidade, com média 8,89 $(1,06)$, seguida pela marca Louis Vuitton, cuja média foi 8,66 (1,27). Para Sthrelau (2013), a credibilidade de uma marca de luxo está associada ao valor da tradição e à consistência da história da marca. Para a autora, o peso da tradição, especialmente para as marcas francesas, no estudo representadas pelas marcas Chanel e Louis Vuitton, apresenta-se como um diferencial competitivo, criando obstáculos a novas marcas, bem como impondo a tradição como um requisito para uma marca ser considerada de luxo. Ainda sobre a credibilidade, a autora defende que os produtos de luxo devem ser produzidos com materiais de alta qualidade e ter boa reputação no mercado.

Os resultados para as dimensões sensibilidade e alegria revelam que tais características, ainda que percebidas pelas clientes, visto que todas as suas médias foram superiores a 7, não configuram as principais características das marcas. Maehle, Otnes e Supphellen (2011) discorrem que as marcas consideradas sensíveis fazem parte da rotina dos indivíduos, utilizadas com maior frequência e associam-se à confiança e lealdade; enquanto as marcas alegres estão associadas ao desejo que os indivíduos têm de serem percebidos como mais divertidos ou alegres aos olhos de seus grupos de referência. Contudo, observando o contexto de luxo, onde sofisticação e exclusividade figuram como atributos fundamentais, a sensibilidade e a alegria não predominam. 
Um ponto que merece atenção é o fato de a marca Zara ter figurado como a marca de moda feminina mais citada pelas participantes do estudo, visto que não se trata de uma marca tradicional do mercado de luxo ou mesmo pertencente a ele (FRITZ; GÜLLOW, 2013). Neste sentido, a literatura assegura que o significado do luxo é específico de uma sociedade, onde uma marca não considerada luxuosa em determinado contexto pode ser avaliada como parte do segmento de luxo em diferente localidade ou, ainda, ter seu conceito alterado devido à passagem do tempo (STHRELAU, 2013).

Bastien e Kapferer (2013) também defendem a percepção do luxo vinculada ao contexto, revelando, ainda, que uma definição abrangente para marca de luxo engloba a marca que vende produtos premium, a preços premium e, mais importante, em ambientes sofisticados e luxuosos, o que se assemelha à situação da marca Zara no contexto brasileiro. Para os autores, a explicação ao fenômeno que considera a Zara uma marca de luxo reside, também, na adoção da empresa às estratégias de luxo, devido ao notório poder de sua inteligência de mercado e aos sofisticados sistemas de informação que permitem responder quase imediatamente aos desejos dos consumidores em todo o mundo. Fritz e Güllow (2013) revelam, ainda, o fenômeno cheap chic, ou barato chique, em que o design, o bom gosto e a diferenciação dos produtos tornam-se os atributos fundamentais aos consumidores. Tais autores apontam, ainda, este fenômeno como uma tendência de mercado, especialmente no setor das marcas de moda.

A relação identificada entre as dimensões de personalidade de marca e o mercado de luxo corrobora a ideia de que a compra de marcas deste segmento configura um processo interativo que envolve branding e identidade de marcas como meios de elevar a visibilidade da marca, reforçar seu posicionamento e orientar estratégias de promoção e publicidade (MANLOW; NOBBS, 2012). Os autores colocam, ainda, que o desenvolvimento destas interações revela, ainda, a interseção entre objetivos comerciais, por parte das empresas, e objetivos pessoais, por meio dos significados atrelados à compra de itens de marcas de luxo. Neste contexto, Riewoldt (2002) aponta que tais marcas preenchem as necessidades de status e de experiências prazerosas dos indivíduos, criando respostas emocionais nos mesmos. Posto isto, os resultados obtidos na presente pesquisa reforçam, a relevância do branding emocional e do consumo hedônico no mercado de luxo.

Como contribuição destes resultados, eles configuram um diagnóstico útil aos gestores de marcas de moda feminina no sentido de direcionar a sua publicidade, reforçando as personalidades identificadas e aprimorando os traços que desejam enfatizar. 
5.2.4 Identificação da Percepção de Relacionamento com marcas de moda feminina de luxo

Como quinto objetivo específico deste trabalho, foi proposto 'identificar a percepção que as clientes de marcas de moda feminina de luxo possuem quanto ao seu relacionamento com elas’. Para cumprir tal objetivo, análises descritivas foram realizadas.

A análise das respostas, levando em consideração cada fator, apontou para o fator 1 (Experiência com a Marca) uma média de 2,78 com desvio padrão de 0,91; para o fator 2 (Fidelização de Clientes) uma média de 4,25 com desvio padrão de 0,54 e, para o fator 3 (Imagem da Marca), média de 4,26 com desvio padrão 0,62.

A variável marketing de relacionamento apresentou média igual a 3,77 e desvio padrão 0,53 , o que permite atribuir ao relacionamento identificado uma percepção positiva, considerando 3 o ponto neutro da escala.

Com exceção do fator Experiência com a Marca, cuja média é de 2,78 e, assim, bastante próxima do ponto neutro da escala, todas as demais médias são superiores a 3 (ponto neutro) e, ainda, próximas de 5, ponto máximo da escala.

Dessa forma, os resultados revelam que os clientes percebem as principais iniciativas de marketing de relacionamento por parte das marcas de moda feminina de luxo das quais são clientes como sendo aquelas relacionadas à fidelização e à imagem da marca. No que tange a média do fator de segunda ordem, o relacionamento com cliente, o resultado obtido permite afirmar que as clientes de marcas de moda feminina de luxo percebem a sua existência. É preciso frisar, contudo, que apesar dos bons resultados, ainda há bastante espaço para melhorias, considerando o ponto máximo da escala (5), especialmente no que se refere às estratégias de experiência com a marca. A Tabela 15 ilustra esses resultados.

Tabela 15 - Visão geral da percepção de relacionamento

\begin{tabular}{c|c|c|c}
\hline TIPO & CONTEÚDO & MÉDIA & DESVIO PADRÃO \\
\hline \multirow{2}{*}{$\begin{array}{c}\text { Primeira } \\
\text { Ordem }\end{array}$} & Experiência com a Marca & 2,78 & 0,91 \\
\cline { 2 - 4 } & Fidelização de Clientes & 4,25 & 0,54 \\
\cline { 2 - 4 } & Imagem da Marca & 4,26 & 0,62 \\
\hline $\begin{array}{c}\text { Segunda } \\
\text { Ordem }\end{array}$ & $\begin{array}{c}\text { Relacionamento com o } \\
\text { cliente }\end{array}$ & 3,77 & 0,53 \\
\hline
\end{tabular}

Fonte: Elaborada pela autora 
As respostas foram avaliadas em relação a cada questão de forma isolada, de maneira a melhorar a visualização dos fatores de primeira ordem. Assim, para destacar as questões positivas e negativas de cada fator de primeira ordem, foi realizada uma avaliação dos itens com base na frequência relativa das respostas obtidas. Utilizou-se a média e a moda como medidas de tendência central, além da análise de distribuição de frequência, haja vista que alguns desvios padrões foram superiores a 1 .

A Tabela 16 apresenta os valores do fator 1 'Experiência com a Marca'.

Tabela 16 - Visão geral da percepção dos clientes a respeito da Experiência com a Marca

\begin{tabular}{l|c|c|c}
\hline \multicolumn{1}{c|}{ DESCRIÇÃO DO ITEM } & MÉDIA & $\begin{array}{c}\text { DESVIO } \\
\text { PADRÃO }\end{array}$ & MODA \\
\hline $\begin{array}{l}\text { P0 - Esta marca utiliza meu canal de } \\
\text { comunicação preferido (ex: telefone, } \\
\text { correspondência, e-mail, mensagens via } \\
\text { celular) para se comunicar comigo. }\end{array}$ & 3,24 & 1,24 & 3 \\
\hline $\begin{array}{l}29 \text { - Eu sou atendida, nas lojas desta marca, } \\
\text { pelo (a) vendedor (a) da minha preferência. }\end{array}$ & 3,11 & 1,08 & 3 \\
\hline $\begin{array}{l}36 \text { - Esta marca se faz presente em momentos } \\
\text { importantes da minha vida (ex: mensagens de } \\
\text { parabéns, descontos ou presentes no mês ou dia } \\
\text { do aniversário) }\end{array}$ & 2,79 & 1,29 & 3 \\
\hline $\begin{array}{l}33 \text { - Esta marca me oferece atendimento } \\
\text { personalizado/exclusivo. }\end{array}$ & 2,76 & 1,24 & 3 \\
\hline $\begin{array}{l}32 \text { - Esta marca procura conhecer minha } \\
\text { opinião a respeito dos produtos adquiridos. }\end{array}$ & 2,73 & 1,23 & 3 \\
\hline $\begin{array}{l}38 \text { - Esta marca me oferece atendimento ou } \\
\text { serviços de entrega domiciliar, caso solicitados. }\end{array}$ & 2,67 & 1,23 & 3 \\
\hline $\begin{array}{l}31 \text { - Esta marca me oferece brindes, presentes } \\
\text { e/ou cortesias. }\end{array}$ & 2,54 & 1,27 & 3 \\
\hline \begin{tabular}{l}
14 - Esta marca me convida para eventos. \\
\hline
\end{tabular}
\end{tabular}

Fonte: Elaborada pela autora

A frequência relativa das respostas do fator 1 de primeira ordem, Experiência com a Marca, é ilustrada pelo Gráfico 26. 
Gráfico 26 - Frequência relativa dos itens do fator Experiência com a Marca

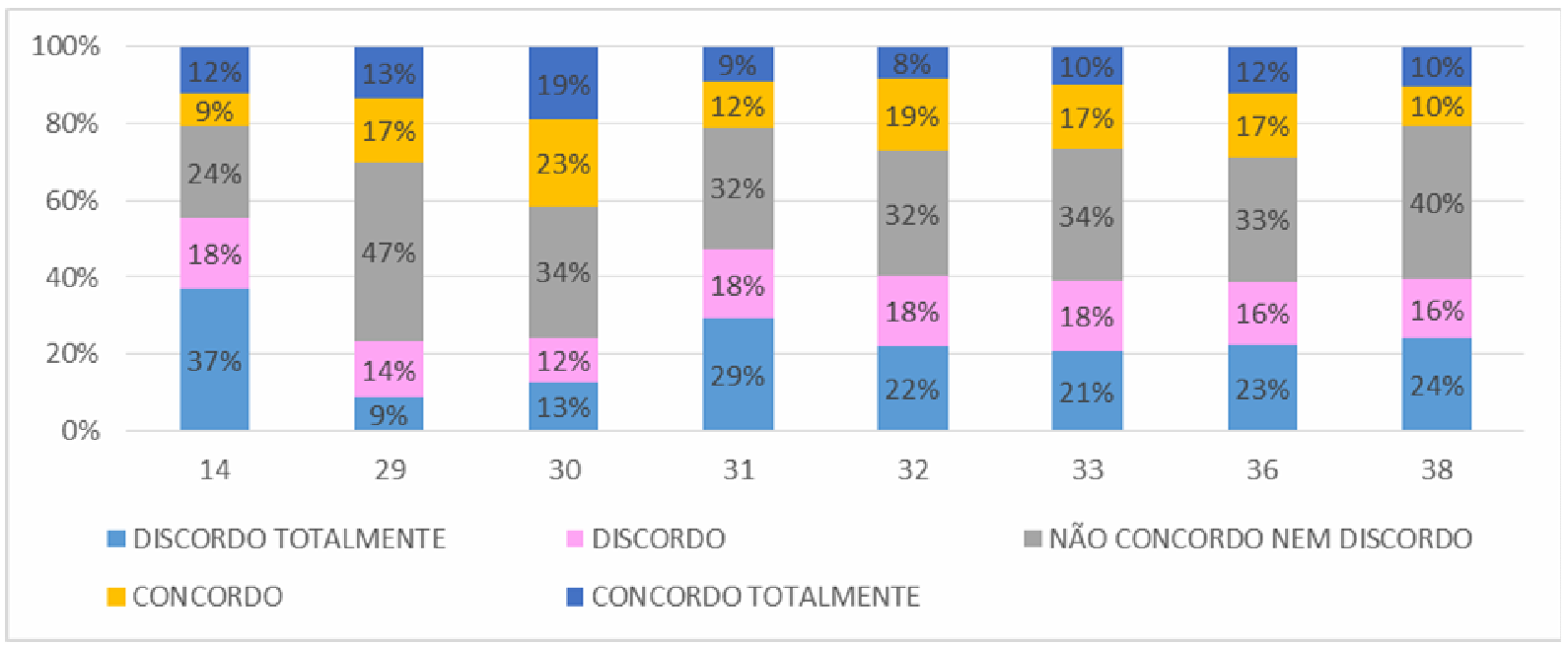

Fonte: Elaborado pela autora

Dos três fatores do construto relacionamento com clientes, o fator 1, Experiência com a Marca foi o que apresentou as menores médias, mostrando-se o aspecto mais vulnerável frente à percepção das clientes pesquisadas e, assim, aquele que mais necessita de atenção por parte dos gestores. Dentro desta perspectiva, a literatura aponta que as experiências com marcas de luxo estão associadas aos aspectos de qualidade do atendimento e níveis de prestação de serviços, que podem ser traduzidos pelo desenvolvimento de uma atmosfera que induza ao sentimento de exclusividade e por meio do treinamento de funcionários que façam com que cada cliente se sinta muito especial (WU; CHEN; CHANEY, 2013).

Como destaques positivos dentro do fator 1 "Experiência com a Marca", encontram-se o item 30 "esta marca utiliza meu canal de comunicação preferido (ex: telefone, correspondência, e-mail, mensagens via celular) para se comunicar comigo", com média 3,24 (DP $=1,24)$ e moda 3; e o item 29 "eu sou atendida, nas lojas desta marca, pelo (a) vendedor (a) da minha preferência", com média 3,11 (DP = 1,08). Por outro lado, os demais itens, ainda que bastante próximos do ponto neutro da escala, configuram pontos críticos, revelando que as clientes não perceberam os esforços das marcas de moda feminina de luxo em relação a conhecer suas preferências, estar presente em suas vidas por meio de mensagens, convites ou atendimento personalizado, tampouco sobre serviços de entrega domiciliar, fatores que constituem um diferencial no atendimento a clientes (MOHAMMADHOSSEIN; ZAKARIA, 2012; DAVE; DHAMIJA, 2013). 
A Tabela 17 apresenta a percepção das clientes quanto ao fator 2, Fidelização de Clientes das marcas de moda feminina de luxo.

Tabela 17 - Visão geral da percepção dos clientes a respeito da Fidelização de Clientes

\begin{tabular}{l|c|c|c}
\hline \multicolumn{1}{c|}{ DESCRIÇÃO DO ITEM } & MÉDIA & $\begin{array}{c}\text { DESVIO } \\
\text { PADRÃO }\end{array}$ & MODA \\
\hline $\begin{array}{l}12 \text { - Os produtos vendidos por esta } \\
\text { marca têm qualidade. }\end{array}$ & 4,58 & 0,59 & 5 \\
\hline $\begin{array}{l}\text { 2 - Eu recomendo esta marca a amigos } \\
\text { e familiares. }\end{array}$ & 4,46 & 0,66 & 5 \\
\hline $\begin{array}{l}10 \text { - Estou disposta a comprar outros } \\
\text { produtos desta marca. }\end{array}$ & 4,41 & 0,72 & 5 \\
\hline $\begin{array}{l}\text { 1 - Esta marca merece minha } \\
\text { confiança. }\end{array}$ & 4,27 & 0,72 & 4 \\
\hline $\begin{array}{l}5 \text { - Eu me identifico com esta marca. } \\
\text { 6 - Esta marca me trata com respeito. }\end{array}$ & 4,21 & 0,79 & 4 \\
\hline $\begin{array}{l}4 \text { - Minhas experiências de compra } \\
\text { com esta marca superam minhas } \\
\text { expectativas. }\end{array}$ & 3,88 & 0,88 & 4 \\
\hline Fon Elabra pela autora & & 0,88 & 4 \\
\hline
\end{tabular}

Fonte: Elaborada pela autora

A frequência relativa das respostas do fator 2 de primeira ordem, Fidelização de Clientes, é ilustrada pelo Gráfico 27.

Gráfico 27 - Frequência relativa dos itens do fator Fidelização de Clientes

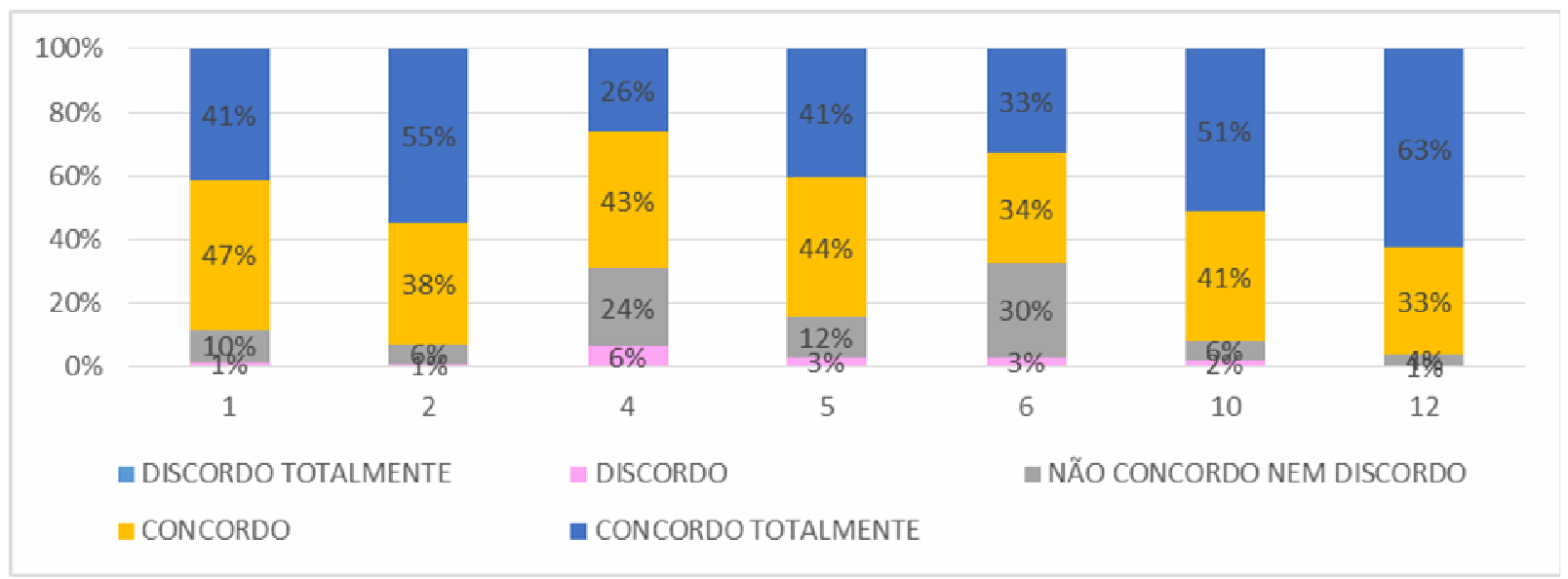

Fonte: Elaborado pela autora

O fator 2, "Fidelização de Clientes", revelou médias acima do ponto neutro (3) para todos os itens, demonstrando que todas as iniciativas voltadas à fidelização das clientes por parte das marcas de moda feminina de luxo são percebidas pelas mesmas. No contexto das 
marcas de luxo, percebe-se a procura por parte dos consumidores por vínculos emocionais, onde a criação de um universo simbólico configura um meio de reforçar a lealdade dos clientes (GODEY; PEDERZOLI; AIELLO; DONVITTO; WIEDMANN; HENNINGS, 2013).

Como destaque positivo está o item 12 "Os produtos vendidos por esta marca têm qualidade", com média 4,58 ( $\mathrm{DP}=0,59)$ e moda 5. Isto revela que a manutenção da qualidade dos produtos tem efeitos positivos na percepção das clientes em relação ao desenvolvimento de lealdade à marca. Sobre isto, Godey et al. (2013) indicam que a percepção de valor de produtos no mercado de luxo apresenta relação positiva e significativa com os atributos do produto, com referência a seus benefícios e utilidades, onde aspectos como qualidade, usabilidade, confiabilidade e durabilidade são essenciais à construção da percepção de valor para este cliente.

Como ponto crítico, encontra-se o item 4 "minhas experiências de compra com esta marca superam minhas expectativas", cuja média é 3,88 (DP $=0,88)$ e moda 4 e que, mesmo sendo a média mais baixa, ainda está acima do ponto neutro, revelando percepções positivas quanto a este aspecto, mas ao se comparar com os outros itens, é o que enseja melhorias. Neste sentido, a literatura aponta que as marcas de luxo oferecem a aquisição de produtos de alta qualidade aliada a benefícios emocionais relacionados a prestígio e exclusividade que geram expectativas nem sempre supridas nos consumidores (WU; CHEN; CHANEY, 2013). Conforme os autores, o gap entre a expectativa dos consumidores e a realidade do serviço entregue está associada às equipes de vendas, que muitas vezes se revelam pouco prestativas e tendem até mesmo a intimidar os clientes.

Por fim, a Tabela 18 mostra a visão geral sobre a percepção das clientes em relação ao fator 3, Imagem da Marca.

Tabela 18 - Visão geral da percepção das clientes a respeito da Imagem da Marca

\begin{tabular}{l|c|c|c}
\hline \multicolumn{1}{c|}{ DESCRIÇÃO DO ITEM } & MÉDIA & $\begin{array}{c}\text { DESVIO } \\
\text { PADRÃO }\end{array}$ & MODA \\
\hline 20 - Esta marca tem credibilidade no mercado. & 4,51 & 0,59 & 5 \\
\hline $\begin{array}{l}23 \text { - Os ambientes das lojas desta marca são } \\
\text { sofisticados. }\end{array}$ & 4,34 & 0,79 & 5 \\
\hline $\begin{array}{l}22 \text { - As lojas desta marca estão localizadas em } \\
\text { endereços e/ou bairros nobres. }\end{array}$ & 4,22 & 0,89 & 5 \\
\hline $\begin{array}{l}\text { 40 - Os produtos desta marca dão prestígio a } \\
\text { quem os usa. }\end{array}$ & 4,2 & 0,82 & 5 \\
\hline
\end{tabular}


19 - Esta marca é reconhecida no mercado como uma marca de luxo.

Fonte: Elaborada pela autora

A frequência relativa das respostas do fator 3 de primeira ordem, Imagem da Marca, é ilustrada pelo Gráfico 28.

Gráfico 28 - Frequência relativa dos itens do fator Imagem da Marca

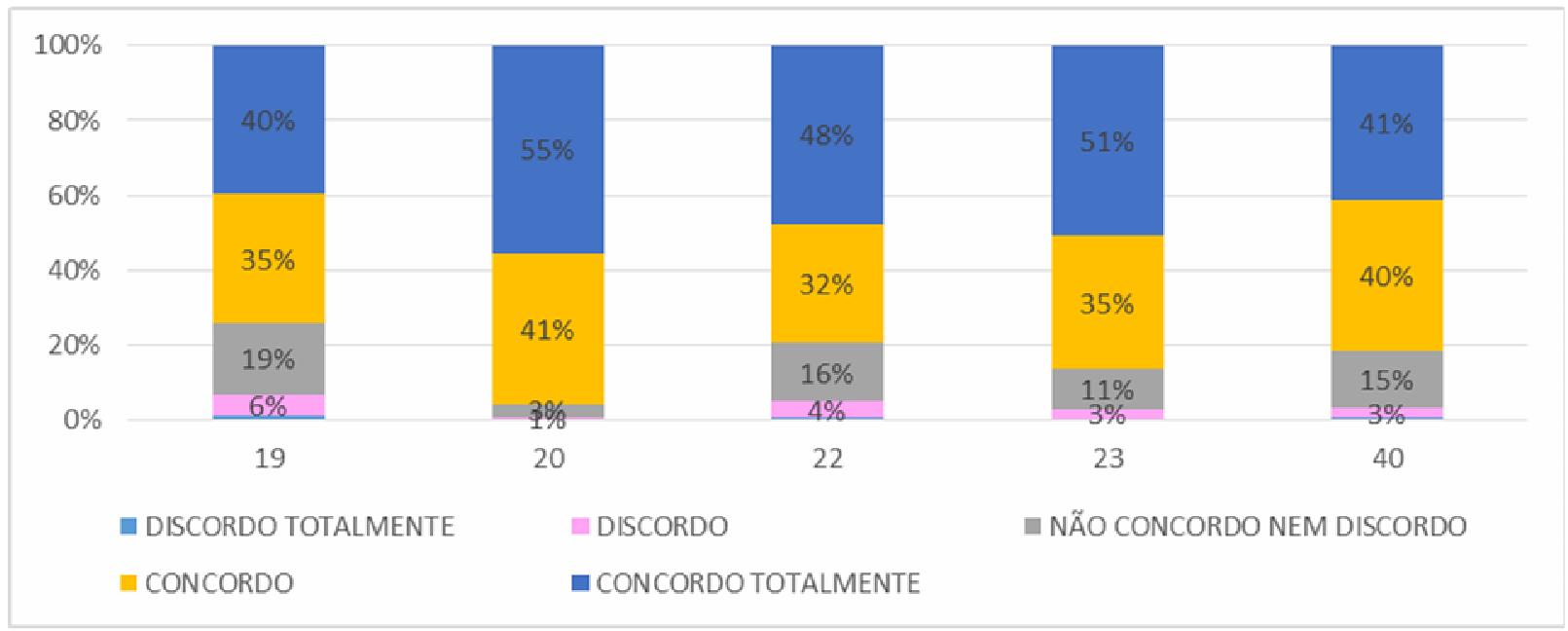

Fonte: Elaborado pela autora

O fator 3 "Imagem da Marca" apresentou excelentes resultados em relação à percepção das clientes dos esforços relacionados das marcas de moda feminina de luxo em relação às suas imagens, isto porque todos os itens apresentaram média superior a 4 e moda 5 . Neste contexto, vale observar o exposto por Manlow e Nobbs (2012) ao revelarem que a atmosfera criada para uma marca de luxo funciona como um condutor de relacionamentos com o mercado, como uma ferramenta de comunicação de marketing e, ainda, como um modelo de desenvolvimento da identidade da marca. Para Kapferer e Bastien (2009), o coração de uma marca de luxo é a sua imagem perante o mercado e seus clientes.

O terceiro fator obtido apresenta, como destaque positivo, o item 20 "esta marca tem credibilidade no mercado" apresenta média 4,51 (DP = 0,59) e moda 5. Sobre isto, Kapferer e Bastien (2009) discorrem que, para as marcas de luxo, não existe prestígio na ausência de respeito, colocando a credibilidade como elemento essencial ao desenvolvimento de marcas bem-sucedidas neste mercado.

No que tange ao ponto crítico, no sentido de ser pior avaliado comparativamente aos outros itens, o item 19 "esta marca é reconhecida no mercado como uma marca de luxo" revelou média 4,06 $(\mathrm{DP}=0,94)$ e moda 5 . Este resultado pode ter sido influenciado pela alta 
frequência da marca Zara, percebida pelas clientes como uma marca de luxo, mas que não teria a mesma imagem no mercado. Este resultado reforça a necessidade de um conceito unificador para luxo, visto que as pessoas tendem a confundir produtos de luxo com produtos premium, produtos de valor elevado ou, ainda, dependendo dos aspectos culturais associados à percepção do luxo, marcas importadas são tidas como sinônimos de marcas de luxo (STREHLAU, 2008).

Os resultados por ora obtidos delineiam um diagnóstico da percepção que as clientes de marcas de moda feminina de luxo têm em relação às iniciativas de marketing de relacionamento. Os pontos positivos destacados podem auxiliar a elaboração e implementação de estratégias de diferenciação de mercado capazes de trazer impacto positivo nos relacionamentos com os clientes. Outrossim, os pontos críticos identificados demandam atenção especial por parte dos gestores, no sentido de engendrar estratégias profícuas para estabelecer relacionamentos de longo prazo com suas clientes no mercado de moda feminina de luxo.

5.2.5 Verificação do ajuste do modelo global entre personalidade de marca e percepção de relacionamento com o cliente

O sexto e último objetivo proposto foi 'verificar o ajuste de um modelo estrutural de medição englobando as duas variáveis pesquisadas, a saber, percepção de relacionamento e personalidade atribuída à marca, sendo a personalidade de marca preditora da percepção de relacionamento com a marca'. Ademais, com a consecução deste objetivo, a validade nomológica da ERC Luxo também foi atestada.

Em primeiro lugar, foram analisadas as correlações entre todas as variáveis estudadas, a saber, a percepção de relacionamento com clientes no mercado de moda feminina de luxo, representada pelos três fatores obtidos na análise fatorial e as cinco dimensões de personalidade de marca no contexto brasileiro (MUNIZ; MARCHETTI, 2012). Visto que todas as correlações encontradas foram significativas, positivas e a maioria delas representou associação de moderada (>0,3) a forte (>0,5), conforme Cohen (1992), partiu-se para a análise de predição entre elas (FIELD, 2009), no caso a personalidade de marca como preditora da percepção de relacionamento. A Tabela 19 sintetiza as correlações entre as variáveis. 
Tabela 19 - Correlações entre as variáveis do estudo

\begin{tabular}{c|c|c|c|c|c}
\hline FATOR & CREDIBILIDADE & ALEGRIA & AUDÁCIA & SOFISTICAÇÃO & SENSIBILIDADE \\
\hline $\begin{array}{c}\text { EXPERIÊNCIA } \\
\text { COM A } \\
\text { MARCA }\end{array}$ &, $355^{* *}$ &, $229^{* *}$ &, $203^{* *}$ &, $243^{* *}$ &, $258^{* *}$ \\
\hline $\begin{array}{c}\text { FIDELIZAÇÃO } \\
\begin{array}{c}\text { IMAGEM DA } \\
\text { MARCA }\end{array}\end{array}$ &, $627^{* *}$ &, $375^{* *}$ &, $381^{* *}$ &, $419^{* * *}$ &, $327^{* * *}$ \\
\hline
\end{tabular}

Fonte: Elaborada pela autora

Nota: $* * \mathrm{p}<0,01$

Assim, para atingir o sexto objetivo, recorreu-se à análise de caminhos ou path analysis, ou teste do modelo estrutural, que visa testar relações entre variáveis, por meio da modelagem por equações estruturais, utilizando-se, mais uma vez, a estimação da máxima verossimilhança. A Figura 5 ilustra o modelo testado e a Tabela 20 apresenta os índices de ajuste obtidos.

Figura 5 - Resultado da path analysis para o modelo proposto

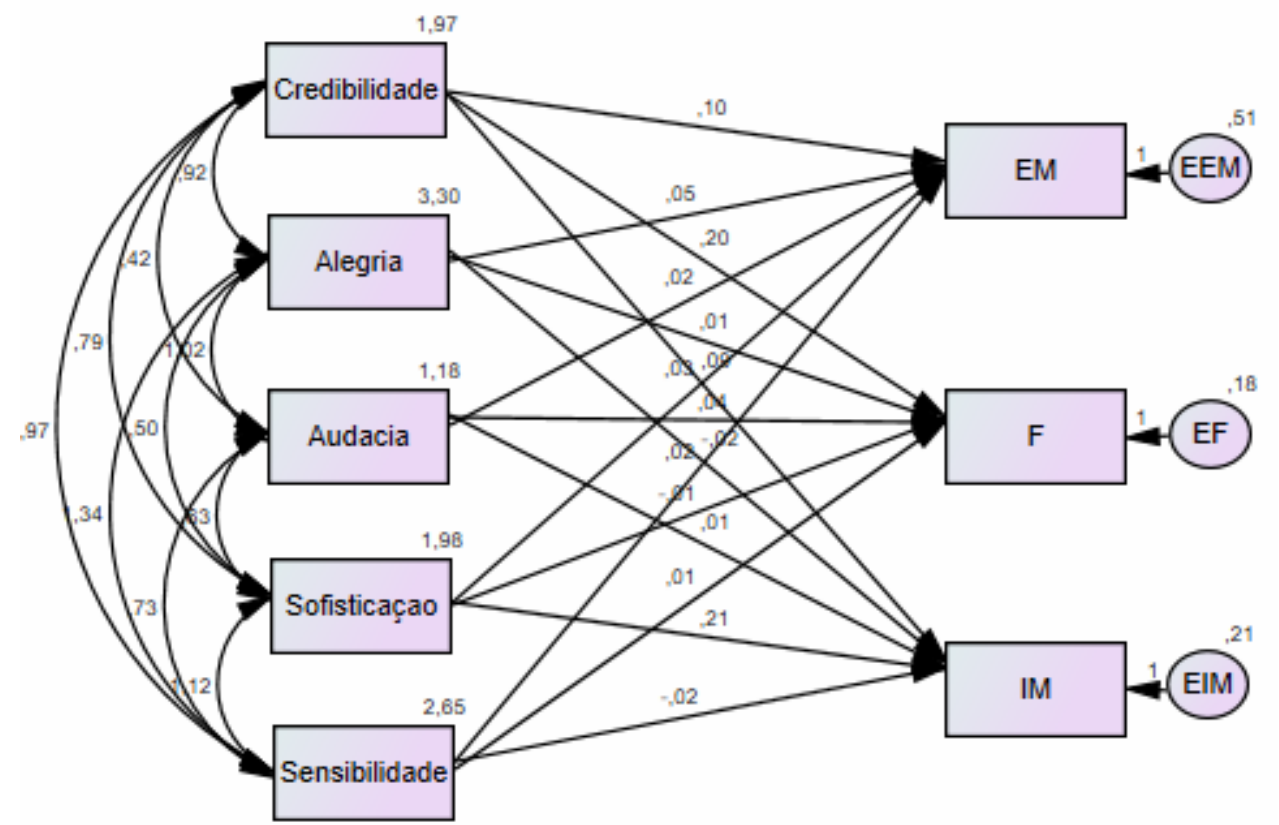

Nota. $\chi 2(3)=73,78 ; \mathrm{p}<0.001 ; \mathrm{NC}=24,59 ; \mathrm{GFI}=0,94 ; \mathrm{CFI}=0,90 ; \mathrm{RMSEA}=0,27$

Fonte: Elaborado pela autora 
Tabela 20 - Índices de adequação do modelo testado

\begin{tabular}{c|c|c}
\hline ÍNDICE & $\begin{array}{c}\text { VALORES } \\
\text { IDEAIS }\end{array}$ & MODELO \\
\hline NC & Inferior a 3 & 24,59 \\
\hline & $\begin{array}{c}\text { Superior a } \\
\text { 0,9/Próximo de } \\
\text { GFI }\end{array}$ & \\
\hline CFI & Superior a 0,9 & 0,94 \\
\hline RMSEA & Inferior a 0,08 & 0,91 \\
\hline
\end{tabular}

Fonte: Elaborada pela autora

Tomando como base os parâmetros de ajuste propostos por Kline (2011) e já elencados no objetivo específico III, o modelo estrutural testado apresentou ajuste satisfatório, uma vez que o índice incremental (CFI) esteve dentro dos valores esperados.

Quanto aos índices absolutos (NC e RMSEA), estes não estiveram dentro dos valores de referência porque são sensíveis ao tamanho da amostra. O $\chi 2$ é uma função matemática que depende do tamanho da amostra $(\mathrm{N})$; à medida que $\mathrm{N}$ aumenta, o mesmo ocorre com $\chi^{2}$, mesmo quando as diferenças entre as matrizes de variância observada e estimada são idênticas (HAIR et al., 2009). Neste sentido, os autores argumentam que modelos estruturais contendo cinco construtos ou menos, cada um com ao menos três variáveis, podem ser estimados com amostras de 100 a 150 sujeitos. Quanto ao RMSEA, conforme Rigdon (1996), um exame empírico de diversas medidas determinou que o RMSEA configura uma medida mais adequada para uso de modelos confirmatórios, aumentando sua eficácia. Pode-se conjeturar ainda que a medida de personalidade de marca pode apresentar algum problema de ajuste, uma vez que em sua validação original (MUNIZ; MARCHETTI, 2012), grande parte dos índices não apresentaram bom ajuste, o que pode ter contribuído para a obtenção de índices absolutos ruins ( $\chi 2$ e RMSEA) no teste do modelo estrutural por ora realizado.

Destarte, optou-se por utilizar a medida de ajuste absoluto denominada índice de qualidade do ajuste (GFI), por ser menos sensível ao tamanho amostral. Segundo Kline (2011), valores próximos a 0,95 indicam bom ajuste. Por isso, concluiu-se que o modelo estrutural mostrando a influência da personalidade de marca na percepção de relacionamento possui ajuste satisfatório. 
Por fim, as fortes correlações entre os fatores de personalidade de marca e os fatores de percepção de relacionamento, conforme ilustra a Figura 6, atestaram a validade nomológica da ERC Luxo e, em última análise, sua validade de construto.

A Figura 6 sintetiza os resultados da path analysis, desvelando a quantidade da variância da variável dependente, no caso, a percepção de relacionamento, que é explicada conjuntamente pelas variáveis independentes $\left(\mathrm{R}^{2}\right)$, no caso, as dimensões da personalidade de marca atribuída, bem como o coeficiente de correlação padronizada que representa a magnitude e a direção do relacionamento entre cada um dos preditores (variáveis independentes) e a variável critério (variáveis dependentes).

Figura 6 - Síntese do modelo de predição

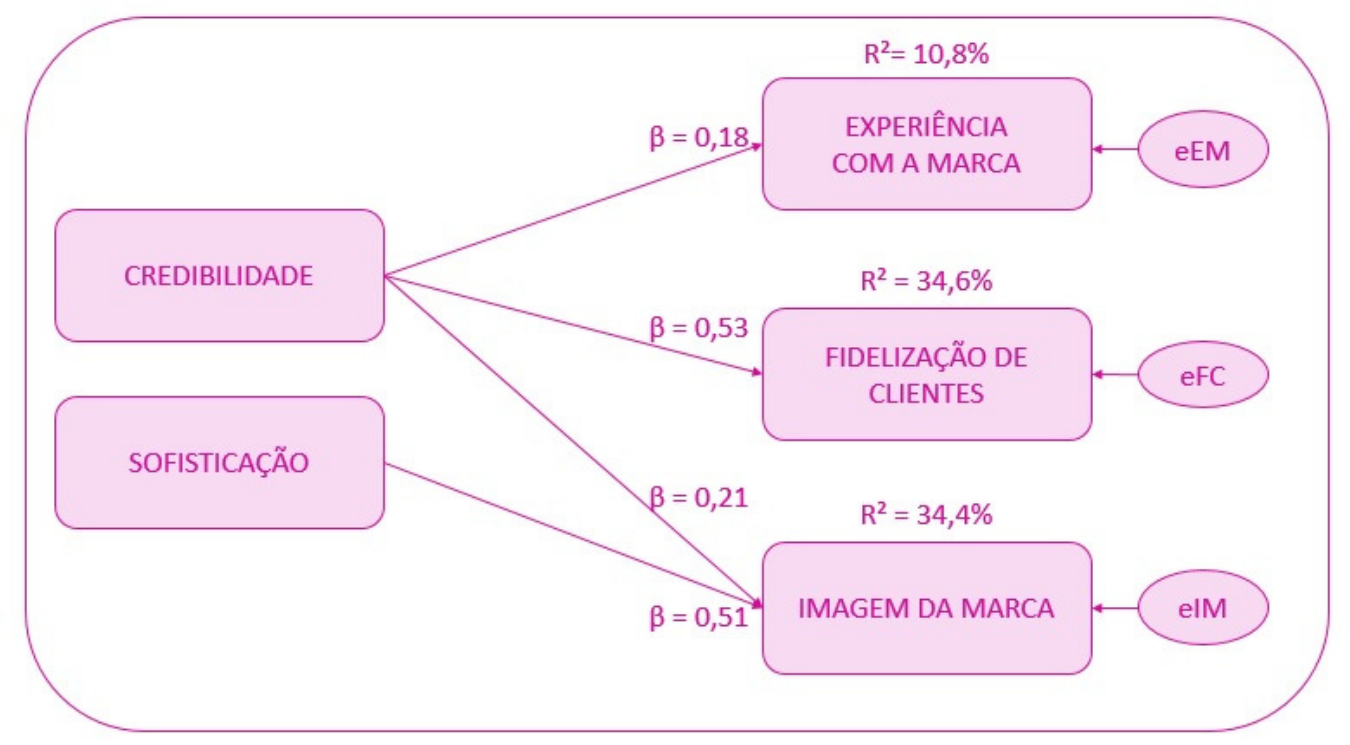

Fonte: Elaborada pela autora

Entre as dimensões de personalidade de marca, a de Credibilidade apresentou correlações fortes com todos os fatores de percepção de relacionamento, seguida da dimensão Sofisticação e sua forte relação com o fator Imagem da Marca.

Sobre a interpretação que se dá para a significância estatística do coeficiente de determinação da variância $\left(\mathrm{R}^{2}\right)$ no âmbito das ciências comportamentais, considera-se $2 \%$ como um pequeno efeito, $13 \%$ como médio efeito e, a partir de $26 \%$, grande efeito (COHEN, 1992). Constata-se, assim, pelos resultados obtidos, que a dimensão credibilidade contribui com 10,8\% para a explicação da experiência com a marca, apresentando um pequeno poder preditivo; já no que tange à fidelização dos clientes, a credibilidade contribui sozinha com $34,6 \%$ para sua explicação, mostrando grande poder de predição. Por fim, a imagem da marca 
pode ser explicada tanto pela credibilidade $(\beta=0,21)$ quanto pela sofisticação $(\beta=0,51)$, sendo esta última sua melhor preditora. Estas duas dimensões apresentam grande efeito na explicação da imagem de marca $(34,41 \%)$.

Este resultado corrobora os três elementos que promovem o engajamento com as marcas de luxo, a saber, (1) aspectos funcionais, relativos aos atributos dos produtos; (2) aspectos experienciais, referentes às interações que os consumidores experimentam com as marcas; e (3) o aspecto simbólico, que representa os atributos intangíveis e os laços emocionais com o produto ou marca (BERTHON; PITT; PARENT; BERTHON,2009).

No que tange à experiência com a marca, a literatura assegura que um dos princípios básicos da venda de produtos de luxo consiste na experiência sensorial e simbólica da compra (KAPFERER; BASTIEN, 2009). Neste sentido, uma vez que o consumo de produtos de luxo está relacionado ao consumo hedônico, a experiência de compra carrega, ainda, a função de prazer e diversão aos consumidores, independente da compra em si (BABIN; DARDEN; GRIFFIN, 1994).

Sobre o impacto da credibilidade da marca sobre a experiência com ela, Dubois, Laurent e Czellar (2001) revelam as características do produto de luxo que influenciam a experiência com a marca, quais sejam, qualidade excelente, preço elevado, raridade, estética do produto, aspectos multissensoriais e a tradição e história da marca. Dentro desta perspectiva, Sthrelau (2013) observa o caráter transitório do luxo e seu dinamismo, onde o valor do luxo passou do produto para a marca e, atualmente, está associado à experiência do consumidor.

Ainda sobre a credibilidade, no sentido dos valores percebidos de uma marca, ela tende a influenciar o consumo de marcas de luxo e tornar possível o desenvolvimento de lealdade à marca, entendida como a fidelização dos consumidores (WILLIAMS; ATWAL, 2013). Para Chevalier e Mazzalovo (2008), o sucesso de uma marca no mercado de luxo está ligado à sua capacidade de construir uma marca corporativa consistente e distinta entre os competidores, conhecendo as preferências do consumidor e adequando-se às mesmas, o que tendem em última análise, a promover a lealdade à marca.

Em se tratando da relação entre credibilidade e imagem de marca, a literatura garante que a imagem da marca é formada a partir de sinais emitidos pela própria marca, que delineiam a percepção que o mercado tem sobre ela (BIEL, 1993; KAPFERER, 2008; KELLER, 2012). Biel (1993), especificamente, aponta a imagem da organização como elemento chave na formação da imagem da marca. Sob perspectiva semelhante, Fennell 
(1978) sugere que, entre os fatores que conduzem o consumidor à escolha de um produto, a credibilidade de uma marca influencia a tomada de decisão devido à sua associação à redução de riscos. Neste sentido, a imagem positiva de uma marca, formada no mercado por meio das avaliações dos produtos ou da própria marca, é impactada pela sua credibilidade perante os concorrentes.

No que se refere à relação entre sofisticação e imagem de marca, a literatura aponta que o consumo de produtos de luxo está associado à busca de status social, como forma de obter prestígio e reconhecimento (LEIBENSTEIN, 1950; CASTARÈDE, 2005; ALLÉRÈS, 2006; STHRELAU, 2013).

Neste sentido, visto que a imagem da marca é formada por diferentes elementos que a projetam no mercado (BIEL, 1993; KAPFERER, 2008; KELLER, 2012), Lipovetsky e Roux (2005) discorrem sobre a estética utilizada pelas marcas de luxo para criar ambientes que remetam à sofisticação e ao refinamento, englobando matérias-primas raras, produção de peças artesanais, atendimento exclusivo, arquitetura e ambientação cuidadosa das lojas contexto em que se inserem mobília, sons, cores e aromas e até mesmo a atenção destinada à beleza e sofisticação das embalagens. Posto isto, Keller (2008) defende a sintonia entre todos os aspectos do composto de marketing de uma marca de luxo, de maneira a reforçar a imagem da marca. Cabe salientar, ainda, que a imagem da marca configura o mais importante ativo de uma marca de luxo (ALBRECHT; BACKHAUS; WOISETSCHLAGER, 2013). Para os autores, a manutenção deste ativo demanda o contínuo desenvolvimento da atmosfera de sofisticação, confirmando o encantamento do consumidor em relação à marca.

Por conseguinte, respondendo à pergunta desta pesquisa, a resposta é afirmativa, visto que foi confirmada a predição da personalidade de marca na percepção de relacionamento com clientes no contexto das marcas de moda feminina de luxo.

Para concluir, considerando as clientes de marcas de moda feminina de luxo, tem-se que credibilidade e sofisticação declararam-se os aspectos mais relevantes para a construção e o desenvolvimento de relacionamentos, visto que este sofre a influência da identificação pessoal com a marca. Com isto, o bom desempenho das marcas deste segmento no cenário competitivo está relacionado às estratégias vinculadas aos aspectos emocionais e relacionais incitados pelos produtos de moda feminina de luxo.

Nesta perspectiva, cabe aos gestores de marcas de moda feminina de luxo o engajamento nos processos de criação de valor do consumidor, mapeando suas preferências, opiniões e desejos, de forma a criar experiências com a marca capazes de impactar a sua 
lealdade. Recomenda-se, ainda, intensificar os aspectos relacionados à experiência com a marca, identificando os clientes lucrativos e apresentando ofertas personalizadas.

Em tempos de alta competitividade, a união de aspectos emocionais, representados pela personalidade de marca, e de aspectos relacionais, pelo desenvolvimento de relacionamentos com clientes, cumpre não somente a função de satisfazer as necessidades dos consumidores e de gerar lucratividade às organizações, mas configura uma poderosa estratégia de posicionamento de marca dentro de um segmento do luxo.

A seguir, a conclusão do estudo. 


\section{CONCLUSÃO}

O presente estudo permitiu alcançar os objetivos estabelecidos, garantindo, assim, a consecução do objetivo geral, além de revelar aspectos relevantes à literatura de marketing sobre personalidade de marca e relacionamento com o consumidor no mercado de moda feminina de luxo.

Assim, este capítulo pretende apresentar uma síntese dos resultados da pesquisa empreendida, contribuições acadêmicas, implicações gerenciais, limitações e sugestões para pesquisas futuras.

\subsection{Síntese dos Principais Resultados}

Este estudo buscou avaliar, em seu objetivo geral, a relação entre a personalidade de marcas de moda feminina de luxo atribuídas pelas clientes e a percepção de seu relacionamento com tais marcas. Como resultado, tem-se que as personalidades de credibilidade e sofisticação atribuídas às marcas de moda feminina de luxo são preditoras da percepção que as clientes têm do seu relacionamento com tais marcas. A credibilidade foi preditora das três dimensões da percepção de relacionamento, desvelando pequena, média e grande explicação para experiência com a marca, fidelização e imagem de marca, respectivamente. Já a sofisticação foi a principal preditora da imagem de marca, apresentando forte influência sobre ela.

Para a consecução do objetivo específico I, desenvolver uma escala de relacionamento com clientes de marcas de moda feminina de luxo, foi realizada uma etapa qualitativa, acrescentando ao instrumento original (DEMO; ROZZETT, 2013) itens que contemplaram o contexto das marcas femininas de luxo. Para o objetivo seguinte, validar a escala de relacionamento com clientes de marcas de moda feminina de luxo, a ERC Luxo confirmou os três fatores obtidos na etapa qualitativa, a saber, experiência com a marca, fidelização de clientes e imagem da marca, resultando em uma escala de 23 itens. No objetivo III, realizouse a validação confirmatória do modelo exploratório de mensuração do relacionamento com marcas de moda feminina de luxo obtido no objetivo II, onde o modelo de mensuração multidimensional da ERC Luxo foi confirmado e manteve os três fatores, mas com 20 itens. 
No que tange ao objetivo IV, identificar a personalidade atribuída às marcas de moda feminina de luxo mais citadas pelas clientes pesquisadas, quais sejam, Zara, Louis Vuitton, Chanel, Michael Kors e Le lis Blanc, o estudo revelou que a Sofisticação foi a dimensão mais percebida pelas clientes, seguida de Audácia e Credibilidade. ,

Quanto à percepção do relacionamento com clientes, cumprindo o objetivo $\mathrm{V}$, o fator Fidelização de Clientes apresentou-se como o melhor representante do construto Relacionamento com Clientes, seguido pelo fator Imagem da Marca. Não obstante, o fator Experiência da Marca revelou-se ponto crítico, demandando maior atenção por parte dos gestores do mercado de moda feminina de luxo.

Por fim, o objetivo VI, que visava verificar o ajuste de um modelo estrutural de medição englobando as duas variáveis pesquisadas, a saber, percepção de relacionamento e personalidade atribuída à marca, sendo a personalidade de marca preditora da percepção de relacionamento com a marca, revelou um ajuste satisfatório, com fortes correlações entre os fatores de personalidade de marca e os fatores de percepção de relacionamento.

Desta forma, tem-se o cumprimento do objetivo geral, respondendo à problemática da pesquisa, visto que as personalidades credibilidade e sofisticação atribuídas às marcas de moda feminina de luxo de fato influencia a percepção do relacionamento que as clientes têm com tais marcas.

\subsection{Contribuições Acadêmicas e Gerenciais}

A presente pesquisa, desde a revisão teórica até a apresentação dos resultados, contribuiu para os estudos nas áreas de marketing de relacionamento e comportamento do consumidor, preenchendo uma lacuna identificada na literatura, visto que não foram encontrados estudos que explorassem a relação entre Personalidade de Marca e Marketing de Relacionamento. Ainda, o estudo abrange o mercado de luxo, segmento com potencial de crescimento e carente de estudos científicos que explorem seu contexto de atuação.

Ademais, o estudo propôs a validação exploratória e confirmatória de um instrumento de pesquisa, cujo resultado é a ERC Luxo, com bons índices psicométricos, podendo ser usada para posteriores estudos relacionais no contexto do mercado de luxo.

No que tange às implicações gerenciais, a ERC Luxo representa uma ferramenta para o diagnóstico do relacionamento com clientes do mercado de moda feminina de luxo, oferecendo ao mercado um instrumento de mensuração válido e confiável, capaz de orientar a tomada de decisão por parte dos gestores no sentido de aprimorar tanto a imagem quanto a 
experiência com a marca, o que se traduzirá, em última análise, em uma maior lealdade das clientes.

Por fim, o estudo evidenciou a relevância da credibilidade e da sofisticação na construção de relacionamentos com clientes do mercado de luxo, na melhoria da imagem das marcas no mercado e, ainda, na percepção de experiências otimizadas com elas. Destarte, profissionais de marketing de luxo devem considerar, no desenho de suas estratégias de marca, aspectos que remetam à sofisticação, considerando as características chique, elegante, alta-classe e glamorosa; e que remetam, também, à credibilidade, evidenciando traços de responsabilidade, segurança, confiança, respeito, lealdade e consistência.

\subsection{Limitações e Recomendações para Estudos Futuros}

No que tange às limitações e recomendações para futuras pesquisas, este trabalho consiste em um primeiro esforço no sentido de construir um quadro conceitual para o relacionamento com clientes no mercado de moda feminina de luxo, incluindo o impacto da personalidade atribuída às marcas deste segmento sobre a percepção de relacionamento com elas. Posto isto, tem-se a primeira limitação, onde os resultados obtidos revelam-se mais indicativos do que conclusivos. Assim, novas validações da ERC Luxo em outros contextos e diferentes perfis confirmarão a estabilidade do modelo e incrementarão sua generalidade e validade externa.

Outra limitação deve-se ao caráter transversal do estudo. Neste sentido, requer-se o desenvolvimento de uma base de dados de séries temporais, seguido do teste da estrutura da ERC Luxo validada neste estudo em um contexto longitudinal, de maneira a se obter um maior refinamento da escala. Novas validações da ERC Luxo são recomendadas com base em futuras tendências e perspectivas em marketing de relacionamento para o segmento do luxo, a fim de que uma medida confiável do CRM no mercado de luxo possa ser construída em uma base contínua. Neste contexto, pode ser necessário alterar, acrescentar ou até mesmo eliminar algum item da escala.

Sugere-se, ainda, o estudo de marcas de luxo masculinas ou unissex (ex.: automóveis, tecnologia, cosméticos, hotelaria) no afã de verificar se a estrutura por ora obtida da ERC Luxo se confirma com públicos e produtos diversificados, dentro do mercado de luxo.

Outrossim, quanto ao estado da arte da variável Personalidade de Marca, observou-se a predominância de estudos oriundos da psicologia, ensejando pesquisas futuras sobre o construto dentro do campo da administração, haja vista sua forte influência no marketing de 
relacionamento. Sugere-se, ainda, novos estudos para melhorar o modelo de mensuração da personalidade de marca, uma vez que problemas no ajuste desta medida podem ter contribuído para a obtenção de índices absolutos ruins ( $\chi 2$ e RMSEA) no teste do modelo estrutural realizado nesta pesquisa.

Por fim, apesar das limitações apresentadas, o principal objetivo deste estudo foi alcançado, desvelando a influência da atribuição de personalidade de marcas na construção de relacionamento com elas. Ademais, um instrumento que avalia os aspectos considerados relevantes para o desenvolvimento de relacionamentos com clientes no mercado de moda feminina de luxo foi produzido, apresentando consistência teórica, confiabilidade e validade de construto. Considerando a crescente relevância do papel estratégico do CRM para as organizações atualmente, mormente no mercado de luxo, ainda pouco estudado, a presente pesquisa propõe uma medida operacional válida e confiável deste construto. Os resultados aqui coligidos não são conclusivos, mas oferecem um ponto de partida útil para a realização de futuras investigações que contribuam para o avanço progressivo do conhecimento teóricoempírico concernente ao CRM no mercado de luxo. 


\section{REFERÊNCIAS}

AA, Z. V.; BLOEMER, J.; HENSELER, Jörg. Using customer contact centres as relationship marketing instruments. Service Business, v. 9, n. 2, p. 185-208, 2013.

AAKER, D. Measuring brand equity across products and markets. California Management Review, v. 38, n. 3, p. 103, 1996.

AAKER, D. Brand Equity, gerenciando o valor da marca. São Paulo: Negócio, 1998.

AAKER, D.; JOACHIMSTHALER, E. Como construir marcas líderes. São Paulo: Futura, 2000.

AAKER, J. Dimensions of brand personality. Journal of Marketing Research, v. 34, n. 3, p. 347-356. 1997.

AAKER, J.; BENET-MARTINEZ, V.; GAROLERA, J. Consumption symbols as carries of culture: a study of japaneseand Spanish brand personality constructs. Journal of Personality and Social Psychology, v.81, n.3, p.492-508, 2001.

ABBADE, E. B. A Percepção de Clientes Universitários sobre o Relacionamento com suas Operadoras de Telefonia Móvel. REGE Revista de Gestão, v. 21, n. 3, p. 433-448, 2014.

AGARIYA, A. K.; SINGH, D. CRM Scale Development and Validation in Indian Public Hospitals. Journal of Health Management, v. 15, n. 2, p. 275-291, 2013.

AGARIYA, A. K.; SINGH, D. CRM index development and validation in Indian banking sector. International Journal of Customer Relationship Marketing and Management, v. 3, n. 2, p. 10-32, 2012 b.

AGARIYA, A. K.; SINGH, D. CRM scale development \& validation in Indian insurance sector. Journal of Internet Banking and Commerce, v. 17, n. 2, p. 1-21, 2012a. 
AILAWADI, K. L.; LEHMANN, D.R.; NESLIN, S. A. Revenue premium as an outcome measure of brand equity. Journal of Marketing, v.67, p.1-17, 2003.

AKIN, M. Predicting consumers' behavioral intentions with perceptions of brand personality: A study in cell phone markets. International Journal of Business and Management, v. 6, n. 6, p. 193, 2011.

AKROUSH, M. N.; DAHIYAT, S. E.; GHARAIBEH, H. S.; ABU-LAIL, B. N. Customer relationship management implementation: an investigation of a scale's generalizability and its relationship with business performance in a developing country context. International Journal of Commerce and Management, v. 21, n. 2, p. 158-190, 2011.

ALBRECHT, C.; BACKHAUS, H.; WOISETSCHLAGER, D. M. Drivers of Brand Extension Success: What Really Matters for Luxury Brands. Psychology \& Marketing, v. 30, n. 8, p. 647-659, 2013.

ALLPORT, G. W. Personalidade: padrões e desenvolvimento. São Paulo: EPU, Edição da Universidade de São Paulo, 1973.

ALLÉRÈS, D. Luxo... estratégias/marketing. 2. ed. Rio de Janeiro: Editora FGV, 2006.

ALMEIDA, S.O.; LOPES, T.C.; PEREIRA, R.C.F. A produção científica em marketing de relacionamento no Brasil entre 1990 e 2004. In: Encontro da Associação Nacional de PósGraduação e Pesquisa em Administração, 30. Rio de Janeiro. Anais... Rio de Janeiro: ANPAD, 2006.

AMA. American Marketing Association. Disponível em: <http://www.marketingpower.com>. Acesso em: 10 ago. 2014.

AMARAL, T. C.; CAMARGO, J. B.; PIZZINATTO, A. K.; PITOMBO, T. C. D. T. Influências do Comércio Eletrônico B2B no Processo de Atendimento de Pós-Vendas no Segmento de Bens de Capital: Estudo de Caso em uma Empresa Representante de Equipamentos Pesados. Revista Brasileira de Marketing, v. 14, n. 2, p. 86-99, 2015. 
ARAÚJO, R. F.; ALVARENGA, L. A bibliometria na pesquisa científica da pós-graduação brasileira de 1987 a 2007. Revista Eletrônica de Biblioteconomia e Ciência da Informação, v. 16, n. 31, p. 51-70, 2011.

ARSENA, A.; SILVERA, D. H.; PANDELAERE, M. Brand trait transference: When celebrity endorsers acquire brand personality traits. Journal of Business Research, v. 67, n. 7, p. 1537-1543, 2014.

ASHLEY, C.; NOBLE, S. M.; DONTHU, N.; LEMON, K. N. Why customers won't relate: Obstacles to relationship marketing engagement. Journal of Business Research, v. 64, n. 7, p. 749-756, 2011.

ATWAL, G.; WILLIAMS, A. Luxury brand marketing - The experience is everything!. Journal of Brand Management, v. 16, n. 5, p. 338-346, 2009.

AVIS, M. Brand personality factor based models: A critical review. Australasian Marketing Journal, v. 20, n. 1, p. 89-96, 2012.

AVIS, M.; AITKEN, R.; FERGUSON, S. Brand relationship and personality theory metaphor or consumer perceptual reality?. Marketing Theory, v. 12, n. 3, p. 311-331, 2012.

AZOULAY, A. The malleable personality of brands: the winning facets. Proceedings Proceedings of the 34th EMAC Colloquium, Milão, Itália. 2005.

AZOULAY, A.; KAPFERER, J-N. Do brand personality scales really measure brand personality? Brand management, v.11, n.2, Nov 2003.

AWASTHI, P.; SANGLE, P. S. Adoption of CRM technology in multichannel environment: a review (2006-2010). Business Process Management Journal, v. 18, n. 3, p. 445-471, 2012. 
BABIN, B. J.; DARDEN, W. R.; GRIFFIN, M. Work and/or fun: measuring hedonic and utilitarian shopping value. Journal of consumer research, p. 644-656, 1994.

BAIN \& COMPANY. Luxury Goods Worldwide Market Study. Boston, 2013.

BALLANTYNE, D.; CHRISTOPHER, M.; PAYNE, A. Relationship marketing: looking back, looking forward. Marketing Theory, v. 3, n. 1, p. 159-166, 2003.

BARDIN, L. Análise de conteúdo. Lisboa: Edições 70, 2014.

BASTIEN, V.; KAPFERER, J. More on Luxury anti-laws of Marketing. In: Luxury Marketing. Gabler Verlag, 2013. p. 19-34.

BATELLI, L.S.; DEMO, G. Desenvolvimento e validação de uma escala para avaliar o relacionamento entre jogadores e os jogos do Nintendo Wii. In: Encontro Nacional de Engenharia de Produção, 32. Bento Gonçalves. Anais... Rio de Janeiro: ABEPRO, 2010.

BATTISTELLA, L. F.; BICHUETI, R. S.; GROHMANN, M. Z. Personalidade de Marca: um Estudo da Percepção dos Consumidores da Eny Comércio de Calçados. Revista ADM. MADE, v. 15, n. 1, p. 56-74, 2011.

BATTOR, M.; BATTOR, M. The impact of customer relationship management capability on innovation and performance advantages: testing a mediated model. Journal of Marketing Management, v. 26, n. 9-10, p. 842-857, 2010.

BATRA, R.; LEHMAN, R.; SINGH, D. The brand personality component of brand goodwill: some antecedents and consequences. IN: AAKER, D.; BIEL, A. Brand Equity and Advertising. New Jersey: Lawrence Erlbaum Associates, 1993.

BBC. Brasil. As dez tendências globais de consumo em 2014. Disponível em: < http://www.bbc.co.uk/portuguese/noticias/2014/01/140115_relatorio_euromonitor_dez_tende ncias_globais_de_consumo_lgb >. Acesso em: 10 nov. 2014.

BENOUAKRIM, H.; EL KANDOUSSI, F. Relationship marketing: literature review. International Journal of Science and Research, v. 2, n. 10, p. 148-152, 2013. 
BERRY, L. L. Relationship marketing of services - growing interest, emerging perspectives. Journal of the Academy of Marketing Science, v. 23, n. 4, p. 236-245, 1983.

BERRY, L. L. Relationship marketing of services-growing interest, emerging perspectives. Journal of the Academy of Marketing Science, v. 23, n. 4, p. 236-245, 1995.

BERRY, L. L.; GRESHAM, L. G. Relationship retailing: transforming customers into clients. Business Horizons, v. 29, n. 6, p. 43-47, 1986.

BERRY, N. C. Revitalizing brands. Journal of Consumer Marketing, v. 5, n. 3, p. 15-20, 1988.

BERTHON, P.; PITT, L.; PARENT, M.; BERTHON, J. Aesthetics and Ephemerality. California Management Review, v. 52, n. 1, 2009.

BHARADWAJ, S. G.; VARADARAJAN, P. R.; FAHY, J. Sustainable competitive advantage in service industries: a conceptual model and research propositions. The Journal of Marketing, p. 83-99, 1993.

BIEL, A. Converting image into equity. In: AAKER, D. A., BIEL, A. (Org.). Brand equity and advertising: Advertising's role in building strong brand. Hillsdale, NJ: Laurence Erlbaum Associates, 1993. p. 67-82.

BLACKSTON, M. Beyond brand personality: Building brand relationship. In: AAKER, D. A., BIEL, A. (Org.). Brand equity and advertising: Advertising's role in building strong brand. Hillsdale, NJ: Laurence Erlbaum Associates, 1993. p. 113-124.

BOSNJAK, M.; BOCHMANN, V.; HUFSCHMIDT, T. Dimensions of Brand Personality Attributions: A Person-Centric Aproach in the German Cultural Context. Social Behavior and Personality: an international journal, v. 35, n. 3, p. 303-316, 2007. 
BRAGA, J. Sobre o luxo. Revista Costura Perfeita, São Paulo, n.10, 2004.

BRAMBILLA, F. R. Análise qualitativa da produção acadêmica brasileira sobre Customer Relationship Management (CRM): o primeiro passo em busca da consolidação conceitual. Revista Ciências Exatas e Naturais, v. 12, n. 2, p. 295-326, 2010.

BRANAGHAN, R. J.; HILDEBRAND, E. A. Brand personality, self-congruity, and preference: A knowledge structures approach. Journal of Consumer Behaviour, v. 10, n. 5, p. 304-312, 2011.

BRETZKE, M. Marketing de Relacionamento e competição em tempo real. São Paulo: Editora atlas, 2000.

BRITO, C. Uma abordagem relacional ao valor da marca. Revista Portuguesa e Brasileira de Gestão, v. 9, n. 1-2, p. 49-63, 2010.

BRITO, E. P. Z.; MARIOTTO, G. Benefits of Cooperation between Buyers and Providers: a study in the field of information and communications technology. Review of Business Management, v. 15, n. 47, p. 241-261, 2013.

BYRNE, B. M. Structural equation modeling with AMOS: Basic concepts, applications, and programming. Routledge, 2013.

CAMPBELL, A. J. Creating customer knowledgement competence: managing customer relationship management programs strategically. Industrial Marketing Management, v. 32, p. 375-383, 2003.

CAMPOS, L. M. S.; SILVEIRA, R. B.; MARCON, R. Elementos do marketing na captação de recursos do terceiro setor. Revista de Administração Mackenzie, v. 8, n. 3, p. 104-127, 2007. 
CAPEGEMINI; RBC WEALTH MANAGEMENT. Relatório sobre a Riqueza Mundial 2012. Nova York: 2012.

CAPRARA, G. V.; BARBARANELLI, C.; GUIDO, G. Personality as metaphor: extension of the psycholexical hypothesis and the five factor model to brand and product personality description. European Advances in Consumer Research, v.3, p.61-69, 1998.

CAPRARA, G. V.; BARBARANELLI, C.; GUIDO, G. Brand personality: how to make the metaphor fit? Journal of Economic Psychology, v.22, p.377-395, 2001.

CARDOSO, H. J. Desenvolvimento e Validação de uma Escala de Relacionamento para Clientes de Telecom. Universidade de Brasília: Trabalho de Conclusão de Curso. Brasília, 2014.

CASTARÈDE, J. O Luxo - Os segredos dos produtos mais desejados do mundo. São Paulo: Barcarolla, 2005.

CHAN, P.; SAUNDERS, J.; TAYLOR, G.; SOUCHON, A. Brand personality perception: regional or country specific?. European Advances in Consumer Research, v. 6, p. 300-307, 2003.

CHEVALIER, M.; MAZZALOVO, G. Luxury brand management: a world of privilege. John Wiley \& Sons, 2008.

CHIN, W. W. The partial least squares approach to structural equation modeling. Modern methods for business research, v. 295, n. 2, p. 295-336, 1998.

COCHRAN, W. G. Sampling Techniques. 3.ed., New York: John Wiley \& Sons, Inc. 1977.

COHEN, J. A power primer. Psychological bulletin, v. 112, n. 1, p. 155, 1992. 
COMIOTTO, F. D.; COSTA, J. I. P.; SANTOS, A. R.; MONDO, T. S. Comprei Meu Carro, o que vem Depois? Análise da Percepção e da Importância Atribuídas por Clientes em Serviços de Pós-Venda. Revista Brasileira de Marketing, v. 13, n. 6, p. 80-93, 2014.

COMREY, A. L.; LEE, H. B. A First Course in Factor Analysis. New York. 1992.

CORTINA, J. M. What is coefficient alpha? An examination of theory and applications. Journal of applied psychology, v. 78, n. 1, p. 98, 1993.

COSTA, P. T.; MCCRAE, R. R. Four ways five factors are basic. Personality and individual differences, v. 13, n. 6, p. 653-665, 1992.

COSTA, P. T.; MCCRAE, R. R. Personality in adulthood: a six-year longitudinal study of self-reports and spouse ratings on the NEO Personality Inventory. Journal of personality and social psychology, v. 54, n. 5, p. 853, 1988.

COYNE, K.P. Sustainable competitive advantage - What it is, what it isn't. Business Horizons, v. 29, n. 1, p. 54-61, 1986.

CREMONEZI, G.; PIZZINATTO, N. K.; GIULIANI, A. C.; SPERS, V. R. E.; OSWALDO, Y. C. As Indústrias de Produtos Orgânicos, o Marketing de Relacionamento e o Endomarketing: Estudo de Múltiplos Casos. Revista Organizações em Contexto-online, v. 9, n. 17, p. 343-367, 2013.

CUNHA, A. L.; LUCE, F. B.; KLERING, L. R. O valor de marca para o consumidor final a partir do conceito de brand equity em bens de conveniência. Anais do XXI ENANPAD, Angra dos Reis, 1997.

D’ANGELO, A. C. Precisar, não precisa. Um olhar sobre o consumo de luxo no Brasil. São Paulo: Lazuli, 2006. 191 p. 
D'ANGELO, A. C.; SCHNEIDER, H.; LARÁN, J. A. Marketing de relacionamento junto a consumidores finais: um estudo exploratório com grandes empresas brasileiras. Revista de Administração Contemporânea, v. 10, n. 1, p. 73-93, 2006.

DAVE, K.; DHAMIJA, G. Luxury Buying Behaviour and the Role of Culture: An Indian Context. In: WIEDMANN, K.; HENNINGS, N. (Org.). Luxury Marketing: A Challenge for Theory and Practice. Springer Gabler, 2013. p. 157-168.

DA ROCHA, L.; CLARO, D. P. Impacto do Marketing de Relacionamento sobre a Recomendação: Evidência do Varejo de Materiais de Construção Brasileiro. Revista Brasileira de Marketing, v. 12, n. 3, p. 123-151, 2013

DAS, K. Relationship marketing research (1994-2006): an academic literature review and classification. Marketing Intelligence \& Planning, v. 27, n. 3, p. 326-363, 2009.

DAY, G. S. Managing market relationships. Journal of the Academy of Marketing Science, v. 28, n. 1, p. 24-30, 2000.

DAY, G. S.; WENSLEY, R. Assessing advantage: a framework for diagnosing competitive superiority. The Journal of Marketing, p. 1-20, 1988.

DE CHERNATONY, L. Construção de marca. IN: BAKER, M. (Org.). Administração de Marketing. Rio de Janeiro: Elsevier, 2005. p. 263-279.

DE LIMA, A. A.; BAPTISTA, P. P. Impacto da Congruência entre Autoconceito e Personalidade de Marca na Intensidade da Qualidade de Relacionamento e Lealdade do Consumidor. Revista Brasileira de Marketing, v. 12, n. 1, p. 73-96, 2013.

DE SÁ, R. R. L. G.; MARCONDES, R. C. O ponto de vendas de produtos de luxo da moda de vestuário feminino no Brasil. CADERNOS EBAPE, v. 8, n. 3, p. 514-534, 2010.

DEMO, G. FOGAÇA, N.; PONTE, V.; FERNANDES, T.; CARDOSO, H. Marketing de Relacionamento (CRM): Estado da Arte, Revisão Bibliométrica da Produção Nacional de 
Primeira Linha, Institucionalização da Pesquisa no Brasil e Agenda de Pesquisa. Revista de Administração Mackenzie, v. 16, n. 5, 2015.

DEMO, G.; PESSÔA, R. CRM na administração pública: desenvolvimento e validação de uma Escala de Relacionamento com o Cidadão (ERCi). Revista de Administração Pública, v. 49, n. 3, p. 677-697, 2015.

DEMO, G; PONTE, V. Marketing de relacionamento (CRM): estado da arte e estudos de casos. Brasília: Atlas, 2008.

DEMO, G.; ROZZETT, K. O.; PONTE, J. V. A.; FERREIRA, L. A.; MENDES, N.M.D. Marketing de Relacionamento (CRM): Estado da arte, produção nacional na primeira década do milênio e agenda de pesquisa. In: Encontro da Associação Nacional de Pós-Graduação e Pesquisa em Administração, 35. Rio de Janeiro. Anais... Rio de Janeiro: ANPAD, 2011.

DEMO, G.; ROZZETT, K. Customer Relationship Management Scale for the Business-toConsumer market: exploratory and confirmatory validation and models comparison. International Business Research, v. 6, p. 29-42, 2013.

DEMO, G. B2C Market: Development of a CRM Scale. In: GHORBANI, A. (Org.). Marketing in the Cyber Era. Hershey, PA: IGI Global, 2014. p. 85-95.

DESAI, D. B.; KULKARNI, R. V. A Review: application of data Mining tools in CRM for selected banks. International Journal of Computer Science and Information Technologies, v. 4, n. 2, p. 199-201, 2013.

DIGMAN, J. M. Historical antecedents of the five-factor model. IN: COSTA JR, P. T.; WILDIGER, T. A. (Org). Personality disorders and the five-factor model of personality. 2.ed. Washington, DC: American Psychological Association. 2002. p. 17-22.

DINIZ, C. O Mercado do Luxo no Brasil: Tendências e Oportunidades. São Paulo: Seoman, 2012. 
DRENTH, P. J. D. Research and work in organizational psychology: principles and methods. IN: DRENTH, P. J. D. et al. (Org.). Handbook of work and organization psychology, London: Wiley, 1984. p. 13-50.

DUBOIS, B.; CZELLAR, S.; LAURENT, G. Consumer segments based on attitudes toward luxury: Empirical evidence from twenty countries. Marketing Letters, v. 16, n. 2, p. 115$128,2005$.

DURGEE, J. F. Understanding brand personality. Journal of Consumer Marketing, v. 5, n. 3, p. 21-25, 1988.

DYBÅ, T.; DINGSØYR, T. Streingth of evidence in Systematic Reviews in software engineering. Empirical Software Engineering and Measurement (ESEM), v. 8, 2008.

EISEND, M.; STOKBURGER-SAUER, N. E. Measurement Characteristics of Aaker's Brand

Personality Dimensions: Lessons to be Learned from Human Personality Research. Psychology \& Marketing, v. 30, n. 11, p. 950-958, 2013.

ENZMANN, D. RanEigen: A program to determine the parallel analysis criterion for the number of principal components. Applied Psychological Measurement, v. 21, n. 3, p. 232232, 1997.

ERNST, H.; HOYER, W. D.; KRAFFT, M.; KRIEGER, K. Customer relationship management and company performance - the mediating role of new product performance. Journal of the Academy of Marketing Science, v. 39, n. 2, p. 290-306, 2011.

FARIA, L. H. L.; GIULIANI, A. C.; PIZZINATO, N. K.; SPERS, V. R. E. 20 anos de publicações sobre marketing de relacionamento no Brasil: uma análise da produção acadêmica de 1992 a 2012. Revista Brasileira de Marketing, v. 13, n. 1, p. 106-118, 2014. 
FAVA, J. L.; VELICER, W. F. The effects of underextraction in factor and component analyses. Educational and Psychological Measurement, v. 56, n. 6, p. 907-929, 1996.

FENNELL, G. Consumers' Perceptions of the Product: Use Situation. The Journal of Marketing, v. 42, n. 2 p. 38-47, 1978.

FERRANDI, J. M.; MERUNKA, D.; VALETTE-FLORENCE, P.; DE BARNIER, V. Brand personality: how well does a human personality scale apply to brands? Asia Pacific Advances in Consumer Research, v.5, p.53-60, 2002.

FETSCHERIN, M.; TONCAR, M. The effects of the country of brand and the country of manufacturing of automobiles: An experimental study of consumers' brand personality perceptions. International Marketing Review, v. 27, n. 2, p. 164-178, 2010.

FIELD, A. Descobrindo a estatística usando o SPSS. Porto Alegre: Artmed, 2009.

FILLOUX, J. C. A personalidade. São Paulo: Difel, 1983.

FIONDA, A. M.; MOORE, C. M. The anatomy of the luxury fashion brand. Journal of Brand Management, v. 16, n. 5, p. 347-363, 2009.

FLORENCE, P. V.; GUIZANI, H.; MERUNKA, D. The impact of brand personality and sales promotions on brand equity. Journal of Business Research, v. 64, n. 1, p. 24-28, 2011.

FLORENCE, R. V.; BARNIER, V. Towards a micro conception of brand personality: An application for print media brands in a French context. Journal of Business Research, v. 66, n. 7, p. 897-903, 2013.

FOURNIER, S. Consumers and their brands: developing relationship theory in consumer research. Journal of Consumer Research, v. 24, n. 4, p. 343-353, 1998. 
FRAGA, R.; ROCHA, T. V.; JANSEN, C. L. S.; LOFTI, E. Estudo Exploratório sobre o uso das Redes Sociais na Construção do Relacionamento com Clientes. Revista Brasileira de Gestão de Negócios, v. 15, n. 47, p. 262-282, 2013.

FRASER, M. T. D.; GONDIM, S. M. G. Da fala do outro ao texto negociado: discussões sobre a entrevista na pesquisa qualitativa. Paidéia, v. 14, n. 28, p. 139-152, 2004.

FRELING, T. H.; CROSNO, J. L.; HENARD, D. H. Brand personality appeal: conceptualization and empirical validation. Journal of the Academy of Marketing Science, v. 39, n. 3, p. 392-406, 2011.

FRITZ, W.; GÜLOW, W. Luxury Marketing in the Age of Cheap An Exploratory Survey on Consumer Behavior in Online Shopping Clubs. In: WIEDMANN, K.; HENNINGS, N. (Org.). Luxury Marketing: A Challenge for Theory and Practice. Springer Gabler, 2013. p. 187205.

GALÃO, F. P.; BACCARO, T. A.; CHIUSOLI, C. L. Marketing de relacionamento no setor de software: um estudo exploratório. Revista Organizações em Contexto-online, v. 8, n. 16, p. $223-245,2012$.

Galhanone, R. F.; TOLEDO, G. L. Comportamento do Consumidor de Produtos Luxuosos e Sofisticados: Um Estudo Empírico. Anais... XI SEMEAD, p. 1-12, 2008.

GARDNER, B. B.; LEVY, S. J. The product and the brand. Harvard Business Review, v.33, p.33-39, March-April 1955.

GASKELL, G. (2002). Entrevistas individuais e grupais. IN: BAUER, W.; Gaskell, G. (Org.). Pesquisa qualitativa com texto, imagem e som: um manual prático. Petrópolis: Vozes. 2002. p. 64-89.

GEUENS, M.; WEIJTERS, B.; WULF, K. A new measure of brand personality. International Journal of Research in Marketing, v. 26, n. 2, p. 97-107, 2009. 
GIGLIO, E. M. O comportamento do consumidor. 4. ed. São Paulo: Cengage Learning, 2010 .

GODEY, B.; PEDERZOLI, D.; AIELlO, G.; DONVITTO, R.; WIEDMANN, K.; HENNINGS, N. An intercultural comparison of the perception of luxury by Young Consumers. In: WIEDMANN, K.; HENNINGS, N. (Org.). Luxury Marketing: A Challenge for Theory and Practice. Springer Gabler, 2013. p. 57-76.

GODOY, A. S. A pesquisa qualitativa e sua utilização em administração de empresas. Revista de Administração de Empresas, v. 35, n. 4, p. 65-71, 1995.

GOLDBERG, L. R. An alternative "description of personality": the big-five factor structure. Journal of Personality and Social Psychology, v.59, n.6, p.1216-1229, 1990.

GOLDBERG, L. R. Language and individual differences: The search for universals in personality lexicons. Review of personality and social psychology, v. 2, n. 1, p. 141-165, 1981.

GOLDBERG, L. R. The development of markers for the Big-Five factor structure. Psychological Assessment, v. 4, n. 1, p. 26, 1992.

GOLDBERG, L. R. The structure of the phenotypic personality traits. American Psychologist, v.48, n.1, p.26-34, Jan. 1993.

GONÇALVES, D. I. F. Pesquisas de marketing pela internet: as percepções sob a ótica dos entrevistados. Revista de Administração Mackenzie, v. 9, n. 7, p. 70-88, 2008.

GONÇALVES FILHO, C; SALES, J. R.; GOSLING, M. Determinantes da decisão de compra de leite: uma comparação entre marcas tradicionais e marcas próprias. Organizações Rurais \& Agroindustriais, v. 15, n. 3, 2013.

GREENBERG, P. CRM, Customer Relationship Management na velocidade da luz: conquista e lealdade de clientes em tempo real na Internet. Rio de Janeiro: Campus, 2001. p.60, 389-392. 
GRÖNROOS, C. Marketing as promise management: regaining customer management for marketing. Journal of Business \& Industrial Marketing, v. 24, n. 5/6, p. 351-359, 2009.

GUPTA, A.; SAHU, G. P. A literature review and classification of relationship marketing research. International Journal of Customer Relationship Marketing and Management, v. 3, n. 1, p. 56-81, 2012.

HAIR JR, J. F.; BABIN, B.; MONEY, A. H.; SAMOUEL, P. Fundamentos de métodos de pesquisa em administração. São Paulo: Artmed, 2005.

HAIR, J. F.; BLACK, W. C.; BABI, B. J.; ANDERSON, R. E.; TATHAM, R. L. Análise multivariada de dados. 6. ed. Porto Alegre: Bookman, 2009.

HANKINSON, G.; COWKING, P. Branding in action. Maidenhead: McGraw-Hill, 1993.

HANSLIN, K.; RINDELL, A. Consumer-brand relationships in step-down line extensions of luxury and designer brands. Journal of Fashion Marketing and Management, v. 18, n. 2, p. 145-168, 2014.

HAYTON, J. C.; ALLEN, D. G.; SCARPELLO, V. Factor retention decisions in exploratory factor analysis: A tutorial on parallel analysis. Organizational research methods, v. 7, n. 2, p. 191-205, 2004.

HELGESON, J. G.; SUPPHELLEN, M. A conceptual and measurement comparison of selfcongruity and brand personality - The impact of socially desirable responding. International Journal of Market Research, v. 46, n. 2, p. 205-233, 2004.

HERBST, U.; MERZ, M. A. The industrial brand personality scale: Building strong businessto-business brands. Industrial Marketing Management, v. 40, n. 7, p. 1072-1081, 2011.

HOFFMAN, N. P. An examination of the "Sustainable competitive advantage" concept: past, present, and future. Academy of Marketing Science Review, n. 4, p. 1-16, 2000. 
HOOLEY, G. J.; SAUNDERS, J.A.; PIERCY, N. F. Estratégia de Marketing e Posicionamento Competitivo. Terceira edição. São Paulo: Prentice Hall, 2005.

HORN, J. L. A rationale and test for the number of factors in factor analysis. Psychometrika, v. 30, n. 2, p. 179-185, 1965.

HUANG, H. H.; MITCHELL, V. W.; ROSENAUM-ELLIOTT, R. Are consumer and brand personalities the same?. Psychology \& Marketing, v. 29, n. 5, p. 334-349, 2012.

HUANG, J.; XIONG, W. The effect of win-back investment on lost consumers' intention of reinitiating relationship. Frontiers of Business Research in China, v. 4, n. 3, p. 485-497, 2010.

HUANG, M. The influence of relationship marketing investments on customer gratitude in retailing. Journal of Business Research, v. 68, n. 6, p. 1318-1323, 2015.

IGLESIAS, O.; SAUQUET, A.; MONTAÑA, J. The role of corporate culture in relationship marketing, European Journal of Marketing, v. 45, n. 4, p. 631-650, 2011.

KAISER, H. F. An index of factorial simplicity. Psychometrika, v. 39, n. 1, p. 31-36, 1974.

KAPFERER, J. As marcas, capital da empresa. Porto Alegre: Bookman, 2003.

KAPFERER, J.; BASTIEN, V. The specificity of luxury management: Turning marketing upside down. Journal of Brand Management, v. 16, n. 5, p. 311-322, 2009.

KAPLAN, M. D.; YURT, O.; GUNERI, B.; KURTULUS, K. Branding places: applying brand personality concept to cities. European Journal of Marketing, v. 44, n. 9/10, p. 12861304, 2010. 
KAUR, G.; SHARMA, R. D.; MAHAJAN, N. Exploring customer switching intentions through relationship marketing paradigm. International Journal of Bank Marketing, v. 30, n. 4, p. 280-302, 2012.

KELLER, K. L. Building strong brands in a modern marketing communications environment. Journal of Marketing Communications, v. 15, n. 2-3, p. 139-155, 2009.

KELLER, K. L. Strategic brand management: Building, measuring, and managing brand equity. 4.ed. Upper Saddle River, NJ: Prentice Hall, 2012.

KELLER, K. L.; LEHMANN, D. R. Brands and branding: Research findings and future priorities. Marketing Science, v. 25, n. 6, p. 740-759, 2006.

KERLINGER, F. N.; LEE, H. B. Foundations of behavioral research. 5 ed. Independence, KY: Wadsworth Thomson, 2008.

KEVORK, E. K.; VRECHOPOULOS, A. P. CRM literature: conceptual and functional insights by keyword analysis. Marketing Intelligence \& Planning, v. 27, n. 1, p. 48-85, 2009.

KHALAFINEZHAD, R.; LONG, C. S. Customer satisfaction and loyalty: a review in the perspective of CRM. Journal Teknologi (Social Sciences), v. 64, n. 2, p. 61-66, 2013.

KHODAKARAMI, F.; CHAN, Y. E. Exploring the role of customer relationship management (CRM) systems in customer knowledge creation. Information \& Management, v. 51, n. 1, p. 27-42, 2014.

KIM, D.; MAGNINI, V. P.; SINGAL, M. The effects of customers' perceptions of brand personality in casual theme restaurants.International Journal of Hospitality Management, v. 30, n. 2, p. 448-458, 2011.

KIM, D. H.; SUNG, Y. Gucci versus Old Navy: Interplay of brand personality and regulatory focus in advertising persuasion. Psychology \& Marketing, v. 30, n. 12, p. 1076-1087, 2013. 
KIM, J.; BAEK, T. H.; MARTIN, H. J. Dimensions of news media brand personality. Journalism \& Mass Communication Quarterly, v. 87, n. 1, p. 117-134, 2010.

KINKLE, A. O consumidor brasileiro. In: O Luxo: o segredo dos produtos mais desejados do mundo. São Paulo: Editora Barcarolla, 2005. p. 151-153.

KLINE, R. B. Principles and practice of structural equation modeling. 3.ed. New York: The Guilford Press. 2011.

KOTLER, P.; KELlER, K. L. Administração de Marketing. 14. ed., São Paulo: Pearson, Prentice Hall, 2012, 750 p.

KUMAR, V.; JONES, E.; VENKATESAN, R.; LEONE, R. P. Is market orientation a source of sustainable competitive advantage or simply the cost of competing? Journal of Marketing, v. 75, n. 1, p. 16-30, 2011.

LAROS, J. A.; PUENTE-PALACIOS, K. E. Validação cruzada de uma escala de clima organizacional. Estudos de Psicologia, v. 9, n. 1, p. 113-119, 2004.

LEÃO, A. L. M. S.; CAMARGO, T. I.; CAVALCANTI, R. C. T. Como uma onda no mar: a fluida personalidade da Movimento. BBR-Brazilian Business Review, v. 10, n. 3, p. 34-53, 2013.

LEE, J. Relationship between consumer personality and brand personality as self-concept: From the case of Korean automobile brands. Academy of Marketing Studies Journal, v. 13, n. 1, p. 25, 2009.

LEE, J.; BACK, K. Examining antecedents and consequences of brand personality in the upper-upscale business hotel segment. Journal of Travel \& Tourism Marketing, v. 27, n. 2, p. 132-145, 2010. 
LEE, T. M.; JUN, J. K. Contextual perceived value? Investigating the role of contextual marketing for customer relationship management in a mobile commerce context. Business Process Management Journal, v. 13, n. 6, p. 798-814, 2007.

LEE, J.; KIM, S.; PAN, S. The role of relationship marketing investments in customer reciprocity. International Journal of Contemporary Hospitality Management, v. 26, n. 8, p. 1200-1224, 2014.

LEE, Y.; BACK, K.; KIM, J. Family restaurant brand personality and its impact on customer's emotion, satisfaction, and brand loyalty. Journal of Hospitality \& Tourism Research, v. 33, n. 3, p. 305-328, 2009.

LEIBENSTEIN, H. Bandwagon, snob, and Veblen effects in the theory of consumers' demand. The Quarterly Journal of Economics, v. 64, n. 2, p. 183-207, 1950.

LEITE, A. F. J. A consumidora brasileira e o mercado de luxo nacional. São Paulo: Novas Edições Academicas, 2014.

LENDEL, V.; VARMUS, M. proposal of innovative approaChes of relationship marKeting in business. Verslas: teorija ir praktika, n. 1, p. 63-74, 2015.

LEONARD, E.; KATSANIS, L. P. The dimensions of prescription drug brand personality as identified by consumers. Journal of Consumer Marketing, v. 30, n. 7, p. 583-596, 2013.

LIN, R.; CHEN, R.; CHIU, K. K. Customer relationship management and innovation capability: an empirical study. Industrial Management \& Data Systems, v. 110, n. 1, p. 111-133, 2010.

LING-YEE, L. Marketing metrics' usage: Its predictors and implications for customer relationship management. Industrial Marketing Management, v. 40, n. 1, p. 139-148, 2011.

LIPOVETSKY, G.; ROUX, E. O luxo eterno: da idade do sagrado ao tempo das marcas. Editora Companhia das Letras, 2005. 
LOPES, C.; DEMO, G. Desenvolvimento e Validação das Escalas de Relacionamento com Clientes da Cerveja Skol e do Guaraná Antarctica. Encontro de Marketing da ANPAD (EMA), 5. Curitiba. Anais... Curitiba, 2012.

LOUIS, D.; LOMBART, C. Impact of brand personality on three major relational consequences (trust, attachment, and commitment to the brand). Journal of Product \& Brand Management, v. 19, n. 2, p. 114-130, 2010.

LOURENÇO, C. D. S. Cultura Brasileira e Marketing de Relacionamento: Um Estudo Etnográfico no Varejo. Revista Brasileira de Marketing, v. 13, n. 5, p. 47-64, 2014

LOURENÇO, C. D. S.; SETTE, R. S. Relacionamentos de marketing em empresas varejistas: aspectos positivos e negativos. Revista Brasileira de Marketing, v. 12, n. 3, p. 152-178, 2013.

LOVELOCK, C.; WIRTZ, J.; HEMZO, M. A. Marketing de serviços: pessoas, tecnologia e estratégia. 7.ed. São Paulo: Pearson, 2011.

MAEHLE, N.; OTNES, C.; SUPPHELLEN, M. Consumers' perceptions of the dimensions of brand personality. Journal of Consumer Behaviour, v. 10, n. 5, p. 290-303, 2011.

MAGAlHÃES, M. R. A.; CRNKOVIC, L. H.; MORETTI, S. A. Importância do Marketing de relacionamento para a melhoria do atendimento e da vantagem competitiva nos serviços médicos privados. Revista Brasileira de Marketing, v. 8, n. 1, p. 70-92, 2010.

MALAR, L.; NYFFENEGGER, B.; KROHMER, H.; HOYER, W. D. Implementing an intended brand personality: a dyadic perspective. Journal of the Academy of Marketing Science, v. 40, n. 5, p. 728-744, 2012.

MALHOTRA, N. K. Pesquisa de marketing: uma orientação aplicada. Bookman, 2012.

MALIK, M. E.; NAEEM, B. Aaker's Brand Personality Framework: A Critical Commentary. Journal of Basic and Applied Scientific Research, v. 2, n. 15, p. 11992-11996, 2012. 
MANDI, M. A meta-analysis of Customer Relationship Management (CRM) literature. International Journal of Management Cases, v. 12, n. 2, p. 200-200, 2010.

MANLOW, V.; NOBBS, K. Form and function of luxury flagships: An international exploratory study of the meaning of the flagship store for managers and customers. Journal of Fashion Marketing and Management: An International Journal, v. 17, n. 1, p. 49-64, 2013.

MANZINI, E. J. Entrevista semi-estruturada: análise de objetivos e de roteiros. Seminário internacional sobre pesquisa e estudos qualitativos, v. 2, p. 58-59, 2004.

MARTINEAU, P. The personality of the retail store. Harvard Business Review, v.36, 1958.

MATHUR, P.; JAIN, S. P.; MAHESWARAN, D. Consumers' implicit theories about personality influence their brand personality judgments. Journal of Consumer Psychology, v. 22, n. 4, p. 545-557, 2012.

MCCRAE, R. R.; COSTA, P. T. Reinterpreting the Myers-Briggs type indicator from the perspective of the five-factor model of personality. Journal of personality, v. 57, n. 1, p. 17-

40, 1989.

MCF Consultoria e Conhecimento; GfK Custom Research Brasil. O mercado de luxo no Brasil. São Paulo, 2012.

MCKENNA, R. Marketing de relacionamento. Rio de Janeiro: Campus, 1999. 
MENDES, V. L.; PEDRON, C. D. Programas de Fidelidade: um Estudo de Múltiplos Casos em Empresas Portuguesas. Revista Brasileira de Marketing, v. 13, n. 1, p. 60-74, 2014.

MÉNDEZ, J. I. R.; MURPHY, S. A.; PAPADOPOULOS, N. The US brand personality: A Sino perspective. Journal of Business Research, v. 66, n. 8, p. 1028-1034, 2013.

MILAN, G. S.; DE TONI, D. A Construção de um modelo sobre a retenção de clientes e seus antecedentes em um ambiente de serviços. REAd-Revista Eletrônica da Administração, v. 18, n. 2, p. 433-467, 2012.

MILAS, G.; MLAČIĆ, B. Brand personality and human personality: Findings from ratings of familiar Croatian brands. Journal of Business Research, v. 60, n. 6, p. 620-626, 2007.

MISHRA, A.; MISHRA, D. Customer Relationship Management: implementation process perspective. Acta Polytechnica Hungarica, v. 6, n. 4, p. 83-99, 2009.

MOHAMMADHOSSEIN, N.; ZAKARIA, N. H. CRM benefits for customers: literature review (2005-2012). International Journal of Engineering Research and Applications, v. 2, n. 6, p. 1578-1586, 2012.

MÖLLER, J.; HERM, S. Shaping retail brand personality perceptions by bodily experiences. Journal of Retailing, v. 89, n. 4, p. 438-446, 2013.

MONTEIRO, P. R. R.; VEIGA, R. T.; GONÇALVES, C. A. Previsão de comportamentos de consumo usando a personalidade. RAE eletrônica. São Paulo, v. 8, n. 2, Dec. 2009.

MOORE, C. M.; DOHERTY, A. M.; DOYLE, S. A. Flagship stores as a market entry method: the perspective of luxury fashion retailing. European Journal of Marketing, v. 44, n. 1/2, p. 139-161, 2010.

MORGAN, R.M.; HUNT, S.D. The commitment-trust theory of relationship marketing. Journal of Marketing, v. 58, p. 20-38, 1994. 
MOTA, M. O. Measuring moderations: a cross cultural and comparative research in services between brazilians and canadians. REVIEW OF INTERNATIONAL BUSINESS, v. 9, n. 2, p. 39-58, 2014.

MOYA, M. D.; JAIN, R. When tourists are your "friends": Exploring the brand personality of Mexico and Brazil on Facebook. Public Relations Review, v. 39, n. 1, p. 23-29, 2013.

MUNIZ, K. M.; MARCHETTI, R. Dimensões da personalidade de marca: análise da adequação da escala de Aaker (1997) ao contexto brasileiro. XXIX Enanpad. Brasília, 2005.

MUNIZ, K. M.; MARCHETTI, R. Z. Brand personality dimensions in the Brazilian context. BAR, Braz. Adm. Rev., Rio de Janeiro, v. 9, n. 2, Jun 2012.

MYERS, R. H. Classical and modern regression with applications. Belmont, CA: Duxbury Press, 1990.

NARESH, G. Do brand personalities make a difference to consumers? Procedia-Social and Behavioral Sciences, v. 37, p. 31-37, 2012.

NARVER, J. C.; SLATER, S. F. The effect of a market orientation on business profitability. The Journal of Marketing, p. 20-35, 1990.

NGAI, E. W. T. Customer Relationship Management research (1992-2002): na academic literature review and classification. Marketing Intelligence \& Planning, v. 23, n. 6-7, p. 582-605, 2005.

NGAI, E. W. T.; XIU, L.; CHAU, D. C. K. Application of data mining techniques in customer relationship management: a literature review and classification. Expert Systems with Applications, v. 36, p. 2592-2602, 2009.

NOBRE, H.; BECKER, K.; BRITO, C. Brand relationships: a personality-based approach. Journal of Service Science and Management, v. 3, n. 02, p. 206, 2010.

NUENO, J. L.; QUELCH, J. A. The mass marketing of luxury. Business Horizons, v. 41, n. 6, p. 61-68, 1998. 
NUNES, C. H. S. S.; HUTZ. C. S. Construção e validação da escala fatorial de socialização no modelo dos cinco grandes fatores de personalidade. Psicologia: Reflexão e Crítica, v. 20, n. 1, p. 20-25, 2007.

NUnNAlly, J. C.; BERnSteIN, I. H. Psychometric theory. 3.ed. New York: McGrawHill,1994.

NUTTIN, J. A estrutura da personalidade. São Paulo: Livraria Duas Cidades, 1969.

O’MALLEY, L.; TYNAN, C. Relationship marketing in consumer markets-rhetoric or reality? European Journal of Marketing, v. 34, n. 7, p. 797-815, 2000.

ÖZTAYSI, B.; SEZGIN, S.; ÖZOK, A. F. A measurement tool for customer relationship management processes. Industrial Management \& Data Systems, v. 111, n. 6, p. 943-960, 2011.

PARK, J. K.; JOHN, D. R. Capitalizing on brand personalities in advertising: The influence of implicit self-theories on ad appeal effectiveness. Journal of Consumer Psychology, v. 22, n. 3, p. 424-432, 2012.

PARKER, B. T. A comparison of brand personality and brand user-imagery congruence. Journal of Consumer Marketing, v. 26, n. 3, p. 175-184, 2009.

PASQUALI, L. Análise fatorial para pesquisadores. Laboratório de Pesquisa em Avaliação e Medida (LabPAM) - Instituto de Psicologia. Brasília: Universidade de Brasília, 2012.

PAYNE, A. Handbook of CRM: achieving excellence in customer management. Oxford: Elsevier, 2006.

PHAU, I.; PRENDERGAST, G. Consuming luxury brands: the relevance of the "rarity principle'. The Journal of Brand Management, v. 8, n. 2, p. 122-138, 2000. 
PIANARO, L.; MARCONDES, R. C. Estratégias de marketing no mercado de roupas e acessórios de luxo. Revista de Administração FACES, v. 7, n. 1, 2008.

PIANARO, L.; MARCONDES, R. C. Identificação de conceitos, significado e atributos de luxo no mercado de roupas e acessórios. Revista Alcance, v. 17, n. 1, p. 073-083, 2010.

PINTO, M. R.; LARA, J. E. O Marketing de Relacionamento no Mercado Consumidor em uma Perspectiva Experiencial e Simbólica: buscando novas proposições para pesquisas. IV Encontro de Marketing da ANPAD-EMA, 2010.

PLUMMER, J. How personality makes a difference. Journal of Advertising Research, v.24, p.27-31, Dec./Jan. 1985.

PONTES, N. G.; PARENTE, J. G. Personalidade de marca: como se mede. Proceedings of the Encontro Nacional da Associação Nacional de Pós-Graduação e Pesquisa em Administração, 2008.

PORTER, M. E. Towards a dynamic theory of strategy. Strategic Management Journal, v. 12, n. S2, p. 95-117, 1991.

PRINZIE, P.; STAMS, G. J. J., DEKOVIC, M.; REIJNTJES, A. H.; BELSKY, J. The relations between parents' Big Five personality factors and parenting: A meta-analytic review. Journal of Personality and Social Psychology, v. 97, n. 2, p. 351, 2009.

PUPOVAC, L.; ZEHETNER, A.; SUDAREVIC, T. The ways of using CRM systems: the survey of literature. Management Information Systems, v. 7, n. 2, p. 17-23, 2012.

RAFFELT, U.; SCHMITT, B.; MEYER, A. Marketing function and form: How functionalist and experiential architectures affect corporate brand personality. International Journal of Research in Marketing, v. 3, n. 30, p. 201-210, 2013.

RAMPL, L. V.; KENNING, P. Employer brand trust and affect: linking brand personality to employer brand attractiveness. European Journal of Marketing, v. 48, n. 1/2, p. 218-236, 2014. 
REBOLLO, I.; HARRIS, J. R. Genes, ambiente e personalidade. IN: MENDOZA, C. E. F.; COLOM, R. (Org.). Introdução à Psicologia das Diferenças Individuais. Porto Alegre: Artmed. 2006. p. 300-322.

REICHHELD, F. F. Learning from customer defections. Harvard Business School Press. p. 1-22, Mar./Apr. 1996.

REICHHELD, F. F; SASSER JR, W. E. Zero defections - quality comes to services. Harvard Business Review. p. 107-111, Sep./Oct. 1990.

REIJONEN, H.; LAUKKANEN, T. Customer relationship oriented marketing practices in SMEs. Marketing Intelligence \& Planning, v. 28, n. 2, p. 115-136, 2010.

REISE, S. P.; WALLER, N. G.; COMREY, A. L. Factor analysis and scale revision. Psychological assessment, v. 12, n. 3, p. 287, 2000.

Richardson, R. J. Pesquisa social: métodos e técnicas. São Paulo: Atlas, v. 3, 1999.

RIEWOLDT, O. Brandscaping: worlds of experience in retail design. Springer Science \& Business Media, 2002.

ROMANIUK, J.; EHRENBERG, A. Do brands lack personality?. Marketing Theory, v. 12, n. 3, p. 333-339, 2012.

ROZZETT, K.; DEMO, G. Desenvolvimento e validação da Escala de Relacionamento com Clientes (ERC). In: Encontro Nacional de Engenharia de Produção, 30. São Carlos. Anais... Rio de Janeiro: ABEPRO, 2010a.

ROZZETT, K.; DEMO, G. Desenvolvimento e validação da Escala de Relacionamento com Clientes (ERC). Revista Administração de Empresas, v. 50, n. 4, p. 383-395, 2010 b.

ROZZETT, K.; DEMO, G. Escala de Relacionamento com Clientes (ERC): validação fatorial confirmatória por meio da modelagem por equações estruturais. In: Congresso 
Iberoamericano de Psicologia das Organizações e do Trabalho, 2. Florianópolis. Anais... Florianopólis: SBPOT, 2011.

SANTINI, F.; LADEIRA, W. J.; LUBECK, R. M.; ROTTA, C. O impacto da marca na intenção de compra de chocolate ao leite. Revista Competência, v. 5, n. 1, 2014.

SAUCIER, G. Mini-markers: A brief version of Goldberg's unipolar Big-Five markers. Journal of Personality Assessment, v. 63, n. 3, p. 506-516, 1994.

SCHIFFMAN, L. E. O. N. G.; KANUK, L. L. Comportamento do consumidor, v. 6, 2000.

SCHMITT, B. Experiential marketing. Journal of Marketing Management, v. 15, n. 1-3, p. 53-67, 1999.

SCHMITT, B. The consumer psychology of brands. Journal of Consumer Psychology, v. 22, n. 1, p. 7-17, 2012.

SCHULTZ, D. E. SCHULTZ, H. Integrated Marketing Communications - the next generation. New York: McGraw-Hill Books, 2003.

SEMPREBOM, E.; MAFFEZZOLLI, E. C. F.; RIBEIRO, C. M.; PRADO, H. M. A importância da interdependência no relacionamento com marcas. REGE Revista de Gestão, v. 21 , n. 4 , p. $561-577,2014$

SHANK, M.D.; LANGMEYER, L. Does personality influence brand image? The Journal of Psychology, v.128, n.2, p.157, Mar. 1994.

SHETH, J. N.; PARVATIYAR, A. The evolution of relationship marketing. International Business Review, v. 4, n. 4, p. 397-418, 1995.

SHETH, J. N; PARVATIYAR, A. Evolving relationship marketing into a discipline. Journal of Relationship Marketing, v. 1 n. 1, p. 3-16, 2002. 
SHETH, J. N.; PARVATIYAR, A. The domain and conceptual foundations of relationship marketing. In: SHETH, J. N.; PARVATIYAR, A. (Org.). Handbook of relationship marketing. Sage Publications, p. 3-38, 2000.

SILVA, I. B.; NAKANO, T. C. Modelo dos cinco grandes fatores da personalidade: análise de pesquisas. Avaliação Psicológica, v. 10, n. 1, p. 51-62, 2011.

SILVA, L. A.; PIMENTA, R. F.; LOPES, E. L.; MACHADO, E. S. Marketing de Relacionamento em Diferentes Níveis de Contato em Redes Associativistas de Varejo. Revista Brasileira de Marketing, v. 11, n. 2, p. 178-202, 2012.

SIN, L. Y. M.; TSE, A. C. B.; YIM, F. H. K. CRM: conceptualization and scale development. European Journal of Marketing, v. 39, n. 11-12, p. 1264-1290, 2005.

SIRGY, M. J. Self-concept in consumer behavior: a critical review. Journal of Consumer Research, v.9, p.287-300, Dec. 1982.

SISTO, F. F.; OLIVEIRA, A. F. Traços de personalidade e agressividade: um estudo de evidência de validade. Psic, v. 8, n. 1, p. 89-99, 2007.

SOARES, G.; BORTOLUZZO, A. B.; BARROS, H. M. Determinants of the choice of marketing channels by corporate clients: an analysis of the information technology sector. Journal of Information Systems and Technology Management, v. 9, n. 3, p. 515-540, 2012.

SOCH, H.; SANDHU, H. S. Does Customer Relationship Management affect firm performance? Global Business Review, v. 9, n. 2, p. 189-206, 2008.

SOEINI, R. A.; JAFARI, B. CRM performance measurement process. International Journal of Emerging Sciences, v. 2, n. 1, p. 134, 2012. 
SOJAN, S.; RAPHY, S. K.; THOMAS, P. Techniques used in decision support system for CRM - a review. Interational Journal of Information Technology Infrastructure, v. 3, n. 1, p. 9-12, 2014.

SOLOMON, M. R. O comportamento do consumidor: comprando, possuindo e sendo. Porto Alegre: Bookman, 2011.

STEEL, M.; DUBELAAR, C.; EWING, M. T. Developing customised CRM projects: The role of industry norms, organisational context and customer expectations on CRM implementation. Industrial Marketing Management, v. 42, n. 8, p. 1328-1344, 2013.

STREHLAU, S. Marketing do luxo. São Paulo: Cengage Learning, 2008.

STREHLAU, S. Brazil: Luxury and Counterfeits. In: WIEDMANN, K.; HENNINGS, N. (Org.). Luxury Marketing: A Challenge for Theory and Practice. Springer Gabler, 2013. p. $245-260$.

STREHLAU, S.; ARANHA, F. Adaptação e validação da escala de consumo de status (SCS) para uso no contexto brasileiro. Revista de Administração FACES, v. 3, n. 1, 2004.

STREHLAU, S.; FREIRE, O. B. L. Propriedades da escala Brand Luxury Index (BLI) no Brasil. Revista de Administração da Unimep, v. 11, n. 2, p. 82-102, 2013.

SUNG, Y.; TINKHAM, S. F. Brand personality structures in the United States and Korea: Common and culture-specific factors. Journal of Consumer Psychology, v. 15, n. 4, p. 334$350,2005$.

SUNG, Y.; CHOI, S. M.; AHN, H.; SONG, Y. A. Dimensions of Luxury Brand Personality: Scale Development and Validation. Psychology \& Marketing, v. 32, n. 1, p. 121-132, 2015.

SUPPHELLEN, M.; GRONHAUG, K. Building foreign brand personalities in Russia: the moderating effect of consumer ethnocentrism. International Journal of Advertising, v. 22, n. 2, p. 203-226, 2003.

TABACHNICK, B. G.; FIDELL, L. S. Using multivariate statistics. 6.ed. Boston: Pearson Allyn And Bacon, 2013. 
TEECE, D. J.; PISANO, G.; SHUEN, A. Dynamic Capabilities and Strategic Management. Strategic Management Journal, v. 18, n. 7. p. 509-533, 1997.

TRAINOR, K. J.; ANDZULIS, J. M.; RAPP, A.; AGNIHOTRI, R. Social media technology usage and customer relationship performance: A capabilities-based examination of social CRM. Journal of Business Research, v. 67, n. 6, p. 1201-1208, 2014.

TRENTINI, C. M.; HUTZ, C. S.; BANDEIRA, D. R.; TEIXEIRA, M. A. P.; GONÇALVES, M. T. A.; THOMAZONI, A. R. Correlações entre a EFN-escala fatorial de neuroticismo eo IFP-inventário fatorial de personalidade. Avaliação Psicológica, v. 8, n. 2, p. 209-217, 2009.

TRUONG, Y.; MCCOLL, R.; KITCHEN, P. J. New luxury brand positioning and the emergence of masstige brands. Journal of Brand Management, v. 16, n. 5, p. 375-382, 2009.

URDAN, F. T.; URDAN, A. T. O impacto da marca sobre as preferências do consumidor: um experimento com cervejas. Anais do XXV ENANPAD, Campinas, 2001.

TUNGATE, M. Luxury world: the past, present and future of luxury brands. Kogan Page Publishers, 2009.

VASCONCELOS, H.; DEMO, G. Enchant to Retain: an instrumental study about the relationship between Walt Disney World Parks and its Brazilian customers. International Conference on Industrial Engineering and Operations Management, 18. Guimarães, Portugal. Anais... Portugal, 2012.

VAVRA, T. Marketing de relacionamento: como manter a fidelidade de clientes através do marketing de relacionamento. São Paulo: Atlas, 1993.

VERGARA, S. C. Métodos de coleta de dados no campo. São Paulo: Atlas, 2009. 
VIANA, D. A.; CUNHA Jr., M. V. M.; SLONGO, L. A. Medindo o conceito de marketing de relacionamento no contexto brasileiro: a validação de uma escala no setor industrial. In: Encontro da Associação Nacional de Pós-Graduação e Pesquisa em Administração, 29. Brasília. Anais... Brasília: ANPAD, 2005.

VICHROSKI, T. S. F.; PFITSCHER, E. D.; GALLON, A. V.; RICHARTZ, F. O valor real do cliente no processo de crm e a contabilidade: um estudo de caso em empresa do setor de varejo supermercadista. REGE Revista de Gestão, v. 17, n. 4, p. 471-488, 2010.

VIGNERON, F.; JOHNSON, L. W. Measuring perceptions of brand luxury. The Journal of Brand Management, v. 11, n. 6, p. 484-506, 2004.

WAHLBERG, O.; STRANDBERG, C.; SUNDBERG, H.; SANDBERG, K. W. Trends, topics and under-researched areas in CRM research - a literature review. International Journal of Public Information Systems, v. 5, n. 3, p. 191-208, 2009.

WANG, Y.; FENG, H. CRM capability in service industries: conceptualization and scale development. In: Proceedings of 2008 IEEE International Conference on Service Operations and Logistics, and Informatics, Beijing, China, 2008.

WILLIAMS, Alistair; ATWAL, Glyn. The hedonistic consumption of luxury and iconic wines. In: WIEDMANN, K.; HENNINGS, N. (Org.). Luxury Marketing: A Challenge for Theory and Practice. Springer Gabler, 2013. p. 379-393.

WILSON, E. J; VLOSKY, R. P. Partnering relationship activities: building theory from case study research. Journal of Business Research, v. 39 n. 1, p. 59-70, 1997.

WOODRUFF, Robert B. Customer value: the next source for competitive advantage. Journal of the Academy of Marketing Science, vol. 25, n. 2, 1997, p. 139-153.

WU, M.; CHEN, C.; CHANEY, I. Luxury Brands in the Digital Age-the Trust Factor. In: WIEDMANN, K.; HENNINGS, N. (Org.). Luxury Marketing: A Challenge for Theory and Practice. Springer Gabler, 2013. p. 207-219. 
WU, W.; TSAI, C.; FU, C. The Relationships among Internal Marketing, Job Satisfaction, Relationship Marketing, Customer Orientation, and Organizational Performance: An Empirical Study of TFT-LCD Companies in Taiwan. Human Factors and Ergonomics in Manufacturing \& Service Industries, v. 23, n. 5, p. 436-449, 2013.

ZABLAH, A. R.; BELlENGER, D. N.; JOHNSTON, W. J. An evaluation of divergent perspectives on customer relationship management: towards a common understanding of an emerging phenomenon. Industrial Marketing Management, v. 33, p. 475-489, 2004.

ZENTES, J.; MORSCHETT, D.; SCHRAMM-KLEIN, H. Brand personality of retailers-an analysis of its applicability and its effect on store loyalty. The International Review of Retail, Distribution and Consumer Research, v. 18, n. 2, p. 167-184, 2008.

ZULKIFLI, Z.; TAHIR, I. M. Developing and validating Customer Relationship Management (CRM) practices construct. International Journal of Business and Behavioral Sciences, v. 2, n. 1, p. 35-48, 2012. 


\section{Apêndice A - Roteiro de Entrevista}

\begin{tabular}{|c|c|c|}
\hline \multicolumn{2}{|r|}{ Pergunta } & Embasamento Teórico \\
\hline 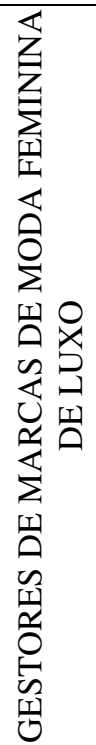 & $\begin{array}{l}\text { Quais aspectos você considera relevantes na } \\
\text { gestão de uma marca de moda feminina de } \\
\text { luxo para que se conquiste a fidelidade dos } \\
\text { clientes, ou seja, para que a cliente estabeleça } \\
\text { um relacionamento de longo prazo com a } \\
\text { marca? }\end{array}$ & $\begin{array}{l}\text { As organizações, em nome da } \\
\text { competitividade, devem estabelecer } \\
\text { relacionamentos de longo prazo ou } \\
\text { relacionamentos lucrativos com os clientes } \\
\text { (DEMO; ROZZETT, 2013). } \\
\text { Uma marca não compõe um objeto passivo } \\
\text { das transações de marketing, mas sim um } \\
\text { elemento ativo, capaz de contribuir para a } \\
\text { construção do relacionamento com o } \\
\text { consumidor (FOURNIER, 1998) }\end{array}$ \\
\hline 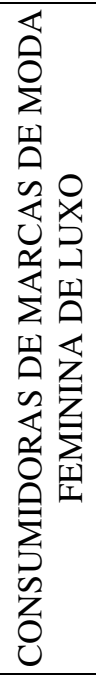 & $\begin{array}{l}\text { O que uma marca de moda feminina de luxo } \\
\text { tem que ter para conquistar a sua fidelidade? }\end{array}$ & $\begin{array}{l}\text { As estratégias de marketing direcionadas aos } \\
\text { produtos de luxo exigem o conhecimento do } \\
\text { que espera o consumidor (ALLÉRĖS, 2000). } \\
\text { O consumidor de luxo tem a expectativa de } \\
\text { ser tratado de forma customizada, como } \\
\text { cliente especial (CASTARÉDE, 2005). } \\
\text { O objetivo do marketing de relacionamento é } \\
\text { a fidelidade do cliente, o que se traduzirá no } \\
\text { estabelecimento de relacionamentos de longo } \\
\text { prazo (ROZZETT; DEMO, 2010). }\end{array}$ \\
\hline
\end{tabular}




\section{Apêndice B - Termo de consentimento para entrevista}

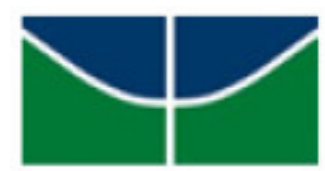

UNIVERSIDADE DE BRASÍLIA

FACULDADE DE ECONOMIA, ADMINISTRAÇÃO E CONTABILIDADE - FACE PROGRAMA DE PÓS-GRADUAÇÃO EM ADMINISTRAÇÃO - PPGA

\section{CONVITE E INFORMAÇÕES PARA PARTICIPAÇÃO EM PESQUISA ACADÊMICA}

Você está sendo convidado (a) a participar de uma pesquisa elaborada pela Professora Doutora Gisela Demo, do Departamento de Administração da Universidade de Brasília, e pela aluna Fernanda Bueno Cardoso Scussel, do Mestrado em Administração, sobre o tema Influência da personalidade de marca no relacionamento com clientes no mercado de moda feminina de luxo.

Gostaríamos de contar com sua colaboração no sentido de responder à pergunta da entrevistadora. O tempo estimado para realização da entrevista é de 10 a 15 minutos.

Precisamos de sua sinceridade nas respostas. Lembre-se de que não há respostas certas ou erradas. Todas são corretas desde que correspondam ao que você pensa. É importante ressaltar que as questões sócio-demográficas buscam apenas caracterizar a amostra da pesquisa. Ademais, os dados desta pesquisa são confidenciais e serão utilizados exclusivamente para fins acadêmicos.

A sua participação nesta pesquisa é voluntária de sorte que você fica livre para interromper a sua participação quando e se achar conveniente, não incorrendo em qualquer prêmio ou prejuízo. Mas, lembre-se: sua participação é essencial para o sucesso desta pesquisa!

Para esclarecer dúvidas e fazer comentários a qualquer momento ou mesmo para conhecer os resultados desta pesquisa, não hesite em contatar fbcardoso@gmail.com Agradecemos sua colaboração! 


\section{TERMO DE CONSENTIMENTO}

$\mathrm{Eu}$, , li e entendi as

informações relativas a esta pesquisa e aceito voluntariamente participar dela como entrevistado.

Autorizo o uso de gravador durante a entrevista ( )

Não autorizo o uso de gravador durante a entrevista ( )

ASSINATURA

DATA

\section{QUESTÕES SOCIO-DEMOGRÁFICAS:}

1. Qual sua idade?

2. Sexo:

( ) Masculino

( ) Feminino

3. Por favor, indique sua escolaridade completa:

( ) Ensino Fundamental

( ) Ensino Médio

( ) Ensino Superior

( ) Mestre

( ) Doutor 


\title{
Apêndice C - Instrumento de Pesquisa (Estudo Quantitativo)
}

\author{
$\psi$ \\ UNIVERSIDADE DE BRASÍLIA \\ PROGRAMA DE PÓS-GRADUAÇÃO EM ADMINISTRAÇÃO - PPGA
}

\section{PESQUISA SOBRE MARCAS DE MODA FEMININA DE LUXO}

Você está sendo convidada a participar de uma pesquisa elaborada pela aluna Fernanda Bueno Cardoso Scussel, do curso de Mestrado em Administração da Universidade de Brasília, sob a orientação da Professora Dra. Gisela Demo, sobre A Influência da Personalidade de Marca no Relacionamento com Clientes de Marcas de Moda Feminina de Luxo. Assim, você só poderá participar da pesquisa se for cliente de alguma marca de moda feminina de luxo e tiver 18 anos ou mais.

Gostaríamos de contar com sua colaboração no sentido de responder ao questionário objetivo a seguir com as devidas orientações para preenchimento. O tempo estimado para responder às questões é de 10 minutos. Precisamos de sua sinceridade nas respostas. Lembrese de que não há respostas certas ou erradas. Todas são corretas desde que correspondam ao que você pensa. É importante ressaltar que as questões sóciodemográficas ao fim do questionário buscam apenas caracterizar a amostra da pesquisa. Ademais, os dados desta pesquisa são confidenciais e serão utilizados exclusivamente para fins acadêmicos.

A sua participação nesta pesquisa é voluntária, de sorte que você fica livre para interromper a sua participação quando e se achar conveniente, não incorrendo em qualquer prêmio ou prejuízo. Mas, lembre-se: sua participação é essencial para o sucesso desta pesquisa. Por gentileza, evite deixar itens em branco, há opções de resposta para quem preferir não se manifestar (exs: não se aplica; não concordo nem discordo).

Agradecemos sua colaboração!

\section{TERMO DE CONSENTIMENTO}

$\mathrm{Eu}$, li e entendi as informações relativas a esta pesquisa e aceito voluntariamente participar dela como entrevistado. 
Por favor, insira o nome de uma marca de moda feminina de luxo da qual seja cliente:

\section{Parte I - Personalidade de Marca}

Para os itens a seguir, veja o quanto a palavra descreve totalmente, descreve parcialmente (pontos do meio da escala) ou não descreve a marca que você está avaliando. Depois, marque um "X" no grau de sua concordância ou discordância. A escala varia de 'essa característica não descreve em nada a marca' a 'essa característica descreve totalmente a marca'.

Essa característica não descreve

Essa característica

em nada a marca descreve totalmente

\begin{tabular}{|c|l|c|c|c|c|c|c|c|c|c|c|}
\hline \multicolumn{10}{|c}{ m nada marca } \\
\hline 3 & 1 & 2 & 3 & 4 & 5 & 6 & 7 & 8 & 9 & 10 \\
\hline 4 & Responsável & 1 & 2 & 3 & 4 & 5 & 6 & 7 & 8 & 9 & 10 \\
\hline 5 & Cegura & 1 & 2 & 3 & 4 & 5 & 6 & 7 & 8 & 9 & 10 \\
\hline 6 & Confiável & 1 & 2 & 3 & 4 & 5 & 6 & 7 & 8 & 9 & 10 \\
\hline 7 & Correta & 1 & 2 & 3 & 4 & 5 & 6 & 7 & 8 & 9 & 10 \\
\hline 8 & Respeitável & 1 & 2 & 3 & 4 & 5 & 6 & 7 & 8 & 9 & 10 \\
\hline 9 & Leal & 1 & 2 & 3 & 4 & 5 & 6 & 7 & 8 & 9 & 10 \\
\hline 10 & Consistente & 1 & 2 & 3 & 4 & 5 & 6 & 7 & 8 & 9 & 10 \\
\hline 11 & Legal & 1 & 2 & 3 & 4 & 5 & 6 & 7 & 8 & 9 & 10 \\
\hline 12 & Feliz & 1 & 2 & 3 & 4 & 5 & 6 & 7 & 8 & 9 & 10 \\
\hline 13 & Festiva & 1 & 2 & 3 & 4 & 5 & 6 & 7 & 8 & 9 & 10 \\
\hline 14 & Extrovertida & 1 & 2 & 3 & 4 & 5 & 6 & 7 & 8 & 9 & 10 \\
\hline 15 & Divertida & 1 & 2 & 3 & 4 & 5 & 6 & 7 & 8 & 9 & 10 \\
\hline 16 & Bem-humorada & 1 & 2 & 3 & 4 & 5 & 6 & 7 & 8 & 9 & 10 \\
\hline 17 & Brincalhona & 1 & 2 & 3 & 4 & 5 & 6 & 7 & 8 & 9 & 10 \\
\hline 18 & Moderna & 1 & 2 & 3 & 4 & 5 & 6 & 7 & 8 & 9 & 10 \\
\hline 19 & Ousada & 1 & 2 & 3 & 4 & 5 & 6 & 7 & 8 & 9 & 10 \\
\hline 20 & Criativa & 1 & 2 & 3 & 4 & 5 & 6 & 7 & 8 & 9 & 10 \\
\hline 21 & Atualizada & 1 & 2 & 3 & 4 & 5 & 6 & 7 & 8 & 9 & 10 \\
\hline 22 & Chique & 1 & 2 & 3 & 4 & 5 & 6 & 7 & 8 & 9 & 10 \\
\hline 23 & Elegante & 1 & 2 & 3 & 4 & 5 & 6 & 7 & 8 & 9 & 10 \\
\hline 24 & Alta-classe & 1 & 2 & 3 & 4 & 5 & 6 & 7 & 8 & 9 & 10 \\
\hline 25 & Sofisticada & 1 & 2 & 3 & 4 & 5 & 6 & 7 & 8 & 9 & 10 \\
\hline 26 & Glamorosa & 1 & 2 & 3 & 4 & 5 & 6 & 7 & 8 & 9 & 10 \\
\hline 27 & Romântica & 1 & 2 & 3 & 4 & 5 & 6 & 7 & 8 & 9 & 10 \\
\hline 28 & Delicada & 1 & 2 & 3 & 4 & 5 & 6 & 7 & 8 & 9 & 10 \\
\hline 29 & Sensitiva & 1 & 2 & 3 & 4 & 5 & 6 & 7 & 8 & 9 & 10 \\
\hline
\end{tabular}




\section{Parte II - Marketing de Relacionamento}

Avalie cada uma das afirmativas seguintes de acordo com a escala abaixo, indicando na coluna à direita das questões o quanto você concorda ou discorda de cada afirmativa. Escolha o número (de 1 a 5) que melhor representa sua percepção quanto ao seu relacionamento com a marca de moda feminina escolhida. Por favor, não deixe nenhum item em branco, caso esteja em dúvida ou prefira não se manifestar, escolha o número 3 , ponto neutro da escala.

\begin{tabular}{|ccccc|}
\hline 1 & 2 & $\mathbf{3}$ & $\mathbf{4}$ & $\mathbf{5}$ \\
\hline Discordo & Discordo & Não concordo & Concordo & Concordo \\
Totalmente & & nem discordo/ & & Totalmente \\
& & Não se aplica & & \\
\hline
\end{tabular}

\begin{tabular}{|l|l|l|}
\hline 32 & Esta marca merece minha confiança. & \\
\hline $3_{3}$ & Eu recomendo esta marca a amigos e familiares. & \\
\hline 34 & Eu me sinto uma cliente importante para essa marca. & \\
\hline & $\begin{array}{l}\text { Minhas experiências de compra com esta marca superam minhas } \\
\text { expectativas. }\end{array}$ & \\
\hline${ }_{36}$ & Eu me identifico com esta marca. & \\
\hline${ }_{37}$ & Esta marca me trata com respeito. & \\
\hline${ }_{38}$ & Os preços dos produtos desta marca são justos (relação custo/benefício). & \\
\hline${ }_{39}$ & Esta marca procura conhecer minhas preferências. & \\
\hline${ }_{40}$ & Esta marca recompensa minha fidelidade. & \\
\hline 41 & Estou disposto a comprar outros produtos desta marca. & \\
\hline 42 & Esta marca é rápida na solução de problemas. & \\
\hline 43 & Os produtos vendidos por esta marca têm qualidade. & \\
\hline 44 & Esta marca cumpre o que promete em suas vendas. & \\
\hline 45 & Esta marca me convida para eventos. & \\
\hline 46 & As minhas reclamações e sugestões são consideradas por essa marca. & \\
\hline 47 & Essa marca possui lojas em diferentes cidades e países. & \\
\hline & Esta marca utiliza diferentes canais de comunicação (ex: telefone, internet, & \\
\hline 48 & aplicativos para celular) para oferecer conveniência às clientes. & \\
\hline 49 & Esta marca é a melhor opção comparada às suas concorrentes no mercado. & \\
\hline 50 & Esta marca é reconhecida no mercado como uma marca de luxo. & \\
\hline 51 & Esta marca tem credibilidade no mercado. & \\
\hline 52 & Esta marca permite que eu experimente/toque os produtos expostos na loja. & \\
\hline 53 & As lojas desta marca estão localizadas em endereços e/ou bairros nobres. & \\
\hline${ }_{54}$ & Os ambientes das lojas desta marca são sofisticados. & \\
\hline${ }_{55}$ & A publicidade realizada por essa marca condiz com o que ela realmente & \\
\hline & & \\
\hline
\end{tabular}




\begin{tabular}{|l|l|l|} 
& oferece. & \\
\hline${ }_{56}$ & Sou bem recepcionada quando entro em uma loja desta marca. & \\
\hline${ }_{57}$ & Eu posso personalizar os produtos desta marca com minhas preferências. & \\
\hline${ }_{58}$ & Os vendedores desta marca são prestativos e atenciosos. & \\
\hline${ }_{59}$ & $\begin{array}{l}\text { As lojas desta marca possuem vendedores que falam diferentes idiomas } \\
\text { para atender aos clientes estrangeiros. }\end{array}$ & \\
\hline${ }_{60}$ & Eu sou atendido pelo (a) vendedor (a) da minha preferência. & \\
\hline & $\begin{array}{l}\text { Esta marca utiliza meu canal de comunicação preferido (ex: telefone, } \\
\text { correspondência, e-mail, mensagens via celular) para se comunicar } \\
\text { comigo. }\end{array}$ & \\
\hline${ }_{62}$ & Esta marca me oferece brindes, presentes e/ou cortesias. & \\
\hline & $\begin{array}{l}\text { Esta marca procura conhecer minha opinião a respeito dos produtos } \\
\text { adquiridos. }\end{array}$ & \\
\hline${ }_{64}$ & Esta marca me oferece atendimento personalizado/exclusivo. & \\
\hline${ }_{65}$ & Esta marca me oferece garantia dos produtos. & \\
\hline 66 & Há procedimentos claros de devolução e/ou troca de produtos desta marca. & \\
\hline & $\begin{array}{l}\text { Esta marca se faz presente em momentos importantes da minha vida (ex: } \\
\text { mensagens de parabéns, descontos ou presentes no mês ou dia do } \\
\text { aniversário). }\end{array}$ & \\
\hline${ }_{67}$ & $\begin{array}{l}\text { Esta marca envolve as clientes trabalhando suas sensações (ex: aromas, } \\
\text { luzes, cores, músicas). }\end{array}$ & \\
\hline${ }_{68}$ & $\begin{array}{l}\text { Esta marca me oferece atendimento ou serviços de entrega domiciliar, caso } \\
\text { solicitado. }\end{array}$ & \\
\hline${ }_{70}$ & Os vendedores desta marca conhecem bem os produtos que vendem. & \\
\hline${ }_{71}$ & Os produtos desta marca dão prestígio a quem os usa. & \\
\hline
\end{tabular}

\section{Parte III - Informações Sóciodemográficas}

\section{Qual sua idade?}

Por favor, identifique sua escolaridade: (curso completo)

Ensino Fundamental

Ensino Médio

Ensino Superior

Pós-graduação/MBA

Mestrado

Doutorado

\section{Há quanto tempo é cliente desta marca?}

Menos de 1 ano

Entre 1 e 5 anos

Entre 5 e 10 anos

Mais de 10 anos

Com que frequência você compra produtos desta marca?

Mensalmente

Anualmente 
Periodicamente, com intervalos maiores que 1 ano

Raramente 